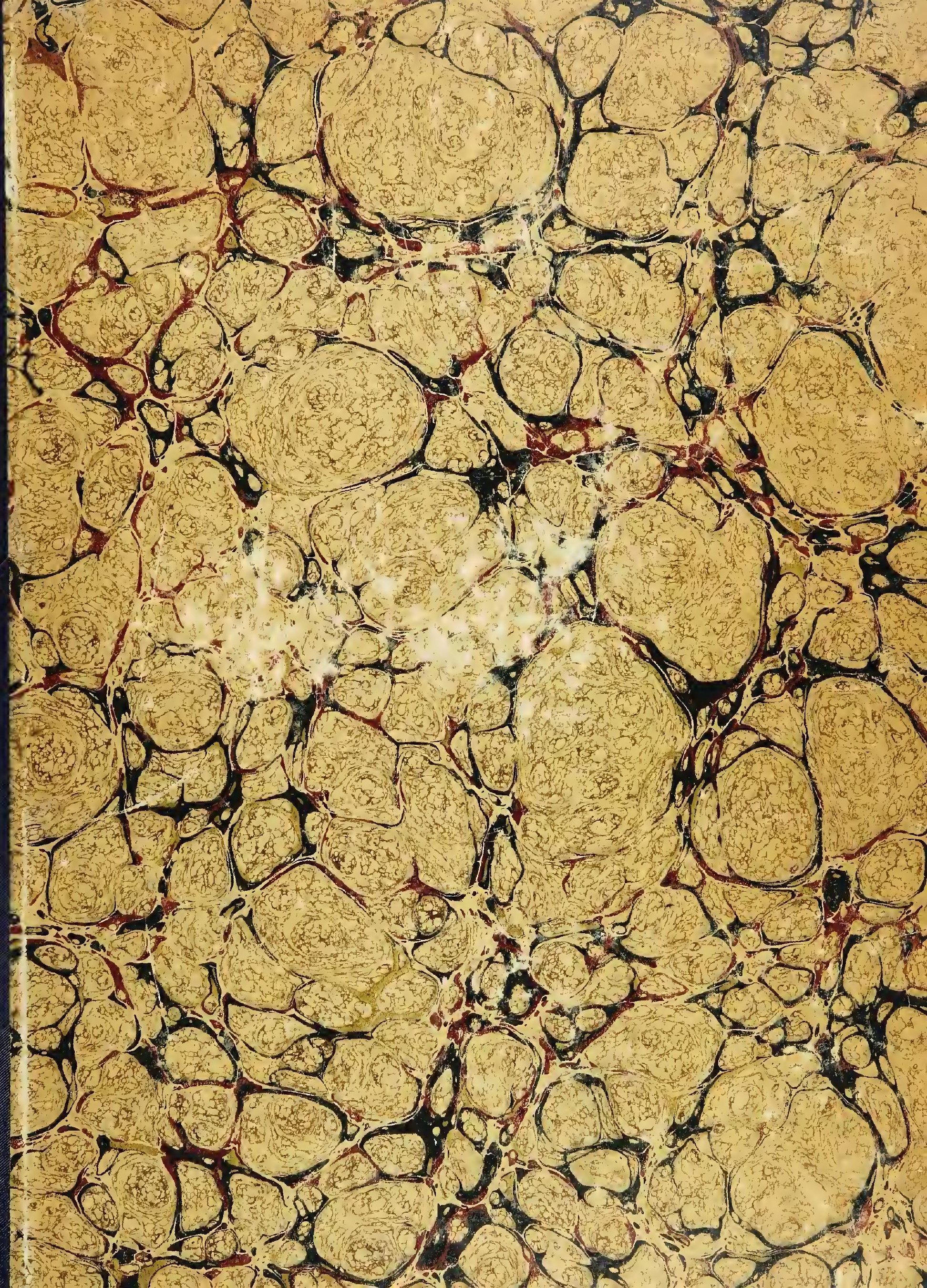




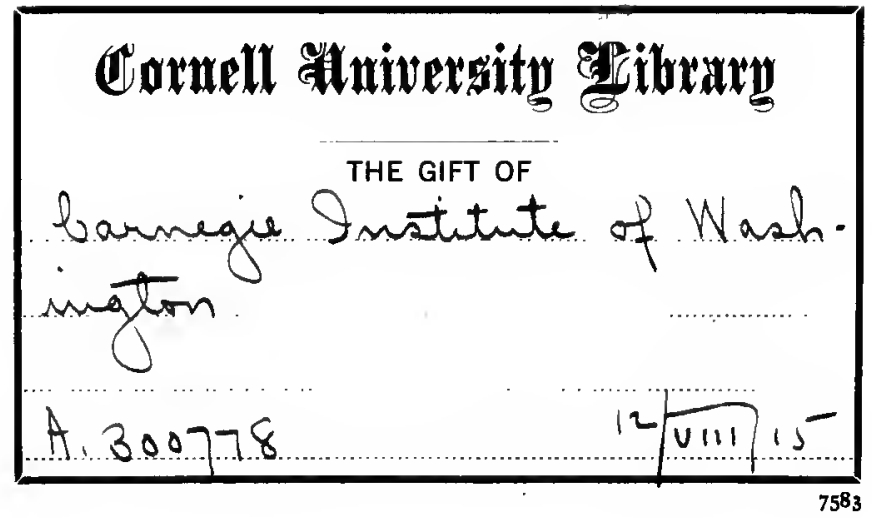




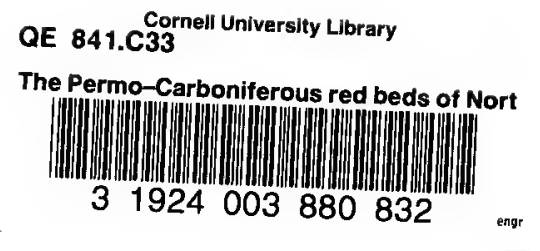




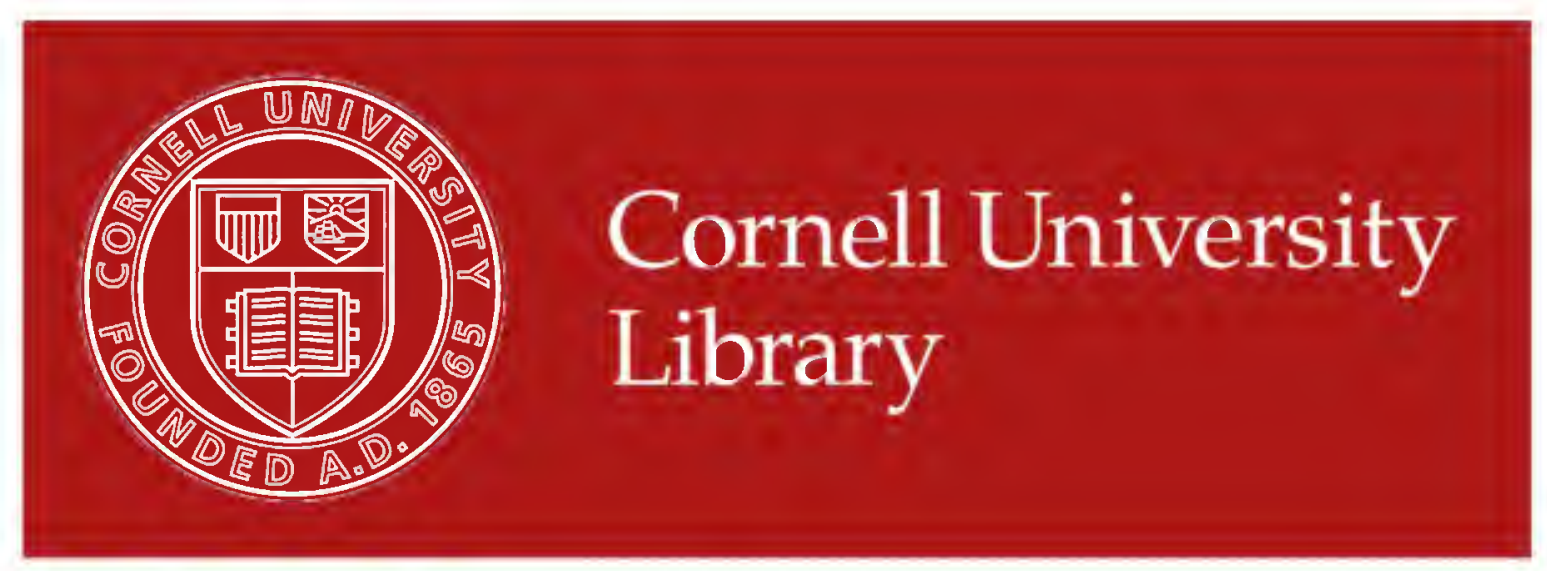

\section{The original of this book is in the Cornell University Library.}

There are no known copyright restrictions in the United States on the use of the text.

http://www.archive.org/details/cu31924003880832 





\title{
THE PERMO-CARBONIFEROUS RED BEDS OF NORTH AMERICA AND THEIR VERTEBRATE FAUNA
}

\author{
By \\ E. C. CASE \\ Professor of Historical Geology and Paleontology in the University of Michigan
}

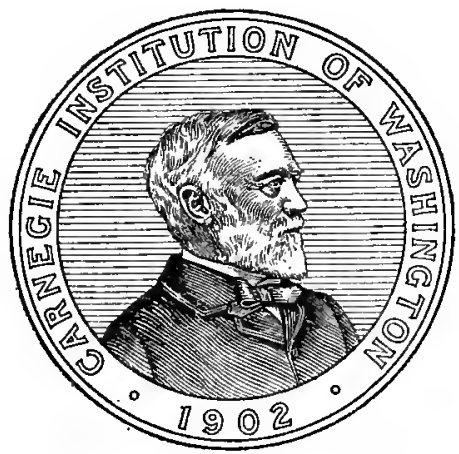

WASHINGTON, D. C.

PUBlished BY THE CARNEGIE INSTITUTION OF WASHINGTON

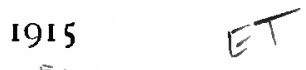

E.V. 


\section{A. $30017 \%$ \\ CARXEAL INSTITUTION OF WASHINGTUN \\ Publigation No. $20 \%$}

\section{Copios of this Beck \\ were first inued \\ JUN 251915}

PIEESS OF J. 13. LIPPINCOTT COMPANY I'IIILADELPHIA 


\section{CONTENTS}

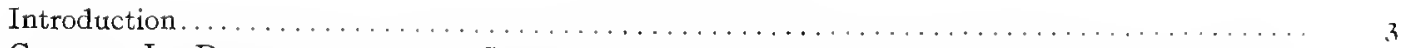

Chapter I.-Description of the Southern Portion of the Plains Province........... 5

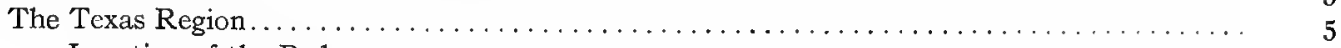

Location of the Beds........................... 5

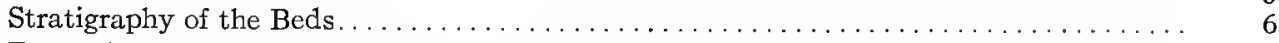

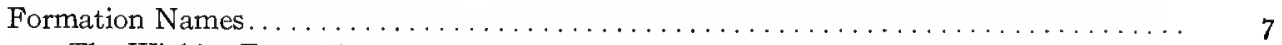

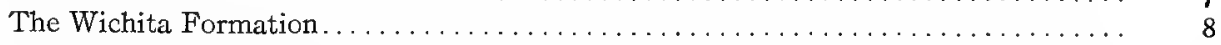

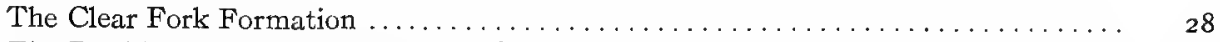

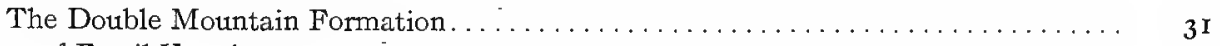

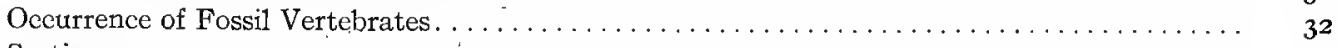

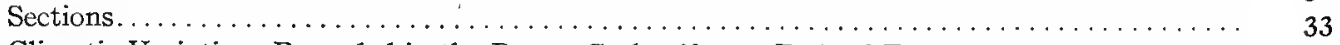

Climatic Variations Recorded in the Permo-Carboniferous Beds of Texas............ 42

Evidence of Climatic Conditions in Wichita time..................... 42

Evidence of Climatic Conditions in Clear Fork time..................... 45

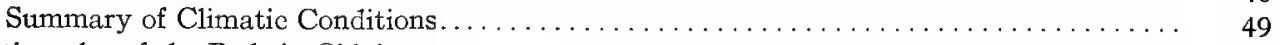

Stratigraphy of the Beds in Oklahoma . . . . . . . . . . . . . . . .

Stratigraphy of the Beds in Kansas............................. 56

Extension of the Red Beds beyond the Limits of Vertebrate Fossils in the Southern Portion of

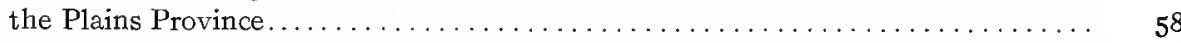

Evidence of a Barrier, or the Interruption of the Red Beds, in the Southwest . . . . . . . . 60

Chapter II.-Description of the Northern Portion of the Plains Province and the Eastern

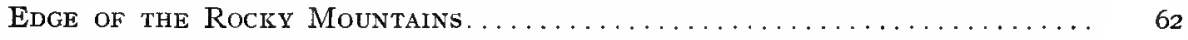

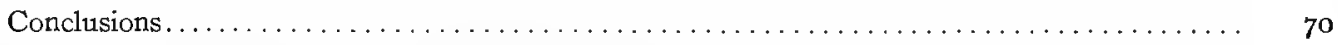

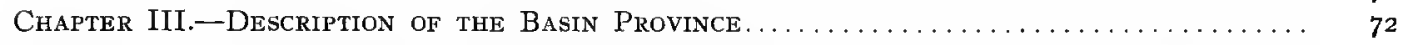

Chapter IV.-Description of the Permo-Carboniferous Beds in the Eastern Portion of

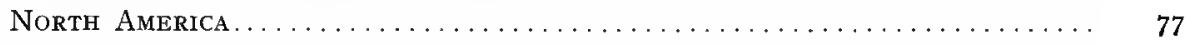

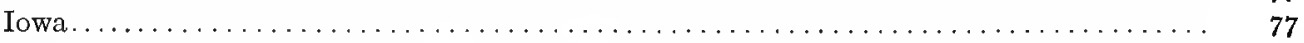

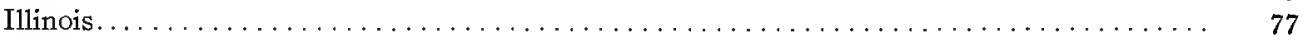

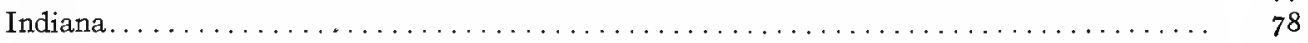

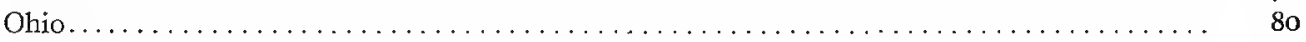

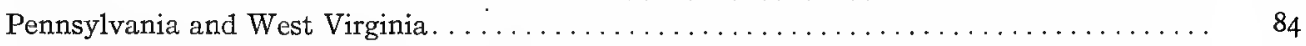

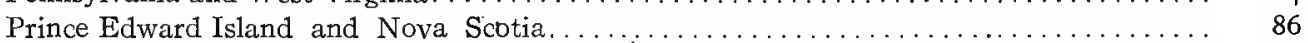

Chapter V.-Geography of North America at the close of the Permo-Carboniferous.. 88

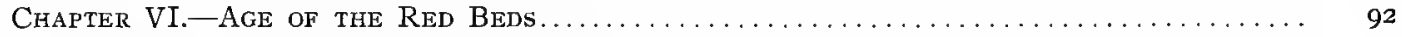

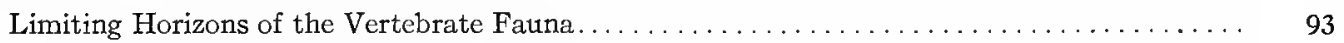

Table showing the Permo-Carboniferous Fauna, as far as known, with the Geographical and Geological Distribution. .

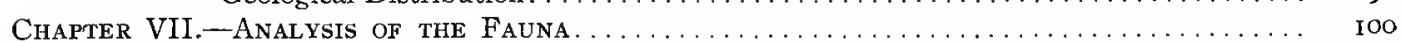

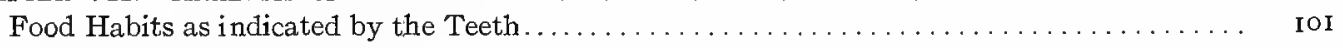

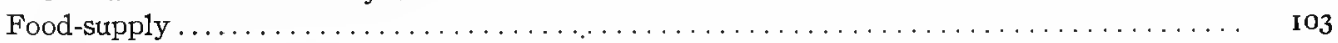

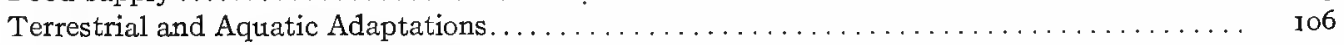

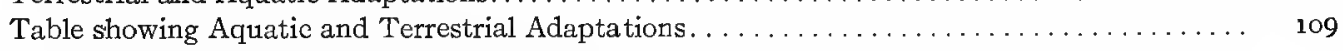

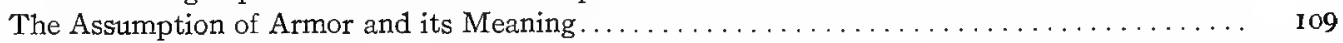

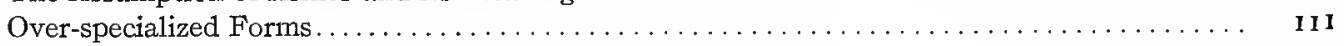

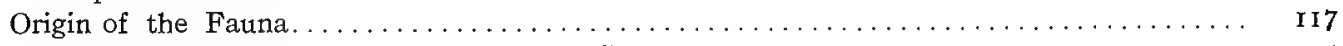

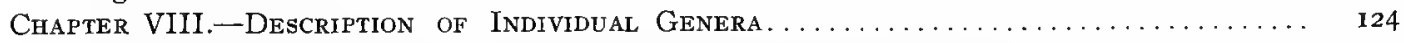

Restoration of the Region and the Environment in which the Animals lived.......... I47

Table showing the Forms in Texas and New Mexico which show Parallelism or Relationship in

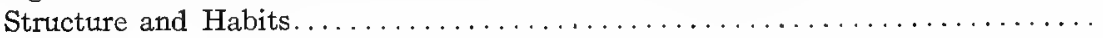

Chapter IX.-Relation of North America to the Other Continents in Permo-Carbonifer-

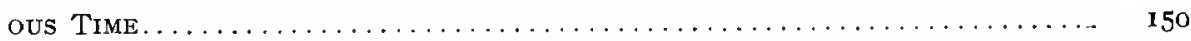

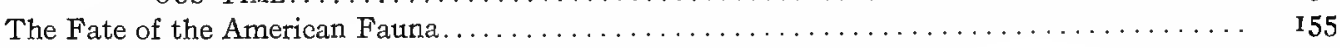

Appendix. 一The Brier Creek Bone-bed and its Fauna $\ldots \ldots \ldots \ldots \ldots \ldots \ldots \ldots \ldots \ldots \ldots$ I57 



\title{
THE PERMO-CARBONIFEROUS RED BEDS OF NORTH AMERICA AND THEIR VERTEBRATE FAUNA
}

\author{
By \\ E. C. CASE \\ Professor of Historical Geology and Paleontology in the University of Michigan
}




\section{INTRODUCTION.}

The present paper is the fifth* in the series by the author on the vertebrate fauna of the Permo-Carboniferous beds of North America, published by the Carnegie Institution of Washington, including the volume on the Permo-Carboniferous vertebrates of New Mexico by E. C. Case, and S. W. Williston of the University of Chicago. The object of this work is to summarize, as far as possible, the information gained concerning the vertebrate fauna; the influence of the environment in its history; its origin, evolution and extinction or disappearance from North America; its range over the continent, and its possible migrations. In order to make clear the conditions under which the animals lived and developed it has been necessary to introduce a somewhat extended description of the beds in which they occur and to assemble all possible information relative to the character and the source of the sediments, the climatic conditions, and so forth. For the amount of this material and the abundant quotations included the author may perhaps be pardoned, as it has been his effort to include all possible pertinent evidence in the knowledge that others may draw very different conclusions from the same observations.

With the exact age of the beds the author has not troubled himself in this publication; the solution of this vexed question must require distinct treatment and the best efforts of men far better qualified than he is at present to evaluate the evidence of invertebrate fossils. Suffice it to say that from the evidence furnished in detail in the body of this paper he is convinced that the stage of evolution of the vertebrates, their stratigraphic position, and the accompanying invertebrates indicate that the beds are of PermoCarboniferous age, and this conclusion is reached with a full knowledge that the evidence from fossil plants is in favor of the Permian age of the beds. Conflicting evidence of age from plant and animal fossils is no new thing in stratigraphy, and we must wait until a more complete knowledge can reconcile the different interpretations.

That our knowledge of the fauna is still incomplete is apparent to every one who has paid any attention to the study or exploration of the beds, but it has advanced so far that it is not probable that many entirely new things will be found, and a summary of the known fauna and an account of

* I. Revision of the Pelycosauria of North America. Carnegie Inst. of Wash., Pub. 55, 1907.

2. Revision of the Cotylosauria of North America. Carnegie Inst. of Wash., Pub. I45, I9I I.

3. Revision of the Amphibia and Pisces of North America; with a Description of Permian Insects,

by E. H. Sellards; and a Discussion of the Fossil Fishes, by Louis Hussakof. Carnegie Inst. of Wash., Pub. 146, I9II.

4. Permo-Carboniferous Vertebrates from New Mexico, by E. C. Case, S. W. Williston, and M. G. Mehl. Carnegie Inst. of Wash., Pub. I8I, I9 I3. 
the conditions under which they lived and developed may properly be offered as a part of the series and for the same purpose-to form a basis for future work.

From evidence furnished in the body of this work the author is convinced that there were two large areas of Red Bed deposition in western North America near the close of the Paleozoic. One may be referred to as the Plains Province; it included the western portions of Texas, Oklahoma, Kansas, Nebraska, and southwestern South Dakota and the portions of Wyoming, Colorado, and New Mexico east of the Rocky Mountain Front Ranges; that this area extended far to the north, even into Canada, there is some evidence, but the limits of the northern portion can not yet be stated. The other area, referred to as the Basin Province, can not be so clearly outlined as the first, but from the combined evidence of vertebrate and invertebrate fossils it is apparent that there was an area of Red Bed deposition west of the Rocky Mountain Front ranges, extending from the Colorado Canyon through western New Mexico, western Colorado, Utah, and Wyoming. Whether this area also extended farther to the north is not known. The extent of these areas is shown on the map opposite page 88 , plate 4 .

It is not the intention of the author to maintain that deposition in the two areas was contemporaneous; in fact, there is some reason to believe that the western area received its deposits somewhat earlier than the eastern, but this matter also remains to be decided.

Vertebrate fossils of Permo-Carboniferous age have been found in five localities in North America: (I) In an area in Texas, Oklahoma, and Kansas, a portion of the Plains Province; (2) in north-central New Mexico, a portion of the Basin Province; (3) in east-central Illinois; (4) in western Pennsylvania; (5) in Prince Edward Island, Canada.

The author desires to repeat the thanks, expressed in previous publications, to the Carnegic Institution of Washington and its officers, for the aid and encouragement which has enabled him to carry thus far a research, which has involved no small amount of time and labor. 


\section{CHAPTER I. \\ DESCRIPTION OF THE SOUTHERN PORTION OF THE PLAINS PROVINCE. \\ THE TEXAS REGION.}

LOCATION OF THE BEDS. ${ }^{a}$

The region most prolific in vertebrate fossils of Permo-Carboniferous age lies in north-central Texas, mostly in Wichita, Archer, Wilbarger, and Baylor Counties, but the relatively abundant finds of fossils in this area are, in part at least, due to the fortunate exposure of large areas of "bad lands" devoid of vegetation and dissected by erosion. The same beds extend over a much larger area, being exposed far to the south in Texas and to the north in Oklahoma, with evidence that they extend north even to the Black Hills and west to the Rocky Mountains. Gould has given the following outline of the portion of the beds which have yielded vertebrate remains: ${ }^{b}$

"The most northern exposure of the beds, so far as known to the writer, is near Arlington, a few miles south of Hutchinson, Reno County, Kansas. The eastern border of the outcrop of the Red Beds in Kansas and Oklahoma is a crescentshaped line running southeast from near Hutchinson and east of Kingman, Kansas, crossing the Kansas-Oklahoma line at Caldwell, then trending southeast near Nardin, Tonkawa, and Red Rock, cutting diagonally across the strike of the Pennsylvanian limestones and shale through the eastern part of Payne and Lincoln Counties to the western part of the Creek and Seminole Nations. Here the line swings to the southwest, and continues through the Chickasaw Nation to the vicinity of Davis, Indian Territory, passes around the western end of the Arbuckle Mountains, crossing Red River 35 miles west of Gainesville, Texas, and, as stated by Adams, cuts diagonally across the strike of the Pennsylvanian limestones in Archer, Young, and Throckmorton Counties, Texas."

Beyond Throckmorton County the Red Beds reckoned as PermoCarboniferous may be traced, as described by Cummins, generally southwest through western Shackelford County and eastern Jones County, following the course of the Clear Fork of the Brazos River, thence south in extreme western Callahan County to near its middle line; thence southwest across the southeast corner of Taylor County, and then generally south through central Runnels County or a little east and south through Concho County to beyond the Concho River. Here the line turns west beneath the outcrop of the Cretaceous to the edge of the Llano Estacado, which it follows north to the latitude of Amarillo; north of Amarillo it appears in the breaks of the Canadian near Plemons, in Hutchinson County, and possibly

a Compare map opposite page 6, plate $I$.

b Gould, U. S. Geological Survey, Water Supply and Irrigation Paper No. 148, p. 37. 
in Oldham County, Texas, and again in Beaver County, Oklahoma. From here it appears at intervals from beneath the Tertiary, curving through Clark, Comanche, Barber, Kingman, and Harper Counties, Kansas.

STRATIGRAPHY OF THE BEDS IN TEXAS.

The Permo-Carboniferous beds of Texas were divided by Cummins ${ }^{2}$ into three formations: the Double Mountain, the Clear Fork, and the Wichita. Schuchert ${ }^{\mathrm{b}}$ unites these in the Brazos group, which is equivalent to the Oklahoman of Keyes. These beds can be directly correlated with certain beds in Oklahoma, as shown by the following from Gould:

"From the best available information, it seems probable that the Wichita beds are approximately the equivalent of those near Chandler, the Clear Fork beds include about the same rocks as the Enid, Blaine, and Woodward formations, and that the Double Mountain beds are practically the same as the Greer and the Quartermaster formations."

With the ideas expressed by Gould in this quotation, the author is in perfect accord, as the result of his work during several years in Texas and Oklahoma, and especially from his study of the formations mentioned during the summer of I9I 2.

The Wichita and Clear Fork in Texas and the Enid in Oklahoma are the only formations in which vertebrate fossils have been found. The Wichita formation lies in an area between the east line described above and a line running from the Red River southwest just east of Holliday, in Archer County, and south to the northwest corner of Young County, where it crosses the west line and apparently continues a little west of south to where it joins the edge of the Carboniferous. The line between the Wichita and the Clear Fork is very difficult to determine at this point (plate I). The western limit of the Clear Fork formation follows a line approximately through or slightly west of Haskell, north to Seymour in Baylor County, and north to the Red River, which it strikes just east of the west line of Wilbarger County. This line is close to the one originally drawn by Cummins. ${ }^{\circledR}$ The Double Mountain formation includes the western portion of the Red Beds in Texas, between the western edge of the Clear Fork and the eastern face of the Llano Estacado.

If, as believed by Gould and the author, the Enid, Blaine, and Woodward formations in Oklahoma are the equivalent of the Clear Fork, the western limit of the possible bone-bearing beds in that State runs northwest through Caddo, Washita, Custer, Dewey, Woodward, and Harper Counties to the Kansas line, as indicated in Gould's map. ${ }^{e}$ To this must be added, in the opinion of the author, all the region marked by Gould as "Red Beds of

a Cummins, First Annual Report Geological Survey of Texas, I889, p. I 86.

b Schuchert, Paleogeography of North America, Bull. Am. Geol. Soc., vol. 20, p. 558.

- Gould, U. S. Gcological Survey, Water Supply and Irrigation Paper No. 154, p. I7.

d Cummins, 2d Annutal Report, Gcol. Surv. Tcxas, map opposite p. 522.

- Gould, U. S. Geological Survey, Water Supply and Irrigation Paper No. 148. 



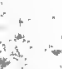

2

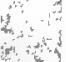


uncertain relationship" surrounding the Wichita Mountains and occupying all of Tillman County and parts of Comanche, Jackson, Greer, Kiowa, Caddo, Washita, and Cotton Counties. Vertebrates have been found only in the Enid formation, the portion of the Red Beds to the east, reckoned as equivalent to the Wichita, not having yielded vertebrates, and the Blaine and Woodward being, so far as known, equally barren. All the well-known fossils from Oklahoma came from Grant, Kay, Noble, Garfield, and Logan Counties, but a few have been found in Tillman and Comanche Counties.

Because the Texas beds have been most thoroughly explored and have yielded the largest number of vertebrate fossils and are most completely exposed by the erosion of the surface, they are here taken as a typical region and will be described with considerable detail; other regions mentioned will be compared with these beds as the standard.

\section{FORMATION NAMES.}

After reviewing the very considerable literature, it seems best to the author to retain the names Wichita, Clear Fork, and Double Mountain, proposed by Cummins. Gordon " retains the name Wichita "for the formation overlying the Cisco," with a revised description, and abandons the name Albany. He describes the upper portion of the beds as "undifferentiated Clear Fork and Double Mountain." To one who, in searching for fossils, confines his attention to limited areas and passes slowly over the beds intent on details, and is frequently occupied in an attempt to follow a single layer, these beds present a hopeless tangle. The author has elsewhere expressed his inability to distinguish a clear dividing-line between the Wichita and the Clear Fork, but now believes that it may be recognized at the first appearance of beds of limestone, although Gordon includes some of these in the Wichita series. To the stratigrapher who passes over the country more rapidly, scanning large areas and correlating, by resemblances based on the average character, a more satisfactory separation may be possible.

Gordon's latest statement concerning the usage of names is as follows: ${ }^{b}$

"Although much has been written concerning the beds between the Cisco formation and the Triassic beds which underlie the 'Staked Plains,' much detailed stratigraphic work remains to be done in this region before authoritative statements can be made about the classification of these beds. On the evidence of fossil remains, found chiefly in the lower beds in Baylor and Archer Counties, these strata are now assigned by most geologists to the Permian. These rocks, as they exist in the Wichita region, were subdivided by Cummins into the Wichita, Clear Fork, and Double Mountain formations. The lowest formation, the Wichita, consisting mainly of red clays and sandstones, is seemingly a near-shore or delta deposit, and in it are found the remains of reptiles and plants of Permian age. Interstratified with the clays and sandstones in the upper part of the formation are beds of limestone containing marine invertebrates, of which a large proportion are Pennsyl-

a Gordon, Jour. Geol., vol. I9, p. 125, I9II.

b Gordon, U. S. Geological Survey, Water Supply and Irrigation Paper No. 317, pp. 21-22, I913. 
vanian types and few, if any, are considered characteristic of the Permian of Europe. South of Baylor County the Clear Fork formation rests conformably upon marine strata, consisting mainly of blue clays and shales, including considerable thicknesses of limestone containing marine invertebrates. Neither reptilian nor plant remains have been reported from these beds. The Pennsylvanian aspect of the fauna led to the assignment of these beds, under the name 'Albany,' to the Pennsylvanian, in the earlier reports, although they were recognized by some as being possibly of Permian age.

"Subsequently Cummins asserted the equivalency of the Wichita and the 'Albany' formations and recommended the abandonment of the name 'Albany.' Adams corroborated Cummins's conclusion as to the equivalency of the beds included in the Wichita and 'Albany' formations, but recommended the abandonment of all the names, Wichita, Clear Fork, and Double Mountain, as 'having no stratigraphic significance.' In a paper by the writer and others, Cummins's conclusion as to the identity of the 'Albany' with the Wichita and likewise the Permian age of the formation is confirmed. It is shown also that the definition of the Wichita as a formation is sufficiently established to warrant the retention of the name, and that usage is followed in this report. It is to be noted, however, that some limestones in Baylor County which Cummins regarded as belonging to the Clear Fork are the equivalents of the upper beds of the 'Albany' and are here included in the Wichita. The upper Permian beds included under the names Clear Fork and Double Mountain in the Texas reports have had very little study, and no attempt has been made to determine a definite line of division between the two formations. In this report these beds are classed as undifferentiated Clear Fork and Double Mountain."

THE WICHITA FORMATION.

Cummins a originally described the Wichita as follows:

"The Wichita Beds are the lowest in the series, and are composed of sandstones, sandy shales, clays, and a peculiar conglomerate. The sandstones and sandy shales are red, gray, and variegated, often containing large oval concretions, ranging in size from one-quarter of an inch to several feet in diameter. The sandstones are often shaly in structure, while in other places they are massive. They are often ripple-marked and at other places have a cross-bedded structure. The concretions are very hard, and retain the peculiar structure of the sandstone in which they occur. The clays are red and bluish. In the red clays are nodular masses of clay, iron, and lime, which often take the form of geodes, filled with tabular lime-spar in the center. The bluish clay is copper-bearing in many places. The conglomerate is composed of rounded pieces of clay or clay ironstone, cemented together by iron. Fossils occur in all these beds, which consist mostly of plants and vertebrates, very few invertebrates being found. The largest number of the vertebrates described by Professor E. D. Cope were taken from the Wichita Beds."

In the Second Annual Report of the Texas Geological Survey, page 400, Cummins gives the following additional description of the Wichita Beds:

"The Wichita Beds, which are the lowest in the series, are easily distinguished from the others by their peculiar characteristics. These beds are composed of sandstones, clay beds, and a peculiar conglomerate. There are no limestones in

a First Annual Report, Geological Survey of Texas, I889, p. I86. Second Annual Report, Geological Survey of Texas, 1890 , p. 400. 
it from top to bottom. The sandstones are of various colors. The clays are red and bluish. In places the clay is copper-bearing, yet this is not entirely peculiar to these beds, as the same thing occurs in the Clear Fork Beds. In the red clays are iron concretions that exist in places in great abundance. The peculiar Permian conglomerate which is found in this connection is composed of clay, or clay ironstone, in a ferruginous matrix."
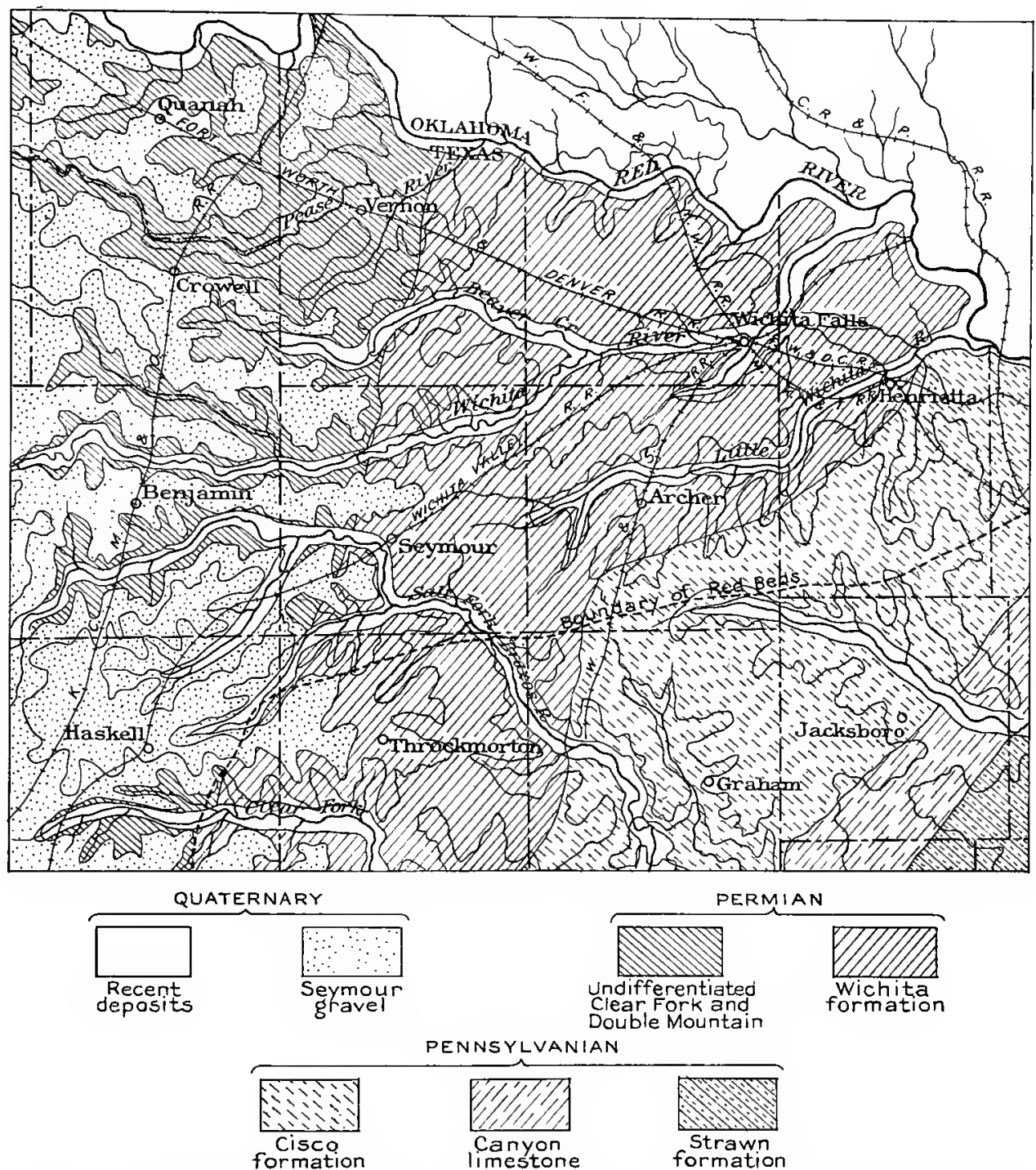

FIG. I.-Map showing Gordon's idea of the distribution of the Wichita, Clear Fork, and Double Mountain formations in Texas. (After Gordon.)

Gordon, ${ }^{2}$ in I9I I, gave an account of the same beds. He regards the Wichita as extending much farther to the west than does Cummins or the author, and includes much that was previously described as Clear Fork. In discussing the Red Beds of Texas east of a line drawn southwest from near the mouth of the Pease River through Seymour to the northeastern 
corner of Haskell County and thence southward, he says that it is the type area of the Wichita formation:

"The western part of this area is characterized by the occurrence of beds of limestone and blue shale interbedded with red clays and sandstones, while the eastern part is notable for the entire absence of limestones and the very limited development of blue shale and clay. If a line be drawn from a point where the Salt Fork of the Brazos crosses the boundary between Throckmorton and Young Counties, a little east of north to the Red River, it will mark approximately the boundary between the areas thus lithologically distinguished. ***" (Page i I2.)

"Rocks of the Wichita Area.-East of Baylor County the rocks consist for the most part of red concretionary clays, red sandstones and sandy shales with occasional beds of blue shales, and bluish to grayish-white sandstones. Limestones are conspicuously absent. Occasional impure nodular layers occur, however, which contain considerable calcareous matter, but these do not constitute strata of limestone. The sandstones are usually soft and distinctly cross-bedded. In some places they are shaly, in others massive. Some layers are streaked and specked with grains of black iron oxide, while others contain nodular masses and concretions of iron ore.

"The clays are mostly deep red or red mottled with bluish-white and drab colors. The red clays contain an abundance of nodular concretions of irregular shape, varying in size from that of a pea to masses 4 or 5 inches in diameter. They consist of clay, iron, and lime, and are at times hollow or with the interior filled with calcareous clay or lime carbonate. In some cases they are flattened and stand in vertical position in the clays, suggesting their origin through the filling of fissures.

"Occasionally a bed is met with consisting of rounded lumps of hardened clay cemented together by ferruginous matter, representing what Cummins called a 'peculiar conglomerate.' This formation is believed to have had its origin in the breaking-up of a bed of clay by running water or wave action.

"In places the bluish clays are copper-bearing. Efforts to mine these deposits have not been profitable. The ore occurs in the form of small nodules in the clays and also as a replacement of wood.

"In the sandstones occasional traces of plants occur, and sometimes remains capable of identification are found. White reports Toniopteris from the sandstones near Fulda. The stratification of the beds is very irregular. The sandstones, shales, and clays grade into each other both vertically and horizontally. Moreover, there is a monotonous similarity in the sandstones and shales respectively throughout the area, which, taken in connection with the absence of any persistent, easily recognizable stratum, renders the stratigraphic correlation of the beds, except within very narrow limits, practically impossible. In eastern Clay and Montague Counties, the beds, considered Cisco, show a greater development of sandstones, some of which are conglomeratic. In the western part of the area, however, no true conglomerates were observed. $* * *$

"In the bluffs of the Wichita River, in the northwestern corner of Wichita County, some beds of limestone, aggregating 4 feet in thickness, appear at the top of the escarpment on the west side of Horseshoe Lake, and outcrops of these appear at intervals along the boundary of Archer and Baylor Counties. The limestone is earthy, very hard, dark blue where fresh, and weathers to dark brown or black. It is underlain by 4 feet of blue clay. The remainder of the section to the foot of the hill, about roo feet, consists of red, concretion-bearing clay, with a limited development of red and white shaly sandstone. From this point west the stratification becomes more regular, consisting of the blue shales alternating with red, 
the red being predominant, with an occasional bed of dark earthy limestone containing usually an abundance of poorly preserved fossils.

"At the Bar-X Ranch on the Wichita River, in the northeast corner of Baylor County, near the Old Military Crossing, several ledges of hard limestone appear in the river bluffs, separated by varying thicknesses of blue shale, alternating with red clay. The beds dip to the westward at inclinations estimated at 20 to 30 feet per mile. Proceeding up the river from this point, limestones appear at intervals in increasing development, the best outcrops occurring about 2 miles east of where the Seymour-Vernon road crosses the river. Here an escarpment 90 feet in height has the lower two-thirds composed of red and blue shales alternating with beds of limestone. The middle of the section consists of red and concretionary clays and sandstones. Some of the ledges of limestone are massive, but others are thin-bedded and shaly, and separated by varying thicknesses of bluish clay. Locally the thin-bedded limestones and their included shale grade horizontally into more massively bedded limestones. Fossils are not plentiful in this locality. The same beds are exposed again northward in the banks of Beaver Creek. At Seymour the limestones are well exposed in the banks of the river, where they are quarried to some extent and furnish a stone that is well adapted to ordinary uses. The beds are here transected by the Salt Fork of the Brazos, which flows in a relatively narrow valley between steep bluffs 200 feet high, made up of interbedded red and blue clays and limestones.

"The limestones of Baylor County area are generally fossiliferous. Owing to the hardness of the rock, however, good specimens are difficult to obtain. Toward the south there is an increase in the development of blue shale and limestone, while the red clays and sands show a corresponding diminution.

"That the limestone series of Baylor County is the equivalent of the 'Albany" formation of the southern area is fully established by both the stratigraphic and the faunal evidence. The beds in the northern area, which include the limestones, shales, and sandstones of Baylor County and the sandstones and shales of Archer and Wichita Counties, constitute the Wichita formation" (p. 122).

In a later paper Gordon " gave the following account of the Wichita:

"The Wichita formation underlies practically the whole of Wichita, Baylor, Throckmorton, and Shackelford Counties, a considerable part of Clay and Archer Counties, and a small part of Young County. In Shackelford County it consists of blue clays and shales with thick beds of limestones which, on account of their greater resistance to erosion, crop out in a series of eastward-facing rock scarps. The limestones, which constitute about a third of the formation, are blue, gray, and yellowish, and for the most part massively bedded. They are generally hard, semicrystalline to compact, but some beds are friable and chalky and others are rough and earthy in texture. Thick beds and thin and shaly beds alternate. The remainder of the formation consists of blue, gray, and black shales. The limestones contain an abundance of marine fossils, but well-preserved specimens are difficult to obtain.

"Farther north there is a marked diminution in the proportion of calcareous sediments, with a corresponding increase in argillaceous and arenaceous materials. Some of the clay beds in Shackelford County are sandy, but toward the north the sandy sediments become more and more prominent, many of the layers taking on a red color. Red, white, and yellowish sandstone beds also make their appear-

"Gordon, U. S. Geological Survey, Water Supply and Irrigation Paper No. 317, 1913, p. 22. 
ance and constitute a marked feature of the formation in Archer and eastern Baylor Counties. The red sediments increase in amount northward until, in northern Throckmorton County and beyond, the red color dominates in the formation.

"Throughout the northern area the clays are red or red mottled with bluishwhite and drab colors. The red clays contain an abundance of nodular concretions of irregular shape, ranging from those the size of a pea to masses 4 or 5 inches in diameter. Many are elongated or subspherical, and some are flattened and stand vertically in the clay, suggesting their origin from the filling of fissures. They consist of clay, iron, and lime, and some of them are either hollow or have their interiors filled with calcareous clay. Here and there is a bed that consists of rounded lumps of hardened clay cemented together by ferruginous matter, which Cummins called a 'peculiar conglomerate.' It is suggested that this deposit may have had its origin in the breaking up of a thin bed of clay soon after deposition, by the action of running water or waves."

It will be noted that both Cummins and Gordon insist on the absence of any limestone in the lower beds, and, though Gordon has shown that the limestone of Baylor County can be traced southward into the upper "Albany," the author is inclined to believe that the limestone appearing in the eastern part of Baylor County, called Beaverburk limestone by Udden, ${ }^{\text {a }}$ marks so definite a change in conditions that it should be considered as the first member of a separate formation, and the author believes that Gordon's map (fig. I, p. 9) places the western edge of the Wichita too far to the west and that the line drawn by Cummins is more nearly accurate.

Transition of Limestones Into Red Beds.

On the east the Wichita beds shade through red shales and red limestones into pure limestones. This fact has been only slowly accepted, but now seems proven beyond doubt. The following pages contain the accounts of this phenomenon collected from the various authors.

Adams $^{\mathrm{b}}$ was the first to call attention to the importance of this change and reported his observations in several papers:

"In tracing the outcrops of the limestone formations of the Carboniferous of Kansas, the writer observed that in going southward there is a gradual transition in the character of the sediments to those which are more arenaceous, and that there is a thickening of the shales and sandstones and a thinning and final disappearance of some of the limestones."

Adams then gives full details of his tracing of the Fort Scott and Elk Falls limestones from Kansas into Oklahoma, where the same series becomes arenaceous and red.

"From what is known of the Permian limestones of Kansas, they will be found, when followed southward, to diminish in thickness, and this change will be accompanied by a transition to more sandy beds. 'The Wellington Shales' are probably represented southwestward by formations which are red. The approximate limit of the red color is a line diagonal to the strike of the formations, and is found to

"Udden, Bull. University of Texas No. 246, I9I 2, p. 3 I.

${ }^{b}$ Adams, Amer. Jour. Sci., vol. XII, 1901, p. 383. 
correspond in a general way with the line drawn by Mr. Cummins as separating the Carboniferous and Permian."

"The distinctions which have been thus far outlined in Kansas do not hold when the rocks are followed southwestward along their strike into the Indian

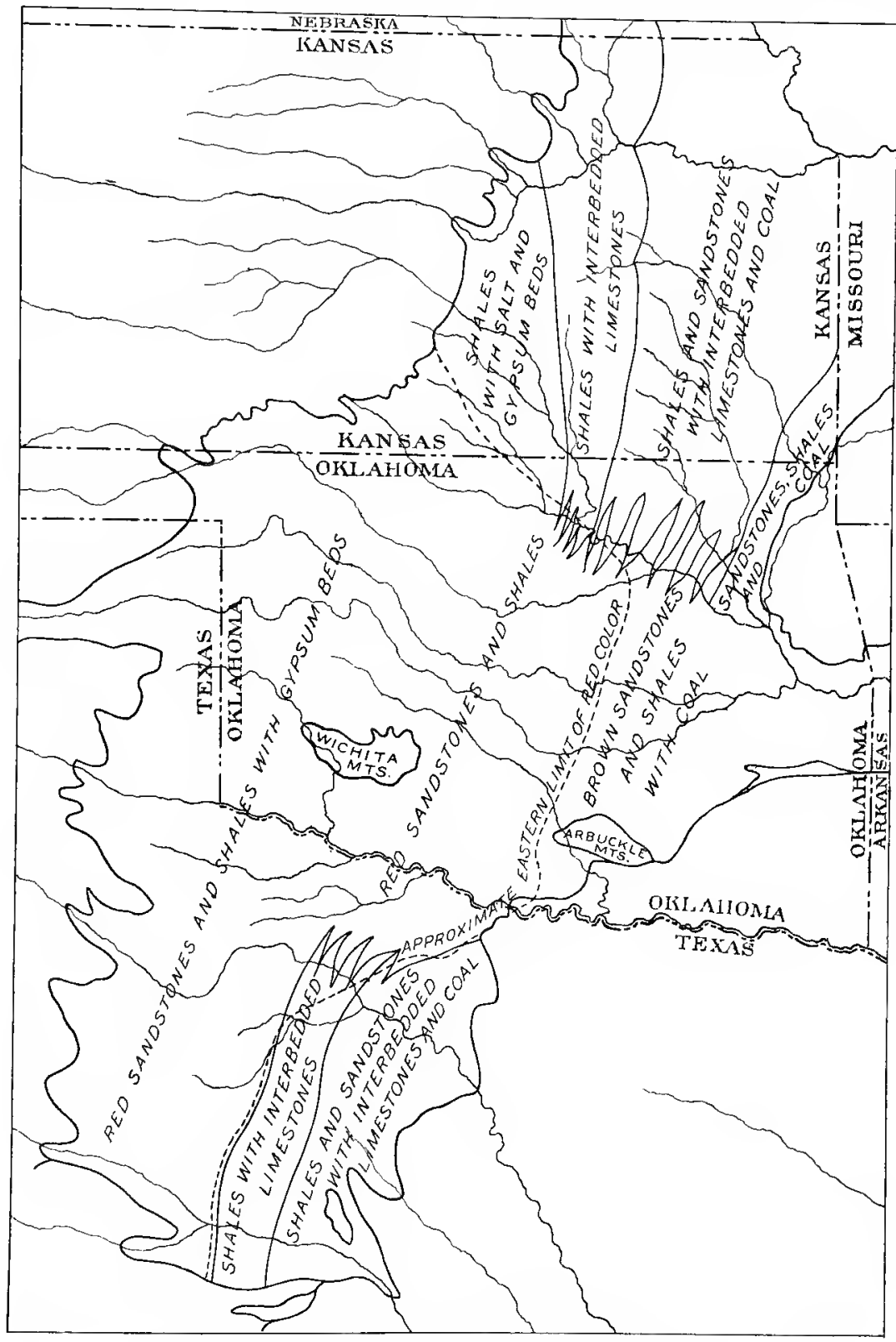

FIG. 2.-Map showing relation of Permo-Carboniferous limestones and Red Beds in Kansas, Oklahoma, and Texas. (From Adams.)

Territory. Approximately along the Arkansas River, or a little south of that stream, the interstratified limestones disappear from that section, and the formations are accordingly shales and sandstones. Moreover, the rocks in the Indian

A Aull description of conditions, with maps, is given by Adams in Bulletin of the Geological Society of America, vol. 4, p. I9I, and U. S. Geological Survey Bull. 21 I, p. 71, I903. 
Territory gradually assume a red color in the higher portions of the section, the line of transition to this color being diagonal to the strike. The Red Beds of Kansas belong to this phase."

"In Indian Territory" and Oklahoma the limestones thin out and disappear from the section approximately along the Arkansas River. The striking feature of the series south of the Arkansas is the transitions from sandstones and calcareous shales with coal-beds, to red sandstones and shales. The line marking approximately the limit of the red color cuts diagonally across the stratification."

In another report, ${ }^{\mathrm{b}}$ giving results of a reconnaisance made for the purpose of reviewing the mapping done by Mr. Cummins of the Texas Survey, Adams says:

"The limestones of the Albany division, although they thin out northward, extend across the line drawn as the contact between the Carboniferous and the Permian, and are represented in the Clear Fork and Wichita divisions."

In 1909 Beede $^{c}$ gave the following account of the transgression of the red color into the limestones:

"In the region south of the western end of the Arbuckles the Red Beds lie unconformably upon the tilted and eroded Pennsylvanian rocks. It appears that the Albany-Wichita sea of northwest Texas transgressed over this region during a time of slight depression, the waters covering the western end of the Arbuckle Mountains, swinging eastward on their northern slope as far as the Seminole country. According to Cummins, there is no unconformity in Texas between the lighter sediments and the Red Beds, the transition between the Albany and the Wichita being a gradual lateral one. The transgression of the Red Beds in the Arbuckle Mountains may, then, be regarded as a northeastern or eastern encroachment of the Wichita sea, or conditions of sedimentation, as all these beds may not be marine. Whether this Arbuckle unconformity extends northeastward to the easternmost limit of the Red Beds has not yet been determined, and indeed may be very difficult to determine, where the unconformity would resolve itself to a mere disconformity of the layers of shales, and perhaps accompanied by a greater or less reworking of the lower deposits. Gould, who has been over this region between the Arbuckles and the Arkansas River many times, states that he knows of no unconformity. If no unconformity exists to the north of the Arbuckle Mountains, it seems probable that the first Permian emergence began here and the deposition of the Red Beds in the Seminole country is the first record of it, the later sediments from the Arbuckles reaching farther north. Regarding the gradation of the upper part of the Kansas section into the Red Beds in northern Oklahoma, there can be no doubt whatever, and the same is probably true of the central part of the State.

"The Arbuckle and Wichita Mountains are probably the source of much of the red sediment, in which they are partially buried, and the former mountains are directly responsible for the eastern extension of these beds into central Oklahoma. The extent to which the lighter-colored sediments of Kansas and Texas are replaced by red sediments in Oklahoma and near it represents in a rough way the limits of the influence of these mountains on the deposits of the time by the spread

a Adams, Lithologic Phases of the Pennsylvanian and Permian of Kansas, Indian Territory, and Oklahoma (Abstract), Science, vol. I5, p. 545, 1902.

b Adams, Abstract of paper read before Geological Society of Washington, Science, vol. I6, p. I029, 1903

'Beede, Jour. Geol., vol. 17, p. 713, I909. 
of their sediments. By the time the deposition of the light-colored sediments had ceased the conditions had become such that nearly all the sediments derived from the land surrounding this basin were red.

"In the Oklahoman region the deposition of red sediments began, perhaps, as low as the Howard or Topeka limestones, and perhaps as high as the Emporia or Americus limestones. The deposits then seem to be uninterrupted until the unconformity below the Dockum beds (Triassic) in the Texas Panhandle is reached. Some of these beds appear to be of subaërial origin, as has been shown by Case, ${ }^{\text {a }}$ while others are certainly marine. Careful petrologic study will probably demonstrate that much of the arenaceous material is wind-blown sediment, more or less reworked by currents or waves as the regions were submerged or flooded. That the sea covered the entire area from Kansas to southern Texas and New Mexico atone time may be questioned. If it did, the sediments contained were of such a nature and abundance, or the waters so concentrated, as to preclude the free migration of a normal marine fauna throughout the basin. That marine conditions prevailed, at least locally, is demonstrated by the Whitehorse and Dozier faunas.

"In Texas normal deposits were laid down in higher horizons than in Oklahoma, and in Kansas there are reasons for believing that the light-colored sediments were laid down at an even later date than in Texas. These conditions are illustrated by the subjoined table [fig. 3], showing a vertical section of the Carboniferous and Permian rocks of the three States."

In I9I2 Beede ${ }^{\mathrm{b}}$ gave a second account of the same phenomenon:

"In tracing the limestones and shales of the basal Permian beds of Kansas southward into Oklahoma, the relationship of the light-colored sediments to the red sandstones, red shales, and red limestones of Oklahoma is clearly revealed. It is shown that some of the heavier ledges of limestones first become sandy along their outcrops in patches a few rods across. Farther south the sandstone areas increase in size until the limestone appears only in local areas in the sandstones, and is finally wanting. Traced farther southward, the sandstones become deep red or brown, with local areas of white. The decimation of the fauna sets in as

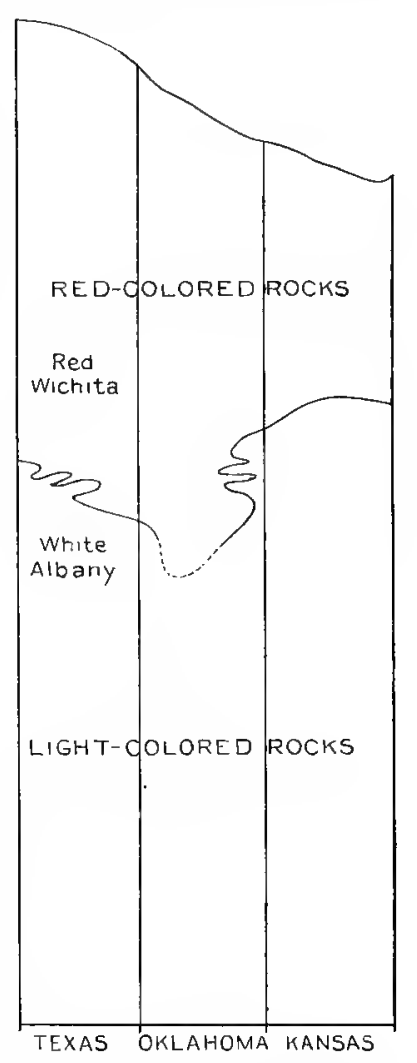

FIG. 3.-Chart showing relation of the Permo-Carboniferous rocks in Oklahoma, Kansas, and Texas. (From
Beede.) the limestones diminish, and the remains of life are not found far beyond the limits of the limestones. The shales become red very much farther north than do the sandstones, and are frequently more deeply colored. Some of the lower limestones become red before they change into sandstones. The sandstone ledges continue for some distance southward as rather even, uniform beds, but farther on they are found to thicken and thin in a somewhat systematic manner.

"Several ledges of sandstone frequently occur in a single section, and, where one of these ledges is found thickened, the others are apt to be thicker than normal. Likewise, they are all found to be thin over certain areas. The regions of thickening

a Case, Bull. Amer. Mus., vol. 23, 1907, p. 659.

b Beede, Science, vol. 35, No. 896, I912, p. 348 . 
and thinning were found to be parallel belts lying north and south at right angles. to the major drainage-lines. Two of these belts, together with an intervening region about 8 miles across, were studied. The sandstones thicken at the expense of the shales, sometimes eliminating them. In one instance a thin limestone was traced southwest into one of these zones. A sandstone 20 feet or more beneath the limestone thickens and rises above the limestone, and practically unites with the sandstone some distance above it. The limestone seems to die out a few feet from the sandstone, but farther west the latter shrinks to its normal thickness, and the limestone is present in its proper position, with its usual characteristics."

As early as $\mathrm{I} 897$, Cummins noted the same thing, but did not grasp its general character."

"By walking along the outcrop every foot of the way we were enabled to note the gradual change in the lithological character of the bed." [Following a prominent bed of the Albany northeastward] "we found the limestone *** gradually changed in composition to a calcareous sandy clay, entirely destitute of fossils. *** North of the Brazos River, in the area heretofore designated as the Wichita division in previous reports, the strata of the escarpment became more and more composed of red clay, and the limestone beds less conspicuous. The limestone gradually loses its limy nature."

Gordon records the same observations: ${ }^{\mathrm{b}}$

"The red sandy shales and red sandstones in the Wichita Valley region were replaced southward in large part by blue shales, light-colored sandstones, and limestones. In some places the transition from a sandstone to a limestone was plainly seen. $* * *$ It is the conclusion of the author that the red beds of this region are the near-shore representatives of the Albany, and the decision as to their age will rest upon that of the latter."

In I9I I, Gordon, ' discussing the relation of the Albany to the Wichita, says:

"When traced northward, the limestones of both the 'Albany' and the Cisco formations diminish in thickness, while there is a corresponding increase in the intervening beds of shale. In the case of the 'Albany,' the limestones show also a change, becoming more earthy and irregular in their texture, and some of the beds passing into gray indurated clays. The few limestones in the upper part of the Cisco formation disappear entirely in the northern part of Young County. Along with this change there is an increasing development of red clay, alternating with blue. $* * *$

"At Fane Mountain, a low elevation in the southeastern corner of Throckmorton County, is an outcropping of limestone characterized by an abundance of Myalina permiana. These beds occur at intervals northward in eastern Throckmorton Cotunty, and at Spring Creek in the northwestern corner of Young County they outcrop in the bank of the river about a mile from the post-office. Here the beds show a local gradation into sandstone, suggesting near-shore conditions of sedimentation. ***

a Cummins, The Texas Permian, Trans. Texas Acad. Sci., vol. II, No. I, p. 95, 1897.

b Gordon, The Red Beds of the Wichita-Brazos Region of North Texas (Abstract), Science, vol. 29, 1909, p. $75^{2}$.

'Gordon, The Wichita Formation of Northern Texas, Jour. Geol., vol. I9, I9II, p. I 8. 
"Nowhere in the southern area, so far as observed, are there any indications of unconformity. Notwithstanding the lithological and faunal characteristics which distinguish the 'Albany,' these beds appear perfectly conformable with the Cisco below and the Clear Fork above, nor is there within the formation any indication of stratigraphic discordance. The change in the lithological character of the beds toward the north is evidently the rest1t of differences in the conditions of sedimentation. The character of this part of the formation suggests very strongly its origin on a coastal plain, or river delta, to the south and west of which lay the sea, in which were deposited the marine 'Albany' sediments. The interrelations of the two kinds of sediments suggest oscillation of the shore-line upon a relatively wide coastal plain. These changes may be explained as the result of oscillations of the land surface, or, possibly better, by the slow, but intermittent, sinking of the coastal plain."

In a later paper Gordon "further discussed this point:

"A feature of importance in the Cisco formation, and one which it shares with the next succeeding formation, is the series of changes observed as the formation is traced northward along the strike. These changes relate both to variation in lithologic character and to thickness of beds. In the Colorado Valley, interstratified with the sandstones, clays, and conglomerates, are six or more beds of limestone, each from 5 to 25 feet thick and all aggregating a thickness of roo to I50 feet. In the southern part of the Brazos Valley the calcareous divisions are only about half as thick as they are farther south, and the clays show a corresponding increase in thickness. In Young County the calcareous material diminishes northward at an increased rate until, at the northern boundary of the county, the limestones have practically disappeared, and beyond that point they are represented apparently by irregular nodular masses of earthy limestone in a matrix of clay. With the thinning out of the limestones the shales and sandstones increase in thickness. In Stephens County and farther south the shales are prevailingly blue and the sandstones gray. Red Beds are dispersed sparingly through the formation. The blues gradually give place to reds until in the vicinity of Red River the red color dominates. In this part of the region the rocks consist, for the most part, of red sandstones, clays, and sandy shales, with a few beds of blue shale and bluish to grayish-white sandstones. Limestones are conspicuously absent. ***

"Beds of red clay make their appearance south of Young County, but they increase notably to the north, especially in the upper part of the formation, along with the diminution of the limestones, and they constitute the dominant feature of the formation in eastern Clay and western Montague Counties."

Gould, in discussing the relation of the limestones of Kansas and eastern Oklahoma, describes the change to the red sandstones and shales in several papers.

"While the flint hills in Kansas consist almost entirely of limestones and shales, still on the southern line of the State sandstones have already begun to appear. To the south, these conditions obtain more and more until the limestone is entirely replaced by sandstone. *** South of the State line, the sandstones from the east and the Red Beds of the west begin to approach each other, while the limestone

a Gordon, U. S. Geological Survey, Water Supply and Irrigation Paper No. 3I7, pp. I8-20, I9I3.

${ }^{b}$ Gould, Notes on the Geology of the Seminole, Creek, Cherokee, and Osage Nations, Amer. Jour. Sci., vol. II, p. I 85 , I90I. 
ledges become thinner and thinner, and the flint less pronounced. In general * * , it may be observed that in going eastward from the Red Beds toward the Carboniferous the sandstones and shales, which have been of a deep, brick-red color, become more and more brownish and grayish, and finally lose entirely their characteristic hue and take on that of the older formations. The lithology changes also. ***"

"The Marion and Wellington formations" narrow rapidly in northern Oklahoma, and their place is taken by the Red Beds. Perhaps it is more correct to state that the color of the shales appears to change to the south, and to become red, while at the same time more of the red sandstone comes in, all tending to change the formation in lithological appearance to that of typical Red Beds.

"A section of the Twin Hills, 7 miles east of Ingalls, eastern Oklahoma, shows three ledges of limestone, the thickest of which is not more than 4 feet, while all the rest of the rocks are either red shales or sandstones. Above these limestones are ledges of grayish or red sandstones, which thicken to the south and west, and, in the region between Stillwater and Orlando, assume the red tint so common in the Red Beds. *** The line of separation between the rocks of these two ages (Carboniferous and Permian) must finally be drawn far out in the Red Beds."

" *** These formations ${ }^{\mathrm{b}}$ [Marion and Wellington] narrow rapidly in northern Oklahoma, and their place is taken by the Red Beds. Perhaps it is more correct to state that the color of the shales changes to the south, becoming red, while at the same time more of the red sandstone comes in, so that finally the formation changes to typical Red Beds. On the State line, the distance from the Winfield formation, the upper conspicuous limestone member, to the eastern outcrop of the Red Beds is perhaps 30 miles; on the southern line of Kay County, Oklahoma, it is not more than 15 miles, while farther south the line of separation can not be determined, for the reason that the limestone disappears, and its place is taken by red shales and sandstones. In southern Kansas there are three distinct kinds of Permian rocks: first, the heavy limestones in eastern Cowley County and along Walnut River; second, the bluish and gray clays and shales of the Marion and Wellington formations from Walnut River to western Sumner County; and, third, the typical Red Beds, consisting of red sandstones and clays extending from this point nearly to the west line of the State. In eastern Oklahoma, on the other hand, only Red Beds appear. Thus it is seen that the Red Beds extend farther east in Oklahoma than in Kansas, and that the eastern limit of the Red Beds does not coincide with the line of separation between the Pennsylvanian and the Permian. In other words, the red color of the rocks, which has been thought characteristic of only the Permian of the region, in fact transgresses far into the region of the Pennsylvanian rocks. This means, of course, that the line of separation between the rocks of these two epochs must finally be drawn far out in the Red Beds, and this the writer has attempted to do."

In I9I4 Beede" gave a detailed account of the lithologic and color changes in Oklahoma largely corroborative and supplementary to his former account.

\footnotetext{
"Gould, General Gcology of Oklahoma, Second Biannual Report Oklahoma Geological and Natural History Survey, p. 27, 1902.

b Gould, Geology and Watcr Resources of Oklahoma, U. S. Geological Survey, Water Supply and Irrigation Paper No. 148, p. 35, 1905.

- Beede, Oklahoma Geological Survey, Bulletin 21, 1914, p. 25.
} 
Udden, ${ }^{a}$ in 1912, presented a very full account of the rocks and other deposits of Archer and Wichita Counties, most of which would be included in the Wichita formation as it is conceived by the author:

"It is believed that these sections (see p. 34) represent different parts of a general section some 300 feet thick. They are known to include successive strata measuring about 225 feet, and constituting the uppermost beds exposed in the field examined. We shall regard these sections first as a group representative of a single formation. They all occur within the areal limits of what has come to be known as the Wichita formation." $b$

"The thickest section measures only I30 feet in all, and most of them fall short of 50 feet. The total number of feet of rock described is only a few feet more than $\mathrm{r}, 000$. Some items are known to be repeated descriptions of the same strata, in places where the sections are not very far apart, and many more of them must include beds that are synchronous and were made at the same time.

"From these sections we may obtain a fairly close estimate of the gross nature of the formation. As seen in the exposures, it consists of shales, sandstones, conglomerates and limestones, named in order of their rank as to bulk. Seventy-nine per cent of the total thickness described in the section consists of shale, 20 per cent of sandstone, and less than I per cent each of conglomerate and limestone. There are also gradations between all of these groups. It is believed that the percentage of sandstones determined in this manner is higher than the actual percentage of sandstone in the formation, as this rock stands weathering better than the shales, and is hence more frequently preserved in the outcrops. But the difference between the actual and apparent ratios of sandstone and shale can not be very great. In section 25 [section 34 of this paper] above, where there is a total of I 24 feet of shale and sand, the percentage of shale is 83 , and that of sandstone 17 . The relative quantities of different rocks are shown in the following table, in which the several rocks described and measured in the sections are classified, summed up, and reduced to percentages:

\footnotetext{
"Table showing lolal thicknesses in feet and percentages of different kinds of rocks described in sections seen in Wichila and Clay Counties.
}

\begin{tabular}{|c|c|c|}
\hline & Total feet. & $\begin{array}{l}\text { Per cent of } \\
\text { total feet. }\end{array}$ \\
\hline 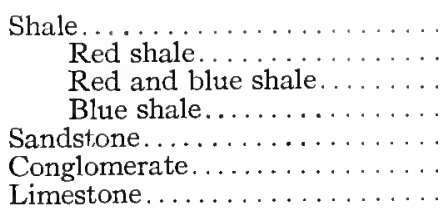 & $\begin{array}{c}789 \\
(580) \\
(\mathrm{rr} 3) \\
(96) \\
201 \\
8 \\
6 \\
\end{array}$ & $\begin{array}{l}79 \\
(58) \\
(\mathrm{I} I) \\
(10) \\
20 \\
.5 \\
.5 \\
\end{array}$ \\
\hline Total. & I,004 & roo \\
\hline
\end{tabular}

AVERAGE THICKNESS OF DIFFERENT BEDS.

"The beds described vary in thickness from less than I foot to 60 feet. Not one of the conglomerates or limestones is more than 3 feet thick, and only I I instances were noted of sandstones exceeding 5 feet. Of these only 3 were more than

a Udden, Bull. University of Texas No. 246, 1912.

b W. F. Cummins, First Annual Report Geological Survey Texas, r889, p. I86; C. H. Gordon, George H. Girty, and David White, Jour. Geol., vol. r9, I9I I, pp. rro-r34, and others. 
ro feet, while none exceeded I $_{5}$ feet. The shales are more heavily bedded. In 43 instances these measure more than 5 feet thick, while there were only 23 beds of shale measuring less, than 5 feet. These relations are more fully presented in the following table:

"Table showing frequency of different thicknesses of strata as described in the sections noted in Clay and Wichila Counties.

\begin{tabular}{|c|c|c|c|c|c|c|c|c|}
\hline Measured thickness in feet. & $x-5$ & $6-10$ & $1 \mathrm{I}-\mathrm{I} 5$ & $16-20$ & $2 I-25$ & $26-30$ & $4^{1-45}$ & $6 r-65$ \\
\hline $\begin{array}{l}\text { Number of shale beds.......... } \\
\text { Number of sandstones....... } \\
\text { Number of conglomerates.... } \\
\text { Number of limestones... . . . . }\end{array}$ & $\begin{array}{r}23 \\
32 \\
10 \\
8\end{array}$ & $\begin{array}{r}17 \\
8 \\
\cdots \\
\cdots\end{array}$ & $\begin{array}{r}\mathbf{1} \mathbf{I} \\
3 \\
\cdots \\
\cdots\end{array}$ & $\begin{array}{l}9 \\
\cdots \\
\cdots \\
\cdots\end{array}$ & $\begin{array}{l}3 \\
\cdots \\
\cdots \\
\cdots\end{array}$ & $\begin{array}{l}3 \\
\cdots \\
\cdots \\
\cdots\end{array}$ & $\begin{array}{l}\mathrm{x} \\
\cdots \\
\cdots\end{array}$ & $\begin{array}{l}\boldsymbol{I} \\
\cdots \\
\cdots \\
\cdots\end{array}$ \\
\hline Number of all kinds of rocks. & 73 & 25 & 14 & 9 & 3 & 3 & $\mathbf{I}$ & $\mathbf{I}$ \\
\hline
\end{tabular}

THE WICHITA SHALES.

"From the observations made in the field it appears that about 73 per cent of the bulk of the shales of the exposed Wichita formation consists of greenish, bluish, or light gray shale, and about ${ }_{3} 3$ per cent consists of alternating layers of red and gray shale, or blotched red and gray shale. ${ }^{2}$ The greater part of this shale is fine in texture, containing very few quartz grains which measure more than one-sixteenth of a millimeter in diameter.

The Gray and Blue Shale.

"The bluish-gray or greenish-gray shales are usually found under the sandstones and limestones. We also find, in similar situations, streaky or blotched mixtures of gray and red shale.

"The gray or bluish-gray shale frequently contains minute fragments of chitinous, brown, translucent fragments of scales of fishes, which sometimes also are found entire. In some of the blue shales, these fragments are found in large numbers. $* * * *$

"Where the gray shales are dark they frequently contain minute imbedded shreds of vegetation, and even entire leaves. Bituminous matter is also frequently present in quantity sufficient to produce a bituminous odor when a fragment of the shale is heated in a closed tube. When large concretions occur in this shale, they are usually flat and consist of lime or of carbonate of iron. Small crystals of marcasite also occur. These, as well as the concretions, have often been oxidized, the concretions being more or less completely changed to limonite, and the marcasite appearing as rusty specks in the shale.

The Red Shale.

"The red shale constitutes the greater part of the exposed Wichita formation. The red color is due to the presence of hematitic material. The red tints vary from yellow to light red, dark red, purple, brown, and dark brown. Some of the red shales are highly ferruginous, containing no less than to per cent of oxide of iron. These are generally very fine in texture. The usual percentage of ferruginous material is very much less, probably less than 5 per cent.

"In its texture the red shale is very much like the blue shale, and varies from very fine material to sandy shale. A small part of the shale consists of quartz grains measuring more than one-sixteenth of a millimeter in diameter. With this ingredient there are usually some scales of mica. The hematitic material is present in a state of extremely fine subdivision.

"The excess of green and blue shale noted by Udden over that reported by other authors is in part due to the fact that he includes some of the Clear Fork in his Wichita and in part due to the local character of the beds in the area in which he worked. Compare his statement under "Red Shale."-E. C. CAse. 
"The red shale is in many cases somewhat obscurely stratified, showing hardly any lamination or other perceptible structure in beds several feet thick. In places where it is mingled with gray or white layers, the stratification is very trenchantly shown. In some such exposures contemporaneous unconformities are to be seen, where a series of overlying laminated shales bend in conformity to the surface of a local excavation in an underlying horizontally stratified clay or shale.

Concretions in the Shale.

"The red shale usually contains numerous concretions of material which once no doubt was disseminated generally through the body of the shale. Eroded slopes of this shale are frequently closely strewn with these concretions, which remain intact on the surface after the rains have washed away the readily disintegrated matrix in which the concretions were originally formed and imbedded. The common form of the concretions is an irregular spheroid, and the usual sizes are from half an inch to 4 or 5 inches in diameter. They usually have a very irregular exterior surface, which in some may be described as irregularly botryoidal, as mammillated, pitted, furrowed, ridged, or which may be so entirely irregular as to defy any general description. Such are the greater number. Only in rare cases are some found with a smooth outer surface. In some cases they approach a cylindric form, and it appears that such concretions have started to form either in some tubular cavities in the shale, or around some narrow cylindrical bodies buried in the shale, for some such concretions still show traces of a centrally located tubular cavity. Some concretions of this form were noted at a horizon in a red shale, which at another place, a mile distant, contains sandy layers with fossil leaves, and the suggestion prompts itself that these concretions have grown around roots or small branches of plants originally imbedded in the shale. Some of these concretions were seen to have had an inclined position in the strata. Another instance of cylindric forms was noted in some sandy shale. In this case concretionary lime had cemented the fine sand along a line vertical or slightly inclined to the stratification planes, causing a cylindric or rather cone-shaped form to weather out from the shale.

"In some places the concretionary material has been deposited along certain structures in the shale, as along sandy layers, or in joints which have developed in the clay. When these joints have opened up in the process the concretionary material takes the form of irregular fissure veins. Some calcareous veins of this kind were noted in a shale bank a short distance northeast of Electra. A system of intersecting joints, closely set, seem to have been developed in the clayey matrix next to some of the large concretions, with the result that the calcareous filling in these fissures extends out and away from the concretions, and forms an irregular network of ridges on their surfaces. The mammillated and irregularly botryoidal surface on some concretions is clearly the result of an interruption of the concretionary growth, and of a later resumption of the same, which has been more localized.

"Internally the concretions in some cases show an irregular concentric structure, and in one locality this was seen to consist of numerous smooth and even concentric layers. More frequently they have radiating internal fissures which are filled by somewhat pure carbonate of lime, either in the form of crystalline calcite, of amorphous calcite, or of a white powder of the same mineral. In other instances the internal structure shows that some concretions are aggregations of many concretions of the smaller and greatly variable sizes."

SANDSTONES.

"The sandstones of the Wichita formation constitute something less than 20 per cent of the whole in the exposures. They are mostly light gray in color, though some are red, dark gray, or mottled. 
"The development of the sandstones is irregular. They frequently change in thickness, and may run out in a few hundred feet. They can seldom be traced in continuous outcrop for more than a mile or two."

Texture.

"The sandstones are fine in texture, about 85 per cent of the weight of the sand consisting of grains measuring from one-fourth to one-sixteenth of a millimeter in diameter. Grains measuring more than one-fourth of a millimeter are scarce, constituting only a small fraction of I per cent, in case any such grains are present at all. Compared with other sands the Wichita sands are well sorted. They contain very little material in which the grains measure less than one-sixteenth millimeter in diameter. In this respect the Wichita sand is a true beach sand. To plainly present these characteristics, a few mechanical analyses have been made, as shown [below]. Analyses of the three Cisco sands are also introduced for comparison.

"Table showing the mechanical composition of sandstones in the Wichita and the Cisco formations, in percentages of weights of different grades of coarseness.

\begin{tabular}{|c|c|c|c|c|c|c|c|c|c|c|c|}
\hline \multirow{2}{*}{$\begin{array}{l}\text { Diameter } \\
\text { of sand grains. }\end{array}$} & \multicolumn{4}{|c|}{ Cisco sands. } & \multicolumn{7}{|c|}{ Wichita sands. } \\
\hline & A & B & $\mathrm{C}$ & $\mathrm{D}$ & $\mathrm{E}$ & $\mathrm{F}$ & $\mathrm{G}$ & $\mathrm{H}$ & I & $\mathrm{J}$ & $\mathrm{K}$ \\
\hline I to $1 / 6 \mathrm{~mm}$. & I & tr. & tr. & tr. & . & . & & & . & & \\
\hline $1 / 3$ to $1 / 4 \mathrm{~mm}$. & 20 & 8 & tr. & 9 & . & . & $\therefore$ & tr. & - & . & tr. \\
\hline $1 / 4$ to $1 / 8 \mathrm{~mm}$. & 43 & 69 & 84 & 67 & $8 I$ & 79 & 62 & 57 & 43 & 28 & 57 \\
\hline $1 / 16 \mathrm{~mm} . .$. & 26 & 9 & IO & 15 & I I & I3 & 27 & 29 & 38 & 48 & 28 \\
\hline $1 / 16$ to $1 / 32 \mathrm{~mm} \ldots$ & 10 & 4 & 6 & 7 & 8 & 8 & I I & I 4 & I9 & 24 & 14 \\
\hline $1 / 1 / 2$ to $1 / 64 \mathrm{~mm}$. & . & . & . & & . & & & & tr. & tr. & tr. \\
\hline
\end{tabular}

A, South of Bellevue, Clay County.

B, 5 miles east of Henrietta, Clay County.

C, Near Bellevue, Clay County.

$\mathrm{D}$, Averages for Clay County.

E, Finder's Butte, 3 miles WNW. of Holliday, Wichita County.
F, 3 miles west of Burkburnett, Wichita County. G, Wichita Falls, Wichita County. $\mathrm{H}$, Butte on Palo Pinto School lands, Wichita County. I, Tenth Cavalry Creek, Wichita County.

J, Electra red sand, Wichita County.

$\bar{K}$, Average for Wichita County.

"The Wichita sands do not appear to be greatly worn, for even the coarser grains are not well rounded. The surface of the sand grains very generally shows the effect of etching, being roughened or very irregularly pitted. This etching has no doubt been effected by the solvent action of percolating ground water, which at times probably has contained a comparatively large amount of alkalies in solution. Characteristic Bedding in Sandstones.

"We have already noted that in their mechanical composition the Wichita sandstones resemble beach sands, or near-shore sands, being well sorted. Physical conditions of this kind are also indicated by other features of sedimentation. In a few places the sandstone is a freestone, showing no preferential planes of cleavage in any direction, and no bedding planes of any kind. But no strata of this kind were noted exceeding 4 or 5 feet, nor did these appear to run far horizontally. It suggests itself that such beds may once have been small wind drifts on the sandy beaches, which happened to remain undestroyed, and to be buried under other sands later brought by the coastal currents of the sea. Usually these sandstones are distinctly stratified and are built in layers from a few inches to a foot or two thick. Sometimes these layers show a fine horizontal lamination. There extend smooth and straight division planes horizontally in the stone for many yards in both dimensions of a horizontal plane. These divide the layers into thin laminæ from a sixteenth to a fourth of an inch thick. Even the thinnest of these laminæ seem to be traceable for many feet, and with favorable weathering slabs of such rock may be split into plates not much thicker than a card-board, and as large as 
a man's hand. In places these thin layers are marked by parallel varicose lines, which seem to be wave-marks. In other places the division planes are themselves thrown into very shallow, hardly perceptible folds, a few inches wide. These are evidently incipient ripple-marks, for in some places they are found in association with well-developed ripples. Ripple-marks are not very common features in the bedding of these sands, and were noted at only a few places in this field. Cross-bedding.

"The most frequent and conspicuous bedding characteristic of the Wichita sandstones is cross-bedding or so-called false bedding. There are few outcrops of sandstone where this form of stratification may not be found. The thinness of the beds in this field prevents it from being developed on a grand scale. The thickest single cross-bedded strata noted here are not more than 3 feet in thickness, and the common thickness of single layers of this kind is less than a foot. On the other hand, the development of small, fine work in cross-bedding seems to have reached a culmination in these sands. Layers no more than a half-inch thick are often seen to be quite regularly cross-bedded. It is evident that this cross-bedding is the result of currents in the direction of the slant of the false bedding. These slants are, in each case, the indices of local currents which produce them. In each outcrop there may often be found several directions of these slants, but usually one or two directions prevail. For the purpose of securing some information on the general direction of the transporting currents which brought this sand, some observations were made on the direction of the slants in the false bedding of the thickest strata. Each slant noted was referred to one of eight directions of the compass, the four cardinal points and the four intermediate points. In all, i 25 observations were taken, 30 in Clay County and 95 in Wichita County. ${ }^{a}$

Significance of Cross-bedding.

"The greater frequency of the westwardly directed depositing currents is clearly shown by these observations. It would, nevertheless, be hasty to conclude that the resultant direction is a true index of the direction from the land to the sea at the time of the making of those beds. The general direction of transportation in sand bars and sand beaches is not always from the land seaward. It may as well be parallel with the coast-line. But it can not be largely from the sea landward. All that we may safely infer from these observations is that the land at that time was not to the west with the sea to the east. If the ancient shore-line extended in a north and south direction, there must have been an open sea to the west. But if the course of the shore-line was from the east to the west, the land may, so far as these observations are concerned, have been somewhere in a northeast or an east direction. The northward trend of the resultants renders it unlikely that the shore-line extended in an east-west course, as this would require a landward transportation of the sand. The land, hence, probably lay to the east, southeast, or northeast, all evidence considered, with an open sea to the west, northwest, or to the southwest. ${ }^{\mathrm{b}}$

Small Contemporaneous Faulting.

"Some thin and fine-grained layers of sandstone which are interbedded in the red shales in the breaks of Bluff Creek, southwest of Electra, exhibit a peculiar

a The average direction of the inclination was $2^{\circ}$ north of west.-E. C. C.

b Udden's conclusions do not necessarily follow from his observations. It is very probable that the sandstones with their observed dips were deposited in pools on the surface of the subaerial portion of the delta plain and not upon a sea-shore. Other evidence clearly shows that there was a sea to the east and land to the west and north.-E. C. C. 
small faulting, which is believed to have taken place almost immediately after the sand was laid down, and before it had been consolidated to any degree. Layers of sandstone $\mathrm{r}$ to 4 inches thick are faulted along gently but somewhat irregularly curving lines, which run roughly parallel from a half-inch to several inches apart. The displacement at each little fault is from zero to a half-inch. We have seen such faulting in rapidly accumulated soft mud settling on sloping banks under its own weight, and we have no doubt but that these structures have a similar origin. Their presence in these beds indicates that sedimentation was rapid. In some sands belonging in about the same horizon, and in the same part of the field, were also to be seen some vertical or slightly oblique perforations more or less perfect, seldom more than an eighth of an inch in diameter. These are probably either worm borings of some kind or cavities left by imbedded plant structures.

Some Larger Bedding Structures.

"The fact has been mentioned that the sandstone beds can not with certainty be traced for any considerable distance. They disappear, frequently, in less than a mile. Instances of this kind have been referred to in some of the described sections, as in sections 27,29,31,32, 33 [of this paper]. Another case of this kind was noted at a point about 3 miles east of Wichita Falls, where the main wagon road turns up in the low bluff. A silty sand, with a dip that is evidently incidental to the bedding, terminates against a sloping clay surface. The outcrop is somewhat obscure. Other cases of dipping sandstones, where the dip is evidently original in the bedding, were noted in survey $27, \mathrm{H}$. \& T. C. R. R. Co., about 6 miles south and 2 miles west of Electra. At this point a sandstone runs some ${ }_{50}$ yards with a dip of several degrees to the east, but on all sides of this place the formation lies horizontal. Another dip of this kind was noted in the ravines about 2 miles south and $\mathrm{r}$ mile west of Electra. In a hill facing northeast near the east line of the W. W. Carroll survey, some 5.5 miles north and 4 miles east of Iowa Park, some layers of sandstone, interbedded with red shale, dip some ro to 5 degrees to south and disappear from the outcrop. Close to the south the overlying red shale is capped by some thin, gnarly, black limestone, and this lies horizontal. In all of these cases we believe that the dip is original in the bedding, and in several cases the evidence is clear that an excavation has been made in the accumulating clay and sands, and the dipping beds have been laid down on the sloping sides of the excavation. We believe that these excavations may very well have been made by bottom currents in littoral waters, for there are no evidences of weathering or decay along the contacts on the beveled layers. It is well known that sand banks on the gulf coast are continually undergoing changes, and excavations of several feet may be made more or less extensive in the course of a year. Tidal currents are especially effective in such work. The universal occurrence of cross-bedding in these sandstones, and perhaps also the frequent presence of extensive flat and thin lamination which we have described, may perhaps be regarded as additional evidence of tidal action. We believe that these sandstones were originally mostly submerged sand-bars, and in some cases sandy beaches. Wave-marks, marks of rain drops, and rill-marks are not often to be seen. It appears to us that these should be more frequent if the greater part of these sands were emerged beach sands.

CONGLOMERATES.

"In all the sandstones examined in Wichita County and in the northwest quadrant of Clay County, no quartz grain or pebble was noted which was more than a millimeter in diameter. Coarse ingredients from the same source as the 
bulk of the sand have been effectively left behind by the currents transporting the sand. Nevertheless, some coarse sediments were found together with the sands and the shale, but these are, as we might say, of indigenous origin, and have not been transported from the same places as the rest of the material in the sands and the shales. These indigenous coarse sediments may be designated as bone breccias and mud-lump conglomerates. We shall describe the bone breccias in connection with the limestones, of which they make a somewhat rare feature. The conglomerate has been noted by all earlier observers in this field. Mr. W. F. Cummins very aptly referred to it as a 'peculiar conglomerate.' It occurs in most frequent association with sand, quite often appearing as a basal layer under sandstone. Quite frequently it forms separate layers interbedded in sandstone. In the described sections it occurs interbedded in sand in 8 cases, and underlies sandstone and overlies shale in 3 instances. In 4 instances it was found interbedded in shale, which at least in I case was slightly sandy and stratified. The assertion appears to be warranted that the associations of this conglomerate indicate its formation in situations where currents in the depositing waters were active. The conglomerate consists of more or less rounded bodies of indurated and compact calcareous and argillaceous material. Some of these are calcareous, others argillaceous or ochreous. They measure from the size of sand grains to an inch and a half in diameter. Many exhibit an obscure concentric structure, which is most apparent near the periphery. Many have internal fissures, such as characterize clay ironstone concretions, and calcareous concretions in clay beds. These balls, as we may call them, are more or less uniform in size for different beds, having evidently been sorted by the transporting currents. In the coarsest conglomerates noted they perhaps average half an inch in diameter, and in the conglomerate of finest texture the individual pebbles averaged less than one-tenth of an inch in diameter. Balls of the size of a pea are common in samples where the sorting has been the most perfect. These balls or pebbles are embedded in a matrix of clay or of sand, or of a mixture of these. The matrix may be only a filling in the interstitial spaces in the conglomerate, but it constitutes more than one-half of the rock. In some localities the conglomerate has evidently suffered alteration from mineralized ground water, in places substituting copper carbonate, ochre, or wad for the calcareous ingredients in the rock, and in places merely precipitating these minerals in the original matrix.

"Conglomerates like this are indeed not unknown in other formations consisting largely of clay and shale. They have been noted by one of the present authors in the late Cretaceous clays in Brewster County in Texas, and in the Pennsylvanian in Illinois and Iowa. In Ohio a somewhat similar rock has been noted and described "as a "desiccation conglomerate." "

"In his paper on the 'Physical Origin of Certain Conglomerates,' J. H. Gardner ${ }^{\text {b }}$ shows how water-currents which are overloaded with fine mud will form balls which resemble concretions, and William B. Phillips ${ }^{c}$ has described how balls of fine clay are formed in the troughs of the log washers in the treatment of brown ores in Alabama. That most of the balls which make up these conglomerates have been formed by a process of rolling appears likely from the concentric structure which many of them have. But some of the pebbles have evidently withstood more wear than mere mud balls can do. These must have been considerably indurated originally, and they have the appearance of being true calcareous concretions. It is believed that such pebbles in the conglomerates may have been washed out

'J. E. Hyde, Amer. Jour. Sci., vol. xxv, Igo8, p. 400 .

b Gardner, Jour. Geol., vol. xvL, p. $45^{2}$.

- Phillips, Iron Making in Alabama, Alabama Geological Survey, zd ed., p. 55 . 
from clays in which they first were formed by true concretionary growth. The frequent association of sandstone and of these conglomerates with contemporaeous unconformities or local excavations in the clays is significant in this connection. It is known that concretionary growths may form quite rapidly, and on the Gulf coast places may now be found where the waves are beating down banks of recently formed clay, leaving thin layers of calcareous concretions mingled with sand on the beach at the foot of the clay cliff. A sandy conglomeration of such concretions, that perhaps was laid down on a beach in this manner, was noted in the breaks about 4 miles south of Electra. The concretions have evidently been embedded in the upper surface of a stratum of sand, to which they adhere in the exposure. The absence of everything but indigenous material in conglomerates which clearly have been produced by currents of considerable strength suggests isolation of the coasts from mountain lands while the Wichita beds of this region were deposited. The underlying beds of the Cisco formation contain pebbles of chert and of granite, which are derived from the Wichita Mountain uplift. Evidently the geographic ${ }^{2}$ conditions prevailing during the deposition of the Wichita beds were different from those existing during the making of the Cisco beds."

THE BEAVERBURK LIMESTONE.

"While the clays and the sandstones of the Wichita formation are too irregular in their development to be individually correlated, at least one limestone was found which it was possible to follow for a dozen miles or more, even though it may not be quite continuous for this distance. We have called this the Beaverburk limestone, for the reason that it is well developed in the basin of Beaver Creek, and has been traced northeast as far as to Burk Station on the Fort Worth and Denver Railroad.

"This limestone caps the upland bluffs on the north side of the Wichita River in the southwest corner of Wichita County, where it has its greatest thickness and measures about 3 feet. Its outcrops have been traced from this point northeastward across the basin of Beaver Creek, and from there northward and eastward to Burk Station, ***. (See fig. 4, p. 33.) In the Beaver Creek Basin the rock is less than 2 feet thick, and in some places less than a foot. Northeast from the Beaver Creek basin, and in the vicinity of Burk, it is less than 6 inches thick, and is evidently not always present in the section. The horizon where it belongs is, however, marked by a continuation of the dark or greenish-gray shale which underlies. This shale is traceable eastward as far as to the hills 2 miles northwest of Iowa Park. A thin shell of limestone, which may be a continuation of this limestone, was noted at a point on a hillside 3 miles north and I.5 miles east of Iowa Park.

"This limestone is mostly a tough, dark gray rock, that effectively withstands weathering. It has been used very generally for building stone and in foundations at the neighboring ranches. It breaks along two main systems of joints into rectangular and sometimes diamond-shaped blocks, often in sizes small enough to be handled and hauled away. Where the limestone caps a small slope these blocks creep down on its surface, forming a pavement in which the blocks maintain their arrangement in rows for some distance down the slope. (See figs. I and 2, plate 10.) This is frequently seen in the breaks on the Houston and Texas Central Railroad Company survey 33 .

"In its original form the rock is almost compact and structureless, save for the presence of more or less obscure lamination. Under the microscope the sample *** exhibited an exceedingly fine and homogeneous granular texture, the granules 
being somewhere near one-thousandth of a millimeter in diameter, and appearing like the crystals in a fine-textured dolomite. In the granular matrix various curving lines were noted, some of which were very thin embedded small bivalve shells. Several thin sections, cut in three dimensions vertical to each other, of the rock near Burk, consist largely of a tangle of irregularly bending and branching laminate structures, about one-twentieth of a millimeter thick. These lie mostly flat with the bedding planes and enmesh a varying copious matrix, consisting in part of structureless material, and in part of small lump-shaped bodies of lime. There are also various shell fragments, and irregularly shaped impregnations of black bituminous material, scattered through the mass. The structure of the rock suggests that it has been formed, at this point, to some extent from a multitude of thin shells incrusted with lime, which became embedded in a calcareous precipitate mixed with some fine clay. In the Beaver Creek basin and along Wichita River the rock is in many places somewhat porous, and has a dark brown rusty color. These are evidently secondary characteristics, due to solution and infiltration by the ground water. Irregular pockets filled with crystalline calcite must be ascribed to the same cause.

GENERAL SECTION OF THE OUTCROPPING ROCKS.

"Reviewing all the observations made on the outcropping rocks, it is to be noted that less than one-half of all the localities described can with certainty be referred to their proper position in a general section. The Beaverburk limestone and the Bluff bone-bed are the only identifiable units in the field. Of these, the Beaverburk limestone does not extend eastward beyond Iowa Park, and the Bluff bone-bed is not known to extend farther than 4 miles east of Electra. Only in one place were the field conditions such that a measurement could be made of the vertical distance between these two key-rocks. This is near the Webb well, just west of the west boundary of Wichita County, 4.5 miles south of Electra. At this place a shallow well has recently been made, and a thin limestone, readily identified from fragments as the Beaverburk limestone, has been penetrated at the depth of about 45 feet. In the low upland near this well, the Bluff bone-bed lies 20 feet above the curb of the well, so that the distance between these two members in our section is 65 feet at this place, as shown in section 30 [ 35 of this paper].

"The beds above the Bluff bone-bed $* * *$ consist of 30 feet of red clay overlain by some few feet of sandstone. This clay is also exposed north of the railroad a half-mile east of Electra, and in the low bluffs around the artificial lake a mile west of Electra, as well as in the breaks on the east side of Bluff Creek.

"About midway between the two key-rocks there is at one place on Bluff Creek a dark bluish-gray, or almost black, shale, only 2 feet thick, in which occur some flat clay-iron concretions as large as a hand. These, as well as the shale itself, contain fragments of leaves in which the vegetable structure is unusually well preserved.

"The sediments below the Beaverburk limestone are seen in several places in a belt about 5 miles wide, following the north side of the Wichita, from Burk Station southwestward. Such are the strata designated and described as $I, 2,3$ in section $21 ; 1,2,3$ in section $26 ; x$ in section 27 ; and 1,2 , in section 28 . But in none of these places are there more than 30 feet exposed of the beds below the limestones. Section 25 [34 of this paper], which is in the north bluff of the Wichita River, shows the thickest single exposure in the region, and exhibits 125 feet of the sediments underlying the Beaverburk limestone. In all of these localities there are a few feet of sandstone at from 25 to 30 feet below the limestone, and in the deep section on the Wichita River just mentioned there are four such beds of 
sandstone, approximately equal distances apart in the lower i 25 feet seen. The whole succession of beds which it has so far been possible to construct from exposures is, therefore, as below:

Section of the Wichita beds known from exposures.

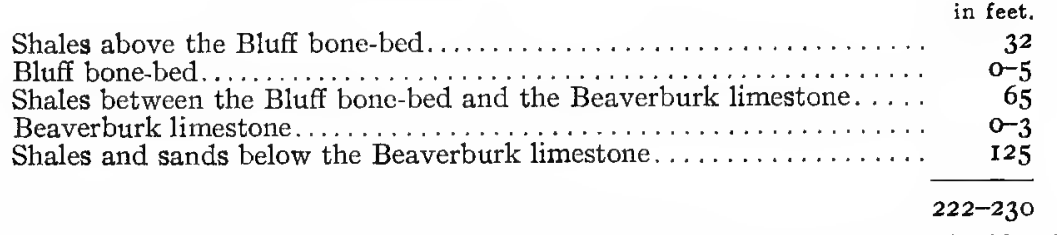

"It is possible that some of the beds described in the east half of Wichita County, and in the northwest part of Clay County, are to be correlated with some part of the above general section, but it does not seem that such correlation can be made in the usual way. There seem to be no identifiable horizons in this part of the field, so far as yet determined."

It is evident from the above description, quoted from Udden, that he believes that a good portion of the Texas Permo-Carboniferous beds were deposited upon or near a sea-shore affected by variable and local currents. Also that he believes that the sea was located to the west, or over the beds discussed, with a land to the east. These ideas are almost diametrically opposed to those held by the author and to those of most, if not all, of the men who have written upon the region. Whichever idea may prevail in the end, it can not detract from the value of the observations made by Udden.

THE CLEAR FORK FORMATION.

The limestones which were considered by Cummins as most nearly marking the base of the Clear Fork appear for the first time a little east of the line which separates Baylor and Archer Counties, and extend to beyond the Big Wichita River, in a nearly north-and-south line. On the north they disappear beneath the surface deposits beyond Burk Station, and on the south they may be traced to a contact with the Cisco, near the northwestern corner of Young County. As stated above, Gordon found it impossible to distinguish between the Clear Fork and the Double Mountain beds and includes a large part of what Cummins regarded as Clear Fork in the Wichita. However this may be finally settled, the fact remains that there is a decided difference between the faunæ of the beds above and below the limestones (see list, p. 96), and the author of this paper is inclined to use the term "Clear Fork" to indicate the series of beds beginning with the limestones and carrying the upper fauna. Cummins has drawn an approximate line between the Clear Fork and the Double Mountain, which passes south near the line between Wilbarger and Hardeman Counties, just west of Seymour, in Baylor County, and then west of south to or just west of Haskell, in Haskell County.

Cummins's original description of the Clear Fork is as follows:"

"The Clear Fork, or Middle Beds of the Permian, are composed first of bedded limestones, magnesian and earthy, which are sometimes carbonaceous enough to be

a Cummins, First Annual Report, Texas Geological Survey, 1889, p. I88. 
classed as stinkstone. These carry a large and characteristic fauna. They are in turn overlaid by clays and less fossiliferous limestones and shales. The limestones become less fossiliferous toward the top of the beds, the clays are both red and blue, the former color largely predominating. The red clays are in thick beds, and are in places interstratified with sandy shales. There are also beds of white, red, and spotted sandstones. Toward the top of the beds they become more sandy, and a few seams of gypsum occur, but not in the quantity in which it is found in the Double Mountain beds. There is also the peculiar kind of conglomerate which is found in the Wichita beds. The red clay contains vertebrate fossils, the bluish clay has copper, and the limestones have large quantities of invertebrate fossils.

"The fossils mentioned by Dr. White in his article heretofore quoted, published in the American Naturalist, were taken principally from the Clear Fork Beds. By reference to the list, it will be seen that it embraces both Paleozoic and Mesozoic types, and some that are characteristic and peculiar to the Permian. It will be seen from the list that the broad-shouldered Brachipods, which were so abundant in the Coal Measures, are wanting."

"These Clear Fork Beds"are composed of limestones, clay and shale beds, and sandstones.

"The limestones are mostly magnesian and carbonaceous, some of them being so largely impregnated with carbonaceous matter that when struck with a hammer they give off a peculiar odor, which has given such stones the name of 'stinkstone.' These limestones carry an abundant and characteristic fauna.

"The sandstones are not so abundant as in the Wichita Beds, and are not so massive, but are generally thin-bedded.

"The clays are blue and red, the red occurring in thick, heavy beds. The blue clays are in places copper-bearing. The conglomerate is similar to that found in the Wichita Beds, but is not so abundant, and is less compact.

"Toward the top the sandstones become more shaly, and the clays more sandy. There are also some beds of gypsum, but not in such abundance as is found in the Double Mountain Beds."

Gordon's first account of Clear Fork formation is included in his description of the Wichita formation, page ro. A more recent and more complete account by Gordon ${ }^{b}$ appeared in 1913 :

"Overlying the Wichita formation conformably are red and blue clays, sandy shales, and sandstones, including deposits of gypsum and a few beds of earthy magnesian limestone. These rocks were subdivided by Cummins into the Clear Fork and Double Mountain beds, but, as stated by that author, 'no attempt has been made to determine a definite line of division between the two,' and in view of the character of the sediments, it is evident that the determination of such a line, if it can be made at all, will require much detailed work. Hill proposed the term Brazos series to embrace all those rocks of Texas, Oklahoma, Kansas, and New Mexico between the top of the conformable Coleman division of the Carboniferous beds below (and) the base of the unconformable Cretaceous above,' but the suggestion has not been elsewhere adopted. According to Gould, these beds correspond to those in Oklahoma which he has termed, in ascending order, the Enid, Blaine, Woodward, Greer, and Quartermaster formations.

a Cummins, Second Annual Report, Texas Geological Survey, I890, p. 40I.

b Gordon, U. S. Geological Survey, Water Supply and Irrigation Paper No. 317, pp. 28, 29, 1913. 
"In the lower beds red and blue clays predominate, but the upper beds are characterized by an increase in the proportion of arenaceous constituents and also of limestone and gypsum. The sandstones and limestones are friable and, together with the clays, yield readily to eroding agencies and supply a large amount of detritus to the streams, which are heavily charged with the red sediments brought down by their tributaries. In the lower beds the gypsum occurs as thin layers and lenses in the clays. Beds of massive gypsum 2 to 3 feet thick crop out in the hills south of Quanah. At Acme, where the material is quarried, the deposit is from to to 20 feet thick. In many places fibrous gypsum fills cracks which cut the alluvial clays in every direction.

"The massive gypsum does not constitute persistent strata, but thins out or is replaced horizontally by clays or limestones. J. J. Cyrus, a well-driller of Quanah, states that the wells of that city derive their water from a porous limestone stratum at a depth of 75 feet and that no gypsum occurs in the overlying beds, which consist mostly of clay. A well put down a mile south of Quanah passed through a bed of gypsum at 40 to 65 feet and another at 75 to 83 feet, the latter apparently the equivalent of the limestone found in the city wells.

"Except where overlain by fluviatile deposits of Quaternary age, the Clear Fork and Double Mountain formations constitute the surface rocks west of the Wichita formation as far as the escarpment that marks the eastern extension of the Triassic in Texas.

"The age of these beds is generally recognized as Permian. Fossils are scarce and are confined chiefly to the limestones. The meager collections thus far made from these beds in Texas are not sufficient to warrant definite conclusions concerning them.

"Cummins has assigned to these beds a total thickness of 3,900 feet, i,900 feet to the Clear Fork and 2,000 feet to the Double Mountain. Only the lower beds of the formations are exposed in the Wichita region. Red gypsiferous shales and sands, with beds of gypsum and some limestones in the upper part, represent the formations as they appear here.

"The limestone (No. 3) [section 43 of this paper] is made up of several layers, some of which are composed largely of fragmental remains of vertebrates, including plates, spines, fish teeth, etc. The stratification of the argillaceous and arenaceous sediments is very irregular, the sandstones and shales grading into each other both vertically and horizontally. Moreover, there is a monotonous likeness in both the sandstones and the shales throughout the area, which, in the absence of persistent, clearly recognizable strata, renders the correlation of beds, except within very narrow limits, practically impossible.

"Some of the most prominent limestone divisions of the southern area persist, although in diminished thickness, as far north as Red River, perhaps farther. The limestones so well developed on Clear Creek, in the southwestern part of Throckmorton County, extend northward through Seymour, are crossed by Wichita River about 3 miles east of the Seymour-Vernon road, and are last seen on Beaver Creek, in the eastern part of Wilbarger County. The transition of limestone into sandstone is well marked in an exposure in the bluffs of the Salt Fork of Brazos River, about a mile west of Spring Creek post-office, in the northwest corner of Young County. A bed of limestone 3 feet thick and an overlying bed of blue shales 5 feet thick, both filled with fossils (chiefly Myalina permiana), are replaced within a distance of 200 yards by a light-colored cross-bedded calcareous sandstone having a maximum thickness of I $_{5}$ feet. The transition is rather abrupt in appearance, but the sandstone contains much lime and also some fossils. Farther along the limestone reappears as before. 
"The limestones of the Wichita formation are for the most part highly fossiliferous, though in many of the beds good specimens are hard to obtain. A list of the invertebrate fossils obtained from these beds has been published elsewhere. (See table 2, page ro6.) Collections of vertebrate remains have been made at various times in Archer and Baylor Counties. A list of localities where the earlier collections were made is given by Cummins. In many places the remains are found at the surface, having weathered out of the clays or lime beds. Certain strata, called the 'bone-beds,' have furnished most of the material. A chalky friable limestone exposed in a railway cut just west of Mabelle Station, in Baylor County, is filled with fragments of vertebrate remains allied to Eryops, mostly indeterminable. In a recent paper Williston announces the discovery of a new genus and new species of amphibian allied to Eryops, which he names Trematops milleri. This specimen is said to have been found on Craddock's ranch, near Seymour. The figure of the skull given by Williston shows a close correspondence to one found by the writer in the friable limestone at the railway cut near Mabelle, which was unfortunately broken and in part lost before opportunity was given for identification. It seems probable that both came from nearly the same horizon."

THE DOUBLE MOUNTAIN FORMATION.

Cummins's original account ${ }^{2}$ of this formation is as follows:

"The Double Mountain, or Upper Beds of the Permian, are composed of sandstones, sandy shales, limestones, red and bluish clays, and thick beds of gypsum. The limestones are quite earthy, and are often very full of the casts of fossils, the newer types largely predominating. The shales are often highly impregnated with common salt, and none of them are free from gypsum. The sandstones are red, gray, and spotted, and are generally very friable. The gypsum beds are numerous, and often very thick, and the seams of fibrous gypsum traverse and transect the clays and shales in every direction, ranging from paper-like seams to those ro inches in thickness, and often making a perfect network of seams. Toward the western boundary of these beds, the strata are much distorted and folded. It looks as if there had been a heavy lateral pressure from the west, crumpling the strata into short folds. In the gypsum, the folds are often only an inch or two across.".

"The beds ${ }^{\mathrm{b}}$ are composed of sandstones, sandy shales, red and bluish clays, and thick beds of gypsum. The limestones are generally of an earthy variety, and in places have many casts of fossils, the newer types being more largely represented than the older. The gypsum beds are numerous and many of them very thick. All the clays and shales are impregnated with gypsum, and many of them carry a large percentage of common salt.

"The sandstones are very friable, and are of various colors, red, white, and spotted."

The author has found it very difficult to draw any exact line between the Clear Fork and the Double Mountain, but is in agreement with Cummins that there is, west of the line described by him (Cummins), a decided change in the character of the sediments. This change is, however, rather gradually accomplished. As far west as Haskell there is a conglomerate very similar, both in character, thickness, and coloration, to the layer described as the

a Cummins, First Annual Report, Geological Survey Texas, I889, p. 188.

b Cummins, Second Annual Report, Geological Survey Texas, 1890, p. 402. 
Wichita conglomerate. ${ }^{a}$ It is traceable in the breaks of the small creeks which form the main exposures in the region. North of the Big Wichita River this layer is very persistent, and forms a good reference horizon (see plate 8 , fig. 2 ). Above it are 100 to 200 feet or more of red clays, sandstones and conglomerates, carrying typical Clear Fork vertebrates. (Here are the Cacops beds of Williston, Lysorophus beds, etc.) On the north side of the Big Wichita, the beds above the Wichita conglomerate appear as prominent bluffs capped with a heavy conglomerate or sandstone. West of Haskell the land is level and the rocks are concealed by a considerable thickness of surface soil, but at Sagerton, some I2 miles southwest of Haskell, the bluff shows at its foot cleaner clays, with little conglomerate and a much more regular and even stratification; at this place appear also the first layers of satin spar which are so characteristic of all the Permo-Carboniferous beds above the Clear Fork. The gypsum which occurs in the Clear Fork Beds is in local patches, and far from abundant. Evidently there was a serious change in the conditions of sedimentation between the Clear Fork and Double Mountain time. All along the line drawn by Cummins separating the formations, the difference between the beds may be recognized within a mile or more by the characters described.

OCCURRENCE OF FOSSIL VERTEBRATES.

Vertebrate fossils are not found through all of the Wichita formation, but have been collected from the whole thickness of the Clear Fork. If a line be drawn south from the Big Wichita River, a little east of Holliday in Wichita County, east of Archer in Archer County, and continuing for an undetermined, but not great, distance south of the latter place, it will mark the east line of the occurrence of vertebrate fossils in the Wichita. ${ }^{b}$ A considerable thickness of deposits only to be reckoned as belonging to the Wichita lies below the beds mentioned.

Fossils occur in the Clear Fork to its upper limit, for Cummins reports finding bones on Paint Creek, a few miles south of Haskell. North of Haskell vertebrates have been found for only a few miles west of the road from Seymour to Vernon.

Any attempt to describe the beds in which the vertebrate fossils occur is fraught with the greatest difficulty, as they are in the highest degree discontinuous; only the fossil hunter, whose success may depend on following a single layer, can realize the impossibility of tracing any one of the layers of sandstone, clay, or conglomerate for more than a very short distance. Perhaps the best general idea of the beds may be gained by realizing that the limestones outcrop with a strike a little east of north, and a gentle westerly dip; though they can not be traced continuously for more than a mile or so, they indicate the general lie of the beds, which are in general

a Case, Bull. Amer. Mus. Nat. Hist., vol. xxirr, p. 662, 1907.

${ }^{b} \mathrm{~A}$ recent letter to the author from Dr. C. L. Baker of the University of Texas reports the discovery of a small skull of Cardiocephalus from Halsell in central western Clay County. 
roughly parallel with them. Between and above the limestones lie heavy beds of red clay, with local developments of cross-bedded sandstones, conglomerates, patches of blue clay, etc., in inextricable confusion. In the valley of the Little Wichita, just beyond the beginning of the breaks south of Dundee, an outcrop of shaly sandstone may be traced in a direction totally at variance with the general strike of the limestones. In the spot mentioned, the strike of the sandstone is almost directly northwest-southeast, and is not in accord with the strike of the beds above and below them. Numerous examples of this kind could be cited. (See plates 5-IO.)

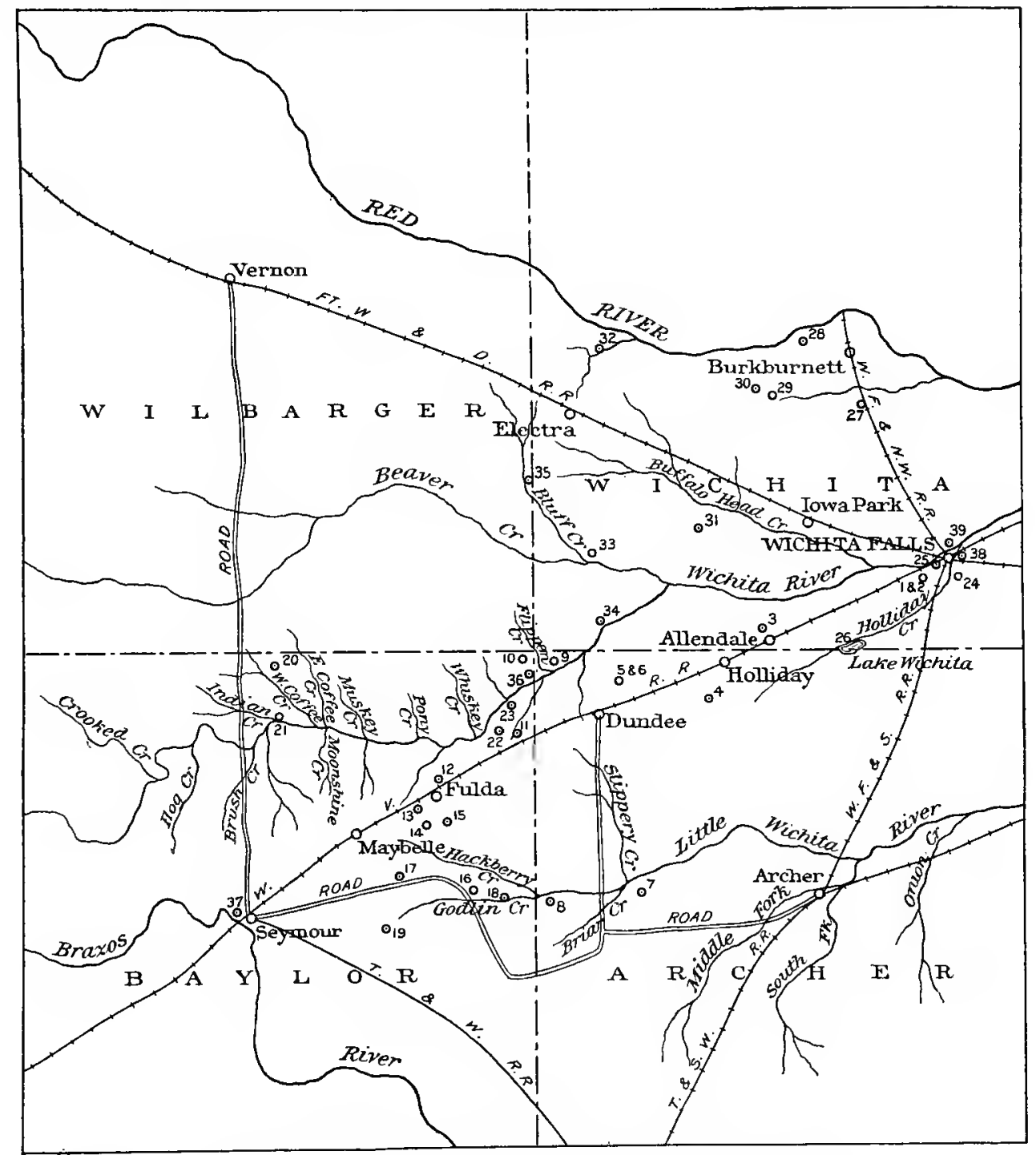

FIG. 4.-Map showing location of sections given in text.

SECTIONS.

The following series of sections taken by various workers in the Texas area will give some idea of the general character of the beds. Their location is shown in fig. 4. As in other localities in the Red Beds of the Permo- 
Carboniferous and much of the Triassic in this country, sections taken at one locality are not to be depended upon as representing the succession at another, even within a quarter of a mile.

Section I.-Taken 2 miles west of Wichita Falls (Case). Surface covered with rough ironstone concretions and rounded pebbles of quartzite.

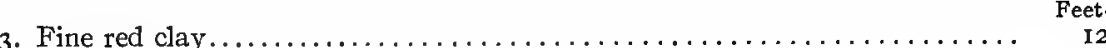

2. Purple sandstone; shaly above; gray and more massive below........... 6

I. Red clay; bottom not seen.

Section 2.-Taken 2 miles west of Wichita Falls (Cummins).

2. Red clay, with nodular iron ore

Feet:

I. Sandstone; thin-bedded...

Section 3.- Hill about I 2 miles west of Wichita Falls (Cummins).

4. Red Bed clay....................................... 20

3. Conglomerate, fossiliferous......................... I

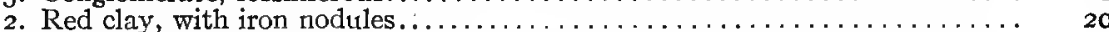

I. Sandstone, thin-bedded............................. 4

"It must be remembered that the conglomerate mentioned in the sections is the peculiar Permian conglomerate, composed of small round pieces of iron ore and clay cemented together by iron." a

This statement applies only to the sections by Cummins in the eastern exposures of the Wichita, not to the conglomerate mentioned by Case in the western (higher) exposures of the Wichita, and in the Clear Fork.

Section 4.-Taken 3 to 4 miles southwest of Holliday (Case).

4. Coarse brown conglomerate, overlying and replacing a shaly or massive

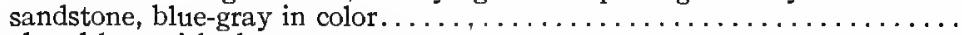

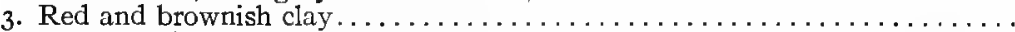

2. Brown and gray shaly sandstone and pea conglomerate (Cummins's "pecu-

liar conglomerate" $)$; some fossils . . . . . . . . . . . . . . . .

I. Red clay, bottom not seen.

Feet.

5

Section 5.-Corn Hill, or Tit Mountain, a little northeast of Dundee (Cummins).

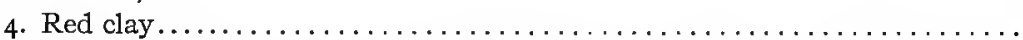

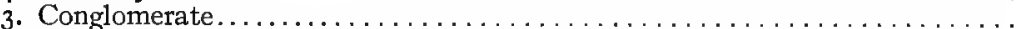

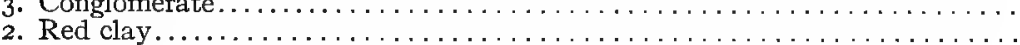

I. Thin-bedded sandstone.

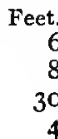

Section 6.- Taken I mile west of Corn Hill (Cummins).

2. Thin-bedded sandstone.

Feet.

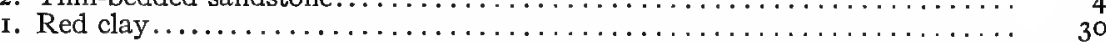

Section 7.- 3 miles east of the Dundee-Archer road, I mile or so south of the Little Wichita (Case).

5. Shaly sandstone, overlain by local patches of heavy, brown conglomerate.. 5 to

4. Red clay............................ 5 to Is

3. Shaly sandstone; gray, changing to red..................... 5

2. Thin layer of pea conglomerate, "peculiar conglomerate"........... 2 to 3

I. Red and variegated clay, with local beds of light bluish-green clay; carrying amphibian and fish bones; bottom not seen.

Section 8.--Taken on east or south side of Godlin Creek, just beyond its juncture with the Little Wichita (Case).

3. The capping rock a sandstone of varving thickness, underlain by the usual conglomerate, which is here quite thick.

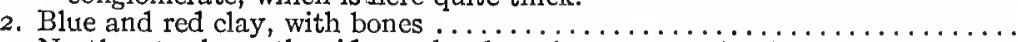

I. Northeast, along the ridges, the clay plays out, and a lower conglomerate comes up to the base of the sandstone. On the east side of the ArcherDundee road the sandstone becomes very heavy for a short distance.

a Cummins, Second Annual Report, Geological Survey Texas, I 890, p. 403. 
Section 9.-Northwest corner of Archer County (Gordon).

"Outcrops of limestone are found on the boundary between Archer and Baylor Counties. Some beds of the limestone at the top of the escarpment on the west side of Horseshoe Lake. The limestone is earthy, dark blue, and weathers to a dark brown or black. The limestone is underlain by 4 feet of blue clay, and this by roo feet of red concretion-bearing clay, with a limited development of red and white limestone. From this corner west the stratification is more regular; blue shales alternating with predominant red, and an occasional bed of impure limestone."

Section Io.- Taken near the Bar X Ranch crossing of the Big Wichita. Northeast corner of Baylor County (Case). Several ledges of hard limestone separated by varying thicknesses of blue shale and red clay. Section II.-Taken near the railroad just west of the line between Baylor and Archer Counties (Case).

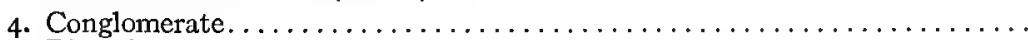

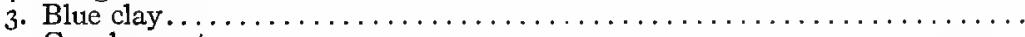

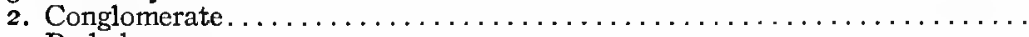

I. Red clay.

Feet.

Section I2.- Northeast of Fulda, about 2 miles (Case).

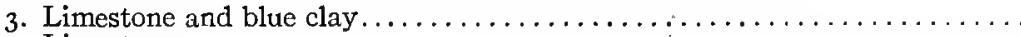

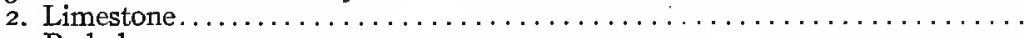

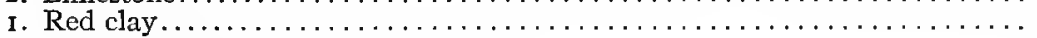

Feet.

Section I3.-Taken at Fulda (Case).

2. Conglomerate .................................. 6 inches.

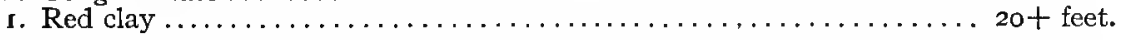

Section 14.-Taken in large breaks I mile southwest of Fulda (Case).

3. Red clay, with iron concretions ....................... 6 to 8 feet.

2. Light gray shaly sandstone (Fulda sandstone) $\ldots \ldots \ldots \ldots \ldots 2$ inches to 2 feet.

I. Variegated clay; uniformly, from above downward, greenish blue, dark red, bluish, purple; gray, scarce fragments of bone in isolated patches of blue clay................................................

The same section is found I mile north of Fulda, but the sandstone is more massive, and, in places, harder. Approximately the same section is found also 5 or 6 miles west of Fulda, and traceable to the Little Wichita.

Section I5.-About 2 miles directly south of Fulda (Case).

5. Coarse conglomerate.

4. Light red, fine-grained clay, mixed with pebbles...............

3. Dark-red clay, with coarse, rough iron concretions............... 20

2. White sandstone (red streaks), persistent over large area............ I to 3

I. Red, white, and yellow clays; bottom not seen.

Section I6.-About I mile north of the bridge over Godlin Creek, on the Archer-Seymour road (Case).

5. Brown limestone; forms a prominent shelf . . . . . . . . . . 6 inches.

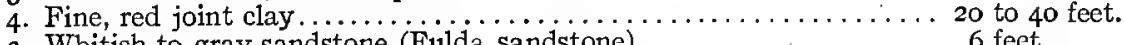

3. Whitish to gray sandstone (Fulda sandstone) ...............

2. Brown limestone, filled with small bones; forms a second shelf...... 6 inches.

1. Red clay; bottom not seen.

Section I7.-About ro miles west of section 16 . This is the section of a high hill; about 3 miles southwest of the old Crewthird place, and almost directly south of the town of Maybelle (Case).

5. Light yellow limestone (the same limestone appears on the hills crossed by the Archer-Seymour road a mile or so west of the bridge over the

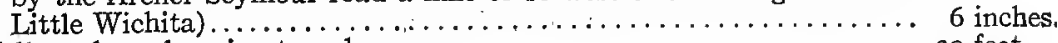

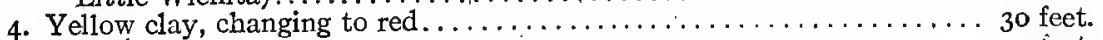

3. Red clay........................................ 20 teet.

2. Sandstone, variable red and white, shaly and massive.......... 4 feet.

I. Red clay; bottom not seen. 
Section I8.-Less than a mile east of the bridge over the Godlin Creek on the Archer-Seymour road. Near the old Ek. Brown place. There is an oil-prospecting derrick near the spot now (I913) (Case).

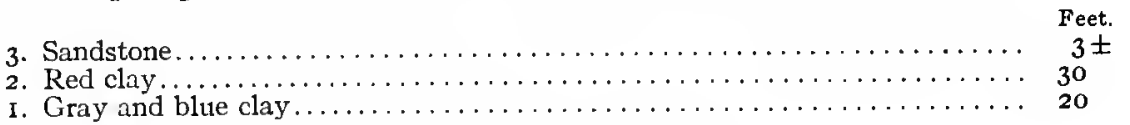

Section I9.-Near the head of Godlin Creek (Case).

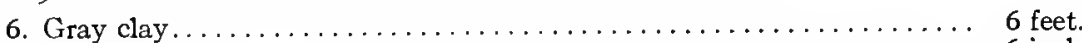

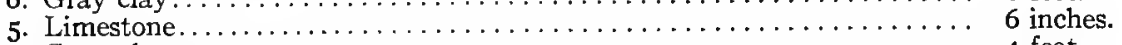

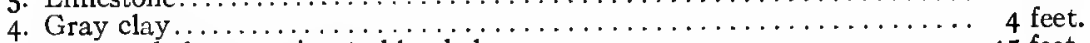

3. Deep red clay, turning to blue below............................... 45 feet.

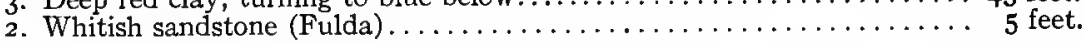

I. Red clay; bottom not seen.

Section 20.-A generalized section near the Seymour-Vernon road, north of the Big Wichita (Case).

6. Red and blue clay, and sandstone .................60 to 1oo feet.

5. Purplish-green, fine conglomerate (Wichita) ................

4. Red clay, with calcareous nodules......................

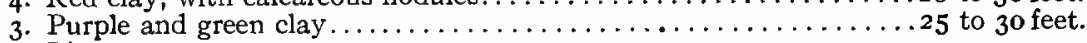

2. Limestone:

$a$. Thin limestone, broken into small blocks $\ldots \ldots \ldots \ldots \ldots \ldots, \ldots 2$ inches.

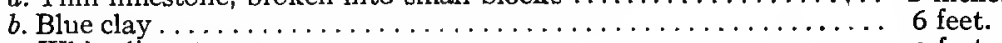

c. White limestone.............................. 2 feet.

I. Blue and gray clay; bottom not seen.

Section 21.-Bluff 2 miles east of Seymour-Vernon road. North side of the Big Wichita (Cummins).

Middle of the section red and concretionary clay and sandstone. The lower two-thirds red and blue shale, alternating with beds of limestone. Locally the thin-bedded limestone shades into more massively bedded limestone.

Section 22.- South side of the Big Wichita, 4 miles west of the east line of Baylor County Cummins).

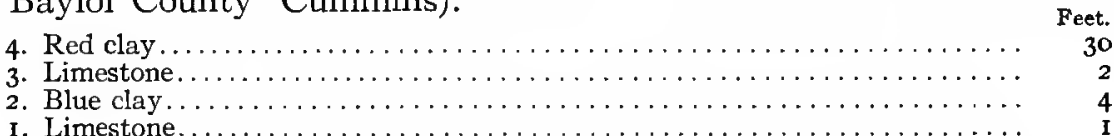

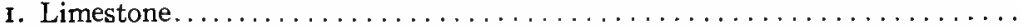

Section 23.- South side of the Big Wichita, 2 miles west of the east line of Baylor County (Cummins).

Red clay, with nodular concretions

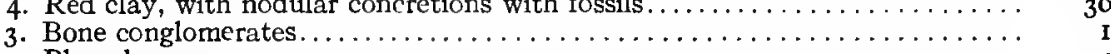

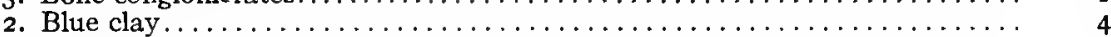

I. Conglomerate (iron ore),

Section 24.-I I/2 miles southwest of Wichita Falls, a low bluff facing west and south follows the east side of an irrigation canal (Udden).

"This bluff consists of 5 feet of red and blue shale. There is also some conglomerate. The sandstone is typical of this region. It consists of mostly white and subangular quartz, but with some red and pink grains. It is frequently cross-bedded, and the cross-bedded layers alternate with thin, straight layers, lying horizontally. Some of these show extended surfaces, almost perfectly plain and smooth. Some spherical concretions were noted in which the grains of sand were cemented together with calcite, or with oxides of iron and manganese. The thickest homogeneous or unstratified layer noted was 2 feet. Under the sand in some places and interbedded with the lower part of the sand in another place were layers of conglomerate mostly less than a foot thick. This consists of lumps of limy and marly materials and lumps of clay, mostly from one-half to one-third inch in diameter. The shale is red, with bluish-white streaks and blotches. In one place it was cut by a vertical vein of hard, red calcareous material one and one-half inches thick." 
Section 25.-In the south bank of the Wichita River, about 0.75 mile southwest from the Fort Worth and Denver Railroad bridge, the bed rock is exposed for a considerable distance, and extends up into the bluff (Udden). The exposed section is as follows:

7. Thin-bedded red sandstone of fine texture, consisting of straight, smooth, and persistent layers from one-eighth to one-half inch thick.............

6. Red shale, with thin blue layers containing streaks of conglomerate, consisting of calcareous concretions mixed with lumps of clay, both kinds averaging one-fourth inch in diameter.

5. Red shale, containing scattered concretions of from one-third inch to 3 inches in diameter; many of the largest concretions have an irregularly mammil-

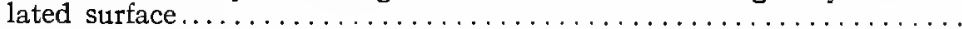

4. Sandy brown shale.

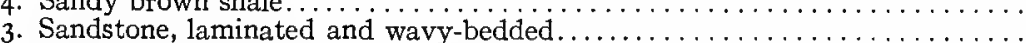

2. Shale, brown and blue, in places consisting of lumps, as if brecciated, or as if

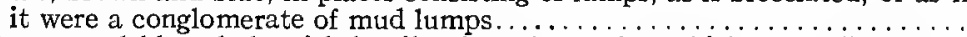

I. Brown and blue shale with lentils of sand, one foot thick, extending down below water level in the stream.

Section 26.--Near the pavilion, at the north end of Wichita Lake (Udden).

The strata seen consist of:

4. Gray sandstone.

Section 27.-About 4 miles south of Burkburnett the Wichita Falls and Northwestern Railroad bed is cut into a low hill a mile south of the main creek running east into the Red River (Udden). The west bank of this cut shows some cross-bedded sandstone which lies in an old channel evidently cut into the red clay by the currents which deposited the sand. It appears that the current was shifted northward, as there was a greater filling-in of sand on the north side. The current must have been thrown back and forth, for along one plane in the main sand deposit on the north side it is clear that the sand below this plane was eroded before the overlying sand was deposited. Later the entire channel was filled with red clay. (See fig. 5, p. 39.)

Section 28. - In the Red River bluffs, on the A. A. Durfee survey, almost due north from Iowa Park, outcrops of the Wichita beds are seen for a distance of some 2 miles (Udden). A section was taken where the bed-rock is highest, and this is as below:

10. Dark red sandy shale, with seams of dark red sandstone from to 2 inches thick Feet.

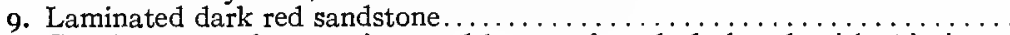

8. Conglomerate of concretions and lumps of mud, dark red, with thin inter-

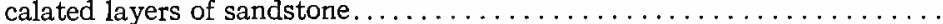

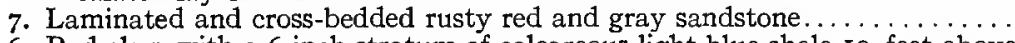

6. Red clay, with a 6-inch stratum of calcareous light blue shale io feet above its base; the red clay contains blotched gray concretions a half-foot in

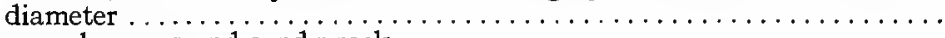

5. Gray calcareous and sandy rock. $\ldots \ldots \ldots \ldots \ldots \ldots \ldots \ldots \ldots \ldots$

4. Red shale, in part sandy 3. Calcareous sandstone, with fragments of fossils, in places with many sizes

3. Calcareous sandstone, with fragments of fossils, in places with many sizes
and kinds of concretions; the lower side of this stratum has combs or

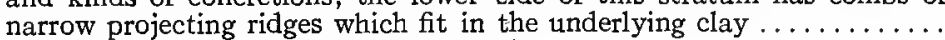

2. Variegated shale, with calcareous concretions ................ 6

I. Red shale .......................... I

The calcareous seam in No. 6 of the above section was noted 0.5 mile farther west, in the bluff. 
Section 29.-In the west side of the road running north and south along the east side of B. S. \& F. survey, I mile west of School No. 9, and about 9 miles north and 2 miles west of Iowa Park, there is a thin shell of light gray limestone overlying some gray shale (Udden). This limestone contains unrecognizable organic fragments throughout, and a small coral and a fish-scale were noted. It changes into a sandy calcareous rock in a short distance to the northeast. A thousand feet to the northeast from this place there is an exposure in the east bank of the creek, which probably lies 20 or 30 feet below the above limestone. In this exposure is seen a typical instance of contemporaneous erosion in the Wichita formation. A thin gravel of washed concretions lies on a contemporaneously eroded bed of red shale, and over this, 0.5 foot of shale and then 3 feet of sand, with another streak of soft conglomerate. (See fig. 6, p. 39.)

Section 30.- In the south end of the T. E. \& L. Co. survey abutting on Red River, about $21 / 2$ miles west of School No. 9 and 9 miles west of Burkburnett. A section appearing in the right bank of Calvary Creek is as follows (Udden):

6. Sandstone and concretion conglomerate $\ldots \ldots \ldots \ldots \ldots \ldots \ldots \ldots \ldots$

5. Ashen gray and red shale. .

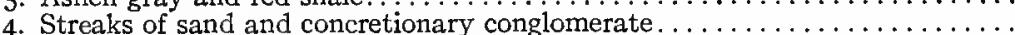

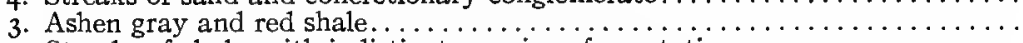

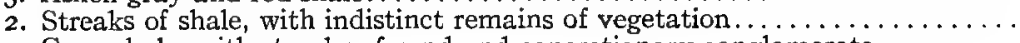

I. Gray shale, with streaks of sand and concretionary conglomerate..........

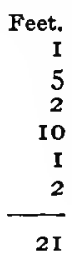

Section 3I.-Near the north boundary of the C. T. R. R. Co. survey abutting on Wichita River, about 6 miles west and r.25 miles south of the railroad station at Iowa Park, there is an eroded bluff showing the following section (Udden):

4. White sandstone, in part cross-bedded ....................

3. Red clay with many concretions and here and there some sandy streaks....

2. Red sandstone, with cross-bedded structure; terminates somewhat abruptly

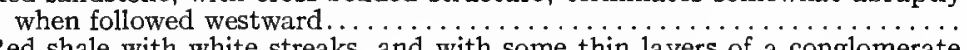

Feet.

I. Red shale with white streaks, and with some thin layers of a conglomerate

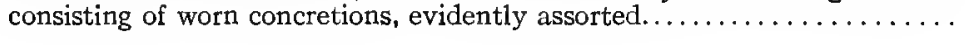

The lower sandstone, or a sandstone having the same level in the red shale, runs south in a low escarpment for almost a mile, and is again well exposed in some bluffs just south of the main wagon road. At this point it was seen to contain an impression of a fern leaf, like Pecopteris tenuinervis F. and W.

Section 32.-In block 314 of the Waggoner Colony survey, about 7.5 miles north and 4 miles east of Electra, in the right bank of China Creek, is an exposure of red clay and sandstone, which shows unconformities in bedding (Udden). Farthest east is a bank of red clay, some 30 feet high, and this is capped for most of its length by several feet of sandstone. At its eastern edge this sandstone terminates against a rising slope of the clay, like the bank of an old channel. At the west end of the exposure two rising sandy layers have been cut off in the excavation of a contemporaneous channel, or hollow, which later has been filled with sand. (See fig. 7, p. 39.) 
Section 33.- In the bluffs on the north side of Beaver Creek, on the Houston and Texas Central Railroad Company survey No. 35, about 7.5 miles south and 2.5 miles east of Electra, the following section was noted (Udden):

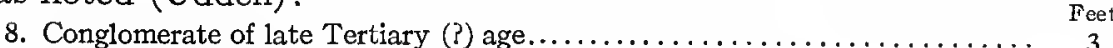

7. White sandstone, top of Wichita beds in this section $\ldots \ldots \ldots \ldots \ldots \ldots \ldots, 7$

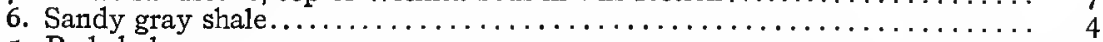

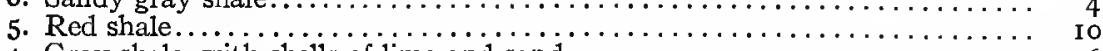

4. Gray shale, with shells of lime and sand ................... 6

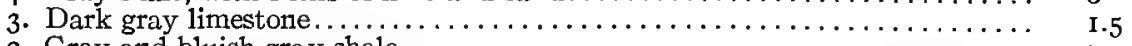

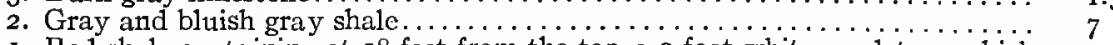

I. Red shale containing at 18 feet from the top a 9 -foot white sandstone which runs out in the section in a short distance to the east............ 33
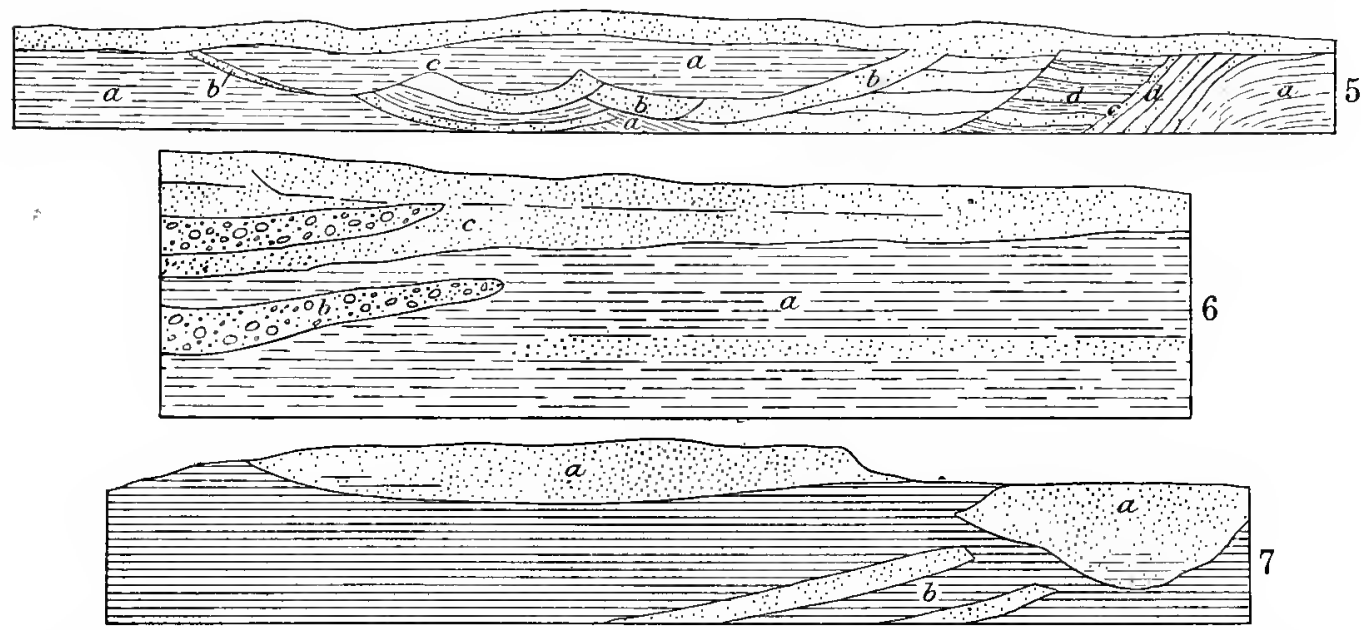

FIG. 5.-Section in cut along the Wichita Falls and Northwestern Railway, 3.5 miles south of Burkburnett, Wichita County: $a$, red shale; $b$, cross-bedded sand; $c$, erosional unconformity; $d$, alternating layers of silt and sand. (From Udden.)

FIG. 6.-Wichita beds exposed in bank of creek in Central Texas Railway Company survey, 9 miles north and 2 miles west of Iowa Park, Wichita County: $a$, shale; $b$, conglomerate; $c$, sandstone. (From Udden.)

FIG. 7.-Exposure in right bank of China Creek in Block 314, Waggoner Colony survey, 7.5 miles north and 4 miles east of Electra, Wichita County. Two sandstone beds, rising from left to right, have been beveled off; some clay was later deposited on the eroded slope; the depression was later filled with sand, which overlaps at the right. (From Udden.)

Section 34.- In the north bluff of the Wichita River, near the west line of the L. T. Miller survey, about I I miles south and I mile east of Electra, is the highest single exposure of the Wichita beds in Wichita County (Udden). It measures I30.5 feet, and is as below:

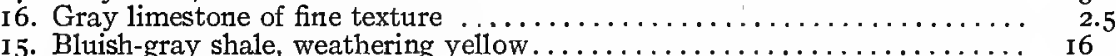

I4. Sand and shale, purplish in color.................................. 3

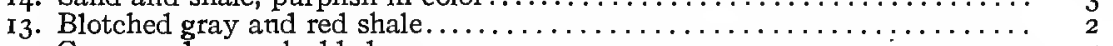

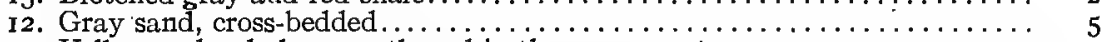

II. Yellow and red clay, mostly red in the upper part ................ ${ }_{2} 3$

Io. Dull red, silty, soft sandstone, mingled with gray layers ........... 5

9. Gray, muddy shale, cross-bedded sandstone and conglomerate consisting

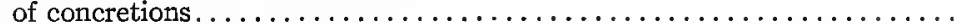

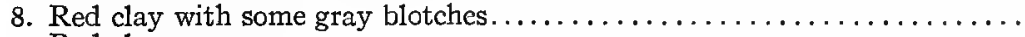

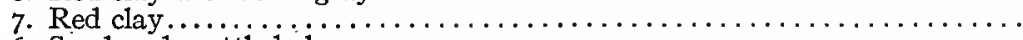

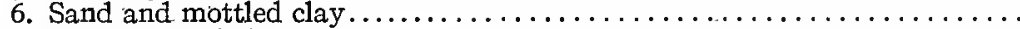

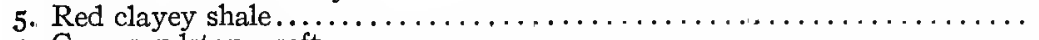

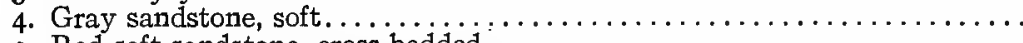

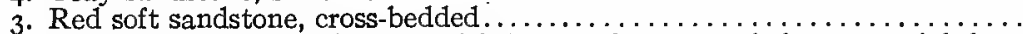

2. Blotched gray and red shale, with layers of gray sand, from one-eighth to

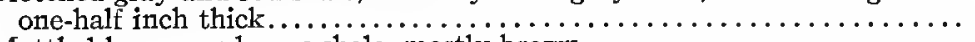

I: Mottled brown and gray shale, mostly brown................ I I 
Section 35.-A section near the northwest corner of the Houston and Texas Central Railroad Company survey No. 27, about 4 miles south and 2 miles west of Electra (Udden).

3. In a well bored for water near this place a dark gray thin limestone was penetrated at the depth of about 45 feet. Fragments of this limestone were seen on the old dump, and it was clearly identical with the Beaver Creek limestone. The curb of the well is about 20 feet under a calcareous stratum containing fragments of vertebrate bones, capping a low bluff near this place. The beds between this layer and the limestone in the well consist of red and blue shales, with some sandy layers and streaks of black shale. This shale contains some black impressions of plant leaves. Calcareous sandstone or a concretionary layer caps the adjacent low bluffs.........

2. Red and blue shale, the latter with plant remains, partly exposed, and also

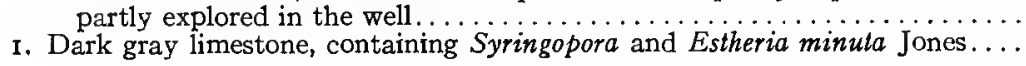

Section 36.-Bluff on west side of Horseshoe Lake, Wichita County, Texas (Gordon).

I I. Limestone, hard, dark blue, brown on exposure, cavernous............

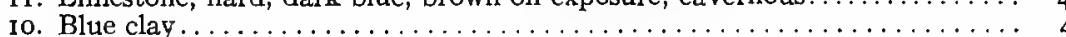

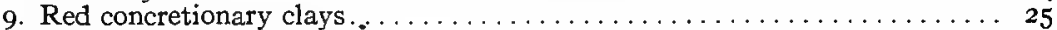

8. Soft red shaly sandstone $\ldots \ldots \ldots \ldots \ldots \ldots \ldots \ldots \ldots \ldots \ldots \ldots \ldots \ldots \ldots$

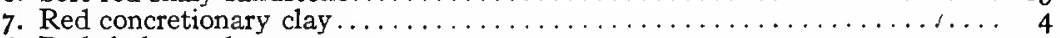

6. Red shaly sandstone.............................. 9

5. White and red variegated sandstone, more massive than Nos. 6 and $8 \ldots \ldots 6$

4. Nodular clay ("conglomerate") $\ldots \ldots \ldots \ldots \ldots \ldots \ldots \ldots \ldots \ldots \ldots$ I

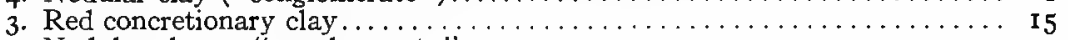

2. Nodular clay or "conglomerate" ......................... 33

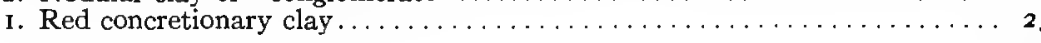

Section 37.-Seymour, Texas (Gordon).

20. Light reddish sandy soil at surface, underlain by dark-red sandy soil. . 20 to 25

19. Blue shale, with thin ledges of magnesian limestone............. 6

18. Limestone in massive beds, passing horizontally into shaly beds ........ 5

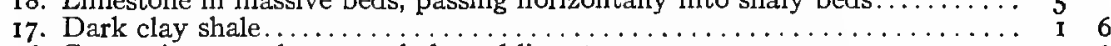

16. Concretionary calcareous shale and limestones................. o o 6

15. Limestone in two massive ledges separated by 1 to 4 inches of blue clay shale. 3

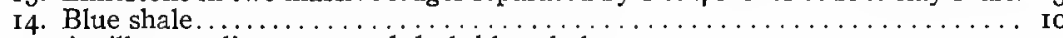

I3. Argillaceous limestone and dark blue shale................. 3

12. Limestone with varying proportions of shale................. 4

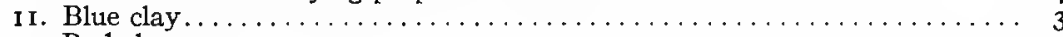

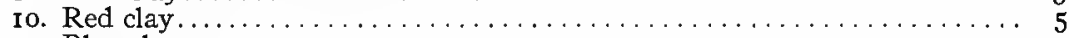

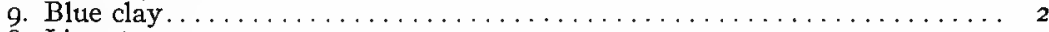

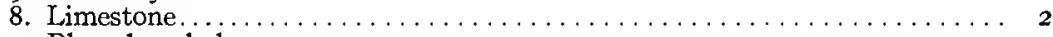

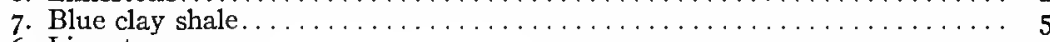

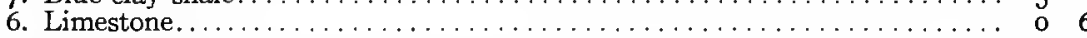

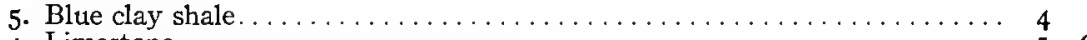

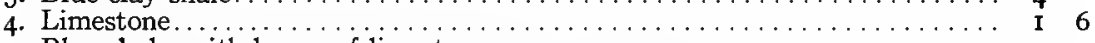

3. Blue shale, with lenses of limestone..................... 3

2. Blue clay shale, interbedded with thin limestone............... 2

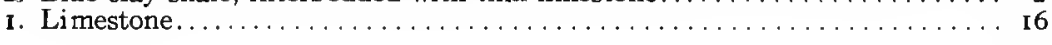

Section 38.-At the southeast corner of the Walker-Harvey survey, 2.5 miles northeast of the Union Station at Wichita Falls, a sandstone I 2 feet thick is seen in the low bluff. This sandstone rests on some 20 feet of red and gray shale (Udden).

Section 39.- In the cut of the Missouri, Kansas and Texas Railroad, on a hill about I mile east of Wichita Falls, a sandstone is exposed which is composed of alternations of flat laminated layers and cross-bedded layers from 2 inches to a foot thick. Some of the 11ppermost layers are black from impregnations of iron and manganese oxide (Udden). 
Section 40.--Section in the east bluff of Wichita River, 0.75 mile northwest of Byers, Clay County (Udden).

4. Gray sandstone, with a 6-inch layer of concretionary conglomerate, greenish-

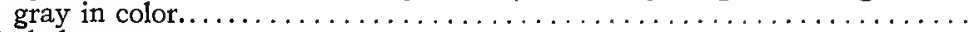

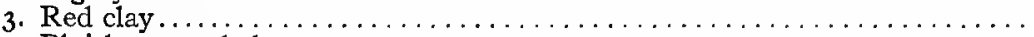

2. Bluish-green shale. ...........................

I. Talus

Feet.

Section 41 . - In a low bluff facing east, at a point about 3 miles west of Henrietta, Clay County, 0.5 mile south of the Fort Worth and Denver Railroad, there are some beds that have been explored for copper, which occurs in the forms of malachite, azurite, and gray copper sulphide (Udden). The copper has accumulated mostly on the under surface of some carbonaceous clay bands, in cavities once filled with plant remains, and also in some joints in sandstone. The section exposed, partly in an old excavation, is as follows:

9. Sandstone. $\ldots \ldots \ldots \ldots \ldots \ldots \ldots \ldots \ldots \ldots \ldots \ldots \ldots \ldots \ldots \ldots \ldots$

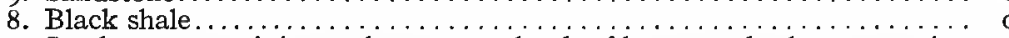

7. Sandstone containing carbonaceous shreds of leaves and other vegetation

6. Black shale, with a more or less continuous infiltration of copper ore against its lower surface. . . . . . . . . . . . . . . . . . .

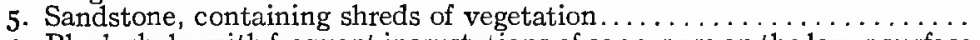

4. Black shale, with frequent incrustations of copper ore on the lower surface

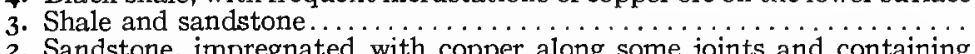

2. Sandstone, impregnated with copper along some joints and containing some impressions of tree-stems and other remains of vegetation, which are partly filled with copper ore $\ldots \ldots \ldots \ldots \ldots \ldots \ldots \ldots \ldots \ldots \ldots$

I. Shale............................. I

\begin{tabular}{ll} 
Ft. & In. \\
8 & \\
0 & 4 \\
0 & 6 \\
0 & 4 \\
0 & 6 \\
0 & 2 \\
2 & \\
\\
2 \\
I+ & \\
\hline I4t & 8
\end{tabular}

Section 42.-About 3 miles northeast of Wichita Falls, in Clay County, a low bluff, facing westward, runs for almost a mile in a general north and south direction (Udden). At the north end the strata exposed in this escarpment form an isolated butte. The section in this butte is as follows:

5. Gray sandstone, soft and homogeneous in some places, in other places concretionary, cross-bedded, or cemented by interstitial lime to a hard rock; this sandstone forms the cap of the escarpment; maximum thickness.....

4. Gray and blotched brown shale, sandy in places, and containing calcareous

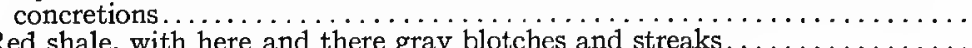

3. Red shale, with here and there gray blotches and streaks. . . . . . . . . . . .

2. Gray sandstone, much cross-bedded, partly straightly and thinly laminated.
I. Shale, gray and brownish, with many dark, calcareous concretions.........

Feet.

Section 43.-Cassil Hollow, 2.5 miles south of Fulda, Texas (Gordon).

6. Sandstones, thin-bedded, shaly, with a fine exhibition of ripple-marks; represents the top of the section and grades into No. $4 \ldots \ldots \ldots \ldots \ldots \ldots$

5. Blue and yellow laminated clay and sandy shale, grading horizontally into white shaly sandstones, same as No. 6 ; the plants were found in a thin

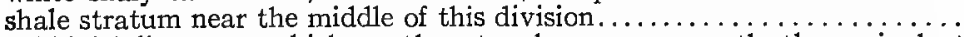

4. Hard bluish limestone which weathers to a brown; apparently the equivalent of a limestone which outcrops on the Wichita nearly due north from this locality at the Bar X Ranch; contains an abundance of fragments of vertebrate remains, but all in such a comminuted condition as to be inde-

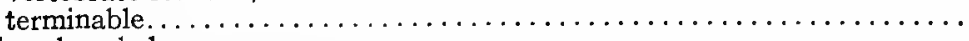

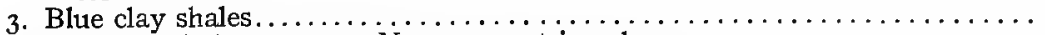

2. Red clay shales; same as No. 3 , except in color....................

1. Gray sandy shales and sandstones to bottom of ravine...............

Feet. 


\section{CLIMATIC VARIATIONS RECORDED IN THE PERMO-CARBONIFEROUS BEDS OF TEXAS.}

It is apparent from the foregoing that the Red Beds of Texas terminated on the east in a limestone-forming sea. There was over north-central Texas and central Oklahoma a great, flat area bordering the eastern sea. This area received abundant terrestrial deposits from higher lands to the north and west, but was of such slight elevation that it was subject to local inundations, both by marine waters, due to slight oscillations of level, and by fluviatile waters during humid phases of the climatic oscillations. Within the limits of the eastern sea there are limestones with frequent intercalations of sandstone and sandy shales, and with occasional beds of clay, such as would occur in the deposits of a low and partially or recurrently flooded region. That the whole area was not subject to large movements due to periodic changes of level of considerable magnitude is shown by the badly mixed and discontinuous character of the beds. No prevailing continuity of the beds can be traced, but a study of sections I, 2, 8, and others (pp. 34-4I) shows a considerable thickness of red clay and sandstone as the first dominant series of deposits in the lower Wichita. One thing is apparent in both Texas and Oklahoma: the limit of red color transcends the beds far east of where the clastic material gives place to organic deposits and is noticeable for a considerable distance in the limestones.

The most generally accepted hypothesis for the explanation of the presence of a red color in various deposits regards it as due to the mature weathering of iron-bearing rocks in a fairly humid region, with alternations of relative drought and humidity. There is nothing in the Red Beds of Texas to oppose this hypothesis or to support the alternative hypotheses that the color is due either to the oxidation of the iron subsequent to its deposition or to the dehydration of a limonite by the pressure of superincumbent layers, at least so far as the author has been able to determine. It is here accepted as the working principle in the study of the climate of the region and period.

EVIDENCE OF CLIMATIC CONDITIONS IN WICHITA TIME.

Few plant remains have been recovered from the eastern (lower) exposures of the Wichita, and while this is not positive evidence of the absence of vegetation during the first part of the period, the rarity of the remains lends weight to the suggestion given by the prevailing red color, of a lack of carbonaceous débris in the deposits.

While conglomerates are not lacking in the lower Wichita, they are not of the same character as those appearing farther to the west and higher in the series. The first conglomerate above the lowest series of Red Beds is described by Cummins as a "peculiar conglomerate," consisting of fragments of clay and iron ore, cemented by iron. This conglomerate is constantly referred to in my notes as the "pea conglomerate." Gordon interprets it as formed of fragments which have been broken up by wave action and re- 
cemented, but I am inclined to think that it may be explained otherwise. The "peculiar conglomerate" consists of small pebbles of about the size of a large pea, mostly a light brown clay ironstone, frequently concretionary in character, or weathering in concentric layers. The cement is limonitic. For the purposes of this paper it may be best to refer to it hereafter as the limonitic conglomerate. This conglomerate appears in sections I, 2, 4, and 7 , but does not appear again as a bed of any extent farther west, i.e., higher in the series. It must not be assumed that its appearance in the sections mentioned indicates a continuous bed between them. It is altogether probable that it does not, and in several places the recurrence of the same material is demonstrable.

The iron of secondary deposits is taken from the original minerals in the zone of weathering (according to Van Hise and others), either by direct conversion of the iron into ferric oxide, insoluble except in the presence of $\mathrm{CO}_{2}$ or humic acids, or by conversion into iron carbonate and then into limonite or other compounds. Limonite is formed from the carbonate by the action of oxygen in limited quantities, and is deposited below or near the water-level, where high oxidation is not likely to occur.

We may be certain that the red clays of Texas, with their ferric oxide, were deposited in the sea, or other bodies of water, in the condition in which they now occur, and are not due to subsequent dehydration or decarbonation, because (I) the color is uniform throughout; (2) because there is a solidity and density in the clays, and a lack of filled seams and veins, which would be impossible after such changes, which involve a decided decrease in volume; and (3) because the red color transgresses into the limestones and sandstones with marine fossils. The ferric condition of the iron may be due to either the original formation of the ferric oxide from the iron-bearing minerals or to the oxidation of carbonates in the course of prolonged transportation over semiarid or, at least, well-exposed flats previous to deposition.

The presence of limonite seems to indicate a higher level of the groundwater of the flats, for under such conditions the hydrated oxide derived from the carbonate would not be so likely to make long journeys exposed to the oxygen of the air. Thus we have an indication of a local increase in humidity during an interval of time represented by the limonitic conglomerates and associated light-colored clays and sandstones. The following statement from Barrell a bears directly upon this point:

"Sediment carried by rivers is subject to oxidation both while in transit and after deposition on the surface of the flood plain, until its burial by overlying layers carries a stratum below the level of ground-water. Where the ground-water level is coincident with or higher than the surface, organic matter accumulates and deoxidizing processes take place. A certain fraction of delta deposits, depending on the proportion of back swamps and coastal swamps, therefore show colors ranging from green to blue, according to the state of the iron oxide, and from white through

a Barrell, Bull. Geol. Soc. Amer., vol. 23, p. 4I6,\$19I2. 
gray to black, according to the amount of carbon. But over the larger portion of the delta the iron of the soil is more or less completely oxjdized during the season of dryness, and the corresponding colors-yellow, orange, red, or brown-are in evidence. The ratio of these oxidized and deoxidized sediments varies with the flatness of the delta and the character of the climate."

The conditions which permitted the deposition of the limonitic conglomerates did not long endure, for the beds are thin and there is a succeeding thickness of 100 or more feet of red clay, with beds of red and gray sandstones. As shown above, the red deposits can only mean regions and periods where and when large quantities of ferric oxide were poured into bodies of water, either quiet or disturbed, and of considerable size. That the bodies of water were frequently local in character, and disturbed by currents either due to rivers or winds, is shown by the lack of continuity and the cross-bedded condition. The variations in the strike of the beds, sufficiently large to be followed for any distance, is extreme. For instance, south of Dundee the strike of a shaly sandstone is almost at right angles to the prevailing northeast-southwest strike of the limestone beds, which are the most continuous beds in the region and must be regarded as indicating the dominant strike in the region. Along the outcrop of this sandstone the author has found many fossils of land and swamp reptiles as if they had been drifted to this particular bar or beach by definite currents. Above this layer there is a loose, coarse, almost arkosic sandstone, and above that a mass of coarse conglomerate which I believe to be what Gordon interprets as formed of previously wave-washed and wave-broken fragments of clay. If it has been formed as Gordon thinks, the action must have been very local, for the bed is not traceable for any great distance. (Plate 9, figs. I and 2.)

There is a general suggestion in all the deposits of the Wichita of a prevalent aridity; this comes from the highly oxidized condition of the material, coupled with the lack of any quantity of vegetable remains. The suggestion is borne out by the fact, noticeable throughout the series, of the complete absence of any sulphides or other unoxidized or uncarbonated minerals. The suggestion of local swamp or lagoon conditions given by the presence of small quantities of blue or green clays and shales is more than counterbalanced by the great preponderance of compounds high in oxygen, by the absence of any black shales, and by the absence of any plant remains other than a few impressions in the sandstones and clays. Moreover, I have submitted some samples of the sand from these beds to Professor Sherzer, of the Ypsilanti Normal College, who assures me that the grains have the appearance presented by wind-blown sands. The frequent presence of copper carbonate may point in a slightly different direction. Copper carbonate, as azurite or malachite, frequently occurs in the form of nodules, or as coatings upon fragments of petrified wood. It seems probable that the copper in the waters (in what form we do not know) was reduced to the metallic state by organic matter, and subsequently oxidized or carbonated. Thin veins of 
metallic copper have been found in the clays near Enid, Oklahoma. These occurrences, however, may be due to mere incidents in a general history. ${ }^{a}$

EVIDENCE OF CLIMATIC CONDITIONS IN CLEAR FORK TIME.

To the west of the road running south from Dundee, approximately along the east line of Baylor County, the beds above the Wichita show a decided change in character. There is a much larger proportion of blue and gray clays, the limestones appear, and there is a change in the character of the conglomerates and coarse sandstones. The pebbles of the latter are more quartzitic, or contain a larger proportion of fragments of igneous rocks. Aside from the limestones, the beds retain the discontinuous character and the pronounced cross-bedding.

The lowest limestone is impure, earthy, whitish on fresh fracture, but weathering to a rusty brown on exposure. It is not over 6 to 8 inches in thickness, and breaks up into small blocks which, because of its superior resistance to the soft clays above and below, determine the presence of a shelf or broad terrace on the south side of the Godlin Creek, south of Fulda and Maybelle, which may be traced even to the Big Wichita, where the blocks are larger. This limestone, with marine fossils, clearly indicates the extension of the sea over the region, probably an extension of the "Albany" sea from the south. The invasion of this sea, with its fauna of marine invertebrates, Myalina, Naticopsis, Nautilus, etc., was preceded by the deposition of 6 to 8 feet of a light blue or white sandy clay, with a considerable calcareous content, which is sharply defined from the red clay below and the limestone above. The layer is fairly persistent, and is found just below the limestone wherever the latter occurs. The white clays do not weather brown upon exposure, indicating a very small content of iron, if any. This means one of two things: either the clays were deposited under conditions which permitted a thorough leaching out of the iron, or they were derived from a region in which there were no iron-bearing minerals. The latter possibility seems the least plausible. In the first place, the origin of the sediments must have been at a considerable distance - the Wichita Mountains to the north or the precursors of the Rockies to the west. And certainly the character of the rocks of the central igneous cores of these masses did not fluctuate. It is far more probable that the sea of "Albany" time, advancing toward the north and west over the semiarid coast, did not reach to the mountains, but did go far enough to produce a decided effect upon the humidity, and so induced a heavier rainfall, and, consequently, a heavier growth of vegetation. Plant remains have not been discovered at any point very far east of the first outcrop of the limestones. ${ }^{b}$ The vertical movement

- Clirk, Ditit of Geochemistry, 2l ed., p. 627; Haworth and Bennett, Bull. Geological Socicty Amer., vol. 12, 1900, p. 2; Schmitz, Trans. Amer. Institute Mining Engineers, vol. 26, 1896, p. 1or. (Impregnations of copper in fossil woxl in the Texis Perminn.)

b See David White, The (haracter of the Fossil Plant Gigantopleris Schenk, and its Occurrence in North America, Proc. U. S. Nit. Mus., vol. 4I, 1912. 
of the sea-level, or the land-level, need have been only very slight to have produced a widespread transgression, and a reverse motion, equally slight, would have excluded the waters. That the effect upon the climate was equally short lived is indicated by the fact that, while the underlying clays are devoid of iron, the limestone above is spotted by ferric oxide and weathers to a rusty brown.

The condition of the limestone is rather puzzling. From general considerations it is supposed that the area of northern Texas, at least as far west as the center of the Staked Plains, was a broad, flat area of aggradation crossed by large streams, a delta of the large size postulated by Barrell in his discussion of the Paleozoic deposits of the Mississippi Valley, and that this was normally more or less arid, its deposits freely exposed to the oxidizing action of the air, and devoid of much vegetation. The advance of the "Albany" sea inducing a greater humidity and plant growth on the land ahead of it and a consequent increase in available $\mathrm{CO}_{2}$ would have resulted in the deoxidization and leaching out of the iron, resulting in the deposition of the light-colored sandy clays. The further advance of the sea would have continued the humid conditions, and we would find the light-colored clays farther to the west and north, and the limestones which replaced them would be free from ferric iron. Either of two explanations may be offered for the presence of the ferric iron in the limestone: (I) The iron, leached from the clays, leaving them white, may have been carried out to where limestone was forming and there deposited as ferric iron; (2) the sea, whose western limits we do not know, may have extended so far toward the land-masses of igneous rocks that there was little of the coastal plain left, and there was no place for the iron derived from the rocks to be deposited and then leached out again before reaching the sea.

The first of these explanations seems the more probable of the two. From all indications, the land, either to the north or the west of where the alternations of white clay and limestone appear, was so remote that it is improbable that the limestone forming sea could have approached near to them, and if, as supposed, there was an increase in the humidity due to the encroaching sea, the degradation of the rocks would not have resulted in the formation of ferric oxide, for Russell has shown that this would occur only when there is a considerable annual period of drought or relative dryness in the region subject to degradation. On the other hand, the white clays probably gave up their original ferric iron as the carbonate, under the action of the $\mathrm{CO}_{2}$ derived from the increased vegetation, and would be redeposited as hematite in the limestone forming in a body of shallow water where there was an abundance of oxygen. ${ }^{2}$

A third hypothesis might be considered: that the white clays were originally deposited as red clays with a considerable content of ferric iron, and that the ferric iron was leached out at a much later period by the action of per-

- Van Hise, Principles of Metamorphism, Monograph 47, U. S. Geological Survey, p. 844. 
colating waters charged with $\mathrm{CO}_{2}$. That some such action has frequently taken place in the Red Beds of Permian and Triassic age is very probable, for the masses of red clay and shale are frequently streaked with green along the line of larger or smaller cracks and as frequently mottled with green spots where slowly moving waters may have encountered some slight excess of carbonaceous material and so reduced the iron. In such cases, however, the mottling and streaking are very pronounced and the action is easily recognized. No trace of it can be seen in the white clay under discussion, which is entirely free from any trace of ferric iron.

That each advance of the sea was short lived is shown by the thinness of the limestones, and that the increase in humidity was due entirely to the presence of the sea is shown by the fact that the deposits immediately above the limestone layers are nonmarine red clays and shales.

Though the conditions outlined are typically shown on the south side of Godlin Creek, they may also be observed in other places, to the north along Hackberry Creek and in the breaks of the Big Wichita, i.e., wherever the Beaverburk limestone shows. The same sequence is repeated several times. In one place the clays below the limestone (the limestone in this exact locality having been removed by erosion) are filled with plant remains, Estheria, some remains of insects, and bones of small vertebrates.

It is notable that the red clays which lie between the layers of limestone and the layer directly above the highest limestone are filled with hard concretions of impure, nodular calcite, endless in variety of form and composition, and the calcite has associated with it sand, mud, iron ore, etc.

It is safe to assume that between the limestone depositing stages of the Clear Fork were periods of greater aridity, when the sea had withdrawn and concentration of the waters was sufficient to induce a high calciumcarbonate content, but not great enough to cause the deposit of calcium sulphate, or salt, except locally, where restricted pools were evaporated to the point of saturation. That the aridity did not progress to a point prohibitive of life is shown by the frequent occurrence of vertebrate fossils in the concretions. It seems probable to. me that certain of the impure limestone beds were, in part at least, deposited from concentrated waters without the action of organisms, for many of them are devoid of marine fossils, and in certain layers east of the Seymour-Vernon road, near the Big Wichita River, the upper surface is marked by sun-cracks, a condition that could only occur in an exposed and drying mass of mud.

Barrel1 ${ }^{a}$ makes the following remarks about the formation of mud-cracks in limestones:

"Mud cracking in chemical sediments, that is, in limestones, must, however, be distinguished in significance from the cracking in claystones. Limestones are carried in solution and their development requires a comparative absence of sand and clay, the mechanical deposits carried by rivers and by waves. The solutions

a Barrell, Amer. Jour. Sci., vol. 36, p. 438, 1913. 
to have sufficient concentration may come from permanent water bodies, either lakes or seas. The deposit, therefore, comes not from the direction of the land, but from the direction of the sea. The cracking goes on between the extreme levels of high and low water, and the slight shifting of level is not a tidal, but at least a seasonal, phenomenon. Such mud-cracking of limestones is a playa phenomenon, and, especially in certain earlier ages, when the lands were base-leveled and lay awash with the sea, broad areas seem to have been at times marine playas. Marine fossils, often of depauperated facies, occur sometimes in the mud-cracked limestones. The nearest approach in the modern world is found, doubtless, in the Runn of Cutch, an area of I0,000 square miles flooded by the sea for a part of the year, during the period of onshore monsoon winds."

This evident sequence of changes in climate and deposits, together with the change in the vertebrate life found in the beds, seems to me to be sufficient evidence upon which to establish the separation of the Wichita beds from the Clear Fork at just about the line originally drawn by Cummins.

Above the highest limestones, appearing at Seymour and on a line east of north from that town to beyond the Big Wichita River, there is a considerable thickness of red clays, sandstones, and conglomerate, including the Wichita conglomerate. This means a return to the more stable and arid, or semiarid, conditions characteristic of Wichita time. But the change in climate was not a sudden one, for overlying the uppermost limestones there are 25 to 30 feet of gray, blue-green, and purplish clays, most clearly seen in their darker phases in the bluffs, where the Seymour-Vernon road crosses the Big Wichita River. These beds give place horizontally to red clay in places, and are overlain by red clay.

Above the first series of red clays with sandstones and shales, which lies over the highest limestone, is the Wichita conglomerate, a deposit of considerable extent in the valleys of Indian and Coffee Creeks (plate 8, fig. 2) on the north side of the Big Wichita River, and traceable over a much larger area, if, as is probable, it is the same layer which occurs at Haskell, in Haskell County. It is a hard, pebbly conglomerate, 6 inches to a foot in thickness, and varying in color from dark to light, but being through much of its extent a deep purplish-red, varying to a light green color, which is very noticeable. ${ }^{\text {a }}$ The lighter shade, a pale green, is the phase seen persistently southwest of Seymour.

The origin of this conglomerate layer is difficult to conceive, occurring between two highly oxidized layers, but itself low in ferric iron. Relatively thin but very persistent, it presents the appearance of a quickly covered sheet of flood deposited material. The possible assumption of its formation by the compound deltas of flooded rivers is negatived by the thinness and uniform thickness of the deposit.

Above the Wichita conglomerate a heavy mass of sandstones forms the capping layer on the south of the Big Wichita River, but on the north side the same sandstone is covered by a considerable thickness of clay and shaly

\footnotetext{
a Case, Bull. Amer. Mus. Nat. Hist., vol. xxili, p. 662, 1907.
} 
layers. The heavy sandstones are responsible for a change in the topography west of a line approximately marked by the Seymour-Vernon road. At Craddock's ranch, on the south side of the river, the lower hills east of the road give place to sharp buttes and deep, steep-sided valleys. The same topography is found a little farther west on the north side. The heavy sandstones at Craddock's ranch are plainly due to the deposits of a strong stream, or streams, from the west, as the cross-section of the bed of such a stream is clearly shown at one place (plate 8, fig. I). Above this series of sandstones, clays, and shales is a very thin calcareous layer, and in places paper-thin red shales, with some insect tracks. This seems to be the highest traceable layer of the Clear Fork. The sandy, easily eroded layers above form a flat or rolling surface as far west as Sagerton, where the Double Mountain beds appear.

\section{SUMMARY OF CLIMATIC CONDITIONS.}

From the above-assembled evidence it is apparent that the Wichita and Clear Fork beds represent the accumulations of sediment on a wide, flat delta or coastal plain, crossed by numerous streams, dotted by inclosed or partly inclosed pools, subject, especially in Clear Fork time, to oscillations of level slight in themselves, but sufficient on such a flat surface to produce wide migrations of the strand-line. The surface was well exposed to the air, and well above the level of ground-water, except during the infrequent periods of submergence, and there were no great areas of stagnant water.

The climate was semiarid in general, but there were changes of short period, apparently due to repeated incursions of the "Albany" sea, with a quick response in the increased abundance of vegetable growth due to the increased humidity.

The source of the material forming the beds of Texas and Oklahoma which carry the vertebrate fossils was undoubtedly the Wichita Mountains and adjacent elevated masses, and we can not doubt that they were much larger in Permo-Carboniferous time than now.

The blue clays, white clays, and light-colored sandstones associated with the limestones of the Clear Fork are similar to the red deposits in all respects but the content of ferric oxide. The source of the material remained unchanged, and there could have been no diminution in the available iron. There is little evidence (a few beds of conglomerate) of any reworking of the once-deposited material. The iron-free beds, or those with ferrous iron, owe their condition to the removal or the reduction of the ferric iron derived from the original rocks. The only available agent for this action would be the carbon derived from the decay of a considerable amount of vegetable matter. As has been repeatedly shown, carbon thus derived would exhaust the available free oxygen, and even extract oxygen from oxides already formed. The carbon dioxide thus formed would convert the iron into the soluble carbonate, which would easily be leached out of the beds. 
As shown above (p. 45; see also p. I04, below), the greatest number of plant remains, and the greatest abundance of iron-free deposits, and deposits with ferrous rather than ferric iron, occur closely associated with the Clear Fork limestones. The series of limestones and associated light-colored clays are separated by beds of red color, high in ferric oxide. This indicates a decided fluctuation in the climate. The cause of this fluctuation is far from apparent. In lack of a better explanation the variations in climate are tentatively associated with the recurrent invasions of the sea from the south. It is conceived that the dominant condition of the whole area, and a wide surrounding region, was semiaridity, with a somewhat higher degree of humidity on the highlands of the ancient Wichita Mountains. When the seas spread in wide and shallow bodies over the flat land and reached far toward the mountains, the waters of the lagoons, estuaries, and pools upon the borders of the advancing sea were warmed, and a large quantity of watervapor rose in the air, but the relative humidity was not increased, since the amount of water-vapor which may pass into the air with a rising temperature is always greater than the amount actually evaporated. If, for some reasoncyclonic or monsoonic effects, for instance-this air with its really large content of water-vapor was drawn across the high land of the neighboring

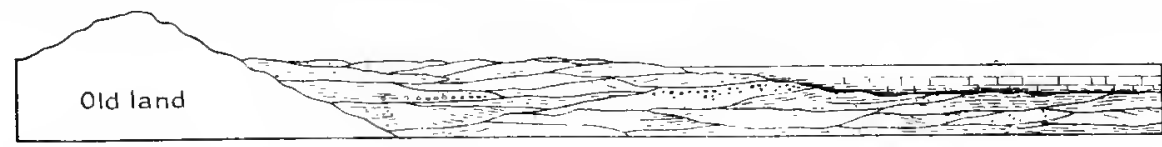

Frg. 8.-Diagram illustrating advance of the "Albany" sea over Wichita and Clear Fork deposits, showing how the presence of the water precedes the deposits and possibly
affected precipitation on land from which deposits were derived.

Wichita Mountains, the cooling of the air would cause an abundant precipitation on the slopes. This water would pass out upon the flats adjacent to the ocean border, increasing the volume of the streams, raising the watertable, and inducing a much greater plant growth. The decay of this vegetation would furnish the carbon necessary to reduce the ferric oxide present, or would exhaust the free oxygen, which would otherwise result in the formation of ferric oxide. The carbon dioxide formed would leach out the iron already deposited, and white or gray iron-free beds would result, or beds with ferrous iron, green, blue, or purple.

These conditions would exist in front of the advancing sea, and the ironfree clays would be below the limestones, as they always are. When the reverse change occurred, following the retreat of the sea, the local evaporation would decrease, the supply of moisture decrease, the vegetation fail, and red-colored rocks would again predominate.

If, as conceived, the oscillations of level were due to tilting, with the axis of tilting south of the Wichita Mountains, the depression of the plain would be accompanied by an elevation of the mountains, accentuating the conditions described; but this movement was never very great in either direction. 


\section{STRATIGRAPHY OF THE RED BEDS IN OKLAHOMA.}

North of the breaks of the Big Wichita the surface of the country is rolling and grass-covered, and there is very little exposure of the rocks or clays, but it is evident that the same formations exposed farther south are continued. Cummins found Wichita fossils (Cricotus, Edaphosaurus, and Dimetrodon) near where the road leading from old Fort Augur to Fort Sill crosses Deep Red River. This is his Indian Territory locality. The author found fragments of Edaphosaurus spines near Emerson and fragments of Eryops and Dimetrodon near Randlett, on the south side of Deep Red Run or River. This last locality is several miles east of where Cummins got his fossils. The surface of the breaks at the last locality shows mostly a deep-red clay, with irregular patches of conglomerate (carrying the bones) and irregular sandstone lenses, with much coarse concretionary material. The top layer is 2 to 3 feet of shaly white sandstone. Both the fossils and the character of the beds would tend to confirm Cummins's conclusion that these beds are of Wichita age. Williston, traversing the same region somewhat farther north, found a few fragments of bones (Diplocaulus, etc.) in isolated patches.

These localities are well within the area marked by Gould " as "red beds of uncertain relationship," surrounding the Wichita Mountains, and we may be certain that the Wichita and Clear Fork extend at least as far north as the fossils have been found, and probably include most of the area marked as uncertain on Gould's map. Immediately surrounding the mountains the land is more rolling and unbroken, and exposures are scarce. The exact age of the sediments near the mountains remains undemonstrated, but Gould describes them in terms that might well be applied to the Wichita or Clear Fork formation in Texas: ${ }^{\mathrm{b}}$

"Lawton Area.-One of the areas referred to includes the country surrounding the Wichita Mountains on all sides, occupying practically all of Comanche and Kiowa Counties, besides eastern Greer, southern Washita, and southwestern Caddo Counties. The deposits of the Greer formation surround the Wichita Mountains at a distance of from 20 to 30 miles, on all sides except on the south. It is between these Greer outcrops and the mountains that the rocks referred to occur. They consist chiefly of red clay shales, with a few ledges of sandstone and dolomite, and in that regard correspond to the Woodward. Like the Woodward, also, these beds appear to underlie the Greer. Until the correlation of the rocks with the Texas beds south of the Red River has been worked out, however, the exact relation of the red beds of this area must remain a matter of doubt."

Between the beds surrounding the mountains, which are so evidently of Clear Fork and Wichita age, and the Enid of Oklahoma, which carries the same fossils, the Greer and the Woodward are exposed in a long strip running northwest-southeast. The Greer has been correlated with the Double Mountain formation, and the Woodward with the upper part of

a Gould, Map, U. S. Geological Survey, Water Supply and Irrigation Paper No. I 48.

b Gould, Ibid., p. 73 . 
the Clear Fork, ${ }^{a}$ but no vertebrate fossils have been found in either one. Unfortunately we have no record of just what becomes of the Greer and the Woodward to the southeast. Gould's map ceases before the end of the formations is reached. But we know that the Wreford limestone has been traced south to the western side of the Arbuckle Mountains as the Payne sandstone, ${ }^{b}$ and that the Cisco begins in Texas just east of Henrietta, and that both of these shade into red beds on the west. The question rises whether the Enid is to be regarded as a continuation of the Wichita and Clear Fork as represented by the Red Beds around the Wichita Mountains, or whether it is possible that the 800 feet, ${ }^{c}$ more or less, of the Greer and Woodward, is to be regarded as completely dividing the two formations, instead of extending over them as an embayment from the northwest. Fossils from the Enid have not been found south of Mulhall, in Logan County, and this leaves quite a distance between the areas whose age has been determined, but, as shown below (see table, p. 96), the vertebrate fossils from Orlando, Pond Creek, and McCann's Quarry are very similar to, or identical with, those from the Texas localities.

Descriptions of the Enid and Woodward have been given by Gould, ${ }^{d}$ and are as follows:

"The Enid formation includes all the rocks of the Red Beds from the base of the Permian to the lowermost of the gypsum ledges on the eastern slope of the gypsum hills. The top of this formation, however, is not a plane, since the gypsum beds, which mark its uppermost limits, are found to be more or less lenticular when traced for long distances. The Enid comprises all of the Harper, Salt Plain, and Cedar Hills members, and the greater part of the Flowerpot member of Cragin's first paper, and the Kingfisher and Glass Mountain formations of his second paper. It is named from the county-seat of Garfield County.

"The Enid outcrops over a larger area than any other formation of the Permian in the Oklahoma, and is exposed extensively in adjoining States. In Kansas it outcrops over parts of Sumner, Kingman, Reno, Barber, and Comanche Counties, and all of Harper County. In Oklahoma it is found in the western parts of Kay, Noble, Payne, Logan, Oklahoma, and Cleveland, parts of Woods, Woodward, Blaine, and Canadian, and all of Kingfisher, Garfield, and Grant Counties. It also extends into the Chickasaw Nation.

"The Enid formation consists chiefly of brick-red clay shales, with some interbedded ledges of red and whitish sandstone. It occurs in two general areas, which may be distinguished on lithological grounds as follows: An eastern area, in which there are a few inconspicuous ledges of sandstone, and a western area, in which the sandstones are mostly wanting. In the present state of knowledge, it is impossible to draw an accurate line of separation between these two areas, and for this reason the strata in them are not defined as separate members.

a Schuchert, Paleogeography of North America, p. 558; Gould, U. S. Geological Survey, Water Supply and Irrigation Paper No. 155, p. I 7 .

b Kirk, Third Biennial Report State Geologist Oklahoma, I904; Gould, Ohern, and Hutchinson, State University Oklahoma Rescarch Bull. No. 3, map.

- Gould, U. S. Geological Survey, Water Supply and Irrigation Paper No. I48, p. 4 o.

d Gould, Ibid., pp. 39-52. 
"The eastern area of the Enid formation is triangular, and occupies several counties in the central part of the Territory, in which there is little hard rock of any kind. Its eastern boundary is approximately along a line from Blackwell to Norman, and its western limit is along a line from Alva to El Reno. It includes eastern Blaine, Canadian, and Woods Counties, all of Grant, Garfield, and Kingfisher, and the western parts of Kay, Logan, Noble, Oklahoma, and Cleveland Counties.

"Throughout this area the soil is red, except where later deposits cover the uplands, or among the sandhills north of some of the streams. Red clays and occasional ledges of thin sandstone outcrop along the bluffs of a few streams. These sandstone ledges, however, are of comparatively little economic value, being generally too soft for building purposes. Quarries occur near Nardin, Kingfisher, Hennessey, and Luella. In the general absence of building stone, foundations for houses are usually made of brick, and artificial stone may come into use extensively.

"The rocks of the western area of the Enid consist chiefly of red clay shale, some inconspicuous ledges of soft sandstone, and occasional bands of whitish or greenish shales, which vary from one inch to several feet in thickness. The upper strata are in places highly gypsiferous, and at some localities brine springs issue from them. No attempt is made to separate the eastern and western areas of the Enid formation, except to state that they are sometimes separable locally a few miles east of the base of the Gypsum Hills.

"The Enid formation is in most places strongly impregnated with mineral salts, particularly common salt and gypsum. In many localities the water from the wells is unfit for drinking, and the people are obliged to use cistern water.

"In the western area, along the base of the Gypsum Hills, salt measures are prominent. The Little Salt Plain, in northern Woodward County, near the Kansas Line, and Big Salt Plain, in the northeastern part of the same county, are both located in the Cimarron Channel, while the Salt Creek Plain, in north-central Blaine County, is on a tributary of the same river. At the Salt Creek Plain some of the most typical saline springs in the Territory may be seen. In several canyons at the head of Salt Creek are exposures of a grayish-red, mottled, saliferous sandstone. This sandstone is often distinctly cross-bedded, and appears to have been tilted; from it issue numerous springs of strong brine. So far as is known, this sandstone is not found elsewhere in the region, and it seems to be a local phase of the clay-shale formation. It is possible, however, that these sandstones are not themselves salt-bearing, but are merely porous strata through which brines from some deep-seated source reach the surface. The water from the springs issuing from the various canyons forms rills, which, in turn, unite to form the headwaters of Salt Creek.

"Above the level of the Salt Plains, and below the gypsum ledges, there intervene I 50 or 200 feet of red clay shale, which is interspersed with bands of whitish, greenish, and bluish clay, and local thin ledges of gypsum.

"The very soft material of which this shale is composed renders it particularly susceptible to the action of the weathering, and the entire thickness is characterized by marked erosion forms. Wherever the cap of gypsum has been removed over any considerable area, or for any great length of time, these shales have been worn away. Perhaps the most common erosion form is that of cones of red clay cut by deep and uneven gullies - regular bad lands structure. Not infrequently rows of these cones are arranged palisade-like along the summit of a fast-disappearing ridge, into which gullies are eating their way. In the Glass Mountains, for instance, the slope of the bluffs below the gypsum ledges is much cut by erosion. The action of the water has produced a great variety of unusual forms. Small buttes and but- 
tresses, cones and minarets, pinnacles and peaks, shoulders and ridges, domes, towers, chimneys, gullies, ravines, and all sorts of fantastic shapes have been carved by erosion from the blood-red shales along the slope of the bluffs.

"The face of the bluffs is frequently covered with fragments of gypsum, either in the form of plates of transparent selenite or in the form of concretionary masses. The selenite is usually found in seams running diagonally through the clay, and the crystals weather out and reflect the sun from thousands of points, making the slopes appear to be covered with glass, whence the name, Glass Mountains.

"The thickness of the Enid formation is unknown, but it is probably not less than I,200 feet, and may reach I,500 feet. The well at Fort Reno was started at about the same level as the top of this formation and reached a depth of 1,370 feet, the drill stopping in red clay. It is possible, however, that this well passed through the Permian rocks into beds of Pennsylvanian age beneath. At Spencer, I 2 miles east of Oklahoma City, a well passed out of the Red Beds at a depth of 1,550 feet. The greater part of this thickness, however, was in Pennsylvanian rocks.

"Iloodward Formation.-Above the Blaine are approximately 300 feet of rocks, consisting chiefly of shales, sandstones, and dolomites, and distinguished from the formations above and below by the prominence of dolomites and the absence of gypsum. The formation includes all the rocks between the two conspicuous gypsum horizons, the Blaine and the Greer, and in general it may be divided into three members-the Dog Creek, the Whitehorse, and the Day Creek-which were all recognized and named by Professor Cragin from localities in Kansas, except that his term Red Bluff was preoccupied, and for it the name Whitehorse has been substituted. For the formation as a whole, from the top of the Shimer gypsum to the base of the Chaney gypsum, the name Woodward is proposed, from the county in Oklahoma, where the strata are well represented.

"Dog Creek Shales Member.-The Dog Creek member is composed mainly of clays, containing occasional thin ledges of magnesian limestone, which in places grade into a fair quality of dolomite.

"The ledges, however, are usually thin and rarely sufficiently conspicuous to be worthy of more than a passing notice. Professor Cragin's original description of this member is as follows:

"The Dog Creek *** consists of some 3 o feet, or locally of a less or greater thickness, of dull red argillaceous shales, with laminæe in the basal part and one or two ledges of unevenly lithified dolomite in the upper. The color of these shales resembles that which prevails in most of the divisions below rather than of the terranes above Dog Creek."

"In his second paper he modifies his description in this way:

"In central Oklahoma it is a great dolomite formation, laminated dolomite occupying a considerable part of the thickness."

"In his second paper he suggests that the name Dog Creek be changed to Stony Hills. The writer agrees that the name Dog Creek is, perhaps, not the best that could be used, but in view of the fact that the dolomites which make up the Stony Hills in eastern Blaine County belong to the Blaine formation, and do not belong to the Dog Creek, there seems to be no good reason for using the name Stony Hills to designate this member.

"Studies made during the last 3 years have demonstrated that in many parts of Oklahoma the thickness of the Dog Creek is much greater than that given by Professor Cragin. Near Quinlan, in eastern Woodward County, the aneroid readings indicate 225 feet as the thickness of these beds, measured from the top of the underlying gypsums of the Blaine formation to the sandstones of the next higher 
formation of this member, the Whitehorse, and in a number of localities I 50 and I 75 feet were recorded. Exposures are common along the top of the Gypsum Hills from Canadian County to the Kansas line and beyond.

"Whitehorse Sandstone Member.-The Whitehorse sandstone was also described (under the name of Red Bluff sandstone) by Professor Cragin, in his first paper, as follows:

"This formation consists of some I 75 or 200 feet of light red sandstones and shales. $* * *$ Viewed as a whole it is very irregularly stratified, being in some cases considerably inclined, in others curved, and this oblique and irregular bedding, being on a much larger scale than that of the ordinary cross-beddings, at first glance gives the impression of dips, anticlines, synclines, etc., that have been produced by lateral pressure; the dips, however, being in various direetions. $* * *$ The Red Bluff Beds exhibit the most intense coloration of any of the rocks of the series. When the outerops are wet with recent rains their vividness of color is still greater, and the contrasts of their almost vermilion redness with other colors of the landscape are most striking. Spots and streaks of bluish or greenish gray sometimes occur in these rocks, but not to nearly so great an extent as in the lower beds. The sandstones of the Red Bluffs are generally too friable for building stone, but in some instances selected portions have proved hard enough for sueh use, and are fairly durable."

"In Oklahoma the Whitehorse member often weathers into conspicuous buttes and mesas. For instance, in eastern Woodward and western Woods Counties a row of these buttes, which rise Ioo to 200 feet above the surrounding country, extends from the vicinity of Whitehorse Springs, whence the name, southwest across the Cimarron, to the high divides beyond. To some of these buttes characteristic names have been given, as Lone Butte, Potato Hill, Watersign Hill, Wild Cat Butte, and the like. The noted Red Hill between Watonga and Geary, in southern Blaine County, is composed chiefly of the Whitehorse formation. South of South Canadian River this sandstone thickens, and on weathering often forms conspicuous bluffs, such as the famous Caddo County Buttes, southwest of Bridgeport. The Whitehorse sandstone is exposed along the Washita from near Chikasha, Indian Territory, westward, and in the vicinity of Anadarko it forms bold bluffs both north and south of the river, and extends as far west as Mountain View. Ledges which probably belong to the same general horizon outcrop north of the Wichita Mountains in the vicinity of Hobart and Harrison, and it is not impossible that further studies may demonstrate that the same beds extend under the upper gypsums across Greer County.

"Day Creek Dolomite.-Resting upon the upper part of the Whitehorse sandstone in Kansas and Oklahoma is a conspicuous ledge of hard white dolomite, first described by Professor Cragin from exposures in southern Kansas, as follows:

"Upon the latest of the Red Bluff rests a persistent stratum of dolomite, varying in thickness from less than a foot to 5 feet or more. $* * *$ It is a true dolomite, containing with the carbonate of lime an equal or even greater pereentage of carbonate of magnesia. *** Though not of great thickness, it is an important member of the upper Permian of southern Kansas and northern Oklahoma, owing to its persistence, which makes it a convenient horizon of reference. ${ }^{*} * *$ The stone is nearly white in fresh fracture, weathering gray, and often has streaked and gnarly grain resembling that of fossil wood. * * * Its cherty hardness and fracture are not due to the presence of silica, as one is tempted to infer, but are characters belonging to it as a dolomite. It is a durable building stone."

"In his second paper on the Permian rocks, in describing a typical Oklahoma locality, Professor Cragin says:

"The brow of the Red Hills near Watonga, Oklahoma, is capped with the Day Creek dolomite, which here presents itself a compact stratum of gray, somewhat pinkish or reddish tinged, cherty, hard rock, little different from the typical ledge that skirts the flanks of Mount Lookout, in Clark County, Kansas. The stratum here has a thickness of 3 feet." 
"The line of outcrop of the Day Creek in Oklahoma is not continuous. Nevertheless it is found in numerous localities, and on account of its distinctive lithological appearance it is always easily recognizable. It is displayed on many of the hills of Woodward County, not only north of the Cimarron, but also between the Cimarron and the North Canadian, and south of the latter stream. In Blaine County it forms the caps of a number of the prominent hills, notably the Red Hills between Geery and Watonga. South of the South Canadian River, in Caddo County, the dolomite covers the Whitehorse Buttes southwest of Bridgeport, and outcrops southwestward as far as the headwaters of Cobb Creek and on the west side of the creek past Colony. In the vicinity of Mountain View, in the valley of Washita River, a ledge of dolomite appears at the same general level as that occupied by Day Creek, and another dolomite ledge in the hills north of Harrison may provisionally be referred to this horizon."

In a recent paper Beede ${ }^{a}$ states as to the eastern outcrop of the Neva limestone in Oklahoma which he regards as marking the Permian horizon:

"So far as the evidence has been worked out it seems necessary to place the base of the lower Permian either at the base of the Elmdale formation, or, at the highest, at the top of the Neva limestone." (p. 2 I.)

This is somewhat lower than the Cottonwood limestone which has been rather generally regarded as marking the lower line of the Permian. Beede's selection of this bed as marking the line between the Pennsylvanian and the Permian is based upon the faunal changes shown by the invertebrates. A detailed discussion of the stratigraphy and sections shown along the outcrop of the Neva limestone forms the first part of the paper. The accompanying map shows the outcrop of the limestone, mark-

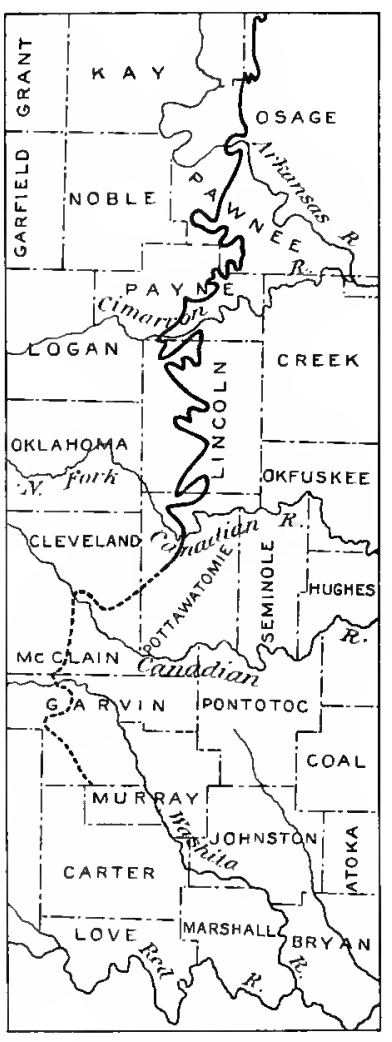

FIG. 9.-Map of a portion of central Oklahoma from Kansas to Texas showing the approximate eastern limit of Permian rocks. (After Beede.) ing, according to Beede, the eastern limit of the Permian in Oklahoma.

\section{STRATIGRAPHY OF THE RED BEDS IN KANSAS.}

Beyond the Oklahoma line, vertebrate remains have been found only in Cowley County, Kansas, where, about 5 miles northeast of Maple City, a few bones were discovered in the excavation of a well, and forwarded by Professor Gould to Dr. Williston, who determined them as Permo-Carboniferous in age. ${ }^{\mathrm{b}}$ Adams provisionally identifies the horizon of these bones as the Garrison. ${ }^{c}$

a Becde, Oklahoma Geological Survey, Bulletin 121, 1914. (The Neva Limestone in northern Oklahoma, with remarks upon the correlation of the vertebrate fossil beds of the State. Eastern outcrop of the Permian red beds in Oklahoma, with a discussion of the lithologic and color changes.)

b Williston, Kansas University Quart., vol. vi, No. I, p. 53.

c Adams, Bull. U. S. Gcological Survey No. 2 I I, p. 72, I903. 
"Near the southern border of Kansas, in Cowley County, at a place about 5 miles northeast of Maple City, some vertebrate remains were found in the shale thrown out in digging a well. These were collected by Mr. C. N. Gould, and sent to Dr. Williston, who identified the bones generically, and considered them as indicating the Permian. The horizon in which these bones were found has been identified as the Garrison formation, although the correlation rests necessarily upon rather meager evidence, since the distance from the type locality is considerable and the invertebrate fossils have not been studied critically enough to admit of accurate identification of horizons.

"In northeastern Oklahoma, in the area of the so-called Red Beds, there is a locality which has yielded Permian vertebrate remains. The material has come from two places: one known as McCann's Quarry, 5 miles southeast of Nardin, in Kay County, the other 2 miles northeast of Orlando. The material has been studied by Dr. Williston, who has found that it represents characteristic Permian forms, such as have been reported from Texas. The stratigraphic position of the vertebrates from near Nardin and Orlando has not been definitely determined. They occur to the southwest of the southern extension of the so-called Permian limestones of the Kansas section, but no horizon has been traced connecting the locality with the Kansas section.

"The identification of the Permian in the western interior of the United States for a long time rested upon the occurrence of reptilian remains, such as were first described by Cope from the Red Beds of Texas. The occurrence in Kansas and Oklahoma of the same genera which are found in Texas makes it possible to correlate the formations tentatively. The material in the Kansas section is meager. No doubt more will be found, and possibly Permian forms occur, at lower horizons than the Garrison formation."

The Garrison lies below the Wreford, and is given by Adams as I 4 o feet thick.

There is, in the possible relation of the Red Beds around the Wichita Mountains to those of the Enid formation, the suggestion that the gradual change of the limestones into red shales and sandstones began at a lower level in the north (Kansas and Oklahoma) than it did in the south (Texas). The fossils from Kansas are perhaps a little closer to those of Illinois than they are to those of Texas, but the number of forms recovered is so small that any conclusion drawn from them is at best very uncertain. The fossils from Oklahoma are very close to those of Texas, and do not in themselves warrant the suggestion that the beds are lower.

If we examine the map of the Permian in Schuchert's Paleogeography of North America, and also Ulrich's table of submergences, ${ }^{a}$ we note the persistence of a trough from the Gulf of Mexico which extended northwest around Ozarkia, and over a portion of the Ouachita uplift. It is probable that the limestones on the eastern side of the Red Beds were deposited in this extension of the sea, and that the red sediments came from the west and the southwest. It is practically certain that this gulf was fairly narrow, and there may have been red beds on the east derived from the land in southwestern Missouri, but if such beds existed all traces of them have been removed by erosion.

While most of the animals of the Texas region must be supposed to have inhabited the uplands and shores of the western and southern localities, it is alto-

a Ulrich, Bull. Geol. Soc. Amer., vol. 22, No. 3, pp. 346, 347. 
gether possible that they originated in migrations from the east around the northern side of Ozarkia, and that they may have reached the regions in Kansas earlier than they did the more southern regions, for we know that there was a gradual and progressive elimination of the waters on the surface of the continent from the east toward the west during the Pennsylvanian and the Permo-Carboniferous.

\section{EXTENSION OF THE RED BEDS TO THE WEST BEYOND THE LIMITS OF VERTEBRATE FOSSILS IN THE TEXAS PROVINCE.}

Cummins, in his maps of the Permian of Texas, has drawn the limits reaching far to the south of the bone-bearing beds, as noted above (p. 6), and west to the Staked Plains. Beede ${ }^{a}$ has maintained that the Red Beds on the east side of the Pecos Valley are equivalent to, or are a continuation of, the upper beds of PermoCarboniferous age of Texas and Oklahoma, and this is in confirmation of Cummins's earlier statements.

He shows that Guadalupian limestones shade north and east into red beds which are the same as those to the east, and argues that the conditions indicated by these beds isolated the invertebrate fauna of the Pecos Valley region from that shown in the Whitehorse formation in Oklahoma and the eastern part of the Panhandle of Texas.

"If the conclusions reached above are correct ${ }^{\mathrm{b}}$ it leads at once to the correlation of the Kansas and Guadalupian sections. If we use the Whitehorse sandstone, probably the equivalent of the beds in contact with the Guadalupian limestone near Carlsbad, as a common basis of correlation of the two sections, we attain the result shown in the accompanying diagram [fig. Io]. Disregarding their actual fatual relationships and comparing them as to their thickness, the strata of the two sections compare as follows, the figures of the Guadalupian rocks being approximations:

"In southern New Mexico we have some 4,500 feet of the Guadalupian series, composed of 2,100 feet of

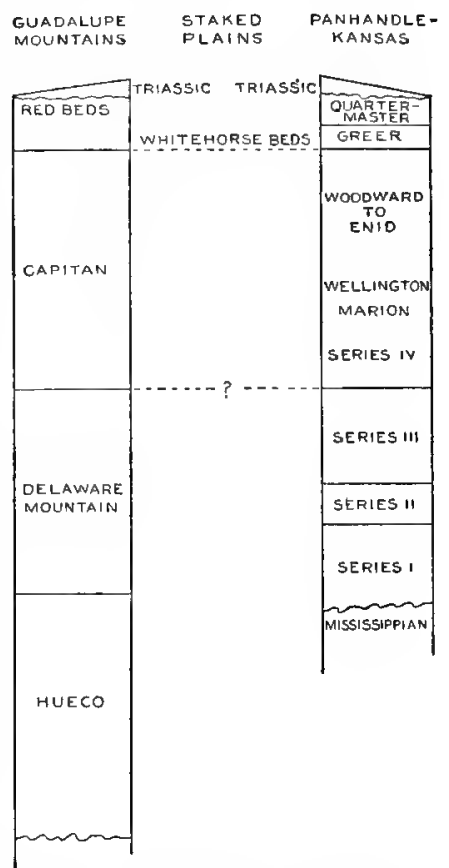

FIG. I0.-Diagram showing relation of beds in Guadaloupe Mountains to those in Texas and Kansas. (After Beede.) Capitan and overlying limestones, and 2,400 feet of the Delaware Mountain formation, composed of limestones and sandstones overlying 5,000 feet of Hueco limestones. Beginning at the same horizon in Kansas, we have the remainder of the Red Beds, the lighter Permian and the Pennsylvanian, aggregating about 4,500 feet of strata, composed of limestone shales and sandstone. So far as mere thickness is concerned, it leaves the base of the Delaware Mountain formation about on the level with the Cherokee shales (as exhibited in Kansas). The horizon of the base of the Delaware Mountain formation in the Kansas section, interpreted upon its fauna, or actual time equivalency, may be a very different matter. The base of the Capitan falls near the bottom of the Elmdale formation stratigraphically, which is

\footnotetext{
"Beede, Amcr. Jour. Sci., vol. xxx, Aug. I9Io, p. I3I.

b Beede, Ibid.
} 
probably not far from its correct faunal correlation as well. The paleontological comparisons are yet to be worked out. The unconformity above the Capitan limestone, and locally even in the Delaware Mountain formation, the Capitan having been carried away, is not taken into account in making these comparisons. ${ }^{\text {a }}$ It is probable that it diminishes rapidly to the northward, where it is of less consequence.

"One of the most interesting features of the Guadalupian fauna is its isolation. As has been stated by Girty, the fauna is a unique one, and, as a unit, is now known from no other part of the western hemisphere. At first thought it seems peculiar

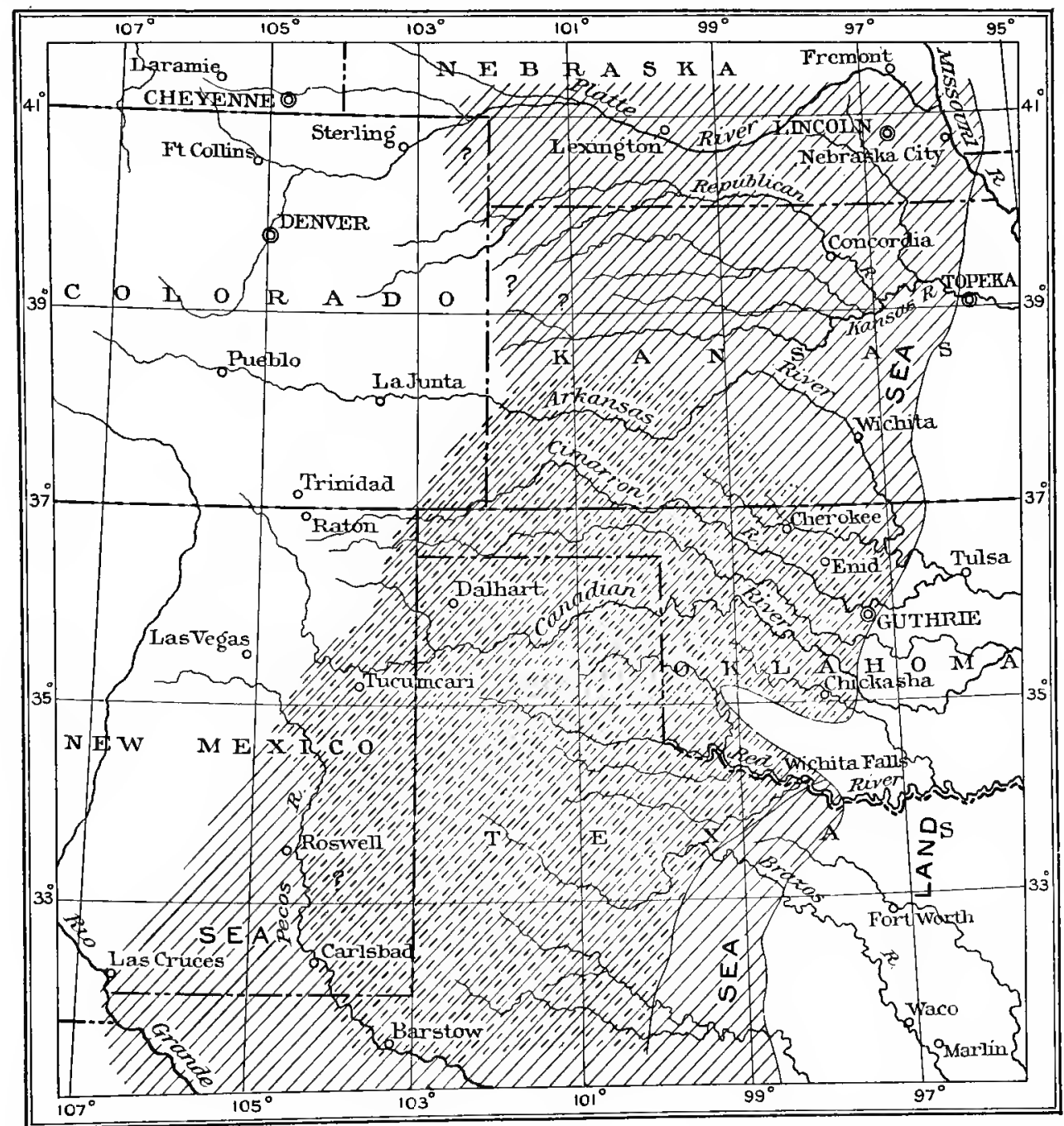

FIG. I I.-Map showing Beede's idea of the Paleogeography of the Red Beds in the southern part of the Plain Province. (After Beede.)

that more of its members were not distributed over the adjacent regions where contemporaneous strata occur. Their absence in such rocks has been a serious difficulty in any attempt to correlate them with other American faunas.

"In the first place, the lower Red Beds lying to the eastward, with which the Guadalupian limestones are probably contemporaneous, are believed by some to be to a considerable extent of subaërial origin, while the temporary seas that occupied portions of it from time to time were too concentrated in salt content for normal

a Richardson, University Mineral Survey Texas, Bull. 9, pp. 43, 44, 1904. 
marine faunas. So far as my collecting in the typical Capitan limestone goes, the fossils were abundant only in the purer limestones, and were very rare, or wanting in what appeared to be the dolomitic portions of it. These limestones occur in the Apache Mountains and at Guadalupe Point, but appear to be wanting, as does the fauna, north of the Texas line; the only exceptions noted were Fusulina elongata and one or two other species in Dog Canyon and Sitting Bull Canyon. From this it will be seen that the fauna was closed off on the north by untoward conditions and on the east by the red bed sedimentation, which constituted a barrier. No other barrier is known.

"Two other considerations must be taken into account. First, that the Permian facies of this fauna may be an abnormally early precursor of the Permian faunas developed in an isolated basin. Such an occurrence of Permian forms is known in Kansas well down in deposits of Pennsylvanian age. However, the variety and richness of the Guadalupian fauna, which possess such a young appearance, seem to me to argue against this hypothesis. Second, the other possibility is that the fauna is no older than it appears, and that it developed normally with little outside connection, as did the Kansas Permian fauna. The same features as before would have controlled its isolation. Much of the Red Beds being almost a land surface a considerable part of the time-if we accept the subaerial origin of a large part of the deposits-aggradation may have but slightly overbalanced degradation, and they may have accumulated slowly for that class of sediments. Thus, though disturbances raised the southern part of the Guadalupe limestones above sea-level, and permitted their partial removal and the subsequent deposition of the upper Red Beds upon the eroded surface, the fauna may well have been an early Permian fauna. Until further data are at hand I am much inclined to this latter hypothesis. The fact that several hundred feet of the Kansas Permian deposits grade off into typical red beds in a very short distance in Oklahoma is suggestive of possible conditions east of the Guadalupes. If such were the case, we would expect the Guadalupian faunas to cease as abruptly upon the strata changing to the Red Beds as the Kansas faunas do upon entering the Oklahoma Red Beds.

"At the same time, owing to the very nature of the origin of the Red Beds, their extreme southwestern part may have been deposited slightly later than the main mass farther to the north and east. However, this is regarded more in the nature of a possibility than a probability.

"The accompanying map [fig. II] indicates the probable relationship of the marine areas during Council Grove-Chase and Guadalupian time in the immediate area under consideration. No attempt is made to show the full extent of deposits laid down at this time. The full lines indicate marine conditions and the lines alternating with stippled ones continental-marine deposition. The extent to which the two factors contributed to the formation of the Red Beds is at present unknown. The area of marine conditions in Central Texas is to represent the Albany sea."

EVIDENCE OF A BARRIER OR INTERRUPTION OF DEPOSITION OF RED BEDS TO THE WEST.

There is some considerable probability in this suggestion, but the author, traversing the region from Tucumcari to Las Vegas, New Mexico, in the summer of 19I2, found no trace of red beds which could be referred to the Permo-Carboniferous. The lowest red beds encountered yielded Phytosaur remains and Unio, clear evidence of their Triassic age. ${ }^{a}$

"Case, Jour. Geol., vol. 22, No. 3, April-May r9I 4 . In the paper cited the author gives details of the stratigraphy of this region (see plates $\mathbf{I} \mathbf{I}-\mathbf{I} 3$ ). 
The Red Beds were followed from their eastern limit in Oklahoma to their final appearance as vertical beds on the eastern side of the Rocky Mountains, and kept continuously in sight, except where they disappeared beneath the Dakota Cretaceous, in the mesa just east of Las Vegas, and under the Tertiary of the Staked Plains. The last trace of the Permo-Carboniferous was seen on the east side of the Staked Plains, near Spurr, in Dickens County (plate I3, fig. I); on the west side all the red beds along the route followed are Triassic (plates II, I2, I3). At Las Vegas Hot Springs the beds are vertical (plate I2, fig. 3), or nearly so, and the conditions are extremely unfavorable for seeking vertebrate fossils, but after a half-day's careful search a single imperfect tooth of a Triassic dinosaur was found in a bed of conglomerate. This tooth was discovered near the middle of the section and demonstrates that the upper half, or more, of the exposure is Triassic. As the beds below are strikingly similar to the one in which the tooth was found, it is apparent that if any Permo-Carboniferous appears on the side of the mountains it is very thin. I am inclined to the belief that the Permo-Carboniferous beds end somewhere beneath the Triassic in eastern New Mexico.

Schuchert, in his paleogeographic map of the Permian, shows the Guadalupian region as distinctly separated from the Texas-Oklahoma-Kansas region. Beede believes in the presence of a barrier to marine life, but assumes the continuance of red-bed deposition. ${ }^{a}$ Schuchert, quoting Girty, asserts the independence of the Hueconian and Guadalupian faunas and later deposits of the Cordilleran sea. ${ }^{\text {b }}$ Girty says:

"Through the west, however, these faunas will probably prove to have extended widely. The Hueco will perhaps prove to be the same as the Aubrey formation of northern Arizona."

Schuchert himself says: ${ }^{c}$

"The writer believes that the Aubrey faunas are younger than those of the Hermosa, but still Pennsylvanian, and of a distinct faunal province-that is, of the western Cordilleran basin."

Schuchert again quotes from Girty: ${ }^{\mathrm{d}}$

"The Mississippian faunas, together with the earlier Pennsylvanian ones, appear to be absent [in the Trans-Pecos region]. The Hueconian fauna is widely distributed over the West, ranging, indeed, into Alaska, while it is even recognizable in Asia and eastern Europe. Most of the occurrences of Carboniferous in the West can be referred to this series, though some of them present more or less distinct facies."

And again:

"The life of the Guadalupian is quite unlike the faunas of eastern North America, and almost equally unlike most of those of the West. The nearest are probably those of the Salt Range and Himalaya, in India, and the Fusulina limestone of Palermo."

These quotations from Schuchert and Girty seem to confirm the author's opinion that the Permo-Carboniferous does not occur on the western side of the Staked Plains, at least in the latitude of Las Vegas, in Texas and eastern New Mexico.

a Beede, Amer. Jour. Sci., vol. xxx, Aug., I9Io, p. I38.

b Schuchert, Paleogeography of North America, p. 573. c Loc. cit., p. 574 .

d Girty, Jour. Geol., I909, p. 3 I I. 


\section{CHAPTER II.}

\section{DESCRIPTION OF THE NORTHERN PORTION OF THE PLAINS PROVINCE AND THE EASTERN EDGE OF THE ROCKY MOUNTAINS.}

(See plates 2 and 3 , opposite pages 64 and 66 .)

Beede $^{a}$ has shown that the limestone which in southern Kansas can be traced into the Red Beds of Oklahoma can be followed north through Kansas and even into Nebraska. Its western extension in these States is covered by Cretaceous and Tertiary deposits. Barbour ${ }^{\mathrm{b}}$ says that the Red Beds are lacking in Nebraska, though the Permian limestone appears in the eastern part. This means that they do not appear on the surface and have not been reported in well records.

Darton, ${ }^{\text {}}$ in his sections across Nebraska, suggests the disappearance of the Red Beds to the west by playing out, but this is only a suggestion.

The age of the Red Beds in Dakota, Wyoming, and Colorado is still uncertain. The upper portion is without doubt Triassic, but there is good reason to believe that the lower parts may be Permo-Carboniferous. In the following pages evidence is given in some detail to show that the PermoCarboniferous portion of these beds may be a part of the area of deposition in which the vertebrate remains occur in Texas, Oklahoma, and Kansas, and that the two regions are connected by red beds continuous with the western edge of the limestones of the same age which can be traced through Kansas, Nebraska, and eastern South Dakota.

Knight, ${ }^{\text {in }}$ I 899, suggested that the so-called Permian beds of Nebraska, Kansas, and Texas (including those of Oklahoma) were all connected originally and that they extended to the Rocky Mountains. In I902 the same writer $^{*}$ referred the Red Beds of the Laramie Plains to the Paleozoic on both stratigraphical and paleontologic evidence and showed that the invertebrate fauna resembles that of the Kansas and Nebraska beds. He says:

"The Red Beds merge into the limestones or rest conformably upon them, and here we have conditions very similar to those that have been recently discussed from southern Kansas and southward. From our present knowledge it seems advisable to refer the Red Beds of the Laramie Plains to the Permian."

He further states that others have mentioned that south of the Union Pacific Railroad the beds rest on the Archean and north of it conformably upon the limestone. He says:

"I have found that the limestones shade almost imperceptibly into the red sandstones, and that the strata of the lower portion of the Red Beds are identical

a Beede, Kansas University Quarterly, vol. Ix, p. I9I, 1900.

b Barbour, Geol. Survey Nebraska, vol. I, p. 129, 1903.

- Darton, U. S. Geological Survey, Professional Paper No. 32, plates X and XI.

'Knight, Jour. Geol., vol. vir, p. 369, 1899.

- Knight, Jour. Geol., vol. x, p. 420, 1902. 
with the strata of the limestones to the northward, the difference in the lithological characteristics being due to the varied physical conditions during sedimentation."

In 1907 , Darton reported finding a fossiliferous limestone I 50 feet below the top of the Red Beds on the west slope of the Bighorn Mountains, 3 miles north of Thermopolis, Wyoming. " The Red Beds are here nearly I, ooo feet thick and lie upon upper Carboniferous limestones and sandstones. This limestone carries a Permo-Carboniferous fauna similar to that which has been found in the basal portions of the Red Beds in adjacent regions. The occurrence of the fauna in the limestone mentioned leaves only I 50 feet to represent the Triassic. In the vicinity of Laramie, Knight found fossils of upper Carboniferous age. It was found that on both sides of the Laramie Mountains the upper Carboniferous limestones and sandstones shade into red beds toward the south. These are the same beds which were called lower Wyoming by Eldridge on the Rocky Mountain front and Fountain by Gilbert and Cross. The Chugwater Red Beds which overlie the upper Carboniferous to the north continue unchanged on the Rocky Mountain front and overlie the lower Wyoming and the Fountain formations. Williston regarded the beds here called Chugwater as Triassic, from the evidence of vertebrate fossils, ${ }^{\mathrm{b}}$ but the invertebrate fauna is apparently Permo-Carboniferous.

In I909, Darton ${ }^{c}$ wrote:

“The Pennsylvanian division, which consists mainly of shales and sandstones in northern Wyoming, contains thick bodies of limestone, but on both sides of the Laramie Mountains, south of the latitude of Laramie, this mostly gives place to sandstone, largely of a red color."

In the same paper he stated that "in the eastern Front Range in Wyoming limestone predominates in the Casper formation to the north, but much reddish sandstone is included; farther south and in Colorado the formation changes to red sandstones, constituting the 'lower red beds' or Fountain formation" (plate 19, figs. I and 2). And again: ${ }^{d}$

"Fossils found at various horizons in limestones in the Chugwater Red Beds do not afford conclusive evidence as to age. Those in the lower limestones in the Bighorn Mountains and other uplifts are believed to be 'Permian' in the sense in which the term is used in the Mississippi Valley. Many fossils occur in the limestone 150 feet below the top of the formation, on the east bank of Bighorn River, 3 miles below Thermopolis. According to Dr. G. H. Girty, the principal species is Natica lelia, usually considered diagnostic of the Triassic, but probably it is older. Bakewellia and probably Pleurophorus may also be present, and an Aviculipecten occurs resembling $A$. curticardinalis, which is characteristic of the Permo-Carboniferous of Utah. Dr. Girty is inclined to correlate the fauna with the PermoCarboniferous of the Wasatch Mountain section. The I5o feet of red shales and sandstones which overlie this limestone may possibly represent part of the Tri-

" Darton, Bull. Geol. Soc. Amer., vol. I7, p. 724, 1907.

b Williston, Jour. Geol., vol. 12, I904.

- Darton, Bull. Geol. Soc. Amer., vol. XIX, p. 403, 1909.

d Darton, U. S. Geological Survey, Professional Paper No. 62. 
assic. In the lower portion of the Chugwater formation, to miles southwest of Casper, a cast of Schizodus wheeleri was found. The form is usually regarded as Pennsylvanian."

In the Black Hills the Minnekahta and Opeche are regarded as probably Permian. The Minnekahta is a light pinkish or purplish limestone grading downward into purple, pink, and red shales, which weather with a nodular surface and finally pass rapidly into the deep red, sandy shale of the Opeche formation. The Opeche is assigned to the Permian because red beds occur in the Permian of Kansas and Nebraska as intercalated layers between limestones. The material is a soft red sandstone and a red shale (plates I4 and I5).

In Professional Paper 32, United States Geological Survey, Darton discusses the character of the Red Beds of the Front Range of the Rocky Mountains. The upper Carboniferous limestone is found in the northern part of the Front Range near the Wyoming line, and in the Culebra Range it appears to merge into the Fountain Red Beds, which he believes to be the exact equivalent of the lower Wyoming of Eldridge and the Badito of Hills, and to represent the Amsden formation and overlying Tensleep sandstone of the Bighorn Mountains and the Minnelusa formation of the Black Hills (p. 8o). The lower Red Beds of the Rocky Mountain Front Range have yielded no fossils and undoubtedly merge into limestones both on the north and the south and can be correlated with formations in the Black Hills and the Bighorn Mountains. Darton says further:

"Throughout the Black Hills, the Bighorns and much of the region to the south the upper Carboniferous and Red Bed series presents a general succession as follows, beginning at the top: A thick mass of gypsiferous, red, sandy shales; a thin mass of thin-bedded limestone; a thin mass of red, sandy shales; a thick, hard, lightcolored, fine-grained sandstone; and, at the base, limestones and sandstones giving place to sandstones and conglomerates, the basal series lying unconformably upon the Mississippian limestones, on Cambrian, or on old granites and schist" (p. I 59).

"Near the Colorado-Wyoming State line the upper Carboniferous limestone may be seen to merge into red sandstones, apparently by the expansion of included reddish sandy layers observed northwest of Cheyenne and a corresponding thinning of the limestones. A mass of red sandstones and conglomerates, which lies at the base of the limestones for some distance, is seen also to thicken gradually to the south" (p. I6r).

"The name 'Fountain formation' has been used to comprise all of the red beds in the region northeast of Canyon and southwest of Pueblo, and if, as I believe, the Chugwater (upper Wyoming) formation thins out a short distance south of the Garden of the Gods, the Fountain formation corresponds in the main to the lower Wyoming, and is the product of similar conditions at the same geological epoch. I do not see the slightest reason for supposing that the two formations are not equivalent.

"The character of the beds northwest of Pueblo and in the Garden of the Gods region is precisely the same as in the district west and north of Denver, and although I made special search I could find no evidence of overlaps or unconformities of any kind within the great uniform mass of red grit deposits. 


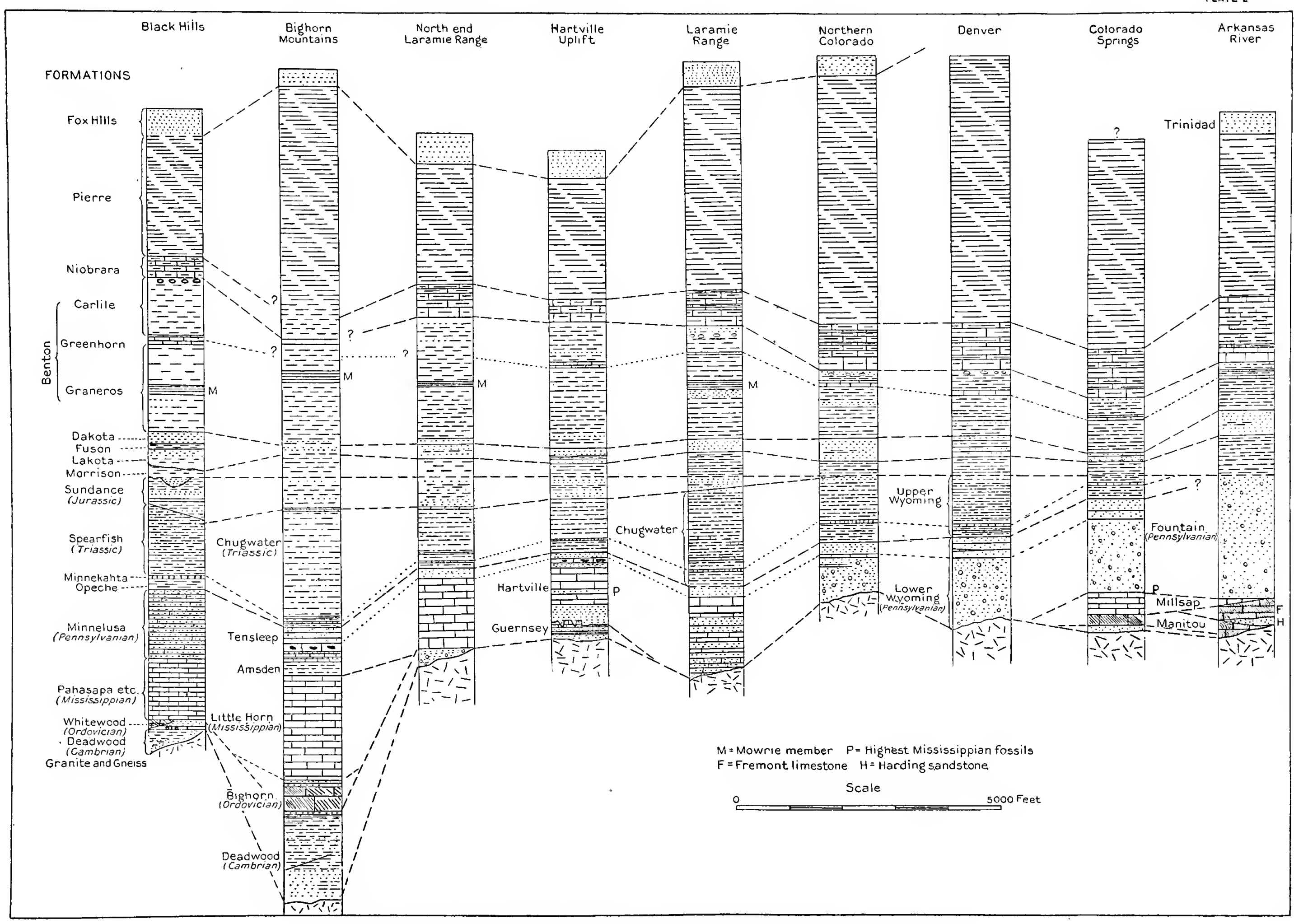

Chart of Columnar Sections of the Black Hills, Bighorn, and Rocky Mountain Front Range. After N. H. Darton. 

"The upper and lower Wyoming are very distinct from each other from the Garden of the Gods north to the State line, as recognized by the geologists of the Hayden survey and clearly set forth in the Denver monograph, where the terms 'lower Wyoming' and 'upper Wyoming' were introduced. The upper Wyoming consists mainly of fine-grained sediments extending from the 'creamy sandstone," which I believe to be the equivalent of the Tensleep, to the base of the Morrison formation. It consists mainly of bright-red shales, always with a thin limestone layer or series toward its base, and from Platte Canyon northward with a massive pinkish sandstone at its top. The included limestone is believed to represent the Minnekahta horizon of the Black Hills and other regions, indicating a short but widespread interval of limestone deposition at this epoch in the West. The few fossils found in this limestone unfortunately do not settle its age, but there appears to be but little doubt that its representative in the Black Hills is Permian. The overlying red shales, with gypsum, in northern Colorado may be Permian or Triassic, for the fossils in the limestones which occur near the top of the extension of this series into the Bighorn uplift do not indicate whether the beds are Paleozoic or Mesozoic.

"The Chugwater formation (upper Wyoming Red Beds) is only r 40 feet thick at the Garden of the Gods and appears to thin out and disappear a few miles south, bringing the Fountain formation into contact with the Morrison, a relation due either to nondeposition of the Chugwater beds or to their removal by erosion in preMorrison times. As it is, the hiatus probably represents part of the later Carboniferous, the Permian, the Triassic, and all of the Jurassic periods. South of the Arkansas River some of the Chugwater beds probably appear again, although at present their identity is not established.

"The Badito formation of Hills appears to be simply the Fountain formation of Cross and Gilbert. The Sangre de Cristo formation to which Hills refers in the Walsenburg folio appears to represent a great development of Fountain (or lower Wyoming) deposits. It is stated that remains of an upper Carboniferous fauna and flora occur in this formation, which is added evidence as to the age of the lower Red Beds (Fountain-lower Wyoming) series. These beds overlie or merge into the basal limestone series on the eastern slope of the Sangre de Cristo (Culebra) Range, in which Mr. Willis T. Lee has discovered an extensive upper Carboniferous (Pennsylvanian) fauna.

"The Red Beds revealed in the canyons of the southeastern Colorado can not be classified with certainty from the present evidence. On Purgatory River and Muddy Creek the principal body of red beds is separated from the Morrison formation by gypsum or gypsiferous shales, strongly suggestive of the Chugwater (upper Wyoming) formation. It was immediately under this gypsum in Purgatory Canyon that I found the shoulder bone of a supposed belodont. Mr. Willis T. Lee has traced the Red Beds farther south into northeast New Mexico, where the gypsiferous horizon gives place to a massive sandstone, termed the Exeter sandstone, constituting the summit of the Red Beds, a member which may represent the distinctive top sandstone of the Chugwater formation in northern Colorado and in southern Wyoming. The sandstone is prominent in the Two Buttes uplift, constituting the summit of the Red Beds, and is underlain by red shales, which contain a thin bed of limestone, noted by Mr. Gilbert, strikingly like the Minnekahta horizon. I have not made observations on the Red Beds in Kansas and do not feel that a comparison of the published statements with my observations in the region north and west should aid in the correlation" (beginning p. I62). 


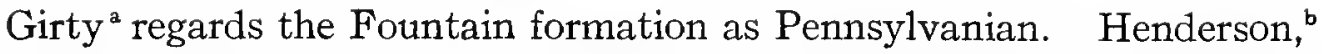
regarded the lower part as Mississippian and the upper as Pennsylvanian, and David White, ${ }^{c}$ from the evidence of fossil plants, would place it in Pottsville time.

In Professional Paper 53, United States Geological Survey, Darton speaks of the Red Beds of Colorado. He says that in southern Colorado the Red Beds lie on an irregular surface of granite, except in certain embayments, as the ones at Manitou and Canyon City, where lower Paleozoic rocks intervene. The Red Beds have been found to be an extension of the Red Beds underlying the Carboniferous limestone in southeastern Wyoming and of the Permian and overlying Red Beds of Kansas. ${ }^{-}$The Red Beds of this region he considers as divisible into three parts: (I) the Fountain or lower Wyoming (the lowest), consisting of coarse red grits which he found to represent the upper Carboniferous limestone of Wyoming; (2) the Tensleep sandstone, traced as far south as the Manitou embayment; (3) the gypsiferous red shale and sandstone of the Chugwater, which represents the Red Beds of the Black Hills and Wyoming. The lower part of the Chugwater he considers as Permian, the upper part as Triassic or Permian.

Lee ${ }^{\mathrm{e}}$ has described the Red Beds of southeastern Colorado and northeastern New Mexico. He found in southeastern Colorado a great thickness of red beds lying beneath a shale formation which he regards as Morrison in age. These beds extend as far south as the valley of the Canadian River in New Mexico, showing in the walls of the various canyons. The Red Beds, which he regards as of Permian or Permo-Carboniferous age, consist of many feet of red sandstone and shale lying unconformably beneath the Morrison shales. It is certain that in the Canadian Valley, from Tucumcari to the Conchas Canyon, the Red Beds are of Triassic age (plate I I and plate I2, figs. I and 2); this is shown by the contained fossils, phytosaurs and Unio, collected by the author. In the same beds Darton found the remains of a phytosaur on the Purgatory River in southeastern Colorado. The red beds as described by Lee terminate above the heavy beds of gypsum and gypsiferous clay, but near Folsom, New Mexico, he found a heavy red sandstone, the Exeter, lying unconformably upon the Red Beds. It is very probable that this sandstone extends farther south than is mentioned by Lee, as a heavy red sandstone equivalent to the Exeter in position is seen as far south as the north wall of the Canadian Valley near Montoya, New Mexico. Considering the evidence of the fossils discovered, it seems probable that the red beds described by Lee are Triassic in age.

a Girty, U. S. Geological Survey, Professional Paper 7I, pp. 369, 370.

b Henderson, Jour. Geol., vol., 16, pp. 491, 492, 1908.

- White, U. S. Geological Survey, Professional Paper 71, p. 370.

d The Red Beds of Kansas have since been shown to be continuous, in part at least, with the Permian limestones and not to overlie them.-E. C. CAse.

'Lee, Jour. Geol., vol. IX, p. 393, I901 ; Ibid., vol. x, p. 36, I902; Jour. Geography, vol. I, p. 35, 1902; Ibid., vol. II, p. 62, 1903 . 
CASE

PLATE 3

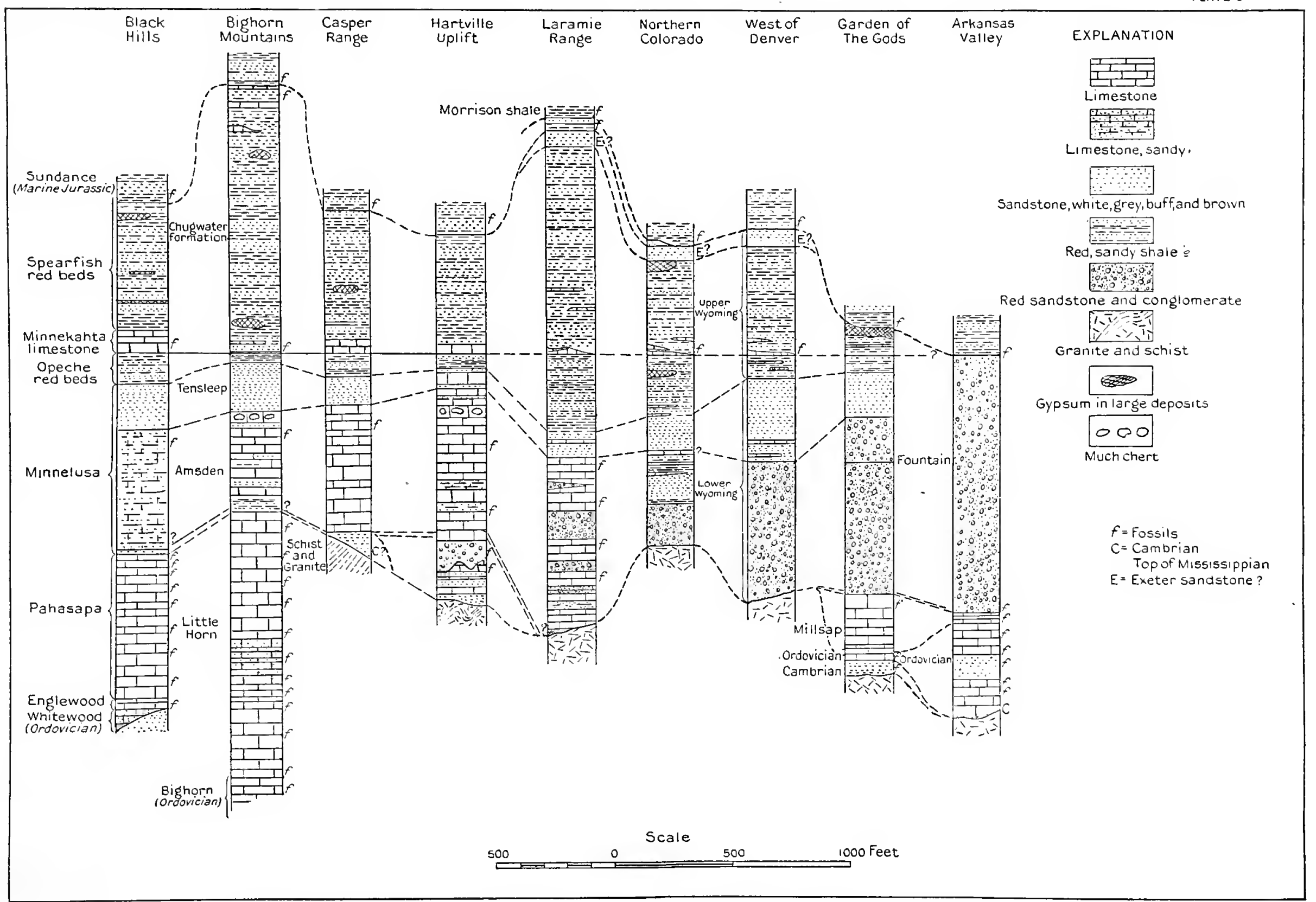

Chart of Columnar Sections of Carboniferous and "Red Beds" in the western part of the Plains Province. From Darton. This chart gives Darton's correlation of the beds, the author's exceptions are noted in the text. 

The following is a section given by Lee ${ }^{a}$ near Exeter Post Office, in the Canyon of the Rio Cimarron, northeastern New Mexico (abbreviated):

Dakota, hard quartz sandstone $\ldots \ldots \ldots \ldots \ldots \ldots \ldots \ldots \ldots \ldots \ldots \ldots \ldots \ldots$
Morrison (?) shale, sandstone and limestone $\ldots \ldots \ldots \ldots \ldots \ldots \ldots \ldots \ldots$
Shales.
Exeter, sandstone red and variable in color. $\ldots \ldots \ldots \ldots \ldots \ldots \ldots$
Unconformity.
Red Beds, red sandstone interstratified with red and purple shales.

Henderson ${ }^{b}$ in 1908 gave an account of the Permo-Triassic (?) of the foothills formations of northern Colorado. He distinguishes the upper part of the Wyoming as partly Permian.

"Lykins Formation.-Conformably overlying the Lyons is a series of variegated, mostly thin-bedded sandstones and shales, rather friable, chiefly deep red in color, with thin limestone bands, the upper part usually gypsiferous. In the Boulder district Fenneman names these beds the Lykins formation. It is the exact equivalent of the upper Wyoming of Emmons in the Denver Basin and the Chugwater of Darton in northern Colorado. In the Denver Basin monograph it is given a thickness of 485 to 585 feet, Fenneman makes it 800 feet in Four-mile Canyon, north of Boulder, and Darton gives it a thickness of 380 feet at Lyons and 520 feet at Owl Canyon. Though it varies greatly in thickness and in stratigraphic details, its general characters are constant throughout the region. As a whole the formation is non-resistant, the greater part being concealed by the débris in the lateral northsouth valleys caused by its destruction.

"From Owl Canyon to the Little Thompson I have mapped as part of the Lykins a more resistant sandstone, strongly cross-bedded, which forms a ridge in the valley and which sometimes extends nearly to the top of the east slope of the Lyons escarpment (plate $\mathrm{r}$ 8, fig. $\mathrm{r}$ ). It is difficult to distinguish from the Lyons sandstone, and should perhaps be assigned to that formation, but is uniformly separated from the latter everywhere north of the Little Thompson by strata lithologically resembling the Lykins. In approaching Little Thompson Canyon these intervening beds rapidly play out, bringing the sandstone which is mapped as Lykins into contact with the Lyons and making the former the crest of the escarpment, almost covering the latter. Thence southward it is doubtful if the two sandstones can be recognized as distinct formations, and nowhere have I found a noticeable unconformity. As the two sandstones after coalescing form an almost vertical escarpment, if they are distinct it is practically impossible to represent the Lyons on the map, yet northward they are quite distinct. The one which is mapped as Lykins in the northern region passes beneath the 'crinkled' sandstone of Fenneman's report, which is but a few feet above the Lyons north of Boulder. This problem is worthy of future investigation.

"In some places certain strata of the Lykins are very massive, though soft, and portions of the formation are locally calcareous, in addition to distinct limestone bands.

"In the absence of paleontological evidence this formation has been usually assigned to Triassic-Jurassic age. It seems quite likely, however, that the base of the Lykins may represent Permian time, as the immediately underlying Lyons is upper Carboniferous. The upper part of the Lykins is probably Triassic or Jurassic, as it is overlaid by known Jurassic in northern Colorado, though it is possible that part of the Jurassic and Triassic is represented by the general unconformity between the Lykins and the Morrison."

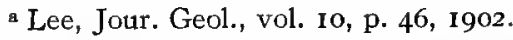

b Henderson, First Ann. Report Geological Survey of Colorado, 1908, p. I68. 
Butters " in I 913 gave a very detailed account of the "Permo-Carboniferous" of the eastern foot-hills of the Rocky Mountains in Colorado. After detailing the conditions in the various sections from the north line of Colorado south he says:

"Overlying this [the Ingleside] is the Lykins formation, and at one horizon about 200 feet from the base, at Heygood and Box Elder Canyons, Bellerophon crassus and Myalina subquadrata were found. The same species are found in the Fountain and Ingleside below. On this evidence, together with the fact that there is no angular unconformity, and no marked difference of lithological character, this basal portion of the Lykins is assigned to the Pennsylvanian period. On the northern slope of Table Mountain, Larimer County, 40 to 50 feet higher than the fossiliferous stratum, and separated from it by a gypsiferous series, another fossiliferous stratum occurs. This is probably more than 300 feet from the top of the Lykins formation and seems to be in the same stratigraphic position as the fossiliferous beds near Stout, and also those in the crinkled sandstone near Perry Park. At Stout, and also at Table Mountain, the 'crinkly' structure is not present. From this horizon Dr. G. H. Girty has identified the following fossils:

From Table Mountain: Myalina wyomingensis. Myalina perattenuata. Alula squamulifera. Murchisonia buttersi.
From Stout:

Myalina wyomingensis. Myalina perattenuata.
From Perry Park: Myalina wyomingensis. Myalina perallenuata. Alula squamulifera. Alula gilberti (?). Pleurophorus sp.

"This fauna has recently been discussed, Alula squamulifera and Murchisonia buttersi described as new, and Allerisma (Pleurophorella?) gilberti removed to the new genus Alula, by Dr. Girty.

"It will be seen that the faunas are essentially the same, and, while some of the species are new, the number of known forms is such that Dr. G. H. Girty believes a tentative correlation with the Rico formation of the San Juan region is justifiable. The Hermosa is Pennsylvanian, while the Rico is considered, tentatively, Permian. This leaves 100 to 400 feet of shales to represent the Permian or the remainder of the Permian, the Triassic, and all the Jurassic up to the Morrison. These sediments are usually a soft red shale or shaly sandstone, and the conditions of deposition were apparently unfavorable to the preservation of fossil evidence."

Later in the same article he says:

"Correlations.--The correlation of the Fountain, Ingleside, Lyons, and Lykins along the foothills from the line to Colorado Springs is a question of recognizing the same formation under different names. $* * *$ Thus the Fountain of Fenneman in the Boulder quadrangle is equivalent to the lower part of the Fountain of Cross in the Pike's Peak area. The Fountain, Ingleside, and Lyons together are equivalent to the lower Wyoming of the Denver Basin area. The Lykins is equivalent to the Chugwater of Darton and the upper Wyoming of Emmons. The upper portion of the Fountain and the Ingleside together are equivalent to Darton's Casper formation. The Lyons is equivalent to the creamy sandstone of the Denver Basin area, but Darton's Tensleep is not the equivalent of the Lyons and the Creamy sandstone. It is a lower horizon, and can be correlated only with the lower portion of the Lyons, and also the Ingleside. An explanation of this requires a description of 
the conditions in northern Colorado. This has been made under 'Formation names.' Darton's Tensleep in Colorado is probably in part equivalent to the sandstone-limestone series; that is, the Ingleside series.

"Owing to the absence of fossil evidence in the Badito formation, and from the fact that it is separated so widely from any recognized Fountain exposures, it has not been definitely correlated with the Fountain. Lithologically they are very similar, and the Badito overlies pre-Cambrian rocks unconformably, bearing about the same relation to the overlying formations as does the Fountain. On these grounds they are at least approximately in the same horizon.

"The Cutler formation is defined as that portion of the 'Red Beds' lying above the Rico, where that is present, or otherwise as succeeding the Hermosa and below the Dolores. The Cutler is assigned to the Permian purely on stratigraphic grounds, and is separated from the Rico by a purely arbitrary line. There seems to be as good ground for assigning the Lykins, above the crinkled sandstone, or at least the lower portion of it, to the Permian, and thus correlating it with the Cutler.

"Above the Cutler formation in the San Juan region is a series of sandstones, sandy shales and conglomerates which vary in thickness from 800 to 400 feet, and from that down to 30 feet at the San Miguel River, disappearing entirely north of this river. These shales and sandstones are a bright vermilion in color, and are known as the Dolores formation. They are assigned to the Triassic age because of the scanty, but widespread, vertebrate, invertebrate, and plant remains. The extreme upper part of the Lykins in Larimer County may be equivalent to the Dolores and thus be Triassic. If so, it is impossible to draw a line between the Permian and Triassic in eastern Colorado."

The following fossils were obtained by Mr. Butters from the Lykins formation :

Lower horizon: Myalina subquadrata, Bellerophon crassus.

Upper horizon (identified by Dr. Girty): Myalina wyomingensis, Myalina perattenuata, Alula squamulifera, Alula gilberti (?), Pleurophorus sp., Murchisonia.

"Of the Lykins fossils all except Alula squamulifera and Murchisonia buttersi, which are new species, and Alula gilberti (?) are found in the Rico formation of the San Juan region. Girty reports about 37 species from the Rico. Of these Bellerophon crassus and Myalina subquadrata and others also occur in the Hermosa. It will be noticed by the list of the Lykins fossils that these two occur at a different and a lower horizon in the Lykins than the remainder. This rather strengthens the correlation of the Lykins with the Rico. Bellerophon crassus and Myalina subquadrata are found in the Hermosa and other Pennsylvanian horizons lower than the Rico. Pleurophorus subcostatus and Pleurophorus occidentalis occur in several localities, but it is by no means certain that the Pleurophorus of the Lykins belongs to either one of these species. A doubtful identification of Myalina wyomingensis has been made from Leadville. With these possible exceptions none of the Lykins fossils have been reported by Girty from any formations in Colorado other than the Rico. In summarizing it will be seen that there is fairly good evidence for correlating the Lykins with the Rico, and no evidence for correlating it with any other horizon. The Lykins fossils were collected from localities a long distance apart-from the extreme northern part of Larimer County in the north to Perry Park in E1 Paso County in central Colorado-so that the Lykins appears to be more widely distributed than the Rico." 
While Mr. Butters correlates the Lykins with the Rico, he notes that the fossils occur in regions which were separated by a land area at the time of their deposition.

CONCLUSIONS.

From the facts brought together above, several interesting conclusions may be drawn. It is shown that in the Bighorn and Laramie Mountains the Carboniferous limestone shades into thin red beds, just as in Kansas, Oklahoma, and Texas, and that the same thing is probably true of the Black Hills and at least as far south as the north line of Colorado. Probably similar relations could be found from southern Kansas to the Bighorn Mountains were not the beds covered by later deposits. On the west, the upper part of the Red Beds, Chugwater in part and Spearfish, are generally regarded as Triassic, farther toward the south there is a distinction into upper Wyoming and lower Wyoming (Fountain) formations. Darton, as quoted, believes the upper beds to disappear a short distance south of the Garden of the Gods and the lower Wyoming (Fountain) to appear in contact with the Cretaceous or Jurassic, and with this the author is in accord. With many of the observations of Darton, the author, from recent study, is in full agreement, but he does not feel that the various beds, as the Minnekahta, Opechee, etc., can be recognized so confidently in many places as Darton appears to do. This is undoubtedly due in part to the author's lesser acquaintance with the beds in question, but he still feels that prolonged study would not render all of Darton's correlations entirely satisfactory to him, especially as there is so much of terrestrial deposition, with its concomitant irregularity of the beds.

The upper Red Beds of Colorado (upper Wyoming, Lykins) are grouped by Darton with the Chugwater and Spearfish, and he refers to them as partly Permian and partly Triassic. The lower portion of the Colorado beds is certainly Permo-Carboniferous. Butters, as shown above, has collected fossils from these beds which Girty calls "American Permian" (fide George), and this means practically the horizon of the Texas-Oklahoma beds. The author studied the beds from Red Mountain, near Laramie, to where they disappear south of Colorado Springs, with the greatest care, and, while no trace of vertebrate fossils was found, the lithological similarity to the beds of Texas and Oklahoma was so striking that, coupled with Butters's discovery of fossils, the suggestion that these beds were laid down in a continuation of the area of deposition in the south and under identical conditions is so strong as to be almost conclusive. Color, texture, markings, included concretions, and similar structures from one locality can be exactly matched in the other. The author is convinced that the Lykins formation, at least as high as the base of the pinkish, massive sandstone near its top (plate I7, fig. I), can be correlated directly with the beds of Texas, so far as the conditions of deposition and the continuity of the area of deposition goes. Whether the time of deposition was exactly the same in the two areas is not certain, but the 
time interval, whatever it may have been, was probably that involved in a progressive or regressive movement of the conditions which determined the deposits.

South of Pueblo there is a long, narrow strip along the east front of the Sangre de Cristo range which is marked on the geological map of North America as Permian, continuous with the Permian of the Pecos Valley. As already shown (p. 6o), the Triassic extends from the western edge of the Staked Plains well over eastern New Mexico. The Red Beds described by Lee and in part by the author are Triassic, from fossil evidence, and certainly a good part of the beds at Las Vegas Hot Springs are Triassic, as shown by the dinosaur tooth found by the author near the middle of the series just north of the Hot Springs (p. 6I). The relation of the beds at Hot Springs to those just south of the Garden of the Gods can be demonstrated only by a careful foot-by-foot traverse and a very tedious search for fossil evidence.

The author believes that there was a Permo-Carboniferous area of deposition reaching from north-central Texas to the Black Hills and west to the Front Range of the Rocky Mountains. South of the Garden of the Gods the western edge of this area seems to have bent to the east in the latitude of Las Vegas, or the deposits to have become very thin. How far this embayment to the east extended is very uncertain; in the valley of the Canadian River the Permo-Carboniferous Red Beds, Quartermaster and Greer, reach at least to the center of the Staked Plains, but do not appear on the western side. South of this they may have extended west to the Guadaloupe Mountains, as suggested by Beede. ${ }^{a}$

The material of the Red Beds in the north and west originated in the decay and erosion of igneous and early Paleozoic masses where now lie the Black Hills and Bighorn Mountains and a greater mass extending west from the present Front Ranges of the Rocky Mountains. The southern Red Beds were largely derived from the igneous and early Paleozoic masses in the position of the present Wichita Mountains and Arbuckle Hills.

Of this great area of similar deposits only a portion of the southern part is well exposed, and of that only a small portion carries vertebrate fossils. But we can at least attempt the delimitation of the whole area and show what lands may have been the source of the sediments and the home of the upland animals. (See plate 4 , opp. p. 88.) 


\section{CHAPTER III.}

\section{DESCRIPTION OF THE BASIN PROVINCE.}

The region yielding Permo-Carboniferous fossils, in Rio Arriba County, New Mexico, has already been twice described by the author and Dr. Williston. ${ }^{a}$ As shown by the faunal lists (p. 96), the animals of the Plains and Basin Provinces were quite distinct, not a single species and but a few doubtful genera being common to the two. Whether the deposits in the two provinces are of the same age or the western younger than the eastern is as yet undecided. Dr. Williston believes that the fauna from the New Mexican beds is more primitive, and so younger than that from Texas and Oklahoma. Dr. Schuchert is inclined to believe the New Mexican deposits younger from the evidence of the invertebrates. The Hueconian fauna of Girty ${ }^{b}$ is "quite different from those of the Pennsylvanian of the Mississippi Valley and are mostly undescribed." The Guadalupian life "is quite unlike the faunas of eastern North America, and almost equally unlike those of the West." Girty also remarks that the Hueconian fauna is likely to be found widely extended in the West.

In Wyoming there are two distinct faunas which are closely approximated, geographically. Knight found invertebrate fossils near Red Mountain, Wyoming (plate I6, fig. I), distinctly similar to those of the Kansas Permian (?) limestones, but farther west a different fauna occurs. In detail:

Near Red Mountain Knight ${ }^{\mathrm{c}}$ found, 728 feet above the base of his section, a fossiliferous layer of "grayish to reddish sandstone containing the following genera of fossils: Allorisina, Pleurophorus, Bellerophon, Myalina, Aviculopecten, Dentallium (?), Pleurotomaria (?), several small gastropods, and some remains of vertebrates. $* * *$ The genera (in the fossiliferous layer in this section) are so characteristic that it is unnecessary to discuss their geological position; they belong to the Paleozoic and resemble to a marked degree the fossils of the Kansas and Nebraska Permian." (Plate I6, figs. I and 2, and plate I7, fig. 2.)

In the Park City mining district Bartwell ${ }^{\mathrm{d}}$ distinguished three formations, the Woodside, Thaynes, and Ankareh:"

"The Woodside is a fine-grained unfossiliferous red shale 700 to $\mathrm{I}, \mathrm{I} 80$ feet thick, which overlies unconformably the Park City formation (Pennsylvania). The Thaynes is characteristically calcareous and rich in fossils. It is $I, I 90$ feet thick. In

${ }^{n}$ Williston and Cisse, Jour. Geol., vol. xx, p. I, 1912; Carnegie Inst. Wish. Pub. I8I, p. I, 1913.

${ }^{b}$ Girty, U. S. Geological Survey, Professional Paper No. $5^{8 .}$

"Knight, Jour. Geol., vol. 10, p. 419.

d Bartwcll, Jour. Gcol., vol. I5, I967, p. 439.

- Quritud from U. S. Geolugical Survey, Professional Piper No. 7I, p. 494.

72 
I907 Girty reported that the fauna and horizon are those which in the Fortieth Parallel Survey reports are called Permo-Carboniferous, and said: "It seems probable that the fauna will be correlated with the Permian of the Grand Canyon section.' "

Girty later referred these fossils to the Triassic and "almost certainly equivalent to the Triassic of Idaho." His latest statement, in I9Io, ${ }^{a}$ seems to indicate his belief that there are deposits of Permian or Permo-Carboniferous age in this region. He says:

"In notable contrast to the Weber formation, the beds above the Park City formation show striking persistence in their main lithological and paleontological characters. These are the 'Permo-Carboniferous' beds of the King survey and were divided by Boutwell in the Park City district into the Woodside, Thaynes, and Ankareh formations. It seems all but certain that the 'Permian' of Walcott's section in the Kanab Canyon, in southern Utah; the 'Permo-Carboniferous' of the Wasatch Mountains in northern Utah; and, in part, the 'lower Triassic' of southeastern Idaho are one and the same series. The Woodside, Thaynes, and Ankareh do not, perhaps, maintain precise boundaries throughout all this territory, and in Idaho the first occurrence of Triassic ammonites (Meekoceras beds) is conventionally taken as the base of the Thaynes.

"'The Triassic age of at least the major portion of the 'Permo-Carboniferous' (Thaynes and Ankareh) seems to be shown by fairly satisfactory evidence- the presence of an extensive ammonite fauna of Triassic type and the practical absence of any distinctive Carboniferous forms. In advance of a detailed study of these faunas, however, it may be pointed out that above the Meekoceras beds there are zones which contain great numbers of Rhynchonella closely related to the Carboniferous Pugnax utah and many specimens of apparently true Myalina, not unlike Carboniferous species.

"It is much less certain that the Woodside formation is not Paleozoic (Permian?). A preliminary study of the Woodside shows that, except that it has yielded no ammonitic forms, it does not differ materially from the fauna of the Thaynes and presents a strong contrast to the Carboniferous fauna of the Park City. Lithologically also there is a well-marked division between the Woodside and the Park City formation, and no lithological boundary can be traced between the Woodside and the Thaynes. That the Woodside, Thaynes, and Ankareh form a natural group is indicated by the classification of the rocks adopted by most geologists. If the Thaynes is Mesozoic, the obvious line between the Mesozoic and the Paleozoic would seem to be the line between the Park City and the Woodside. If, then, as may be tentatively concluded, the Woodside does not represent the Permian, the natural question to follow is: Does the Park City formation belong in the Permian? A decisive judgment on this point should wait upon a careful study of the faunas obtained from other members of the Park City beds, as well as upon a study of other related faunas less certainly appearing at the same horizon. Because of the close relationship or identity of many species of these faunas with the Gschelian faunas of Russia, I am provisionally holding that the Park City formation is older than the Permian.

"Any one at all familiar with the Carboniferous faunas of the Mississippi Valley will at once recognize that the forms found in the phosphate beds, individually as well as collectively, are quite different from the forms found in that area."

a Girty, Bull. U. S. Geological Survey No. 436, pp. 7-10, I9Iо. 
In further remarks in the same paper Girty suggests the possibility that the beds under discusion, together with many other beds in the western part of the United States, may be found to be Gschelian in age.

Girty ${ }^{\circ}$ regards the invertebrate collected by Darton in Gilmore Canyon (270 feet above the 24 feet of limestone in the Casper) "as very closely related to that of the upper part of the Pennsylvanian division in the Kansas section."

The Forelle limestone and Satanka sandstone above the Casper south of Laramie are in part gypsiferous. It was in the former that Knight's fossils were found." According to Girty, the fauna is "late Pennsylvanian or possibly equivalent to the Wreford limestone in the so-called Permian of Kansas." These two beds are separated from the Chugwater by the Carboniferous character of the fauna, "otherwise it might be regarded as a portion of the Chugwater formation from near Laramie and Red Buttes. The stratigraphic succession is strongly suggestive of Minnekahta limestone lying on Opechee red shale. The latter limestone occurs on the east side of the Laramie Mountains and in the Black Hills, and contains 'Permian' fossils in the sense in which the Permian is used in the Mississippi Valley. The Forelle limestone may possibly represent the Embar formation."

A little farther west and south on the west side of the Bighorn Mountains the Embar limestone occurs in the Owl Creek and Wind River Mountains and eastward.

From the walls of the Bighorn Canyon Girty determined Spiriferina pulchra, which "is believed to characterize a horizon just below the so-called Permo-Carboniferous of the Wasatch Mountains region," and, as Dr. Girty correlates the latter with Permian of the Grand Canyon section, the occurrence of these fossils in the Embar limestone suggests that this formation is equivalent to the upper Aubrey limestone of northern Arizona. According to Girty:

"The Embar limestone has a very different fauna from the Kansas Permian, but it may be equivalent to it or even later. The fauna is not related to the Guadalupian. It occurs in Utah just below the Permo-Carboniferous and is known also in Idaho and Nevada."

West and north of the Permian deposits in Rio Arriba County, New Mexico, is a large series of red beds which undoubtedly contain Permian or Permo-Carboniferous series deposited in the Basin Province. Cross and Howe have described the formations around Ouray, Colorado, separating the Cutler formation as Permian from the Dolores (Triassic) above and the Rico and Hermosa (Pennsylvanian) below. An unconformity separates the Dolores from the Cutler, but there is no stratigraphic break between the Permian and Pennsylvanian. The description given by Cross and Howe

"Girty, in Darton, Bull. Geol. Soc. Amer., vol. 19, p. 429.

b Darton, Bull. Geol. Soc. Amer., vol. 19, p. 43 I ; Knight, Jour. Geol., vol. x, p. 419.

- Cross and Howe, Bull. Geol. Soc. Amer., vol. 16, p. 46I, 1905.

d Cross and Howe, Bull. Gcol. Soc. Amer., vol. 16, p. 46r, I905; see also U. S. Geological Survey, Professional Paper No. 7I, p. 480. 
of the Cutler and adjacent formations shows them to have the same character as other Permo-Carboniferous beds, but to include larger pebbles and coarser fragments, indicating the proximity of at least a local source of supply in the Basin Province.

Similar deposits are found to the north in west central Colorado. ${ }^{\text {a }}$

Farther west the Permo-Carboniferous of the Uintah and Wasatch Mountains carries marine invertebrate Spiriferina pulchra, Myalina, Aviculopecten, etc., so it is possible that the Red Beds bordered an open sea, which extended to the west. The Permo-Carboniferous of these mountains are, according to Girty, equivalent to Walcott's Permian in the Grand Canyon. ${ }^{\mathrm{b}}$

Permian beds have also been determined in the Zuñi Plateau of New Mexico by Dutton, " which correspond in lithological character and fossils with those determined by Walcott in the Kanab Canyon and are terminated above by the coarse basal, Triassic, Shinarump conglomerate.

Darton $^{\mathrm{d}}$ regards the Moencopie of Ward in northeastern Arizona as Permian. Walcott ${ }^{\mathrm{e}}$ located Permian deposits in Kanab Canyon of northeastern Arizona. ${ }^{f}$ The occurrences here mentioned show the typical character of red beds, and the few fossil invertebrates collected point to their Permian or Permo-Carboniferous age. The beds are not described in detail, for as yet no vertebrate fossils have been found in them, and the object of the present chapter is only to show the probable outlines of the Basin Province. ${ }^{\mathrm{g}}$

The original papers are easily accessible and the essential parts of the discussion are repeated in Professional Paper No. 7 I, United States Geological Survey, pages 479-486.

Professor Gregory, in conversation with the author, stated that the Shinarump conglomerate does not occur east of the western edge of New Mexico (Mount Taylor and Fort Wingate regions). As this is a strong and very

a Cross, Geolog. Atlas of the United States La Plata folio (6o); Silverton folio (I20).

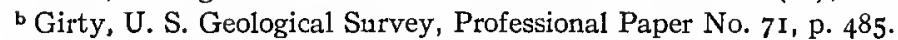

"Dutton, Sixth Ann. Rpt. U. S. Geological Survey, 1885.

d Darton, Bull. U. S. Geological Survey, No. 435, pp. 32-36, 1910.

- Walcott, Amer. Jour. Sci., 3d series, vol. 20, pp. 22 I-235, I 880.

I Dr. Girty informs the author that a portion, at least, of Walcott's Permian has been shown to be Triassic by the discovery of typical cephalopods.

$\mathrm{g}$ In the summer of 1913 the author, accompanied by Mr. Emery of Yale University, discovered impressions of a conifer in the lower part of the Moencopie, a few miles west of Fort Defiance, Arizona. These specimens were submitted to Mr. David White, who gives the following report upon them:

"The large fragment with closely placed lateral twigs belongs to another Walchia resembling the Walchia hypnoides. It is perhaps identical with that described by Dawson as Walchia gracilis. One or two small fragments in one of the loose rock pieces agrees still more closely with Walchia gracilis. These forms of Walchia are characteristic of the Permian, and are present in Oklahoma and in the Wichita formation of Texas."

A few days later the author found the interclavicle of a large stegocephalian in a bed of conglomerate 20 feet below the base of the Shinarump conglomerate, but still well within the Shinarump formation, as it is now regarded by Gregory (letter from Dr. Gregory to the author), at Tucker's Spring, about Io miles northwest of Winslow, Arizona. This interclavicle closely resembles that described by Lucas as Metoposaurus fraasi from near Tanner's Crossing on the Little Colorado River. It is probably a form nearer to Anaschisma, a typically Triassic form. Lucas described another fossil from near the locality where his Metoposaurus was found and called it Placerias, referring it to the Cotylosauria. Broom, in conversation with the author, stated his belief that this fossil belonged to the South African group, Dinocephalia. 
widespread formation in southern Colorado, Arizona, and western New Mexico, its absence at all points east in the same latitudes is of considerable significance.

The limits of the Basin Province are less certain than those of the Plains Province, but it is certain that the area of Red Bed deposition of PermoCarboniferous time covered northern Arizona and New Mexico and extended north through western Colorado into Wyoming. Its western side seems to have terminated in a limestone-forming sea covering the site of the Uintah and Wasatch Mountains, and its eastern side rested against the land-mass which separated it from the Plains Province.

Opposed to the proposition of a separate (Basin) area of deposition is the discovery by Weeks ${ }^{\text {a }}$ of certain fossils on the southeast slope of Hamel's Peak, some miles south of Ely, Nevada, which Girty determined and regarded as of a "similar fauna to that of the Marion formation of the Kansas section, which Prosser regards as a Lower Permian fauna, and it can probably be safely correlated with the Marion." The list is:
Productus sp.
Nuculana cf. obesa.
Bulimorpha peracuta.
Pleurophorus? sp.
Murchisonia, near marcouiana.
Schizodus sp.
Straparollus catilloides.
Bellerophon sp.
Dimatoceras sp.
Pleurotimaria humerosa.
Ostracoda.
Bakewellia parva.

The lowest beds observed in Arizona and New Mexico, San José region, occur in the axis of an anticline 8 miles west of Rio Puerco Station, 20 feet of greenish-gray shales with thin sandstone layers and an inch of coal at top. Fossils from this locality are given by Darton ${ }^{\text {b }}$ as:
Myalina perattcnuata.
Myalina permiana.
Aviculopecten cf. A. whitci.
Bakewellia (?) sp.
Bullimorpha, near B. nitidula.
Spirorbis sp.

These are related to the Permian fauna of the Mississippi Valley.

Keyes ${ }^{c}$ says that red beds of the Bernalillo shale nearly I,ooo feet thick occur in the Sandia Mountains above the dark-blue and black limestone and carry abundant fossils which "correspond faunally with those found in the upper part of the Oklahoman series of Kansas." He refers to the Report of the Governor of the Territory of New Mexico to the Secretary of the Interior, page 339, I903. This report does not mention fossils in the Bernalillo shale, but does in the blue and black limestone below, referring them to Carboniferous of the Mississippi Valley.

The evidence here cited is not sufficient to raise a great objection to the existence of separate basins of deposition. It is very possible that there may have been short and local extensions of the seas of the Plains Province to the west.

\footnotetext{
"Spurr, Bull. U. S. Geological Survey No. 208, p. 52, 1903.

${ }^{b}$ Darton, U. S. Geological Survey, Bull. 435, p. 37, 1910.

"Keyes, Iowa Acad. Sci., vol. 15, p. 144, 1908.
} 


\section{CHAPTER IV.}

\section{DESCRIPTION OF THE PERMO-CARBONIFEROUS BEDS IN EASTERN NORTH AMERICA.}

1OWA.

East of the beds in Texas, Oklahoma, and Kansas, no vertebrate fossils of Permo-Carboniferous age have been found closer than Illinois, but certain deposits in Webster County, Iowa, have been doubtfully referred to the Permian, and more or less directly correlated with the western deposits.

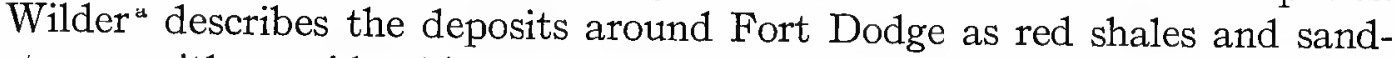
stones, with considerable gypsum lying unconformably upon the St. Louis limestone.

The narrow sea in which was deposited the Wreford and overlying limestone in Kansas and southern Nebraska probably did not extend much farther east than Ozarkia, though its easternmost deposits have been removed by erosion. To the north it may have extended into southwestern Iowa (see Schuchert's Paleogeographic map of the Late Permian), and even into northwestern Missouri.

The author has recently examined the beds in the vicinity of Fort Dodge, Iowa, and found nothing either in the character of the material or the mode of deposition which would warrant the assumption that they were in any way connected with the Red Beds deposits farther west. The red and particolored clays and shales have in many places the appearance of residual clays formed by the decomposition of a limestone. There can be little doubt that they were formed in the last part of the Paleozoic and so may, perhaps, be reckoned as Permo-Carboniferous, possibly formed at the same time as the Red Beds, but under radically different conditions, either as the result of mature decomposition of the land surface east of the Permo-Carboniferous sea or in some inland body of swampy water.

East of Iowa no deposits referable to the Permo-Carboniferous are found nearer than eastern Illinois. This is easily understood when we reflect how long the region had been exposed to erosion, and how slight and thin must have been the deposits, which were essentially terrestrial or fluviatile, or perhaps occasionally lacustrine.

\section{ILLINOIS.}

The nature and exact age of the limited deposits near Danville, Vermilion County, Illinois, is still doubtful. The suggestion by Baur and Case, following Cope, that they are accumulations from a Permian river which excavated its channel in the Pennsylvanian limestone has been questioned by

a Wilder, I2th Annual Report, Geological Survey of Iowa, p. 63I. Norton and others. Underground Water Resources of Iowa, U. S. Geological Survey, Water Supply Paper No. 293, p. 86. 
Williston and Weller, though the existence of just such deposits, the Merom sandstone, in closely adjacent regions in Indiana lends considerable support to the suggestion. The later recognition that the age of the vertebrate fossils is much greater than was originally supposed, and that they must be considered as Permo-Carboniferous rather than Permian, removes the need for such an hypothesis, in large measure. Concerning these beds, I quote from a letter from Dr. Williston, of April I8, I9 12:

"We found fossils on practically the same horizon, about 300 feet distant, lying above a limestone layer, whose horizon was definitely fixed as Pennsylvanian. The fossils occur in a clay bed almost precisely like that of the Baldwin quarry [a black, soapy clay-Case], near the water's edge and about Ioo feet below the top of the bank of the river. In my inspection I felt pretty confident that the fossils lie in their original undisturbed position. Weller is inclined to believe that the clay beds have slipped down from a higher altitude. If they are in their original position they certainly are 200 or 300 feet, at least, below horizons which are clearly Pennsylvanian. There is not the slightest evidence of an unconformity or any old 'Permian' river channel. If Weller is correct, the fossils may have come from near the top of the Pennsylvanian, but still distinctly Pennsylvanian. If my opinion is correct, they are a considerable distance below the top of the Pennsylvanian."

\section{INDIANA.}

It would be idle in the present state of our knowledge to speculate upon the condition of the eastern part of the Mississippi Valley in late Pennsylvanian and Permian times, but we can at least be certain that it was exposed to erosion, and deeply trenched in places by large streams. Definite remains of such are found in Indiana. Some of these old stream-channels preserved as the Merom sandstone have been described by Blatchley and Ashley in the Annual Reports of the Indiana Geological Survey.

"The Merom Sandstone: Division IX.-Just as the main body of the Coal Measure is underlain with unconformability by a massive sandstone, so it is also overlain with unconformability by a massive sandstone. In the earlier reports this sandstone was designated the 'Merom Sandstone,' from its excellent exposure at that point. It there, as in the counties to the south, lies on an eroded surface of the Coal Measures, its lowest member consisting of a calcareous conglomerate containing shale, coal, pebbles of sandstone, etc. To the north, in Parke and Fountain Counties, and Vermilion County, Illinois, occur a number of extensive channels cut down into the Coal Measures to a depth ranging up to 200 feet, and filled with a sandstone very similar in many respects to the sandstone at Merom, Sullivan County. Though no such readily distinguishable channels were found in the southern part of the coal field, the position of the sandstone there, relative to the coal below it, indicates extensive erosion. If we are correct in correlating the massive sandstone of the channel fillings in the north part of the coal area with the overlying massive sandstone of the southern part of the area, it would appear that this sandstone was laid down at no inconsiderable time after the laying down of the Coal Measures proper. The great depth and width of the stream-channels cut out of the Coal Measures prior to its deposition suggest a long time interval. So far as known, no fossils have

\footnotetext{
alatchley and Ashley, Geological Survey Indiana, vol. 23, pp. 80, 8I.
} 
been found associated with this sandstone in Indiana. In Illinois, however, some fossils were some time ago found in some shale thought to be of the same age as the Merom sandstone. The possible Triassic age of the fossils led Mr. Collett to suggest that the Merom sandstone might be of the Triassic age. Concerning these fossils he says: 'Adjoining this locality (section 25, Township 19, Range r3, Vermilion County, Illinois) Dr. J. C. Winslow, of Danville, Illinois, discovered a bed of fossils which is named in his honor "Winslow Bluff." They occur in a bed of black, brown, gray, red, and pink shales, backed with sandstone, filling a depression denuded by forces acting at the close of the coal age, which has carried away the regular deposits, including probably three seams of coal." "

"We can only say, at this time," the question is still an open one. If the correlations of the channel sandstones of Parke County, which fill channels which cut down to and through Coal III, correlate with similar sandstone of Illinois, and with western Indiana, then it will be seen that previous to their laying down, the Coal Measures of the State have been tilted at an angle that would place nearly their whole thickness above sea-level in Parke County, while a score, or a little over, of miles away to the southwest, nearly the whole of the Coal Measure column, as preserved in the State, seems to have been under water. The exposed conditions of the eastern part of the measures seem to have resulted in the strata from Division VI up having been carried away, with valleys extending down into the measures to Division III."

"Coxville Sandstones (Merom?) : "Not only are channels cut down through the measures, but there appears to have been extensive, though shallow, erosion for some distance either side of the immediate channel, also filled with sandstone. The evidence points to either a short time after the laying down of Coal VI, or to a time entirely subsequent to the deposition of the Coal Measures proper; or at a time corresponding with the laying down of the Merom sandstone of Sullivan County. The latter theory is considered as best sustained." .

"In the east of Raccoon Creek, ${ }^{c}$ opposite Coxville, is the exposure of a sandstonefilled erosion channel, which has been given the name of Coxville Carboniferous River. As this sandstone was, by the old survey, considered to be a ridge of Mansfield sandstone, the following sketch (fig. I 2) is given, showing the true relations.

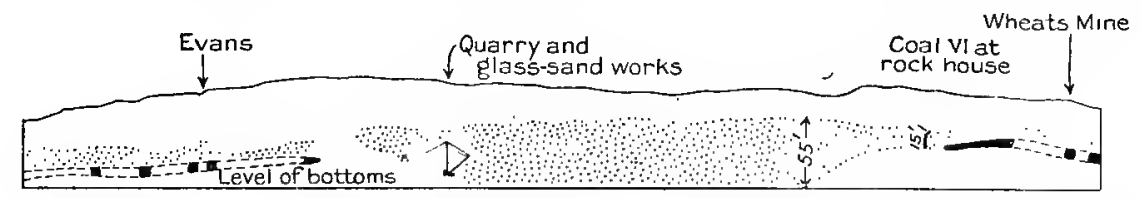

FIG. I2.-Diagram showing rock exposure across Raccoon Creek from Coxville, Indiana, to show relation of Coal VI to sandstone at the crossing of the "Coxville Carboniferous River." (After Blatchley and Ashley.)

"The channel proper is some 600 feet broad and exposed to a depth of at least 40 feet, and how much deeper is not known. The sandstone of this filling is massive, hardly showing a suggestion of bedding. Toward the west side is a little of the appearance of cross-bedding, or perhaps more closely resembling sand-dune structure. Above this 40 feet of exposed channel the sandstone rises without perceptible break or change another i 5 feet, but now spreads out on either side. On the east. side this can be traced some Ioo feet or so, by a clean exposure, to a rock-house,

- Blatchley and Ashley, 23d Annual Report State Geologist Indiana, p. 82.

b Blatchley and Ashley, 23d Annual Report State Geologist Indiana, p. 300.

- Blatchley and Ashley, 23d Annual Report State Geologist Indiana, pp. 385, 386. 
where Coal VI is seen immediately underlying the sandstone. On the west the extension of this upper sandstone can be traced some distance, though poorly exposed for the first I 50 yards, and there, too, it immediately overlies Coal VI. The age of the sandstone is thus put as late as the age of the horizon of Coal VI. Farther south there is commonly met with a nonconformability a little above Coal VI, and accompanying measures are often cut out and replaced by sandstone. The erosion is both of the channel and broad-wash order, the channels having been noted as much as $\mathrm{I} 6$ feet deep. It, however, seldom does more than remove the top of the coal, and not a single instance is recalled of its having cut through and below the coal. There is, thus, some evidence suggesting that the sandstone at Coxville belongs to the period of Division VI, but there is also some evidence that it belongs to a much later period. If, as has been suggested, this is a part of the same channel, or system of channels, as at Silver Island, Rockport, Mecca, and other places to be mentioned, it has cut channels I 50 feet or more deep, extending almost, if not quite, through the measures. Such channels require some time for their cutting, and it would seem as though, if this took place during the time period of Division VI, there should be more general evidence of a marked conformity than there is. The assumption of an unusually large uplift in the northeastern part of the coal field during that period might in part explain its absence elsewhere. For the present the question must remain an open one. The course of this channel was not discovered, but it appeared to cross the creek near Coxville, and go west, or south of west, coming from the north."

"Coal Measure on Sugar Creek. - The coals in this district are comprised in sections $23-26,35,36$.

"The coal in this district is very irregular, due apparently to this being in the path of the old Coxville Carboniferous River, met with at Silverwood. Not enough detailed work was done to settle this question definitely, but from what was noted we were led to surmise that the old river-channel crossed Sugar Creek at Rockport. The resemblance of the sandstone filling to the Mansfield sandstone exposed both up and down the creek, and the failure to find just the data needed, render this opinion somewhat doubtful. There are, however, some outside data that tend to confirm that theory; principally, that this old filled channel is plainly exposed at Silverwood, and the appearance of certain sandstones in section 5 of this township indicates that the channel was not very far away. Evidences of it are next met to the south along the middle course of Roaring Creek, and in the region of Sand Creek. Rockport is in the line between these places, and is, moreover, the only place along Sugar Creek where such a crossing appears to have taken place."

OHIO.

In eastern Ohio and Kentucky and in western West Virginia and Pennsylvania the middle Conemaugh beds resemble in many characters the Red Beds of Texas and New Mexico, and in both Ohio and Pennsylvania remains of reptiles and amphibians have been reported. In Pennsylvania the remains have been shown to be very similar to those found in Texas and Illinois; in Ohio very primitive forms, Eosauravus copei Williston, have been found at Linton, with numerous Amphibia, and other as yet undescribed forms have been found in other horizons.

- Blatchley and Ashley, 23d Annual Report State Geologist Indiana, p. 345. 
Condit ${ }^{\text {a }}$ describes the general outline and condition of these deposits:

"The Conemaugh formation outcrops in a broad band, Io to 20 miles wide, across the southeastern part of Ohio, and extends eastward, under cover, into West Virginia and Pennsylvania, again rising to the surface towards the eastern edge of the Appalachian coal basin. The strata included within this formation lie between the base of the Pittsburgh and the top of the Upper Freeport coal, and have a thickness in Ohio of 355 to nearly 500 feet. The area of outcrop *** extends eastward across Pennsylvania around the northern margin of the Appalachian coal basin, thence southward through western Maryland and eastern West Virginia. From southern Ohio the exposures may be traced into eastern Kentucky and West Virginia. Hence, it is evident that, structurally, the 'Coal Measures' area of Pennsylvania, Maryland, West Virginia, Kentucky, and Ohio is a broad synclinal basin, into which the rocks slope from the margin. The gentle southeasterly dip in Ohio is persistent for a distance into West Virginia, carrying the Conemaugh strata hundreds of feet below drainage, but beyond the middle of the basin the rocks rise again to the surface.

"As to the lithological character, the formation consists mostly of sandstone, sandy shale, and clay, much of which has a reddish-brown color. Coal seams and limestones are few and thin. All the beds are characterized by lack of persistence, and vary greatly as to thickness and appearance from place to place. Local erosion planes and unconformities of small magnitude are extremely abundant and occur at all horizons. The hiatuses are shown by conglomerates and truncated strata. Frequently the material of the conglomerates can be traced to some nearby fossiliferous limestone bed or coal-seam.

"Much of the lower half of the Conemaugh formation is of marine origin and has a number of fossiliferous horizons. The highest fossil-bearing beds, lying a little above the middle, mark the final invasion of the sea into the Appalachian Basin. All the overlying strata lack forms of undoubted marine origin, the fossils being mostly plant remains, certain minute fossils, such as Spirorbis, ostracods, and gastropods, generally regarded as fresh-water, together with occasional fish, amphibian and reptilian bones. Insect remains are sometimes found well preserved in the shales. The marine limestones of the lower half of the formation are the most persistent and lithologically uniform beds, but these have suffered contemporaneous erosion and locally failed to form, owing to the unfavorable conditions, such as the presence of shoals in the sea and continuous sedimentation from rivers."

Condit ${ }^{b}$ gives the following list of the beds in the Conemaugh formation in Ohio and their equivalents in West Virginia:

OHIO.

West Virginia.

Pittsburgh limestone.............. Upper Pittsburgh limestone.

Little Pittsburgh coal (upper).

Bellaire sandstone.

Lower Pittsburgh sandstone.

Little Pittsburgh coal (lower).

Summerfield limestone............. Lower Pittsburgh limestone.

Connellsville sandstone.............. Connellsville sandstone.

Little Clarksburg coal............. Little Clarksburg coal.

Clarksburg limestone............ Clarksburg limestone.

Morgantown sandstone.............. Morgantown sandstone.

Elklick coa1.

Elklick limestone.

Birmingham shale.............. Birmingham shale.

Skelly limestone.

Ames limestone............... Ames limestone.

a Condit, Conemaugh Formation in Ohio, Bull. I7, Geol. Sur. Ohio, p. I4, 1912.

b Condit, Geol. Sur. Ohio Bull. 17, p. 20, 1913. 


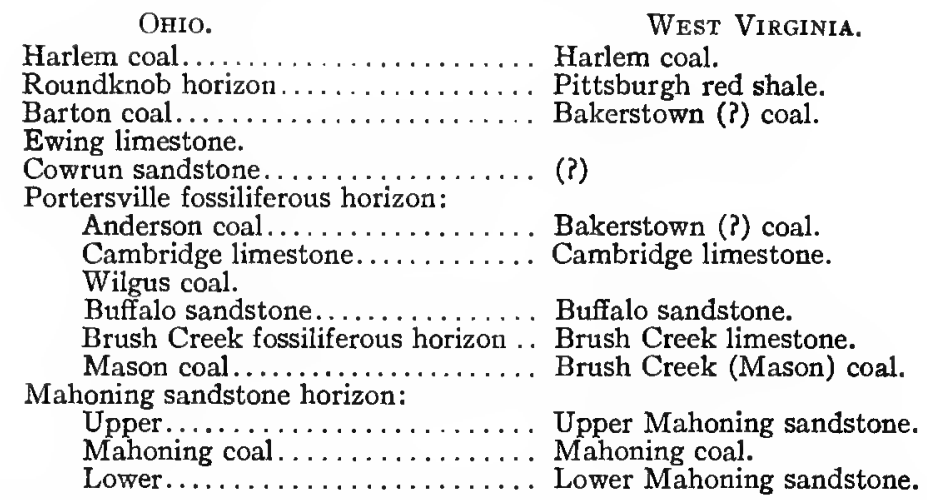

Of these formations only the Birmingham shale, the Round Knob Formation, and the Ewing limestone have yielded remains of reptiles or amphibians.

The Birmingham shale was named by Stevenson from its position near Birmingham, a suburb of Pittsburgh, Pennsylvania. It lies here 30 feet above the Ames limestone and is from 35 to 50 feet thick. A thin coal-seam at the base has been named by Raymond the Duquesne coal. Just above this coal are found plants, Estheria and fish teeth (Diplodus).

"This shale is also present in Ohio and, as at Allegheny, has a thin coal (Duquesne of Raymond) marking the lower limit. The Elklick coal of Pennsylvania and West Virginia sections is wanting in Ohio, hence the upper limit of the Birmingham is not definite. Immediately over the Duquesne coal is a persistent fossiliferous limestone, which is named the Skelly, from exposures at Skelly Station on the Pennsylvania Railroad, in Jefferson County, about so miles west of Mingo Junction. This bed is 25 to 40 feet above the Ames limestone and occurs nearly everywhere in eastern Ohio, excepting where replaced by massive sandstone $* * *$.

"In addition to the marine fauna, the shales have also insect and reptilian remains. The cockroach fauna from near Richmond, Ohio, collected by Samuel Huston, of Steubenville, and described by S. H. Scudder in Bulletin I24 of the United States Geological Survey, is accounted for as coming from shales a little above the 'crinoidal limestone.' It is probable that this material is from the Birmingham horizon. Professor Scudder lists 22 species from this locality, belonging to the genera Etoblattina, Gerablattina, and Poroblattina, I 7 of which are of the genus Etoblattina. A long list is also given from Cassville, West Virginia, collected from the base of the Dunkard formation, and Professor Scudder ${ }^{b}$ remarks that, although this locality has no species in common with the Richmond, Ohio, locality, there is a remarkably close relation in the material from the two places.

"The replacement of the shale by the Morgantown sandstone has already been commented upon in the description of that bed. This has taken place over much of the eastern part of the State, and the fossiliferous shale is rendered very irregular by numerous patches of coarse sandstone. The relation of these beds would indicate that the shale and sandstone are of contemporaneous origin. The sandstone is probably an estuarine or delta deposit, laid down at the same time that sedimentation of clays and silts was taking place in the neighboring salt-water lagoons.

"Toward the southern part of the State there is an increasing amount of red clay and shale above the Ames limestone, and in many localities these beds, together with the thin-bedded sandstone, constitute almost the entire Ames-Pittsburgh interval.

\footnotetext{
- Condit, Bull. 17, Geol. Sur. Ohio, p. 27.

B Scudder, Bull. U. S. Geological Survey No. 124, p. 12.
} 
"The Round Knob Formation.-This name is applied to the formation previously called the Pittsburgh Red Shale by I. C. White. A typical section is shown in Madison Township, Columbiana County, Ohio, near the cross-roads in section 15 .

"The beds vary from structureless, purplish-red clay to deep red even-bedded shale, which may alternate with bluish layers. The more sandy portions frequently show ripple-marks and sun-cracks. Lenticular siderite concretions are common in the bluish shales and nodules of limestone and hematite in the structureless red clay. The hematite is in dense, reddish nuggets of submetallic lustre, which contain 55 to 60 per cent of iron and would be of value as iron ore were the quantity greater. Land-slips are common in the Round Knob horizon; hence the soft red clay becomes distributed over a great vertical range, thus giving an appearance of considerable thickness.

"There has been much dispute as to the cause of the red color in the 'Coal Measure' beds. That it is in the case of the Round Knob horizon original rather than a secondary phenomenon due to the reactions of weathering is evident, since the redness is persistent where the beds are hundreds of feet below the surface, as is shown by drillings. Such colors are entirely wanting in the lower beds of the Pennsylvanian series, and appear near the middle of the Conemaugh for the first time. It is true that reddish tints are seen in a few horizons in the lower third of the formation, but these are largely secondary, or, in other words, the result of weathering, and only appear at or near the outcrop. It is probable that the change in climate, together with varied sources of supply of the sediments, are largely responsible for the red beds.

"The Ewing Limestone. a - Beneath the Barton coal is clay and more or less limestone in the form of nodular layers. The limestone is much more persistent than the coal and is found nearly everywhere except in places where it has been eroded and its horizon occupied by the sandstone. Ordinarily, there is only a nodular layer a foot or so thick, or a single course of limestone less than 2 feet, but here and there in the eastern part of the State are areas where the limestone attains a thickness of 5 to ro feet and consists of a number of layers interlain with clay. ***

"Fossils of types generally regarded as fresh-water are abundant in the Ewing limestone. Spirorbis is the most numerous of these, and ostracod carapaces are next in abundance. Fish-teeth are not uncommon and reptilian bones are also present.

"Along the lower Symmes Creek Valley, in Lawrence County, the Ewing limestone is a gray rock in a single layer about ${ }_{5} 5$ inches thick. An outcrop on the Alfred Ward farm, near Getaway, was found 5 I feet above the Cambridge limestone. In many places to the north there is only red clay with nodular limestone in this horizon, or frequently sandstone. In some localities the limestone is so ferruginous that it has been dug for iron ore.

"A reptilian bone is reported from the same limestone in Harrison County, in a railroad cut about I mile west of the village of Jewett."

It is evident, from the descriptions given by Dr. Condit of the Conemaugh formation in Ohio, that the conditions there near the close of Carboniferous were in many regards very similar to those of the western deposits and that animal life there would have existed amidst almost identical surroundings. This fact is further emphasized by the similarity in the shading of the limestones into sandstones, as described by Condit: ${ }^{\mathrm{b}}$

"The sudden thinning of the non-marine limestones to the southward along the Ohio outcrop is noteworthy. Both the Conemaugh and the Monongahela have

\footnotetext{
- Condit, Bull. No. 17, Geol. Surv. Ohio, p. 37.

b Condit, Ibid., p. 250.
} 
numerous non-fossiliferous limestone beds southward as far as Athens County, but beyond that nearly all fail to appear, and in the same area there is a sudden increase in the amount of red beds, thus forming an almost continuous series from the Conemaugh through the Monongahela uniting with those of the Dunkard."

On pages 250-260 Dr. Condit gives an account of the deposits of the Conemaugh formation which might be applied without change to many places in the western Red Beds. He concludes that the beds were deposited in lagoons or on deltas in a region with a rather arid climate which was occasionally flooded by shallow and short-lived invasions of the sea. After comparing the beds with those of the Mauch Chunk as described by Barrel, he concludes:

"The Permian of the West, characterized by bright colors and beds of gypsum, is a still more striking illustration of this kind (beds deposited as deltas in a semiarid climate). While evidence of such pronounced aridity is lacking in the Permian (Dunkard) beds of the Appalachian basin, still it is evident that conditions were somewhat similar. It is believed that the appearance of the red color in the Conemaugh marks the beginning of the Permian. In southern Ohio, where the Monongahela coals and limestones are scantily developed, the red beds are practically continuous from the Conemaugh through the Monongahela, uniting with those of the Dunkard."

The author has examined a fragment sent to him by Dr. Bownocker and which is undoubtedly that of a fish. Unfortunately other fragments, upon which the presence of amphibians and reptiles were determined, have been lost.

PENNSYLVANIA AND WEST VIRGINIA.

Fossil vertebrates closely related to those of Texas have been found near Pittsburgh, Pennsylvania, in a shale just beneath the Ames limestone. The beds in which these fossils were found are described by Raymond, " the discoverer, as follows:

"The bones are from the upper part of the formation which I. C. White has named the Pittsburgh red shale (Geol. Survey West Virginia, vol. 2, p. 263). This formation is usually from Ioo to I 25 feet thick in the vicinity and consists of red clays and red and yellow sandstones. At the top there is a bed of almost structureless clay, which varies from 18 to 40 feet in thickness. At Pitcairn the clay is 37 feet thick, and the fossils were found 4 feet above the base of the clay. Three feet above the base of the clay there is a layer of nodular limestone, and the teeth were found lying on this layer where it projects from the bank on the roadside. The other bones were all imbedded in the clay about I foot above the limestone. On the Pittsburgh shale rests the Ames limestone, the youngest of the marine limestones in the region. It is almost exactly in the middle of the Conemaugh series. It is 3 I 5 feet below the base of the Pittsburgh coal, and 695 feet below the base of the Dunkard series (Permian). The Ames limestone is about 300 feet above the Freeport coal (top of the Allegheny series)."

The Pittsburgh red shale is described by White:

"As a rule the Friendsville coal, or, in its absence, the Ames limestone, rests directly upon a soft red or purple shale, which, from its fine exposure along the grade

"In Case, Annals Carnegie Mus., vol. IV, Nos. II and IV, p. 234, 1908.

b White, West Virginia Geol. Surv., vol. II, pp. 263, 264, 1903. 
lines of many railroads at Pittsburgh, has been named from that locality. Occasionally there is some limy gray or red shale under the overlying coal or limestone, as the case may be, and then comes another limestone bed quite different in color and texture, and only slightly fossiliferous. The limestone is found occasionally in Ohio, and has there been named the Ewing limestone by the Ohio geologists. It has been seen at Huntington and a few other localities in West Virginia, but does not appear to be very persistent. As a rule, the measures below the Ames limestone and Friendsville coal consist of deep red and variegated shales, often marly and containing nuggets of impure limestone and iron ore. The red beds extend from the Ames limestone downward from 50 to roo feet. Although red sediments may occur at any horizon in the Conemaugh series, between the Mahoning sandstone and the Pittsburgh coal, yet these near the middle of the series are the thickest, most persistent and striking of all. It is this band of Pittsburgh red shale, 30 to roo feet thick, which makes such a conspicuous belt of red soil entirely across the State, from the Pennsylvanian line at the north to the Kentucky border on the Big Sandy River."

It is interesting to note that above the Conemaugh in the Monongahela there is a change from limestone to red shale almost identical in character with that which occurs in the Texas and Oklahoma regions.

MONONGAHELA BEDS.

In the north half of the State the Monongahela is nearly half limestone, and no red shales.

"In passing southwest from Harrison, Taylor, and Lewis Counties, however," the limestones practically disappear, along with most of the coal beds, while red shales come in as the linnestones go out, apparently replacing the latter, and the sandstones grow more massive than in the northern area, thus giving origin to a rugged topography and less fertile soils.

"These rocks extend over a wide area along the Ohio River and for many miles south of it, as far as the Great Kanawha, and in a narrow belt from that point to the Big Sandy, where, in the center of the Appalachian trough, the lowest of these beds passes into the air before reaching the Kentucky line.

"No marine fossils have ever been discovered in any of the limestones of the Monongahela series, and everything indicates that the deposits are of fresh-water origin. The black slates always contain fish remains in the shape of scales and teeth, but nothing is known of their affinities, because they have never been studied. The water may have been estuarine and slightly brackish, but the minute Cyprian and Estherian-like forms whose skeletons, mostly broken and pulverized, make up the principal mass of the Monongahela series, testify clearly against their marine origin."

With regard to the significance of the Pittsburgh red shale and its vertebrate fossils, it is well to quote Dr. I. C. White, ${ }^{b}$ who remarks:

"Viewed from the standpoint of change in physical conditions the proper place for such dividing plane between the Conemaugh and Allegheny beds would be the first general appearance of red rocks, near the horizon of the Bakerstown coal, about roo feet under the Ames or crinoidal limestone horizon. That a great physical change took place soon after the deposition of the Mahoning sandstone rocks, the

a White, West Virginia Geol. Surv., vol. II, pp. I24, I25, I903.

b White, West Virginia Geol. Surv., vol. II, p. 226, 1903. 
present basal members of the Conemaugh series, must be conceded, since no red beds whatever are found from the base of the Pottsville up to the top of the Allegheny, and none worth considering until after the epoch of the Upper Mahoning sandstone.

"The sudden appearance or disappearance of red sediments after their absence from a great thickness of strata is always accompanied by a great change in life forms, and the present one is no exception. In fact, the invasion of red sediments succeeding the Mahoning sandstone epoch of the Conemaugh may well be considered as the 'beginning of the end' of the true Coal Measures, both from a lithological as well as a biological standpoint, and hence it is possible that the best classification, aside from the convenience of the geologist, would leave the Mahoning sandstone in the Coal Measures, and place the rest of the Conemaugh, as well as the Monongahela series above, in the Permo-Carboniferous. This reference is also confirmed by the character of the fauna and flora, both of which contain many forms that characterize the Permo-Carboniferous beds of Kansas and the West, as may be seen in the lists published on a subsequent page under the detailed description of the principal Conemaugh strata."

\section{PRINCE EDWARD ISLAND AND NOVA SCOTIA.}

The age of the red rocks in Prince Edward Island, adjoining portions of Nova Scotia and New Brunswick, was, by error in the interpretation of the fossil reptile Bathygnathus, by Cope, fixed as Triassic. They are now definitely known to be Permian or Permo-Carboniferous. Russell a has summarized the evidence for the Triassic age of the beds in Prince Edward Island, and has shown that there is no reason to believe Triassic to be present:

"Conclusions. - The absence of Newark fossils in the rocks of Prince Edward Island; the close lithological similarity of the beds in the upper and lower portions of the sections there exposed, the lower rocks being Permo-Carboniferous; and the lithological difference of the rocks from the sandstone and shales of the Newark system, seem to be sufficient ground for not considering any portion of the stratified rocks of Prince Edward Island as belonging to the Newark system."

Huene $^{\mathrm{b}}$ and Case $^{\mathrm{c}}$ have shown that Bathygnathus borealis is a PermoCarboniferous reptile closely related to Dimetrodon.

Matthews ${ }^{d}$ has given the following account of the deposits in Prince Edward Island, which shows clearly the similarity in the conditions of deposition to those which prevailed during the formation of the Red Beds in western North America:

"GEOLOGICAL CYCLES IN MARITIME PROVINCES.

"Carboniferous Cycle.

“*** The millstone grit is essentially a part of the Coal Measures, but by the greater prevalence of red sandstones and shales shows a relation in its climate and conditions to the underlying Lower Carboniferous series.

- Russell, U. S. Geol. Survey Bull. No. 85. Correlation Papers-The Newark System, chap. III, p. 25.

b Huene, Neues Jahrb. für G. M. u. P., Beilage Bd., 1905, pp. 321-353.

- Case, Science, n. s., vol. Xxir, Ig05, p. 52.

d Matthews, Roy. Soc. Canada, Proc. and Trans., vol. II, sec. IV, p. I2 I, 1908. 
"Permian Subcycle.

"The rocks of this period *** are largely spread in Prince Edward Island. Much of the phenomena of this time are beyond our observation, as the sediments of the period are, to a great extent, concealed beneath the waters of the Gulf of St. Lawrence.

"The terrane begins with a conglomerate well shown near Pictou, in Nova Scotia, and extending thence along the northern shores of Nova Scotia into New Brunswick. Mr. Fletcher's account ${ }^{\mathrm{a}}$ of the strata of this terrane recalls in many respects the conditions and aspect of the Upper Devonian rocks of this region. The great preponderance of red shales and red sandstones, the prevalence of plant remains in many beds, the occasional presence of nodular or 'botryoid' limestones, all suggest deposits which may have been laid down in a comparatively dry climate. * * * They suggest that the Carboniferous plain *** was now reduced in area to a tract including the present southern shallows of the Gulf of St. Lawrence *** on this extended plain, with rivers entering it from the west and south, would have been spread out the red sands and muds which now form the bulk of the Permian deposits of Acadia."

In his description of the Triassic cycle, in the region around the Bay of Fundy, Matthews, after describing the prevalence of volcanic activity, divides the sediments into three groups:

The lowest is composed of "bright red sandstones with a cement more or less calcareous, well laminated, and often showing oblique lamination." “* * * A drier and probably colder climate" prevailed at this time.

The second group shows a "sudden transition to coarse pebbles," such as those of a shingle beach, "often without a matrix," except by secondary infiltration.

The third group is made up of sandstones and shales, mostly reddishbrown, with some gray sandstones.

This last cycle may be Jura-Triassic. There are no data yet for determining the exact time limit.

aletcher, Can. Geol. Surv., vol. 5, n. S., part 2, rep. P., p. ro8. 


\section{CHAPTER V.}

\section{GEOGRAPHY OF NORTH AMERICA AT THE CLOSE OF PERMO- CARBONIFEROUS.}

The surface of the United States east of Ozarkia was largely free from an epicontinental sea in the closing period of the Paleozoic. Schuchert, ${ }^{a}$ in his chart of the submergences, shows a decided retreat of the sea, beginning at the close of the Pottsville and continued until the close of the Upper Permian, when it was at its maximum. In his chart of formations, opposite page 556, he shows Permo-Carboniferous deposits in the bituminous region of Pennsylvania, the northern Appalachian region, Ohio, Kansas, Iowa, Oklahoma, and central and trans-Pecos Texas.

Ulrich, in his Revision of the Paleozoic System, page 343, shows an elevation at the close of the Pennsylvanian and a withdrawal of the Gulf invasion which formed the Permo-Carboniferous limestones of eastern Kansas, Oklahoma, and Nebraska. It is well recognized that in a general way the withdrawal of the seas of upper Pennsylvanian time was by a gradual uplift in the northeast which forced the waters toward the southwest, until the last stand was made in the Texas-Oklahoma-Kansas region within the limits of the Wreford and equivalent limestones. ${ }^{b}$ On the west this sea was bordered by the great flat, generally dry but with many pools, some of large size, crossed or watered by streams and subject to short-lived inundations of ocean water in the southwest (Clear Fork limestones). The border between the sea and the flat can only be indicated very broadly, and probably never was a stable line; slight changes in level induced wide advances and retreats of the strand lime. Broadly speaking, the border was where the limestones shade into red deposits toward the west, as indicated above (p. I2). On the northern part of the flat rose the precursors of the Arbuckle Hills, and farther to the west those of the Wichita Mountains, at that time masses of considerable magnitude.

Gordon ${ }^{*}$ has given the following account of the sedimentation on this flat in Texas, which is equally applicable to the beds in Oklahoma:

"Conditions of Sedimentation.-The character of the sedimentation and the contents of the strata in the 'Red Beds' area suggest that the region was a tidal flat or a low, swampy area subject to overflow and adjoining the open area which lay toward the south and west. This view is maintained by Case, who states that 'the whole formation seems to be very clearly the result of deposition, either in the form of a wide delta or in very shallow water.' He adds, further, that 'the remains which

a Schuchert, Palcogeography of North America, chart of submergences and emergences and map of Lower Permian.

b Girty, Outlines of Geological History, chap. vr, pp. 126, 127.

- Gordon, U. S. Geological Survey, Water Supply and Irrigation Paper No. 317, pp. 26, 27, 1913. 88 


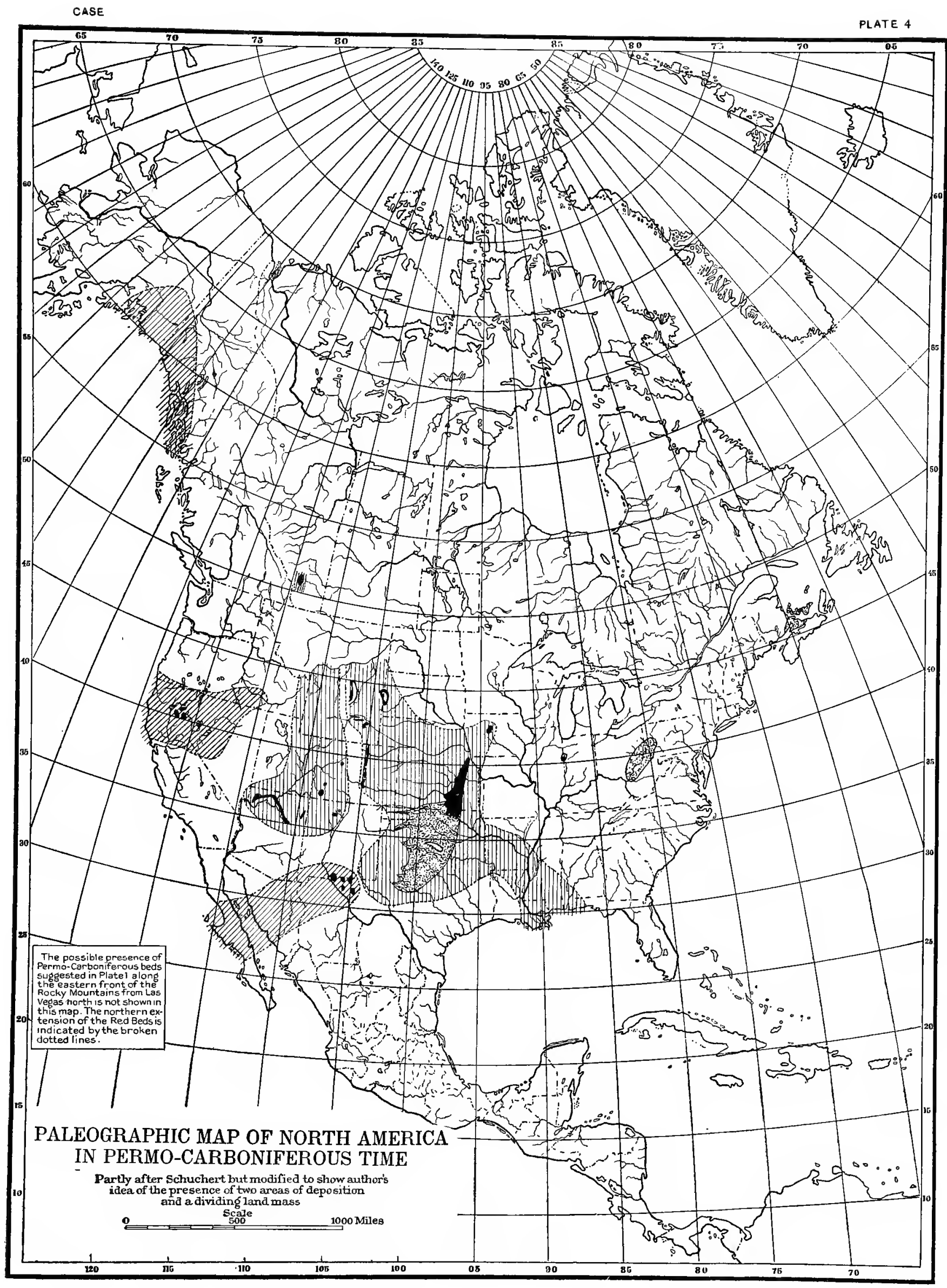



are found on or in the sand layers were evidently washed there by currents from a distant shore, and they are generally more or less imperfect, having been dispersed by the action of the current or by predatory animals, while those found in clay were evidently animals which mired down on wide mud flats or were drifted out on the surface of the stagnant lagoons.'

"The clays and the sandstones are separated in some places by unconformities which are considered by Case to be the result of currents that eroded channels in the clay in which the sands were afterward deposited. They do not represent apparently any considerable time interval between the two deposits. Moreover, the conglomerates containing concretions of ferruginous clay are evidently additional indications of transitory currents in an ordinarily quiet lagoon or over the tidal flats of a wide delta.

"The red sediments evidently had their source in the degradation of the Wichita Mountains, which lie directly to the north of this region, in Oklahoma. These mountains were uplifted during or at the close of the Pennsylvanian epoch and are now, together with their acco npanying elevations on the east, the Arbuckle Mountains, partly buried in the sediments they have furnished.

"The fact that in this region, as shown by their outcrop toward the east and by the strata penetrated in deep wells, the upper beds of the Cisco formation consist of sediments corresponding in character to those of the Wichita formation, suggests that mud flats may have characterized the closing stages of the Pennsylvanian epoch in this region.

"Thickness.- In Shackelford County the thickness of the Wichita formation is estimated to be I,000 to I,200 feet. Two-thirds or more of the formation consists of blue clays and shales. Farther south, in the vicinity of Colorado River, limestones constitute the major part of the formation. To the north from Shackelford County the calcareous sediments diminish, and before reaching the Oklahoma border they practically disappear. No reliable estimate can be made of the thickness of the formation in this part of the region, though it is probably not less than I,500 feet."

South of the north line of Oklahoma the Permo-Carboniferous beds disappear beneath the Triassic at the eastern side of the Staked Plains (plate 13 , fig. I). On the western side of the Staked Plains Permo-Carboniferous beds appear in the valley of the Pecos River, according to Beede (see p. 58), but they are absent in the latitude of Tucumcari, Montoya, and Las Vegas. Apparently the condition of river and delta deposits extended across the Staked Plains and west to the Rocky Mountains south of this latitude as it did to the north, but here there is no certainty that it reached to the mountains.

As outlined above (pp. 62-7I), the Red Beds of Permo-Carboniferous age in the northern part of the Plains Province shade into limestones toward the east and north, indicating the western edge of the open-sea waters. There seems little doubt that the northern Red Beds are connected with those in the south beneath the later deposits, and that both are parts of one great area of deposition.

Beyond the Rocky Mountains red bed conditions prevailed along the Chama River in Rio Arriba County, New Mexico, and probably much farther to the north and south, though this may have been in a slightly earlier time. 
The deposits of Rio Arriba County certainly extend west under the Cretaceous and Tertiary of northwestern New Mexico into Arizona, where they reappear as the Moencopie and Kanab (?). Permian or Permo-Carboniferous invertebrate fossils have been found in limestones in northern Utah and as far north as the Bighorn Mountains. The limestones are apparently connected with the Red Beds of New Mexico and Arizona in somewhat the same way as the limestones of the Plains Province are connected with the Red Beds there. It is possible, even probable, that the deposits of the Basin Province were formed somewhat earlier than those of the Plains Province, but both were laid down within the limits of the Permo-Carboniferous.

I am inclined to suggest some changes in Schuchert's paleogeographic map of the lower Permian (Permo-Carboniferous). It is increasingly evident from a study of the Red Beds that there was a land-mass of great size and height between the two areas of land deposits on the eastern and western sides of the Rocky Mountains. No attempt has been made in the present paper to determine the amount of material included in the portion of the Red Beds considered as Permo-Carboniferous in age, but the briefest inspection reveals an amount of material so great that it can have originated only in the degradation of a mass of land far larger than the present igneous and early Paleozoic rocks in the Rocky Mountains, and if we add to the PermoCarboniferous deposits those of Pennsylvanian, Triassic, and Jurassic age which are with difficulty distinguished or are evidently the result of a continuation of similar conditions, the mass of the land later degraded assumes majestic proportions, for it is easily demonstrable that the source of by far the largest proportion of the Red Beds material was the land-mass on the present site of the Rocky Mountains.

In the Plains Province the conditions for land deposition shaded into limestone-forming seas to the east and northeast; that these seas were narrow from east to west there can be no doubt, because of the high land of Ozarkia and the land deposits in Iowa, which show an elevation, but they were sufficiently broad to prevent the transportation of any material from the eastern land to the flats where the Red Beds were formed.

The outline of the Red Beds west of the Rocky Mountains is not yet clearly made out, but the land deposits are more closely associated with limestones both vertically and horizontally, indicating shorter duration and lesser extent, with a closer approximation of the ocean waters to the great land-mass than in the east.

The Wichita Mountains and the Arbuckle Hills were only subsidiary sources of supply. It is probable that much of the material of the Red Beds in Arizona came from sources not yet clearly imagined; however, there is evidence that the Rico was deposited near the source of the material, and the distance from Ouray to the Grand Canyon is not greater than from the Front Ranges of the Rockies to some localities of Red Beds in Kansas. 
The two provinces of Red Beds as outlined in this paper can only be considered as great flood-plains or deltas (in Barrel's broad interpretation of that word).

East of the Permian limestones of Texas, Oklahoma, Kansas, and Nebraska the surface of North America was probably very largely out of water; the few evidences of river channels, local pools, etc., are sufficiently meager, but by their very meagerness indicate the large extent of land surface. Had there been deposits of any extent from marine or fresh waters some traces would have undoubtedly remained to us, for the eastern half of the Mississippi Valley has been a region of comparatively slight degradation since the close of the Paleozoic. 


\section{CHAPTER VI.}

\section{AGE OF THE RED BEDS.}

The age of the Red Beds north of Oklahoma, in Kansas, was long in doubt, due to the absence of fossils. At first considered as Carboniferous, or Permian, by the earliest writers, they were later referred to the Cretaceous, and finally to the Triassic and Upper Permian. The history of the various discussions of the age of these beds has been summarized by Cragin ${ }^{a}$ and Prosser, ${ }^{\mathrm{b}}$ and need not be reviewed here. The final conclusion of those who have worked latest upon the Kansas beds is that they are of the same age as the Texas-Oklahoma beds, i.e., Permian or Permo-Carboniferous. This conclusion has been reached because of the more or less complete tracing of the beds into Oklahoma and even Texas, and the finding of Permo-Carboniferous fossils in the Red Beds of Kansas.

With regard to the Texas Red Beds the opinion is less consistent. Cope, and, following him, later writers, considered the vertebrate fauna as indicating the Permian age of the beds. Case, ${ }^{c}$ in 1908 , reported on the fossils found in Upper Pennsylvanian beds of Pennsylvania, and this led him to a reconsideration of the value of the evidence of the vertebrate fauna of Texas for the Permian age of the Red Beds. His results were purely negative, ${ }^{\mathrm{d}}$ but a single genus common to America and Europe being restricted to the Permian of Europe. Later he discovered Spirifer rockymontana above beds carrying Permo-Carboniferous vertebrates in New Mexico. This is a Pennsylvanian form not occurring above that horizon (Schuchert) and perhaps limited to the Allegheny (Girty, letter to the author). These facts have led Williston and Case ${ }^{c}$ to the conclusion that the vertebrate beds of Texas, Oklahoma, and New Mexico are to be considered on the border-line between the Permian and Carboniferous.

Taff ${ }^{f}$ places the Permian (sic) of Texas above the Cisco. "This group (the Albany) is succeeded by the Permian, which overlaps upon the Cisco division between the Brazos and the Red River."

Udden ${ }^{\text {g }}$ says the Wichita "rests on the Cisco." And again, page 3I: "Evidently the geographic conditions prevailing during the deposition of the Wichita beds were different from those existing during the making of the Cisco."

a Cragin, Colorado College Studies, vol. vi, pp. 2 and 396.

b Prosser, Kansas University Geological Survey, vol. II, pp. 55 and 97, 1897.

- Case, Ann. Carnegic Mus., vol. Iv, Nos. 3 and 4, pp. 23 and 4 I.

d Case, Jour. Gcol., vol. I6, No. 6, pp. 572-580, 1908.

- Williston and Case, Jour. Geol., vol. Xx, No. 1, pp. I-I2, I9I2.

'Taff, 22 Ann. Rpt. U. S. Geological Survey, part 3, p. 402, 1902.

B Udden, Bull. University of Texas No. 246, p. I, I9 I2. 
Gordon " says the Cisco is not the same as the Wichita and speaks of the separation between them.

David White ${ }^{b}$ is convinced from paleobotanical evidence that the Texas beds are Lower Permian. After giving floral lists from Texas, Oklahoma, and Kansas and pointing out their strong Permian content, he says:

"The very incomplete collections of fossil plants from the Wichita formation in Texas, from its supposedly approximate equivalents in Oklahoma, from the Chase and Sumner groups in Kansas, and from the great series of undifferentiated 'Red Beds' in the Rocky Mountain region of southern Colorado, showed a mixed flora embracing: (I) mainly representatives of the Permian flora of western Europe, and including many types not previously known in North America; (2) a smaller portion peculiar to the Gigantopteris association in south-central and southwestern China; and (3) several types apparently identical with, or very close to, forms hitherto known only in the Permian or the Uralian region.

"The distribution of the floral elements indicates that the western European, or cosmopolitan, elements of the flora migrated between North America and Europe, presumably by the same general northeastern route as that followed by their Pennsylvanian predecessors, while the distinctly Chinese types must have come to Texas and Oklahoma by the north Pacific (Alaskan) route, by which the related Uralian forms may also have migrated. Since the land migration of the Chinese types could hardly have been accomplished without the aid of essential continuity of environmental conditions, and since it is probable that the Gigantopteris elements lived under climatic conditions mainly similar in both Texas and China, the conclusion appears justified that the climatic province under which they thrived in Asia extended to western North America, and that it included the region of north Pacific migration. The mingling of western European species with Gigantopteris in the southwestern 'Red Beds' is construed to indicate that this region was probably on the eastern border of the Gigantopteris province."

Beede says" "the Permian age of the beds (in Oklahoma) has been pretty well confirmed."

\section{LIMITING HORIZONS OF THE VERTEBRATE FAUNA.}

The author of this paper has no intention of making any effort to determine exactly the horizon of the vertebrates here called Permo-Carboniferous. The exact valuation of these beds must be accomplished by the workers in invertebrate paleontology, aided by detailed comparison of the American vertebrates with those of the rest of the world, which would be quite beyond the limits of this work and must be reserved for future papers.

Prosser, Beede, Girty, Gould, Schuchert, and others have attempted to determine the horizon of the beds from invertebrate fossils and have not reached concordant results. All that is attempted here is to locate in accepted terms the upper and lower limits of the beds which represent the time of the vertebrate fauna here discussed. For this purpose the lower limit of the Permo-Carboniferous beds is tentatively drawn at the base of the

- Gordon, with Girty and White, Jour. Geol., vol. XIX, No. 2, pp. II9, I20, I9I I.

b White, Proc. U. S. Nat. Mus., vol. 4I, p. 5I3, IgI2.

- Beede, Oklahoma Geological Survey, Bu1l. 2 r, p. 37, 19 I4. 
Wreford limestone, Kansas (Beede ${ }^{\text {a }}$ in a recent paper draws it at the base of the Neva limestone); Enid, Oklahoma; Wichita, Texas; Manzano (?), New Mexico; Moencopie and Kanab (Aubrey), Arizona; Cutler and Lykins, Colorado; Upper Weber, Utah; Upper Embar and Opechee, Wyoming; Opechee, South Dakota; Merom sandstone, Indiana; Ames limestone, Pennsylvania. The charts opposite pages 64 and 66 (plates 2 and 3) from Darton show the relations of most of the Red Beds in the northern part of the Plains Province.

The lower limit of the fauna is confessedly vague and shadowy, passing far down into the Pennsylvanian. The Pennsylvanian amphibians described by Moodie in numerous papers are so close to those occurring in association with the Permo-Carboniferous forms from Texas that it is evidently a case of overlapping, and the only recognizable line is that where the first reptile occurs. It is, of course, probable that the reptiles occurred at lower horizons. In I9Io Moodie found a form near Cricotus in the Mazon Creek shales. ${ }^{\text {b }}$ These shales are near the base of the Allegheny (or even the top of Pottsville). David White regards them as equivalents of Coal No. 2 of Illinois (Morris and Braidwood coals of the Clarion). They are all regarded by him as having close relationship with the Cherokee of Henry County, Missouri, at the base of the Allegheny. ${ }^{c}$

The Linton coal, from which comes Eosauravus copei Williston (Isodectes punctulatus, originally Tuditanus punctulatus, Cope), belongs in the Upper Freeport coal (Coal No. 6), and is referred by Prosser ${ }^{\text {d }}$ to a position near the top of the Allegheny. The old coal mine (Diamond coal mine) located near Linton, Jefferson County, Ohio, from which numerous amphibians and a few reptiles have been collected, has been abandoned, and further collections are impossible. Williston ${ }^{\mathrm{e}}$ and Moodie ${ }^{\mathrm{f}}$ have described the genus Eosauravus, giving figures, and demonstrated its reptilian nature.

The earliest amphibians definitely comparable to the Texas fauna are those from the Pittsburgh red shale of Pennsylvania. The Pittsburgh red shale lies 300 feet above the Freeport and 695 or more feet below the base of the Dunkard. Dr. I. C. White ${ }^{\mathrm{g}}$ has remarked upon the significance of a red formation above the limestone, in describing the dividing-line between the Conemaugh and the Allegheny, which has been placed at the Upper Freeport coal. He says:

"Viewed from the standpoint of physical conditions, the proper place for such a dividing plane between the Conemaugh and the Allegheny beds would be the first appearance of red rocks near the horizon of the Bakerstown coal, about roo feet under the Ames or crinoidal limestone horizon. That a great physical change took place soon after the deposition of the Mahoning sandstone rock, the present basal

\footnotetext{
a Beede, Oklahoma Geol. Surv., Bull. 2 I, I9I4.

${ }^{b}$ Moodie, Sc., vol. 30, I9Io, p. 233.

' White, Bull. 2 I I, U. S. Geological Survey, p. I I I.

d Prosser, Jour. Geol., vol. XI, p. 5 I 9 et seq.

- Williston, Jour. Geol., vol. XVI, No. 5, I908, pp. 395-400.

${ }^{1}$ Moodic, Proc. U. S. Nat. Mus., vol, 37, p. I I, 1909.

g White, West Virginia Geol. Survey, vol. II, p. 226, 1903.
} 
member of the Conemaugh series, must be conceded, since no red beds whatever are found from the base of the Pottsville up to the top of the Allegheny, and none worth considering until after the epoch of the Upper Mahoning sandstone.

"The sudden appearance or disappearance of red sediments after their absence from a great thickness of strata is always accompanied by a great change in forms, and the present one is no exception. In fact, the invasion of the red sediments succeeding the Mahoning sandstone epoch of the Conemaugh may well be considered as the 'beginning of the end' of the true Coal Measures, both from a lithological as well as a biological standpoint, and hence it is possible that the best classification, aside from the convenience of the geologist, would leave the Mahoning sandstone in the Coal Measures, and place the rest of the Conemaugh, as well as the Monongahela series above, in the Permo-Carboniferous. This reference is also confirmed by the character of the fauna and flora, both of which contain many forms that characterize the Permo-Carboniferous beds of Kansas and the West, as may be seen in the lists published on a subsequent page under the detailed description of the principal Conemaugh strata."

If this sudden change has the significance attributed to it by White, we are justified in regarding the appearance of the forms beneath the Ames limestone as marking the advent of a new fauna, by evolution or migration, which apparently spread over the whole of North America, as evidenced by its discovery in localities from Prince Edward Island to New Mexico. This fauna, so far as we know, appeared at an earlier date in the eastern part of North America than in the western, suggesting the general route of immigration or spreading from its point of inception.

The red shale scries mentioned by White ${ }^{a}$ is the equivalent of the Pittsburgh Red Shale. The Ames limestone lies just above it. This last is "almost exactly the middle of the Conemaugh series, 3 I 5 feet below the base of the Pittsburgh coal, and 695 feet below the base of the Dunkard series (Permian). The Ames limestone is about 300 feet above the Freeport coal (top of the Allegheny series)." (Statement in a letter from Dr. Raymond.) It is eviderit, then, that the lower horizon of the reptiles is carried at least into the Allegheny at Linton.

The exact age of the beds in Illinois and Prince Edward Island, in which similar forms occur, is not yet determined.

The limit recognized for the Permo-Carboniferous fauna is, then, from the Pittsburgh Red Shales to the top of the Clear Fork. The stratigraphic extent of the space delimited it is impossible to state, as there is no direct correlation of the eastern and western beds possible, but it may be roughly stated as from the middle of the Conemaugh to near the top of the PermoCarboniferous. The limits of the fauna in America, however, are not those of Europe; the fauna was there continued into the Triassic.

a White, Geol. Surv. West Virginia, vol. II, p. 263. 


\section{PERMO-CARBONIFEROUS VERTEBRATE FAUNA NOW KNOWN.}

Table I classifies the Permo-Carboniferous fauna as now known, with their geographical and geological distribution.

TABLE I.

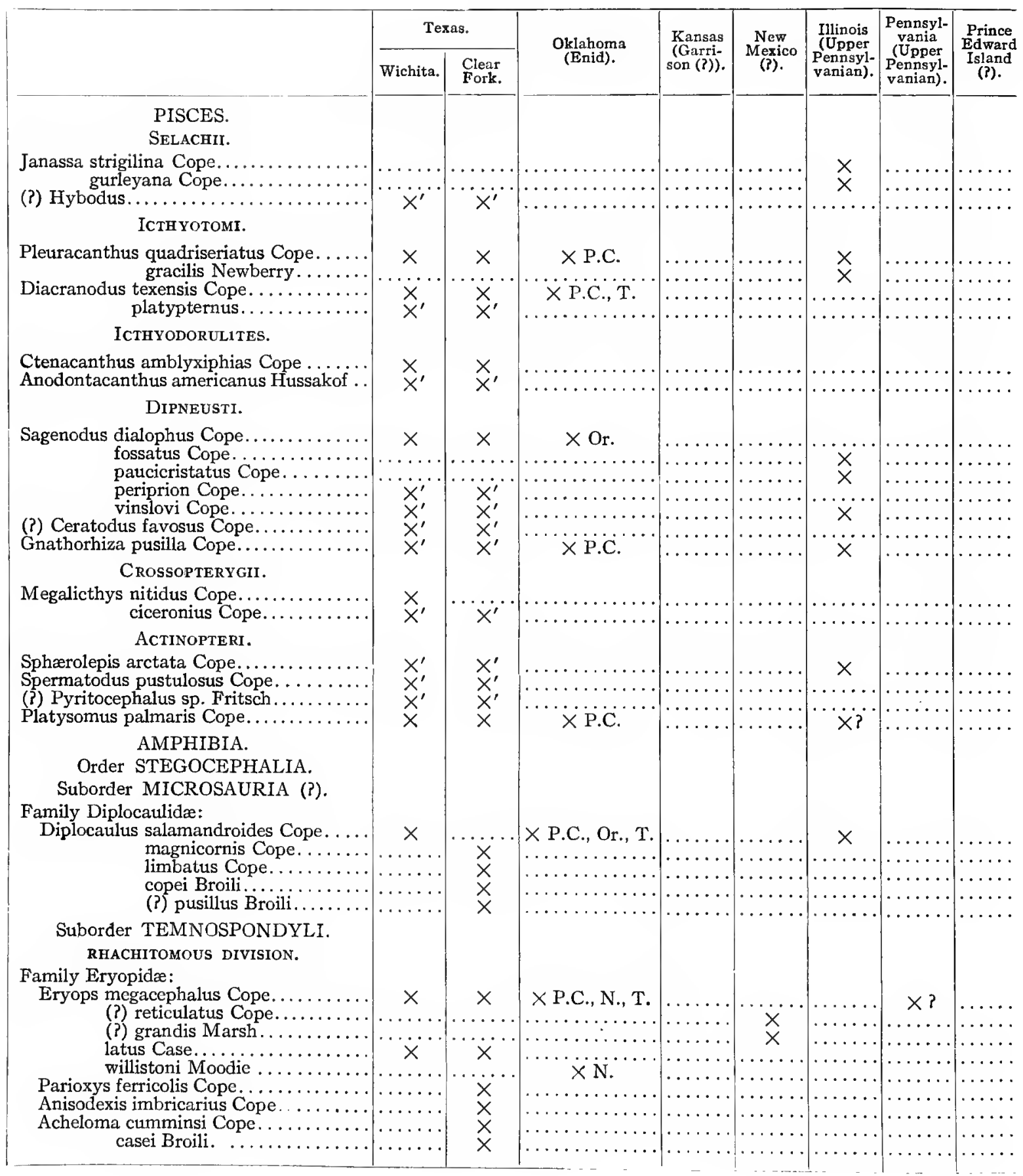


Table I.-Conlinued.

\begin{tabular}{|c|c|c|c|c|c|c|c|c|}
\hline & \multicolumn{2}{|c|}{ Texas. } & \multirow{2}{*}{$\begin{array}{l}\text { Oklahoma } \\
\text { (Enid). }\end{array}$} & \multirow{2}{*}{$\begin{array}{c}\text { Kansas } \\
\text { (Garri- } \\
\text { son (?)). }\end{array}$} & \multirow{2}{*}{$\begin{array}{l}\text { New } \\
\text { Mexico } \\
(?) .\end{array}$} & \multirow{2}{*}{$\begin{array}{c}\text { Illinois } \\
\text { (Upper } \\
\text { Pennsyl- } \\
\text { vanian). }\end{array}$} & \multirow{2}{*}{$\begin{array}{c}\text { Pennsyl- } \\
\text { vania } \\
\text { (Upper } \\
\text { Pentisyl- } \\
\text { vanian). }\end{array}$} & \multirow{2}{*}{$\begin{array}{c}\text { Prince } \\
\text { Edward } \\
\text { Island } \\
\text { (?). }\end{array}$} \\
\hline & Wichita. & $\begin{array}{l}\text { Clear } \\
\text { Fork. }\end{array}$ & & & & & & \\
\hline \multicolumn{9}{|l|}{ AMPHIBIA-Continued. } \\
\hline \multicolumn{9}{|l|}{$\begin{array}{l}\text { Family Trimerorhachidæ: } \\
\text { Trimerorhachis insignis Cope. }\end{array}$} \\
\hline bilobatus Cope... & $\hat{x}$ & & & . & & & & $\cdots \cdots$ \\
\hline $\begin{array}{l}\text { conangulus Cope...... } \\
\text { leptorhynchus Case.... }\end{array}$ & & $x$ & & & & & & $\ldots \ldots$ \\
\hline $\begin{array}{l}\text { leptorhynchts } \\
\text { mesops Cope. }\end{array}$ & $\ldots \ldots$ & & $\times \mathrm{N}$ & & & & $\cdots$ & $\cdots \cdots$ \\
\hline $\begin{array}{l}\text { mesops Cope } \\
\text { alleni Case. }\end{array}$ & & $\vec{x}$ & & & & & $\cdots \cdots$ & $\cdots \cdots$ \\
\hline Zatrachys serratus Cope.. & $x$ & & & & & & $\cdots \cdots$ & $\cdots \cdots$ \\
\hline $\begin{array}{l}\text { conchigerus Cope } \\
\text { Tersomius texensis Case }\end{array}$ & & $x$ & . & $\cdots$ & & . & $\cdots$ & $\cdots \cdots$ \\
\hline $\begin{array}{l}\text { Tersomius texensis Case....... } \\
\text { Family Dissorhophidæ: }\end{array}$ & \multirow{2}{*}{\multicolumn{8}{|c|}{$\begin{array}{l}\text { Tersomius texensis Case......... } \\
\text { Family Dissorhophidæ: }\end{array}$}} \\
\hline \multirow{2}{*}{\multicolumn{9}{|c|}{$\begin{array}{l}\text { Dissorhophus multicinctus Cope. . . . . } \\
\text { Alegeinosaurus aphthitos Case. . . }\end{array}$}} \\
\hline & & & & & & & & \\
\hline $\begin{array}{l}\text { Cacops aspidephorous } \\
\text { Family Aspidosauridæ: }\end{array}$ & & $x$ & & & & & & \\
\hline \multirow{2}{*}{\multicolumn{9}{|c|}{$\begin{array}{r}\text { Aspidosaurus chiton Broili... } \\
\text { glascocki Case. }\end{array}$}} \\
\hline & & & & & & & & \\
\hline apicalis Cope & & & & & $x$ & & ‥ & … \\
\hline $\begin{array}{l}\text { crucifer Case. . } \\
\text { novomexicanus }\end{array}$ & $x^{\prime}$ & $x^{\prime}$ & $\times \mathrm{T}$. & & & & & $\cdots \cdot$ \\
\hline $\begin{array}{c}\text { novomexicanus Williston } \\
\text { Broiliellus texensis Williston.......... }\end{array}$ & & $\ddot{x}$ & & & $x$ & & $\cdots \cdots$ & $\cdots \cdots$ \\
\hline $\begin{array}{r}\text { peltatus Williston.. } \\
\text {. }\end{array}$ & & $\hat{x}$ & & & & & & $\cdots$ \\
\hline \multicolumn{9}{|l|}{$\begin{array}{l}\text { peltatus Willistor } \\
\text { Family Trematopside: }\end{array}$} \\
\hline \multirow{2}{*}{\multicolumn{9}{|c|}{ Order URODELA. }} \\
\hline & & & & & & & & \\
\hline \multicolumn{9}{|l|}{ Suborder -} \\
\hline \multicolumn{9}{|l|}{$\begin{array}{l}\text { Family Lysorophida: } \\
\text { Lysorophus tricarinatt }\end{array}$} \\
\hline Lysorophus tricarinatus Co & $x$ & & & & & $x$ & . & $\cdots$ \\
\hline Suborder - & & & & & & & & \\
\hline $\begin{array}{l}\text { Family Crossotelidæ: } \\
\text { Crossotelos annulatus Case.. }\end{array}$ & & & $\times$ Or. & & & & & \\
\hline INCERT $Æ$ SEDIS. & & & & & & & & $\cdots$ \\
\hline Suborder GYMNARTHRIA. & & & & & & & & \\
\hline Family Gymnarthridæ: & & & & & & & & \\
\hline Gymnarth & & $x$ & & & & & . & $\cdots$ \\
\hline Cardiocephalus sternbergi Broil & & $x$ & & & & & $\cdots$ & $\cdots \cdots$ \\
\hline EMBOLOMEROUS DIVISION. & & & & & & & & \\
\hline Family Cricotidæ: & & & & & & & & \\
\hline Cricotus hypantricus Cope.... & $x$ & . & $\times$ Or., $T$ & $\times ?$ & & & & .. \\
\hline $\begin{array}{l}\text { gibson } \\
\text { hetero }\end{array}$ & & & & & & $\begin{array}{l}x \\
x\end{array}$ & $\cdots$ & $\cdots$ \\
\hline $\begin{array}{l}\text { heteroc } \\
\text { crassidi }\end{array}$ & $\ddot{x}$ & & & & & $\ldots \ldots$ & $\cdots \cdots$ & $\cdots \cdots$ \\
\hline Cricotillus brachy & $\ldots$ & & $\times$ Or. & & & & $\ldots \ldots$ & $\ldots \ldots$ \\
\hline Chenoprosopus milleri Mehl... & & & & & $x$ & & $\cdots \cdots \cdots$ & $\cdots \cdots$ \\
\hline Metamosaurus fossatus Cope.. & X & & & & 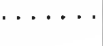 & $\cdots \cdots$ & ….. & $\cdots \cdots$ \\
\hline REPTILIA. & & & & & & & & \\
\hline $\begin{array}{c}\text { Order COTYLOSAURIA. } \\
\text { Suborder DIADECTOSAURIA. }\end{array}$ & & & & & & & & \\
\hline Family Diadectidæ: & & & & & & & & \\
\hline Diadectes sideropelicus Cope. . & $x$ & & & & & & $\cdots \cdots$ & .... \\
\hline phaseolinus Cope. & $x$ & $x$ & $\times \mathbf{T}$ & & & & $\ldots \ldots$ & $\cdots \cdots$ \\
\hline molari & $x$ & & & & & & ... & $\cdots \cdots$ \\
\hline biculminatus Cope......... & & $x$ & & & & $\cdots \cdots$ & $\cdots \cdots$ & $\cdots \cdots$ \\
\hline $\begin{array}{l}\text { fissus Cope. ................ } \\
\text { latibuccatus Cope......... }\end{array}$ & $\stackrel{x}{x}$ & $\cdots$ & $\cdots$ & & & & $\cdots$ & $\cdots \cdots$ \\
\hline (Nothodon) lentus Marsh........ & & & & & $\ddot{x}$ & & & \\
\hline maximus Case............... & $x^{\prime}$ & $X^{\prime}$ & X P.C. & & & & & $\ldots \ldots$ \\
\hline 1liston \& Case & & & & & $x$ & & & $\ldots \ldots$ \\
\hline Diasparactus zenos Case. & . & & & & $x$ & & & $\cdots \cdots$ \\
\hline Bolbodon tenuitectus Cop & & $x$ & & & & & & \\
\hline
\end{tabular}


TABle r.-Continued.

\begin{tabular}{|c|c|c|c|c|c|c|c|c|}
\hline & \multicolumn{2}{|c|}{ Texas. } & \multirow{2}{*}{$\begin{array}{l}\text { Oklahoma } \\
\text { (Enid). }\end{array}$} & \multirow{2}{*}{$\begin{array}{l}\text { Kansas } \\
\text { (Garri- } \\
\text { son(?)). }\end{array}$} & \multirow{2}{*}{$\begin{array}{c}\text { New } \\
\text { Mexico } \\
\text { (?). }\end{array}$} & \multirow{2}{*}{$\begin{array}{c}\text { Illinois } \\
\text { (Upper } \\
\text { Pennsyl- } \\
\text { vanian). }\end{array}$} & \multirow{2}{*}{$\begin{array}{c}\text { Pennsyl- } \\
\text { vania } \\
\text { (Upper } \\
\text { Pennsyl- } \\
\text { vanian). }\end{array}$} & \multirow{2}{*}{$\begin{array}{c}\text { Prince } \\
\text { Edward } \\
\text { Island } \\
(?) .\end{array}$} \\
\hline & Wichita. & $\begin{array}{l}\text { Clear } \\
\text { Fork. }\end{array}$ & & & & & & \\
\hline \multicolumn{9}{|l|}{ REPTILIA.-Continued. } \\
\hline \multicolumn{9}{|l|}{ Family Diadectidæ.-Continued. } \\
\hline Desmatodon hollandi Case.... & & & & & & & $\ddot{x}$ & $\cdots \cdots$ \\
\hline $\begin{array}{l}\text { Diadectoides cretin Case....... } \\
\text { Family Bolosauridæ: }\end{array}$ & & \multirow{2}{*}{\multicolumn{5}{|c|}{$\begin{array}{l}\text { Diadectoides cretin Case. ..... } \\
\text { Family Bolosauridæ: }\end{array}$}} & & $\ldots \ldots$ \\
\hline \multicolumn{4}{|l|}{$\begin{array}{l}\text { Family Bolosauridæ: } \\
\text { Bolosaurus striatus Cope...... }\end{array}$} & & & & & \\
\hline Ophideirus casei Broom... & $\hat{x}$ & & & $\cdots \cdots$ & $\cdots$ & $\cdots \cdots \cdots$ & $\cdots \cdots$ & $\cdots \cdots$ \\
\hline \multicolumn{9}{|l|}{ INCERT $Æ$ SEDIS. } \\
\hline $\begin{array}{l}\text { Bathyglyptus theodori Case........... } \\
\text { Chamasaurus dolichognathus Williston * }\end{array}$ & & $x$ & & .. & $x$ & & $\cdots$ & $\cdots$ \\
\hline \multicolumn{9}{|l|}{ Suborder PAREIASAURIA. } \\
\hline \multirow{2}{*}{\multicolumn{9}{|c|}{$\begin{array}{l}\text { Family Pariotichidæ: } \\
\text { Pariotichus brachyops Cop }\end{array}$}} \\
\hline \multirow{2}{*}{\multicolumn{9}{|c|}{$\begin{array}{l}\text { Pariotichus brachyops Cope. } \ldots \ldots \ldots \ldots \\
\text { Tomicosaurus sp. Case. } . . . \ldots \ldots \ldots\end{array}$}} \\
\hline & & & & & & & & \\
\hline \multicolumn{9}{|l|}{$\begin{array}{l}\text { Ectocynodon ordinatus Cope . . . . . . } \\
\text { Isodectes megalops Cope............ }\end{array}$} \\
\hline $\begin{array}{l}\text { Isodectes megalops Copc } \\
\text { Family Captorhinidæ: }\end{array}$ & & x & & & & & & $\cdots \cdots$ \\
\hline Captorhinus angusticeps Cope. . & & $x$ & $\times ?$, P.C. & & & & & \\
\hline aguti Cope.......... & & $x$ & & & & & & $\cdots \cdots$ \\
\hline s Cope............ & & $x$ & & & & & & $\ldots \ldots$ \\
\hline $\begin{array}{l}\text { 1llnoisensis } W \text { wlliston...... } \\
\text { aduncus Cope......... }\end{array}$ & & $\ddot{x}$ & & $\cdots$ & & $x$ & & $\cdots$ \\
\hline \multirow{2}{*}{\multicolumn{9}{|c|}{$\begin{array}{l}\text { aduncus Cope.... } \\
\text { Family Labidosauridæ: }\end{array}$}} \\
\hline $\begin{array}{l}\text { Labidosaurus hamatus Cope . } \\
\text { broilii Case.... }\end{array}$ & & $x$ & $\times$ P.C. & & & & & $\because$ \\
\hline \multirow{2}{*}{\multicolumn{9}{|c|}{$\begin{array}{l}\text { Family Limnoscelidæ: } \\
\quad \text { Limnoscelis paludis Williston. }\end{array}$}} \\
\hline Limnoscelis paludis Williston. & & & & & & & & \\
\hline \multicolumn{9}{|l|}{ Family Seymouriidæ: } \\
\hline $\begin{array}{l}\text { Seymouria baylorensis Broili.......... } \\
\text { Conodectes favosus Cope........... }\end{array}$ & & $\begin{array}{l}x \\
x\end{array}$ & X Or. & & & & & \\
\hline INCERT $Æ$ SEDIS. & & & & & & & & \\
\hline Helodectes isaaci Cope............. & $X^{\prime}$ & $x^{\prime}$ & - & $\ldots \ldots$ & ․ & & $\cdots$ & .... \\
\hline Pleuristion brachycoelus Case .......... & & $\begin{array}{l}X \\
\cdots\end{array}$ & $\times$ Or. & & & & & $\begin{array}{l}\cdots \\
\cdots\end{array}$ \\
\hline Archeria robinsoni Case........... & & $x$ & & & & & & \\
\hline Suborder PANTYLOSAURIA. & & & & & & & & \\
\hline $\begin{array}{r}\text { Pantylus cordatus Cope......... } \\
\text { brevispinatus Williston }\end{array}$ & & $\stackrel{x}{x}$ & & & & & $\cdots$ & $\ldots$ \\
\hline Order THEROMORA. & & & & & & & & \\
\hline Suborder PELYCOSAURIA. & & & & & & & & \\
\hline Family Poliosauridæ: & & & & & & & & \\
\hline Poliosaurus uniformis Cope..... & $x$ & & $\times$ P.C. & & & & & \\
\hline $\begin{array}{l}\text { Varanosaurus acutirostris Broili.. } \\
\text { Varanoops brevirostris Williston. }\end{array}$ & $\cdots$ & $\underset{x}{x}$ & . & & & & & . \\
\hline $\begin{array}{l}\text { Varanoops brevirostris Williston. } \\
\text { Poecilospondylus francisi Case.... }\end{array}$ & & $\begin{array}{l}x \\
x\end{array}$ & . & & & & & \\
\hline Theropleura retroversa Cope .... & $x$ & & & & & & & \\
\hline $\begin{array}{l}\text { grandis Case........ } \\
\text { ? Elcabrosaurus baldwini Case. }\end{array}$ & X & $x^{\prime}$ & & & & & & \\
\hline $\begin{array}{l}\text { ? Elcabrosaurus baldwini Case.. } \\
\text { Sphenacodon ferox Marsh...... }\end{array}$ & $\cdot$ & $\cdots$ & & $\cdots$ & $x$ & $\cdots \cdots \cdot \mid$ & . & - \\
\hline $\begin{array}{l}\text { Sphenacodon ferox Marsh. } \\
\text { Ophiacodon mirus Marsh. }\end{array}$ & & & & & $\frac{x}{x}$ & & & \\
\hline Scoliomus puercensis Williston \& Case. & 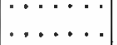 & 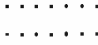 & 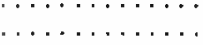 & $\cdots \cdots$ & $\hat{x}$ & $\cdots$ & $\cdot$ & $\begin{array}{ll}\cdots \cdots \\
\ldots \ldots\end{array}$ \\
\hline Family Clepsydropidæ:(Sphenacodontidæ) & & & & & & & & \\
\hline Clepsydrops natalis Cope............ & $x$ & $x$ & & $x$ & & $x$ & & \\
\hline Dimetrodon gigas Cope......... & $x^{\prime}$ & $x$ & X P.C. & $\cdots \cdots$ & $\cdots$ & & & \\
\hline $\begin{array}{l}\text { giganhomogenes Cope..... } \\
\text { incisivus Cope. . . . . . . . }\end{array}$ & $\ddot{x}$ & $\begin{array}{l}x \\
x\end{array}$ & 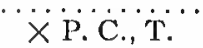 & $\ldots$ & & & & \\
\hline dollovianus Cope. & $x$ & $x$ & & & & & & \\
\hline
\end{tabular}

* In press. 
TABLE I.-Continued.

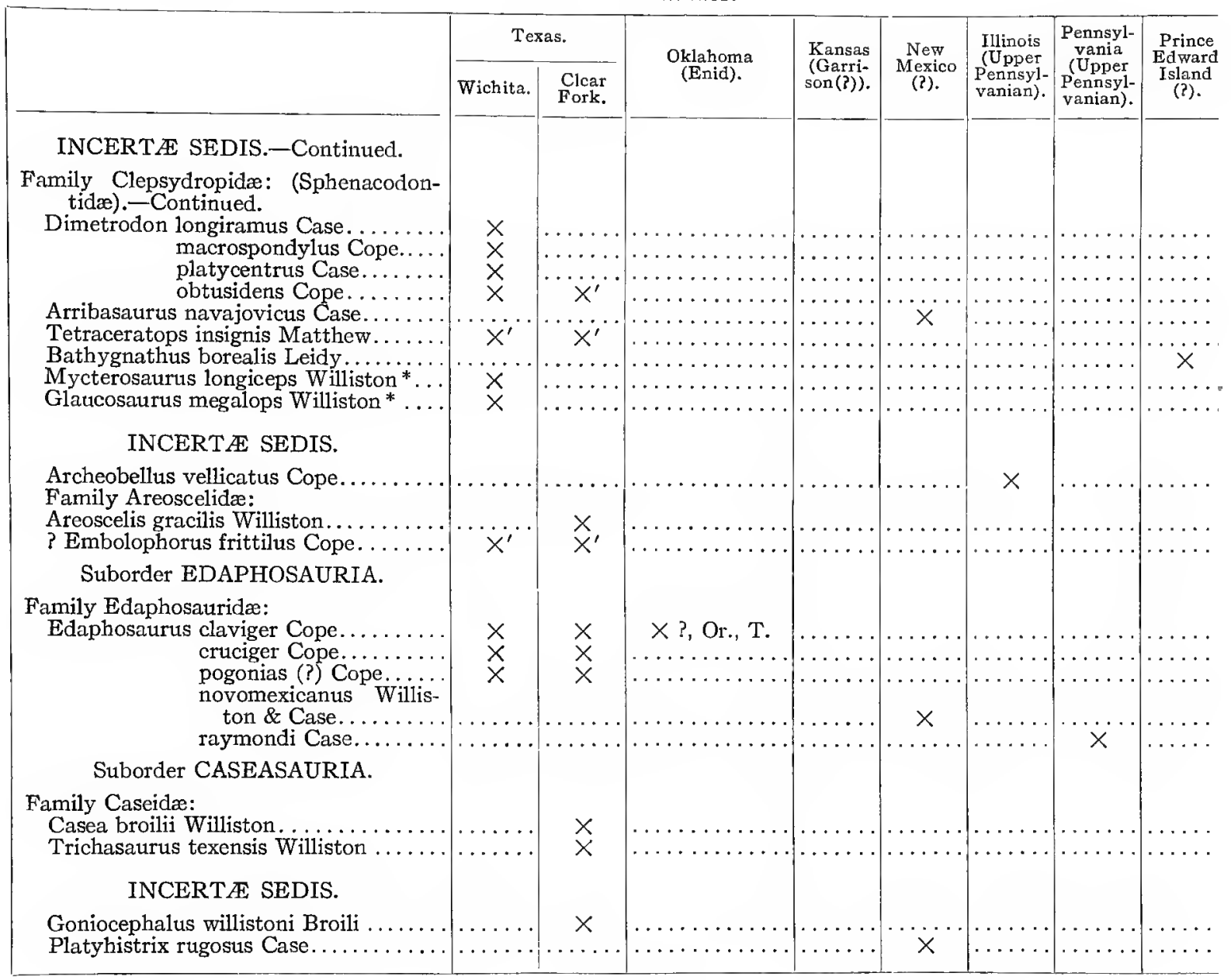

*In press.

Note.-A prime mark (') placed by an $X$ in this table indicates that it is possible that the specimen came from the formation indicated, but that the records are imperfect. Where such a mark is placed by the $X$ in both the Clear Fork and the Wichita it indicates that the specimen came from, possibly, both of the formations, but that the records are imperfect. P.C. = Pond Creek; Or. =Orlando; N. =Nardin; T. =Taylor ( 2 miles southwest); ? = species uncertain. 


\section{CHAPTER VII.}

\section{ANALYSIS OF THE FAUNA.}

In attempting an analysis of the Permo-Carboniferous vertebrate fauna of North America, several facts become at once apparent which are in entire accordance with evidence furnished by the beds in which the remains are preserved.

There are no forms which can be called distinctly marine.

As is well known, there are several sharks which live in brackish, or even fresh, water (see p. I24). The dipnoans and crossopterygians are inhabitants of fresh water. Correlatively it may be stated that bones of sharks and fishes do not occur in the limestones of the Clear Fork beds associated with marine invertebrates. In only a few places have bones of fishes or other vertebrates been found in limestones, and these are indeterminate fragments which might have been carried a long distance.

Amphibians are generally able to live only in fresh water, salt water, even when very dilute, commonly preventing development of the egg, and, in more concentrated form, being fatal to the individual. A recent paper by Pearse, ${ }^{a}$ however, reports the development of tadpoles in the waters of a small creek entering Manila Bay. Three analyses of the water of this creek give respectively $2.6,2 . \mathrm{I}$, and I. I per cent sodium chloride. Normally 0.6 per cent of sodium chloride is sufficient to prevent gastrulation of the egg. ${ }^{b}$ The waters of this creek were subject to tidal influence, and so the quantity of the sodium chloride undoubtedly varied, but it can hardly be supposed that it was ever below 0.6 per cent for any length of time.

Darwin $^{\circ}$ mentions that the tadpoles of certain frogs develop in sea-water on the coast of India.

Carl Wiman in I9I I reported the discovery of some long-snouted forms in the Trias of Spitzbergen, which he considered as marine amphibians. Cossman has suggested, however, that these are possibly reptilian.

Amphibians of to-day live in waters which contain an abundance of dissolved salts, mostly calcium carbonate: as Proteus of the Austrian caverns, and Cryptobranchus, etc., of the streams of the Mississippi Valley.

These facts lend support, so far as they go, to the suggestion which has frequently been made that the ancient amphibians may have been far more tolerant to the effect of sea-water than living forms. On the other hand is the fact that amphibian remains have never been found associated with marine invertebrates in a way to suggest that they lived in the same waters.

${ }^{n}$ Pearse, Philippine Journal of Seience, vol. vi, No. 4, sec. D.

b Glaser, Seicnce, vol. 36, p. 679.

- Darwin, Origin of the Specics, 6lh ed., p. $4 \mathrm{I} 4$.

d Wiman, Bull. Geol., Upsala, I9r I, vol. Ix. 
The weight of evidence is still very strongly in favor of the belief that amphibians were as severely restricted to fresh water in the past as at present.

An abundance of amphibian remains shows almost conclusively that the beds in which they occur were deposited in fresh water, or so near to a land with bodies of fresh water that the remains could be easily swept out and deposited with the material of the beds after death. The occurrence of such molluscivorous animals as Diadectes, Edaphosaurus, and Pantylus suggests the proximity of a shoreline with an abundant food-supply, but this need not have been the edge of a salt-water sea, as there were in all probability numerous freshwater and even land molluscs which could have supported these animals.

No reptiles have as yet been discovered which show a great advance in specialization toward an aquatic life.

The majority of forms are such as would lurk in secure places in the waters of lakes, swamps, or streams, or hide in the vegetation which lined their banks. Undoubtedly many of them swam freely at times, but none ever approached the high degree of aquatic specialization exhibited in the Plesiosaurs, Icthyosaurs, or Mosasaurs. Some ranged more freely in the open, or in thick woodlands and underbrush, or like Casea, perhaps, may have lived in bare and arid places, or have been like Areoscelis, at home in the branches of the treelike vegetation.

The fauna was one of estuaries, swamps, lagoons, alluvial plains, and open or covered woodlands. There is no evidence of even semipelagic forms unless it be the genus Cricotus and possibly Chenoprosopus; and no certain evidence of any forms which inhabited a marine riparian.

FOOD HABITS AS INDICATED BY THE TEETH.

The fishes, so far as can be learned from the form of the teeth, were very similar in habits to living forms in the same groups.

The amphibians show the universal carnivorous dentition; the teeth in all are simple, conical, grasping organs with slight power of mastication.

In some, as Eryops, Cacops, Trematops, etc., there were large tusks on the vomers, palatines, and maxillaries, which served as accessory grasping organs, indicating the habit of seizing more or less powerful and active prey. In other forms the teeth form a single, uniform series in both the upper and lower jaws. The larger forms were undoubtedly voracious feeders, and carried destruction into the ranks of the smaller and more helpless creatures. The bones of fishes, smaller amphibians and reptiles are abundant in the coprolites, a considerable proportion of which must be from the larger Amphibia.

The feeble dentition of Lysorophus, Diplocaulus, Cardiocephalus, etc., shows that they were confined to a diet of smaller and soft-bodied animals, worms, insect larvæ, and unprotected crustaceans and molluscs, with such dead bodies as might be discovered, and, perhaps, even some forms of vegetation.

Among the reptiles a greater variety of food habits is indicated by the character of the teeth, but so far no form has been discovered which can be 
reckoned as purely, or even largely, herbivorous. Some are clearly pure carnivores; others may have included some portion of vegetation in a diet composed largely of hard-shelled molluscs.

The synoptic statement below will give an idea of the form of the teeth in the different groups and their supposed food habits; but besides the forms mentioned there were numerous smaller reptiles, with sharp, conical teeth, which can only have been carnivorous or insectivorous.

Pelycosauria.

Poliosauridæ.

Clepsydropidæ (Sphenaeodontidæ).

All with sharp and eonical teeth, which were reeurved in some forms, and with more or less sharp and even serrate eutting-edges. Maxillary and ineisor tusks enlarged in eertain forms, someEDAPHOSAURIA. times to relatively great size. Raptorial; earnivorous.

Edaphosauridx.

Teeth on the edges of the jaws sharp and eonieal; ineisor teeth somewhat ehisel-shaped; strong erushing-teeth developed on plates on the dentaries, pterygoids, and palatines. The erushingteeth with short, sharp points when young, but wearing blunt or flat. Molluscivorous (durophagous).

Cotylosauria

Limnoscelidæ (Limnoscelis).

Labidosauridx.

Teeth all sharply eonical; enlarged ineisors in the premaxillary (sharply inclined baekward in Labidosaurus); anterior eheek-teeth somewhat larger than the posterior; ineisor-teeth of the lower jaw larger than the posterior ones, but smaller than those of the premaxillary. Carnivorous; raptorial.

Captorhinidæ.

Ineisor-teeth of the upper jaws elongate, conical. Cheek-teeth short, conieal, and strong, wearing to a flat surface; elusters of teeth on the maxillaries and dentaries. The median ones of the outer row of teeth on the maxillary larger than the others in some speeies. Habits somewhat similar to those of the Diadeetidx, but the prey confined to smaller forms. The enlarged ineisors were probably used as in the Labidosauridæ, but less effeetively, in loosening elinging molluses or extraeting such as were eoneealed in eraeks or burrows. Largely molluscivorous; not raptorial.

Diadectidx.

Ineisor-teeth ehisel-shaped; anterior eheek-teeth eonieal; no eaniniform tooth; median cheek-teeth widened transversely with more or less well-developed tubercles on the inner and outer ends, and a median eminenee, the apcx of whieh was sharp and elongated transversely to the greatest diameter of the tooth. Surface of the eheek-teeth marked by a sculpture of fine radiating lines when first erupted, but the surface soon worn to a flat or oblique surfaee. Small eonical teeth on the vomer. Molluseivorous; possibly partially herbivorous (durophagous).

Bolosauridæ (Bolosaurus and Desmatodon)

Anterior teeth in Bolosaurus small, eonieal; check-teeth large for the size of the animal, with sharp, elevated outer or inner eusps which ise above a flat surface at one side of the base. Cheekteeth of Desmatodon, the only part known, between those of Bolosaurus and Diadectes. Habits indeterminable from the teeth. ${ }^{\mathrm{a}}$

Pantylosauria.

Pantylus.

Ineisors short and blunt; very slightly larger than the cheek-teeth; eheek-teeth short, blunt cones, apex with short, sharp point when fresh; strong, blunt erushing-teeth set in plates on the maxilGYMNARTHRIA. lary and dentary. Molluseivorous (durophagous, conehifragous).

Gymnarthrus (Cardiocephalus).

Teeth flattened eonical; greatest diameter antero-posterior; increasing in size from before backward, the incisors being mueh smaller than any teeth behind them. No great power of seizing, but seemingly an ability to ehew or lacerate, as the most powerful teeth are near the posterior of the jaw. Carnivorous; not predaceous.

\section{UnCERTAin IN POSITION.}

Casea.

Teeth on the edges of the jaws short, blunt cones, few in number, and deereasing in size from before baekward. Palate eovered with short, blunt teeth. Williston says that the teeth show conelusively that it was herbivorous, and perhaps fed on soft, sueeulent meadow vegetation. This statement is not eonelusive. The teetl might have been used for hard animal food. Herbivorous (?) or carnivorous (?); durophagous.

a Broom (Bull. Am. Mus. Nat. Hist., vol. XxxiI, art. XxxiI, 19I3) has recently reviewed the work of Case upon Bolosaurus, associating parts of the axial skeleton with the skulls, whieh Case did not feel justified in doing, and has described as new a form, Ophideirus, which he distinguishes by the presence of aceessory cusps on the side of the large eusp. Williston (Se., vol. 38, p. 825, I9I3) has referred the bones of the ixial skeleton deseriber by Broom to Areoscelis. 
FOOD-SUPPLY.

The food-supply of the actively carnivorous forms is easily recognized. The large coprolites belonging to the Pelycosaurs and larger amphibians contain abundant reminders of the fate of numerous fishes and smaller reptiles and amphibians. The frequency with which armored forms occur is ample evidence of a persistent and effective campaign for subsistence maintained by the larger carnivorous forms. Unfortunately we are unable to distinguish between the coprolites of different genera or species. No single specimen has been determined as belonging with any particular animal, and so no direct evidence of the food has been found.

If we turn from direct evidence to indirect and examine the possible sources of supply, we find that little of the vegetation preserved offers much in the way of food for the doubtfully herbivorous forms. Ferns, horsetail rushes, lycopods, cordaites, cycadofilices, sphenophyllales, and conifers-no one of these could have been very readily masticated by animals with such teeth as we know. True rodent, or triturating, teeth would have been necessary for such plants as the rushes, or for tearing through the tough outer bark of the lycopods.

The abundant ferns might have furnished a food-supply if they were eaten. I find but few records of any living forms which eat fern fronds. The partridge is said to do so, and domestic animals will eat the 1ried fronds when they are taken with the hay, but not in any quantity, and not by choice. They are not touched by grazing animals. Hugh Miller, in his "Testimony of the Rocks," says that existing plants similar to the fossil flora (ferns and their allies) "contribute but little, if at all, to the support of animal life." "The ferns and their allies remain untouched by grazing animals." The roots are edible, and are rooted out by pigs and eaten. Certain North American Indian tribes dug out fern roots and baked them for food. While we can not argue with any certainty that the reptiles of the Palcozoic or Mesozoic did not eat such things, it is very probable that the fronds were as resinous or spicy then as now, and no more acceptable. Diadectes and Casea were supplied with strong claws, and the former was certainly a powerful excavator. It is possible that the roots of ferns may have formed some, even a considerable, part of the food-supply.

Very likely there were a considerable number of soft, succulent waterplants which have left no trace in the coprolites and no records of their existence in the rocks. Moreover, it is to be remembered that the remains of the animals in all probability do not occur in their normal habitat. The bones of such as are found in sandstones and shales or in the soft clays were undoubtedly swept to that place by streams from another locality where plants were possibly more abundant. In certain places, as the patches of light blue clay where the remains of small amphibians, sharks, etc., are generally abundant, plant remains are also common (see White's localities, below), indicating that the animals were entombed in or near their natural 
habitat. It is interesting here to recall to mind the feeding habit of certain turtles. Anyone who has seen a turtle attempting to devour some vegetable matter must have noticed how singularly awkward and almost helpless it seems. The food is chewed in an aimless and ineffective way, repeatedly dropped from the mouth and recovered, smeared with sand and dirt. In this way a great quantity of hard material gets into the turtle's mouth adventitiously, and undoubtedly produces much wear upon the horny covering of the jaws. If such habits are attributed to the diadectids and similar forms, it is easily understood how the original form of the teeth would be quickly and badly worn, as they commonly are in recovered specimens.

Following are the lists of plants given by White, ${ }^{a}$ from the beds of Texas and Oklahoma:

\footnotetext{
"Preliminary List of Fossils from the Main Plant Bed (M) (in the breaks of the Little Wichita, $4 \frac{1}{2}$ miles southeast of Fulda) and "Castle Hollow" (H) near Fulda, Texas.

$\begin{array}{ll}\text { Diplothema sp. ? M. } & \text { Taniopteris multinervis, } \mathrm{H}, \\ \text { Pecopleris arborescens, } \mathrm{H} . & \text { Tceniopteris abnormis, M. }\end{array}$

Taniopteris multinervis, $\mathrm{H}, \mathrm{M}$. Walchia schneideri? $\mathrm{H}$.

Taniopteris coriacea? $\mathrm{M}$.

Pecopteris densifolia? H. Taniopteris n. sp., M.

Pecopleris tenuinervis, $\mathrm{M}$.

Anniopteris n. $\mathrm{sp} ., \mathrm{M}$.

Annularia? maxima, M.

Sphenophyllum obovatum, M.

Pecopleris sp., M.

Sphenophyllum? sp., $\mathrm{H}$.

Sigillaria sp., M.

Gomphostrobus bifidus, $\mathrm{H}$

Gomphostrobus? sp., M.

Aspidiopsis sp., M.

Araucarites, n. sp., M, H.

Carpolithes sp. $\mathrm{H}$.

Aphlebia sp., $\mathrm{H}$.

Odonlopler is neuropleroides, $\mathrm{M}$.

Odontopteris fischerei? M.

Giganlopteris americana, M, $\mathrm{H}$.

Sigillariostrobus hastalus, $\mathrm{H}$.

Cordaites of. principalis, M.

Insect wings, $M$

Anthracosia, M.

Estheria, M, H.

Ostracods, M, H.

Neuropleris cf. lindahli, $\mathrm{H}$

Poacordaites cf. tenuifolius, MI.

Fish scales, M, H.

Neuropleris cordata? M.

Walchia piniformis, M.

Provisional Lisl of Fossil Plants from Perry (P) and Eddy (E), Oklahoma.

Diplothema pachyderma, E.

Pecopteris cyathea, $\mathrm{P}$.

Pecopteris geinitzi, $\mathrm{P}$.

Callipteris sp., E.

Gigantopteris americana, E, P.

Odonlopteris $\mathrm{cf}$. permiensis, E.

Neuropteris sp., E.

Taniopleris mullinervis, P, E. Taniopleris abnormis, P.

Taniopleris sp., E.

Dolerophyllum? sp., E.

Equiseliles sp., E.

Annularia stellata, $\mathrm{P}$.

Sphenophyllum obovalum, E.

Sphenophyllum cf. latifolium, P. Sphenophyllum stonkenbergi? $\mathrm{P}$. Sigillaria sp? P, E.

Walchia imbricala? P. Walchia cf. gracilis, E.

Arancariles sp., P, E.

Carpolithes, E.
}

"List of Species Provisionally Idenlified from the Permian of Kansas: (R) Wreford limestone, west of Reece; (W) shales near the Winficld formation, northeast of Washinglon; (B) Wellington formation soulh of Banner; (C) Wellington formation south of Carlton; (S) Wellington formation east of Salina.

Schizopleris cf.trichomanoides,W. Callipteris cf. scheibei, B.

Pecopleris unila, W.

Pecopleris pinnalifida, W.

Pecopleris $\mathrm{cf}$. geinilizi, W.

Pecopteris hemileloides, $\mathrm{W}$.

Pecopleris bucklandi? W.

Pecopleris polymorpha, W.

Scolecopteris elegans, C.

Cladophlebis ef. tenuis, C.

Callipleris conferla, W, C.

Callipleris subauriculata, S, C, B.

Callipleris cf. curreliensis, C.

Callipleris cf. jutieri, R.

Callipteris cf. goepperti, R.

Callipteris oxydata, $\mathrm{S}$.

Callipleris whilei, $\mathrm{B}$.

Callipleris lyralifolia? S.
Odontopleris brardii, W.

Odontopleris minor, W.

Glenopleris splendens, B, C.

Glenopleris lineala, $\mathrm{B}$.

Glenopleris slerlingi, $\mathrm{B}$.

Glenopleris lobala, C.

Neuropteris auriculara? W.

Neuropleris odonlopleroides, W.

Neuropteris scheuchzeri, W. (var.)

Neuropleris permiana, W.

Taniopleris mullinervis, $\mathrm{W}$.

Taniopteris coriacea, B, C.

Taniopleriscoriacea, var.linearis, B, C.

Sphenophyllum obovalum, C, B

Sphenophyllum cf.stoukenbergi, W.
Sphenophyllum cf. thonii, W. Sigillariostrobus hastalus, B.

Noeggeralhia? n. sp., B.

Cycadospadix? sp., C.

Cordailes principalis, $\mathrm{R}$

Poacordailes linearis? $\mathrm{C}$

Walchia piniformis, $\mathrm{R}$.

Walchia cf. filiciformis, R.

Walchia sp., C.

Voltzia sp., C.

Ullmania? sp., C.

Schülzia? cf. anomala, $\mathrm{R}$

Araucarites sp., C.

Rhabdocarpis, n. sp., R.

Carpolilhes sp., S, B.

There is little in this list that appears attractive as a vegetable food-supply.

If we search for a possible supply of animal food other than the vertebrate fauna itself, we are confronted by a rather complex problem. The beds in

a White, Proc. U. S. Nat. Mus., vol. 4I, pp. 493-516, 1912. 
which bones occur afford traces of very little that could have kept the animal alive - tracks of worms, casts, borings, etc., a few crustaceans, like Estheria, and cockroaches (Etoblattinna) - surely a very meager list. But, again, we must recall that the animals are rarely embedded in their natural habitat. This point is abundantly supported by the almost complete absence of any tracks or foot-prints where the animals occur, and where abundant opportunity was offered for the preservation of such impressions. The author has searched diligently in the shales and mud stones of the Texas beds for many days, and has found but a single foot-print of a vertebrate. Williston ${ }^{*}$ described some small foot-prints from a red shale near Abilene, in Taylor County, Texas, which show 4 toes on the front foot and 5 behind. He regards this as evidence that the animals were amphibians. The horizon is regarded as probably Triassic by Dr. Williston, because it lies closely below the Cretaceous. With this idea the author is not in accord. The beds from which the tracks were found lie in the direct line of the southern extension of the Clear Fork beds, and were so marked by Cummins. The Triassic does not occur anywhere near so far east in this part of Texas.

If, recognizing that the remains are not in their natural habitat, we turn to more likely places of abode, probably at no great distance from the places of interment of the bodies, the matter takes on a different aspect. In many places in Texas the courses of old streams may be detected in the beds (plate 5 , and plate 8 , fig. I), and if we follow one of these in imagination a little way back from the flat, swamp, playa, or lagoon into which it flowed, the possibilities of invertebrate life are found to be much greater. From the Carboniferous rocks of Pennsylvania abundant remains of lowly insects, worms, arachnids, crustaceans, decapods, and air-breathing gastropods have been collected; all exactly such forms of food as would be welcome to insectivorous animals, or forms with the blunt crushing-teeth. Abundant occurrences of cockroaches are reported by Sellards ${ }^{b}$ from Pennsylvanian and Permian beds in Kansas, and by Scudder,' from West Virginia.

The Clear Fork beds were never far from the ocean, nor free from the danger of frequent and local incursions. Shells of Myalina occur in very thin beds of limestone, 2 to 3 inches thick, in restricted areas, or even in beds of clay, in close association with beds bearing vertebrates.

In local areas in the more persistent beds of limestones occur some other marine invertebrates which would have afforded abundant food for such durophagous and conchifragous animals as may have frequented the shores or even made excursions into the sea-waters, as do Conolophus and Sphenodon to-day. It was in such conditions that the strong, chisel-like incisor-teeth of Diadectes, or the strong, backwardly inclined incisors of Labidosaurus or Captorhinus, would be useful in tearing limpet-like forms from the rocks or

\footnotetext{
a Williston, Biol. Bull., vol. xv, No. 5, 1908, p. $23^{8}$.

b Sellards, Kansas University Geological Survey, vol. Ix, p. 5or

- Scudder, Bull. U. S. Geological Survey No. 124.
} 
dragging them from cavities, as suggested by Williston. The powerful crushing-teeth of Diadectes and Pantylus would have made nothing of the shells of the nautiloids and other molluses.

Dr. White ${ }^{a}$ has given the following list of invertebrates from the Clear Fork limestone:

TABLE 2.-List of Invertebrate Species from the Texan Permian.

I. Goniatites baylorensis, n. $\mathrm{s}$.

2. Waagenoceras cumminsi White

3. Medlicottia copei W

4. Popanoceras walcotti $W$

5. Orthoceras rushensis McChesney?...

6. Nautilus winslowi Meek \& Worthen.

7. N. occidentalis Swallow.

8. N.

9. N.

I0. N.

I I. N. (Endolobus)

12. Naticopsis remex $W$

I3. N. shumardi McChesney?

I4. Euomphalus subquadratus Meek $\&$ Worthe

15. E.

I6. Murchisonia $\frac{}{\text { I7. Patella }}$ ?...

18. Bellerophon crassus Meek \& Worthen

I9. B. montfortianus Norwood \& Patten ...

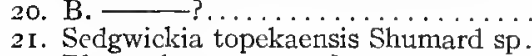

22. Pleurophorus

23. Clidophorus occidentalis Geinitz.

24. Yoldia? subscitula Meek \& Hayden

25. Myalina permiana Swallow.

26. M. aviculoides Meek \& Hayden

27. M. perattenuata Meck \& Hayden .

28. Gervillia longa Geinitz.

29. Aviculopecten occidentalis Shumard

30. Syringopora I. Spiropora

32. Cythere nebrascensis Geinitz

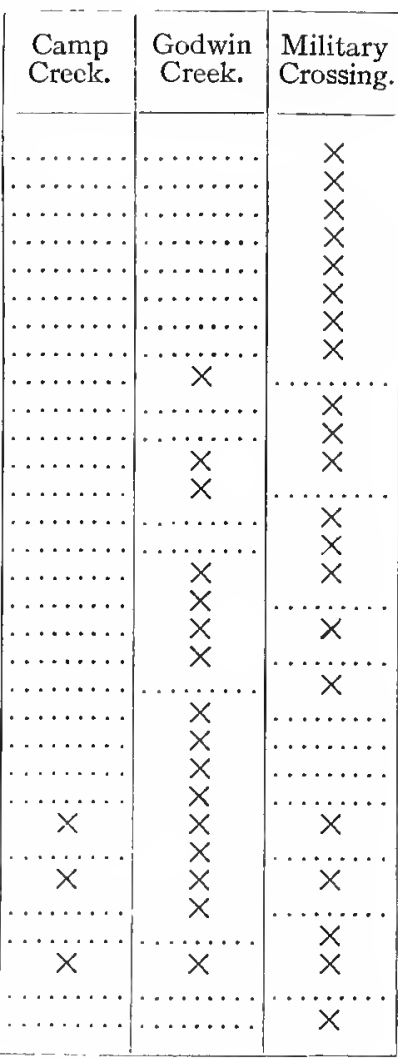

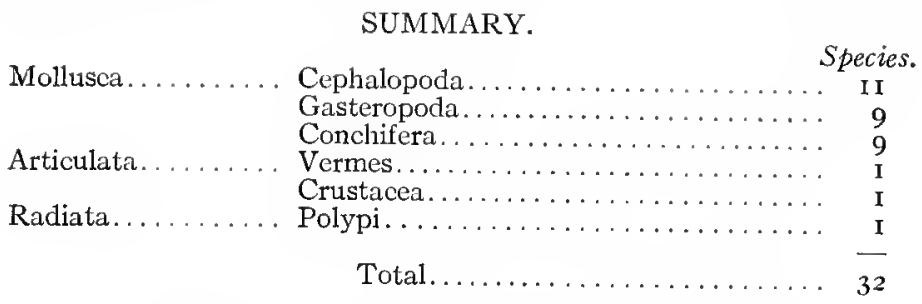

TERRESTRIAL AND AQUATIC ADAPTATIONS.

As has been remarked above, the Permo-Carboniferous fauna, with the possible exception of Cricotus and Chenoprosopus, contain no amphibians or reptiles which have advanced adaptations to an active aquatic life; there are no other forms which approach the proportions and form of the body, limbs, or skull found in forms which spend the major portion of their time in the water seeking a swiftly moving prey. Undoubtedly many of the amphibians and reptiles were accustomed to remain in or near the water, lurking in pools or swamps. 'The position of the eyes and nostrils, near the

"I. C. White, Bull. U. S. Geological Survey No. 77 , p. 16, I891.

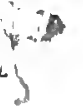


upper portion of the head, show that such forms as Eryops, Acheloma, Trematops, Trimerorhachis, etc., commonly lay nearly submerged in the water, as do the alligator and the crocodile, while in wait for their prey, but there is no suggestion in the skeleton of these creatures that they were powerful or even active swimmers. The short and stubby feet, the broad limbs, the short tails and plump bodies are those of sluggish creatures. Adaptation to an active aquatic life is shown in the Amphibia by an elongation of the tarsals, carpals, and to some extent of the phalanges.

Cricotus was undoubtedly the most powerful swimmer yet discovered in the fauna. The elongated body, with its long and slender tail; the strong chevron bones and long, spinous process of the posterior caudals; the elongated form of the skull; all these belong to an active, swift-swimming, predaceous animal.

The Dissorhophide and Aspidosauride form a group of amphibians which were probably far more terrestrial in habits than those mentioned above. The eyes were larger and more lateral in position. There is a large otic opening, probably covered in life by a tympanic membrane. The limbs are heavier and the feet shorter. The development of a dorsal armor would increase their weight, and though this would not compel a terrestrial life, as is amply shown by the presence of armor in Teleosaurus and the marine turtles, it is connected with other structures, already mentioned, which suggest habits similar to those of the land salamanders.

Among the reptiles the adaptations are more varied than among the amphibians, but not more susceptible of clear interpretation. In the Poliosauridce (Poliosaurus, Theropleura, Ophiacodon, Varanosaurus, Varanoops, and Pcecilospondylus) the body was elongate, with a moderately long tail; the skulls somewhat lengthened, with lateral orbits, but in none do the feet show aquatic adaptations, nor is there any lengthening of the chevron bones or the spines of the caudal vertebræ which would indicate a swimming tail. The bones of the feet, carpus, and tarsus, in the animals in which they are known, are all well formed, with sharp articular surfaces showing a strength only to be expected in a terrestrial or semiterrestrial animal, in which the body was more or less habitually raised from the ground and supported upon the limbs in running or walking. In only one genus, Varanosaurus, is the complete foot known; in this the strong phalanges terminated in well-developed claws. In the other genera the feet are only partly known, but in the beds where they occur, and in associations with the skeletons, are found an abundance of small, sharp, well-formed claws, which must have belonged to them; such are the claws of terrestrial animals. The members of this family probably dwelt upon the banks of streams and other bodies of water, not uncommonly taking to the water in pursuit of prey or for protection.

In the family Clepsydropidce (Sphenacodontida), Clepsydrops and Dimetrodon were relatively short-bodied, with tails of moderate length, and strong, fairly long limbs, with well-knit carpus and tarsus. The digits carried strong, 
hooked claws, which in Dimetrodon became talon-like in size and form. The elongate dorsal spines are now known to be exaggerated structures, and have no great significance as adaptations. The animals were evidently highly predaceous, able to rise from their normally prone position and develop considerable speed for a short time, as they dashed upon their prey or attempted to escape from some aggressive individual of their own kind. Dimetrodon was evidently a purely terrestrial type, but the poorer articulations of the limb bones of Clepsydrops, with its longer tail, have led to the contention that it was more aquatic. However, these are not determinate characters.

Areocelis is characterized by the extreme length and slenderness of the limb bones, the length of the feet, and the slender cervical vertebræ. These are features which are always associated with the power of swift motion and agility in leaping and climbing. Areoscelis undoubtedly equaled in speed and agility almost any living form of similar kind. It was an arboreal, active creature of great lightness and speed.

The group Cotylosauria is characterized as a whole by the extreme shortness of the neck, the generally heavy and short body, the firm union of the dorsal vertebræ, the powerful shoulder girdle, and the short and heavy limbs and feet. In life the animals were heavy-bodied, large-headed, short-tailed creatures, moving their bulky limbs in a slow, turtle-like manner, and depending for protection upon an incipient armor or their tough skin. The group contains many diverse forms, ranging from the molluscivorous Diadectes to the predaceous Limnoscelis.

Diadectes.-The broad and powerful humeri of this form, with strong processes for muscular attachment, suggest a fossorial animal. This idea is supported by the shortness and strength of the lower limb bones and the shape of the broad, powerful feet, with short phalanges and nail-like claws. The broad, depressed body, the heavy shoulder girdle, the large orbits, and the enormous pineal foramen are all characters which would go well with fossorial habits. Williston has drawn attention to the fact, however, that the fore-limbs in Diadectes, Diasparactus, etc., were too short to reach in front of the nose to an efficient extent, and pertinently queries how such an animal could dig a hole, as does a badger or a mole. It is not impossible, however, to conceive that these animals excavated shallow burrows, and it is altogether probable that the powerful limbs and feet were used in upturning the earth, tearing apart vegetation, or displacing rocks in search of their food. Abel has drawn attention to the similarity in the form of the humerus in many swimming and fossorial forms, but there seems little likelihood that Diadectes was aquatic in habit.

The large eyes, and the apparently fully functional pineal eye, may be indications of a crepuscular habit. The incipient armor of plates over the anterior thoracic ribs, and the considerable probability that there was a median row of dermal ossicles, show that the animal was subject to attack from some predaceous creatures, probably the large Dimetrodons. 
Limnoscelis.-While a true Cotylosaur, and similar to Diadectes in many points of its structure, Limnoscelis was probably much more aquatic in habit. The weak tarsus and carpus, largely cartilaginous, could not have supported the body of the animal in the posture of a terrestrial creature. The flatter head, with the orbits nearer to the upper surface, and the longer and more powerful tail, are all aquatic characters.

It would seem that we have in these two animals, very similar in a geheral way, adaptations, on the one hand, to terrestrial life, the animal feeding perhaps on littoral molluscs, and, on the other hand, to an aquatic life, the animal seeking its active prey in the water, and spending much of its time there.

The families Labidosauridee and Captorhinidae contain the smaller Cotylosaurus, which unite the general characters of the order with those of a greater agility and a more active life. The firm carpus and tarsus of the Labidosaurida, a terrestrial character, is combined with a broad, flat head, such as is usually associated with aquatic forms. It is probable that the animal lived near the shore, almost equally at home on the land or in the water. The captorhinids were probably of similar habits, but, as mentioned in the discussion of the teeth, were fitted for a diet of hard-shelled creatures.

Table showing Terrestrial and Aquatic Adaptations and Food Habits.

Amphibia:

I. Aqtatic, powerful swimmers, active, raptorial:

Cricotus, Chenoprosopus.

2. Aquatic, perhaps burrowing in the mud:

Lysorophus, Gymnarthrus, Cardiocephalus (?).

3. Semiaquatic; probably fair swimmers, slow moving, raptorial, lurking for prey:

Eryops, Trimerorhachis, Trematops, Acheloma, Zatrachys, Parioxys (?), Anisodexis (?), Tersomius (?).

4. More largely terrestrial, slow moving: Reptilia:

Cacops, Aspidephorous, Dissorhophus, Alegeinosaurus.

I. Semiaquatic, swift moving, raptorial:

Poliosaurus, Varanosaurus, Varanoops, Theropleura, Pcecilospondylus, Ophiacodon.

2. Semiaquatic, slow moving, lurking for prey, carnivorous:

Limnoscelis.

3. Terrestrial, active, raptorial:

Clepsydrops, Dimetrodon, Bathygnathus, Sphenacodon.

4. Terrestrial, slow moving, carnivorous or insectivorous: Seymouria, Labidosaurus (Littoral).

5. Terrestrial, slow moving, molluscivorous, perhaps partly herbivorous:

Diadectes, Chilonyx, Bolbodon, Bolosaurus (?), Captorhinus, Desmatodon, Diasparactus, Pantylus.

6. Terrestrial or arboreal, very active, insectivorous: Areoscelis.

7. Terrestrial, active, at least partly molluscivorous: Edaphosaurus.

8. Terrestrial, active, phytophagous ( $f$ de Williston), molluscivorous: Casea.

THE ASSUMPTION OF ARMOR AND ITS MEANING.

When, in the development of a fauna, a stage is reached where certain forms begin to assume armor, it is evident that the individuals of that fauna have reached a very perfect adjustment in their surroundings. Certain 
predatory forms have fixed upon certain harmless forms as their most desirable victims, and the harmless forms must seek safety in flight, concealment, or a defensive armor. Between the forms which seek to protect themselves by an armor and the predatory forms an active competition generally develops, the armor growing heavier and more comp!ex, and the weapons of the attacking forms becoming stronger and more efficient. More than once in the history of the earth such a competition has continued to the complete extinction of both sides, because the armor became an impossible burden, and the weapons of attack became so specialized that the food-supply was greatly restricted.

In the Permo-Carboniferous vertebrate fauna of North America this contest had reached only into its early stages. Certain amphibians, and at least one reptile, had developed more or less perfect protecting-plates on the back and sides. In Dissorhophus, Cacops, and Alegeinosaurus the distal ends of the neural spines are more or less expanded into overarching plates, and a set of secondary plates lies above and alternates with the expansions of the neural spines. In Aspidosaurus the protection was confined to the expansion of the neural spines. In Broiliellus there are dorsal shields not attached to the neural spines which are not expanded distally. Dissorophus was perhaps the best protected of this group, for the plates descended far down over the sides in a manner which led Cope to refer to it as a "batrachian armadillo." In the other genera mentioned the protecting plates are confined to the midline of the back, and in Cacops to the anterior portion only.

The armor of Diadectes, so far as known, is confined to three plates which overlie the sixth, seventh, and eighth ribs beneath the scapula. The character of the distal ends of the neural spines and the outer surface of the ilium has led to repeated suggestions that there was a series of median dorsal dermal elements, as in Pareiasaurus, and perhaps a plate, or plates, over the pelvic region, but there has been no confirmation of these ideas.

Newman ${ }^{\text {a }}$ has recently drawn attention to the fact that in the Texas armadillo the armor is not efficient in repelling the attack of dogs used in hunting it, for the dogs frequently bite through the bony dorsal plates. He suggests that the armor may be of greater use to the animal as a protection against the thick brush or thorns or even the jagged sides of narrow crevices in the rocks into which the animal crowds for safety when it is pursued. The fact that the armor is much worn in old age is cited in support of this view. If this idea is correct, it would afford some support to the suggestion of the author that the Dissorhophide and Aspidosaurida were largely terrestrial in habit.

Aside from the abdominal ribs which occur in many of the smaller forms, and which can not be reckoned as defensive armor, the only evidence of dermal scutes or scales in any member of the fauna above the fishes is found is Pantylus brevispinatus Williston, and certain loose scutes not yet referred 
to any particular form. The lack of a complete, or even fairly complete, armor indicates that while the predatory and harmless animals were becoming well adjusted to each other in the relation of eater and eaten, the condition had not yet developed to the stage it reached among the Devonian fishes, the Mesozoic Dinosaurs, or the later Tertiary mammals.

I have not considered in this discussion that the spines of Dimetrodon or Edaphosaurus were protective in character. That they may have had some such function in their incipiency, and may have developed from originally useful structures, is possible, but all the attempts, notably those of Jaekel and Abel, to demonstrate such a protective function seem to me to be based on wrong assumptions. Such spinous or tuberculated conditions of the skull as are shown in Zatrachys and Chilonyx may be regarded in the light of protective defenses, but the forms are too little known to warrant any extended speculation. They are discussed below among the over-specialized forms.

\section{OVER-SPECIALIZED FORMS.}

One feature of the Permo-Carboniferous vertebrate fauna which has, from its striking character, attracted much attention is the presence of several forms which have developed, to a remarkable degree, spines, horns, excrescences, etc. The number and importance of these forms have been exaggerated, because of their peculiarity, but a careful survey of the fauna, especially when an attempt at restoration is made, reduces this feature to a position of much smaller importance than was originally supposed. The various structures are, however, of sufficient importance to warrant a discussion of their possible origin and effect.

Dimetrodon, Clepsydrops, Edaphosaurus, Platyhistrix, Diplocaulus, and to a less degree Zatrachys are the most striking forms. The great horns on the posterior portion of the skull of Diplocaulus and the spinous excrescences on the skull of Zatrachys are different in form but similar in origin and effect to the elongation of the spines in the other mentioned genera. All are instances of the development beyond the point of usefulness of a structure which may (must?) have been originally of some value to the animal.

The conceivable causes for the development of such extravagant and apparently useless structures are:

(I) The overcrowding of a limited area, resulting in a severe struggle for existence.

(2) A wealth of possible environments, leading to the practical isolation of forms that would otherwise be eliminated.

(3) Eminently favorable conditions permitting the growth of structures far beyond an originally useful condition.

(4) The disturbance of a phylum, due to approaching extinction.

(I) The first suggestion seems to the author extremely unlikely to have been the cause of the structures here considered. The struggle for existence has many times resulted in the development of very peculiar adaptations, 
but where such a thing has happened the structures have the utmost utilitarian value. A useless or only moderately useful structure would be one of the quickest causes of extinction under such conditions. The author has for many years sought diligently for an explanation from a utilitarian standpoint for the spines of Dimetrodon, Clepsydrops, and Edaphosaurus, but he has utterly failed either to imagine any use or to gain any suggestion from others that would support such an explanation.

Abel, in his Paleobiologie (p. 430), cites a curious habit in the fishes Histiophorous gladius Brouss and Plagyodus ferox Lowe, which is substantiated by several observers. Both have enormously enlarged dorsal fins, extending nearly the whole length of the back and reaching a great height. They are both accustomed to swim near the surface, or to bask with the fins exposed, and to drift before the wind. Although the fins are totally different in structure from those of Dimetrodon and Edaphosaurus, there is a decided similarity in the external form, and here is a reminder of the original suggestion made by Cope that both these animals were aquatic. In the opinion of the author, it has been demonstrated that both Dimetrodon and Edaphosaurus were terrestrial, but he is so far from realizing any use for the dorsal fins of these reptiles that he can not refrain from mentioning the only case which has come to his notice where similar structures have an observed use.

Dr. Alexander Ruthven has described to the author his observations on a large specimen of Basiliscus, noted upon the banks of the Magdalena River, in the United States of Colombia. This individual ran out upon a rock in the river in pursuit of an insect and there encountered a strong breeze blowing upon the side of the dorsal fin. Under the pressure of the wind the animal was thrown well over to one side and seemed to have considerable difficulty in maintaining its position. Such an effect would have been decidedly increased upon animals with a fin proportionately much greater. This is but another bit of evidence that the dorsal fins of Dimetrodon and Clepsydrops were disadvantageous structures.

(2) Environment, as the author has tried to show in another paper, is a most complex conception, and can only be considered as the sum of all the contacts of any organism with the world outside of itself, both organic and inorganic. Isolation, as here used, conveys the idea of the freedom of the animal from any repressive contacts. An organism might attain such a condition in many conceivable ways, even though it were living in the midst of an abundant life. If once such a condition were attained, structures which would ordinarily be removed by selection in the struggle for existence would possibly attain an unusual development and be eliminated only because of their effect upon the animal which supported them, or cause the extinction of the animal.

(3) This suggestion is a special case of the former. In the previous suggestion we imagined the animal to be largely freed from any control of its

- Case, Oecological factors of evolution, Bull. Wis. Soc. Nat. Hist., vol. 3, p. I69, 1905. 
development by the attainment of a particular form of isolation which relieved it from the necessity of struggle. In this case we suppose the animal to have developed certain characters which enabled it to triumph easily over any unfavorable influences (contacts).

As I have reviewed the fauna time after time I have failed to discover any animal which could in any way compare with Dimetrodon in agility and strength, or in its adaptation to raptorial habits. The genus seems to be a splendid example of the development of a single group to an ascendency over all its contemporaries. The only active competition which could have occurred would have been between animals of the same genus, since the other members of the fauna were either harmless in habit or far too small to have been effective enemies. There was an abundance of food, easily obtained, no enemies of equal power, and an apparently suitable inorganic environment, surface, climate, etc. In other words, the animal was, so far as we can evaluate the factors, very perfectly adapted to its environment. (Of course, there may have been antagonistic elements of which we have no knowledge.) It had reached what Gratcap has called the "zoic maximum."

I may here quote Beecher's words ${ }^{\text {a }}$ on the effect produced upon a group by a very complete adaptation to its surroundings.

"The prolonged development or existence of a stock under favorable conditions for multiplication may be considered as one of the primary influences favoring the production of spines. This implies abundance of nutrition and comparatively few enemies outside of other individuals of the same or closely related species. Under a proper amount of increased nutrition, the vitality and reproductiveness of a stock are raised, and, other things being favorable, it is found that the stock will give expression to what has already been described as free variation. Hypertrophy is also very apt to be one result of abundant nutrition, so that structures of little or no use may be developed, and some of them comprise certain features which are often called ornamental.

"In the excessive multiplication of individuals, it is evident that there must be a great number of natural variations, and that some of these will affect the pairing of the sexes in such a manner as to accentuate and delimit certain variations. Eventually, there also comes a struggle for existence in which favorable modifications have a decided advantage. In this way it is believed that the great amount of differentiation found in some isolated stocks has been brought about. Primarily, then, a favorable condition for nutrition is assumed, which is followed by excessive numerical multiplication, while the natural variations are augmented and governed by the action of reproductive divergence for which such conditions are favorable. Secondarily, these variations are subjected to the influences of cannibalistic selection, defense, offense, sexual selection, and mimicry.

"In illustration of the amount of differentiation attained by a single stock under favorable conditions, the Amphipod Crustaceans, Gammarus and Allorchestes, found in Lakes Baikal and Titicaca, respectively, may again be noticed.

"In respect to the number of species, Gammarus is very sparsely distributed over the world, though in Lake Baikal alone II 7 species have been described by 
Dybowsky. In contrast to this, it may be mentioned that but 4 fresh-water species have been discovered in the whole of Norway. In Lake Baikal, all the depths explored (to I,373 meters) have furnished species. Those living near the surface are vividly colored, yet apparently make no attempts at concealment. Many of the species are also highly spinous, though not sufficiently armed to be protected from the fish. As these Crustaceans are voracious creatures, the spinous character has probably been favored by the agency of cannibalistic selection. The lake has a number of species of fish for which the Gammaridæ furnish excellent food, but the presence of a species of seal, predaceous fish, as well as the native fisherman, keeps the fish below the danger point, thus allowing the Gammaridæ to become very abundant.

"Similarly, in Lake Titicaca there is a wonderful specific development of a kindred Crustacean, Allorchestes. One of the most spinous species (armatus) is also the commonest, and, according to Faxon, occurs in countless numbers.

"Packard shows that among certain moths, the caterpillars, as soon as they aquired arboreal habits, met with favorable conditions in respect to food, temperature, etc., and that as spines and tubercles arose by normal variation, such features being found useful for protection, were therefore preserved and augmented.

" The differentiation of Achatinella has already been discussed as affording a striking instance of free variation among the Mollusca. The evolution of the Tertiary species of Planorbis at Steinheim, as described by Hyatt, furnishes another example, though in neither case has the differentiation of structures proceeded far enough to result in spines. The costate form (Planorbis costatus) was tending toward that end, but did not attain it.

"The series of Slavonian Paludina, in the Lower Pliocene, as elucidated by Neumayr and Paul, show a somewhat further advancement. The species in the lowest beds (typus Paludina neumayri) are smooth and unornamented. Higher in the strata they are angular and carinated, and at the top of the series the shells are carinated, nodose, and subspinose (typus Paludina hoernesi). The living American genus Tulotoma is closely related to the most differentiated species ( $P$. hocrnesi), and its approach to spinose features is more pronounced.

"Under the phylogeny of spinose forms (pp. I 8 and ig of Beecher's paper) an outline of the life history of the brachiopod Atrypa reticularis and derived species was presented. This being one of the commonest types of brachiopods in the Silurian and Devonian, often forming beds of considerable extent, it seems quite likely that its prolonged development under favorable conditions for multiplication must have had an effect on the amount and kind of variation.

"It has been noticed by Brady and others that in the Foraminifera, Globigerina bulloides, Orbulina universa, etc., the pelagic forms comprise two varieties which are generally distinct, a spinous form, and another with small, minutely granular shells. The bottom specimens of the same species are also commonly without spines, and often smaller. The interpretation seems to be that the large specimens indicate an abundance of nutrition, which also produced hypertrophy of the normal granules into spines. Some bottom specimens are large, but they are usually abnormal and of a monstrous or pathologic nature.

"From the foregoing examples, the conclusion to be drawn is that, with full nutrition, there comes a numerical maximum, and naturally with this a corresponding number of normal variations. Some of these modifications, as spines, have arisen by hypertrophy. After having thus originated by growth force, they may or may not be of use for offense, defense, or concealment, or in any way give their possessor a distinct advantage." 
Though these remarks apply to the Amphipods Gammarus and Allorchestes, and other invertebrates, it is apparent that they are just as applicable to the vertebrate Dimetrodon and related forms among the Pelycosauria. Practically withdrawn from any struggle for existence (so far as we can see) and abundantly nourished, the excess vitality of the animal was used in the elaboration of structures, possibly useful in their inception, until they became elements of weakness, and finally an efficient cause for the extinction of the group. The drain upon the animals' vitality necessary to elaborate such structures and to maintain them in repair, for they were frequently broken by accident and in conflict with other animals, could only be supported when the animal was in the height of its vigor. When for any reason the animals' powers were lessened, the support of the structure would become a disadvantage so great that it would result in the decadence of the individual and the extinction of the group.

Loomis a has argued for a "momentum of variation," or evolution, which he supports by many cases very similar to that of Dimetrodon. If such a principle exists, as seems very probable, the tendency to maintain structures already developed would be an added cause for the extinction of a group when it had commenced its decadence.

This argument is based on the belief that the spines were useless structures. Jaekel and Abel have contended that they were of distinct importance in repelling the attacks of enemies, but, as has been shown, the only enemies were individuals of the same genus, and a struggle between individuals of a genus could have no bearing on the development of the genus itself.

A similar argument can not be extended to the genera Edaphosaurus, Diplocaulus, or Platyhistrix. They may have developed their peculiar structures under conditions outlined in the second suggestion.

The line of reasoning here followed leads inevitably to the question whether the perfect adaptation of any group to its environment may not be as great a danger to the group as a severe struggle for existence. In the struggle the individual suffers, but the group represented by the best individuals survives. If the group as a whole reaches, or approximates, perfect adaptation, the momentum of variation, aided by superabundant vitality due to full nourishment and lack of effective control, would result in the exaggeration of structures until they became a fatal defect. Perfect adaptation is a possible cause of extinction.

(4) The last one of the possible causes for the development of seemingly useless structures is the disturbance of the phylum due to approaching extinction, as suggested by Beecher. ${ }^{b}$ When the high-spined forms were supposed to be the dominant types of the Permo-Carboniferous vertebrate fauna and their distribution was supposed to be much more limited than it is now known to be, this idea would have been applied to the whole fauna, but now it can 
be considered only in its application to the few genera, Dimetrodon, Clepsydrops, Edaphosaurus, and, perhaps, Diplocaulus. They were no more important in the fauna as a whole than Phrynosoma or Basiliscus is in the fauna of the regions in which they live to-day, or than Stegosaurus or Triceratops were in their time and region. It is, perhaps, of some value to test Beecher's theory in these cases.

I quote several paragraphs selected from his valuable paper, to show the line of his argument, and his conclusions. ${ }^{a}$

Page $\mathrm{I}$ : "The presence of spines in various plants and animals is, at times, obvious to all mankind, and not unnaturally they have come to be regarded as almost wholly in the light of defensive and offensive weapons. Their origin, too, is commonly explained as due to the influence of natural selection, resulting in the greater protection enjoyed by spiniferous organisms. But when, upon critical examination, it is seen that some animals are provided with spines which apparently interfere with the preservation of the individual; that other animals develop spines which can not serve any purpose for protection, or otherwise; and that spines themselves are often degenerate or suppressed organs, then it becomes evident that the spinose condition may have other interpretations than the single one of protection."

Page .2: "After studying numerous organisms, the writer is led to believe that in every case no single reason is sufficient to account for their spinose condition. The original cause may not be operative through the entire subsequent phylogeny, so that spines arising from external stimuli, and then serving important defensive purposes, may at a later period practically lose this function; or spines may become more and more developed, simply by increasing diversity of growth forces, or through the multiplicity of effects. In this way causes may follow, overlap, or even coincide with each other; but in interpreting special cases, the problems may be quite complicated, and often obscure."

Page $128:$ : *** modifications in function and structure are followed by modifications in surface, showing that the more important physiological and structural variations are the first to be subjected to heredity and natural selection, which tend to fix or hold them in check. Features of less functional importance, as peripheral characters, are the last to be controlled, and therefore present the greatest diversity, while in this diversity spinosity is the limit of progress."

Page 266: "Hypertrophy is also apt to be one result of abundant nutrition, so that structures of little or no use may be developed, and some of them comprise certain features which are often called ornamental."

Page 332: "The physiological interpretation of spinosity is a correlative of the morphological aspect of the same condition, and, as it was found that spinosity was a limit to morphological progress or regress, it will now be shown that it also indicates the paracme or decline of physiological progress. Both inferences are drawn from the individual or ontogenetic standpoint, as well as from the radical or phylogenetic."

Page 353: "It has been shown elsewhere in this article that the greatest development of spinose organisms occurs just after the culmination of a group, and, as this period clearly represents the beginning of the decline of the vitality of the group, the spines are to be taken as a visible evidence of this decadence. A similar observation has been made by Packard, who after passing in review the geological development of the Trilobites, Brachiopods, Ammonites, states that 'these types, as is well known, had their period of rise, culmination, and decline, or extinction, and the 
more spiny, highly ornamented, abnormal, bizarre forms appeared at or about the time when the vitality of the type was apparently declining.'

"Furthermore, it is now commonly agreed that all groups have been most plastic near their point of origin, or, in other words, that during their early history all the important or major types of structure have been developed. Their subsequent history reveals the amount of minor differentiation and specialization they have undergone during their period. Apparently most of the early impulses of growth, whether from the environment or from vital forces, resulted in physiological changes producing fundamental variations in function and structure. The later influences, of environment and growth force, are expressed in peripheral differentiation, and show that the racial or earlier characters had become fixed, and that the later or specific features were the chief variables. The stimuli which, during the early life history of a group, were expended in internal or physiological adjustments later produced external differentiation, and in this differentiation spinosity is the limit. The presence of spines, therefore, indicates the fixity of the primary physiological characters, together with the consequent inability of the organism to change due to its decrease in vitality."

Two things are very noticeable in these quotations, which express the tenor of the whole article. First, that Beecher believed that spines may be useless structures, and, second, that he believed that they occur when an animal has reached its maximum of vitality. I believe that the development and extinction of the Dimetrodon-like forms is amply explained by the hypotheses of Beecher and the author set forth above.

In an unsigned review of Dr. Williston's American Permian Vertebrates, and the monographs by the author on the Cotylosauria and Amphibia of the Permo-Carboniferous of North America, the Geological Magazine (Nov.Dec., I9I2, p. 5r9) says:

"These animals (Cacops, Dimetrodon, and Edaphosaurus), and many others, seem to exhibit all the features which usually occur in the last individuals of a race; they are phylogerontic, and it is improbable that they left any descendants. The Texan Amphibia and Reptiles are, then, precociously specialized examples of the earlier stocks which in South Africa slowly developed along many lines and gave rise to the mammals among other groups. Diplocaulus may be a terminal member of the line of the Microsauria, represented by Ceraterpeton and Diceratosaurus, which occur in Europe and North America."

\section{ORIGIN OF THE FAUNA. REPTILES.}

Williston " has recently stated his opinion that the old name Theromorpha (correctly Theromora) should be reëstablished to include "all the American therocrotaphic forms at least," and by implication he includes the South African Therapsida (Am. Perm. Vert., p. 7I). Broom ${ }^{\mathrm{b}}$ earlier made similar suggestions in that he insists on the close genetic relationship of the African Therapsida and the American Pelycosaurs, but as I understand him, he does not suggest their union in the group Theromora.

a Williston, Science, vol. 33, p. 632; Am. Perm. Vert., p. 71; Jour. Morph., vol. 23, p. 639 et seq.

b Broom, Trans. Roy. Soc. S. Af., vol. I, I9Io, p. 473; Bull. Amer. Mus. Nat. Hist., I910, July, p. 197. 
Broom says, in the Bulletin of the American Museum of Natural History for 19I0, page 228:

"Though it is many years since Cope first called attention to the resemblance between some of the American and African types, of later years zoologists have been more impressed by the differences. Like most others, I had regarded the resemblances as more due to a parallel development than to affinity, and I was a little surprised to find that the resemblances were of a more fundamental nature than had been supposed. Not only do certain American types resemble, somewhat remotely, of course, African forms, but the whole fauna has got an African look about it that is very striking. Williston regards the American Permian reptiles as belonging to three groups: the Pelycosaurs, the Cotylosaurs proper, and the Pariotichus group; and it certainly is very remarkable that some years ago, writing of the reptiles of South Africa, I placed them in the groups Procolophonia, Pareiasauria, Therocephalia, Anomodontia, and Cynodontia. If we unite the allied mammal-like groups, Therocephalia and Anomodontia, under the Therapsida, and omit the Triassic Cynodontia, we get our principal Permian reptiles also in three groups, and, further, the three groups correspond in many ways to the American. The Pelycosaurs resemble the Therapsida; the Cotylosaurs the African Pareiasauria, and the Pariotichus group the Procolophonia."

And further, on pages 230 and $23 \mathrm{I}$ :

"From these points of comparison I think one must conclude that the Pelycosauria are allied to the Therapsida. In some respects the former are more specialized, but in most they are more primitive. The skull, while essentially similar in the two types, is more primitive in the Pelycosauria than the Therocephalia in the retention of the quadrato-jugal and perhaps of a post-parietal and post-temporal. It is less primitive in the loss of the transpalatine. The Dinocephalia, alone among the Therapsida, retain the primitive quadrato-jugal. The Dromasauria alone have the primitive character of the lachrymal meeting the septo-maxillary, a character also seen in Edaphosaurus, and the possession of abdominal ribs, also present in some Pelycosaurs.

"In retaining the typical Diapsidan digital formula the Pelycosauria is more primitive, but though the Therapsida have acquired the mammalian formula of $2,3,3,3,3$, to suit the placing of the feet under the body, and to bring the toes into line, we can see from the condition of the metatarsals and metacarpals in the Dromasauria that this formula has probably only been recently acquired, and that the feet are not yet completely suited to the new mode of walking.

"The conclusion to which I come is that the Pelycosaurs and Therapsida had a common ancestor in the Upper Carboniferous times, which was characterized by having the typical Diapsidan digital formula, abdominal ribs, a single temporal fossa, a quadrato-jugal bone, and a Rhynchocephalian palate. Such an ancestor could be so near the ancestral Rhynchocephalia or Diaptosauria that, though it had only a single temporal fossa corresponding to the lower one in Sphenodon, it ought to be regarded as a Diaptosaurian, and though the Pelycosauria are specialized in a number of respects, I should still keep them in the Diaptosauria.

"The South African Therapsidans have sprung from the same ancestor, but have developed in a different way. By a change of habit the limbs have become more powerful, and by the adoption of the habit of walking with the body off the ground the digital formula has been changed from $2,3,4,5,3$ to $2,3,3,3,3$. The changes in the skull are of less importance, the only marked one being the loss of the quadrato-jugal. The Dromasauria are perhaps quite as near to the common 
ancestor as are the Pelycosaurs, but as they are on the mammalian line, I should keep them in the mammal-like phylum, and regard them as the most primitive division of the Therapsida."

In a recent paper on the genus Bolosaurus, Broom a reiterates his views and presents further evidence.

Watson, in a recent paper, ${ }^{b}$ has expressed his idea of the necessity of uniting the North American and South African forms. After a detailed discussion he says:

"The final result is that the presence of the Deinocephalia makes it impossible to exclude the American Lower Permian and Carboniferous Pelycosaurs from the later South African Therapsids. Such a division could any time have been drawn only on the more primitive limbs and large quadrate of the early forms; the fact that in Deinocephalia we have types with a quadrate as large as that of the Pelycosauria combined with modernised limbs renders the foundation of a great group division on these characters quite impossible.

"For this great stem of the Reptilia, including all the mammal-like reptiles, many names are available. I am myself inclined to extend Broom's Therapsida, a most appropriate name, to the whole of them, but I fully recognize that Cope's earlier names of Theromorpha and Theromora have been used in the same sense; these names were never very clearly defined by Cope, and have at one time or another included nearly all Permian reptiles. If any one should wish to resuscitate these names in this connection, I would point out to them that Owen's term Anomodontia was used by that author in 1860 in a wide sense to include the Dicynodonts and also carnivorous Therapsids from South Africa, and has at least as good a claim to be used as Cope's later terms."

Broom and, especially, Williston insist upon the hopelessness of any attempt to present a permanent classification of the early reptiles at the present time when only a portion of the fauna is known, and that portion, in the main, forms fragmentary skeletons. It is largely in recognition of the inadequacy of our information and the failure of many recently proposed classifications by Osborn, Jaekel, and others, as I understand Dr. Williston, that he proposes a return to what he considers a stable basis, and proposes to unite the Pelycosauria, Proterosauria, Caseasauria, Kadaliosauridæ, and the Therapsida as suborders under the old order Theromorpha.

His classification is as follows:

Order Theromorpha:

Suborder Pelycosauria.

Family Clepsydropsidæ (Sphenacodontidæ).

Family Poliosauridæ.

Family Edaphosauridæ.

Suborder Proterosauria.

Family Paleohatteridæ.

Suborder Caseasauria.

Family Caseidæ.

Suborder - - .

Family Kadaliosauridæ (Aræoscelidæ).

a Broom, Bull. Amer. Mus. Nat. Hist., vol. 32, p. 515, 1913.

b D. M. S. Watson, Proc. Zool. Soc., London, vol. 1914, p. 778.

Williston, Jour. Morphology, vol. 23, p. 649. 
As he says, the classification does not take into consideration the tendencies of evolution in the group.

"I am aware that this classification is what might be called 'horizontal,' rather than 'vertical;' but I also insist that horizontal classifications are absolutely imperative until such time as we have more than vague surmises and guesses as to the true lines of phylogeny."

The opposite point of view is adopted by Osborn in his paper on the "Reptilian Subclasses Diapsida and Synapsida, and the early history of the Diaptosauria." He says: ${ }^{2}$

"In my opinion classification should directly follow, formulate and express our progressing knowledge of phylogeny; for example, if the Proterosauria prove to be ancestral to the Dinosauria, as I suspect, then the order Proterosauria should be transferred to the superorder Dinosauria, as constituting a common stirp, a common blood relationship, a common tendency to evolution. As soon as a certain evolutionary direction is assumed by a certain group of animals toward a higher group, although the evolution may not have proceeded very far, the lower and the higher groups should be united in classification, and thus segregated from groups diverging in other directions."

After all, these two writers are not far apart, for, were Dr. Williston convinced of the correctness of the phylogenies proposed, he would assuredly follow the plan suggested by Osborn.

The author has discussed the early reptiles in great detail with Dr. Williston, and is in accord with him in most of his statements and conclusions, but can not entirely agree with him in his proposed classification. He is inclined to think that Dr. Williston has assumed too conservative a position in the matter, and to think that enough of the main phylogenetic lines are determinable to warrant a more definite statement.

Williston, in his analysis of the Permo-Carboniferous reptiles, gives the following list of constant characters in the Theromorpha:

One or two temporal vacuities on each side.

Neck of greater length.

Neural arches never stout.

The last character can not be strictly maintained, as Pxcilospondylus Case has the neural arches of a portion of the vertebral column quite stout. This is the only exception to the rule, so far as I know.

The contention of Dr. Williston is that all the other characters, inconstant ones, are not sufficient to separate the American and the South African forms ordinally, and they must be combined. But the constant characters are extremely primitive, exactly such as would be found in a common ancestral group, and are such as might be retained in many variations in widely divergent lines.

Although it is frankly admitted by the author that divergence has not gone far enough in the Permo-Carboniferous reptiles to eliminate all the 
resemblances between the South African and the American forms, he believes that it is possible to demonstrate a well-established tendency in their evolution and well-established stages of evolution in different lines of these reptiles, and he believes that this is the essential point in any true classification, which must consider the phylogeny of a group.

Broom has shown and insisted upon the important tendency in the evolution of the South African forms toward the lengthening of the limbs, the strengthening of the tarsus and carpus, a reduction of the digital formula to $2,3,3,3,3$, the change in the pelvis and scapula, the reduction in the size of the bones in the articular region of the jaw, and the enlargement of the squamosal with a coincident reduction of the quadrate. He says: ${ }^{a}$

"The Pelycosaurs were slow-moving crawlers with short, lizard-like limbs; the Therocephalians were active runners, with mammal-like limbs. The structure in the limb girdles is in harmony with the differences in the limbs."

Again: ${ }^{b}$

"If this conclusion be correct, we may regard the American and South African Permian faunas as derived from a common origin, but having evolved in quite different directions. The American types undergo many curious specializations. The African, or more preferably the South Atlantic type, is chiefly remarkable for the great development of the limbs. The Pareiasaurians, the Dinocephalians, the Therocephalians and the Anomodonts have all developed powerful limbs, and not improbably all independent of each other. What may have been the cause we can not at present tell, but it was a most fortunate thing for the world. It was the lengthened limb which gave the start to the mammals. When the Therapsida took to walking with its feet underneath, and the body off the ground, it first became possible for it to become a warm-blooded animal."

None of these points would Williston dispute. If he were to simply insist that the South African and the American Permo-Carboniferous reptiles were a heterogeneous group, with many distinct specializations, but retaining certain primitive characters upon which the specializations were based, there could be no contention, but to fail to fully weigh the manifested destiny of radically different groups seems to the writer too conservative to express the state of our knowledge. While agreeing with Williston in the futility of attempting a detailed classification, the author desires to express his opinion of the situation as follows:

(I) American Permo-Carboniferous Therocrotaphic reptiles (Pelycosauria). With primitive characters allying them to the African Therapsida, and pointing to a common ancestor, but with all their specializations upon a reptilian theme, and leading to extinction, or higher reptiles.

(II) South African Permian Therocrotaphic reptiles (Therapsida). With primitive characters allying them to the American Pelycosaurs, and pointing to a common ancestor, but with all their specializations upon an advancing theme, and leading to extinction, or to the Mammalia.

a Broom, Trans. Roy. Soc. S. Af., vol. I, I9Io, art. 2.

b Broom, Bull. Amer. Mus. Nat. Hist., vol. 28, art. 29, p. 234, I9Io. 
This goes no further than to state the author's belief that the American and South African forms had developed sufficiently far to indicate their main lines of evolution so clearly that we are able to recognize that they belong to separate phyla. ${ }^{2}$

As has been repeatedly intimated in this discussion, the group called Pelycosauria is now recognized as a composite group, and while I am unable to agree with Dr. Williston that they should be grouped with the South African forms as Theromora, I do agree with him in his subdivision of the fauna into distinct groups. If I am mistaken in his views, and he is inclined to restrict the Theromora to the American forms, as he apparently does in his Review of the Primitive Reptiles (p. 649), then I think we are together, accepting the Theromora as a provisional order. My arrangements would be only slightly different from his:

Order Theromora.

Suborder Pelycosauria.

Family Clepsydropidæ (Sphenacodontidæ).

Family Poliosaurida.

Suborder Edaphosauria.

Family Edaphosauridæ.

Suborder Proterosauria.

Family Paleohatteridæ.

Suborder Caseasauria.

Family Caseidæ.

Suborder Kadaliosauria.

Family Kadaliosauridx.

Family Areoscelida.

Edaphosaurus can not justly be retained in the Pelycosauria. The genus is as distinct from either Clepsydrops or Dimetrodon as is Casea or Areoscelis. The high spines which gave the original idea of a kinship with Dimetrodon can only be regarded as a parallel character, found also in Platyhistrix. The bones of the skull are uncertain. Case and Broom, not being in accord on all points, and Williston agreeing with neither. But the possible extent of the lachrymal to the nares (Broom and Williston); the possible presence of postparietal bones; the totally different dentitions and diet; the different shape of the axis; the different proportions of the upper and fore arm and leg; the presence of an ectepicondylar foramen in the humerus; the different shape of the ilium and femur; the totally different habits of life, are sufficient to place it in a separate suborder.

The Poliosauridæ, generally grouped with the Pelycosauria, are equally close to the Proterosauria, as suggested by Williston. The imperfectly ossified condition of the pectoral and pelvic girdles are explainable upon the hypothesis of an aquatic adaptation, which is borne out by the presence of the sclerotic plates (Williston), and admitted as possible by Osborn because of the distal expansion of the humerus and the imperfect ossification of the

a Broom's citation of the similarity of the structure of the jaw in Pelycosauria and Dinocephalia (Bull. Amer. Mus. Nat. Hist., vol. 33, art. 9, I9I4, p. I4r) is but an instance of a line of a general group which, departing from, or, better, refusing to follow, the manifest destiny of its relatives, suffered the usual fate, extinction. 
tarsus and carpus. The possibility that all the specimens described by Credner are immature, as suggested by Osborn, must not be lost sight of.

We know nothing of the feet of the Poliosauridæ, other than in the genus Varanosaurus, but these are the feet of a typical land reptile, with wellossified interlocking elements in the wrists and ankles. I can not but believe that the ideas proposed in my first monograph upon the Pelycosaurs were correct; that the series represented by Poliosaurus, Clepsydrops, and Dimetrodon is a morphological series, representing stages in the development of the phylum, and if we add to this series, as a beginning member, a Proterosaurid individual, we would have representatives of the group from its inception to its extinction.

Not improbably the Caseasauria, Kadaliosauria, and Edaphosauria were derived from some lower member of this line. This would in no wise exclude Osborn's hypothesis that the Dinosauria were derived from the Proterosauria.

The origin of the Cotylosauria directly from the Stegocephalia has not been questioned by those familiar with the group. That no one of the known forms can be considered as a connecting link is well accepted. Seymouria and Pantylus are both very close to the Amphibia in the characters of the skull, but neither of these is conceivably in the direct line. It is practically certain that we must turn to one of the smaller, less well-known forms, Pariotichus, Isodectes, Sauravus, Eosauravus, Ectocynodon, or some similar form, for the connecting link. As in every case of a proposed phyletic series, we can approach more or less closely to a point of union from both sides, but the known forms are all too highly specialized to occupy the exact position.

The Amphibia are all closely connected with the true Carboniferous amphibians - so closely that we can only see in them a direct continuation of the phylum. 


\section{CHAPTER VIII.}

\section{DESCRIPTION OF INDIVIDUAL GENERA.}

PISCES.

A review of the list of fishes (see table, page 96) shows that by far the larger number were inhabitants of fresh or brackish waters. Indeed, it is doubtful whether there were any which were truly marine. Of the sharks we know little, but it is a well-established fact that some of the living forms of this group are inhabitants of fresh waters, and Dollo has asserted that the form of the caudal fin and the archipterygium form of the lateral fins in Pleuracanthus indicate a fresh-water habitat and are benthal in character. ${ }^{2}$

Pleuracanthus.-Carnivorous, benthal, and fresh-water. ${ }^{b}$ Size, form, and proportions unknown.

Diacranodus, Ctenacanthus, and Anodontacanthus (and possibly Hybo$d u s$ ).-These were all carnivorous forms, and probably of the same general habits as Pleuracanthus. Known only from spines and fragments.

Janassa.-This was evidently a mollusc eater, and from its broad and ray-like form probably kept close to the bottom in shallow water. ${ }^{c}$ Known only from the teeth in America.

The Dipnoans and Crossopterygian and Actinopterygian ganoids were all dwellers in fresh and brackish waters. So little is known of these forms in the Texas fauna that it would be useless to attempt to describe any of them, but it is.important to note that not one is indicative of the presence of salt water. Their remains always occur in sandstones and clays or shales associated with amphibian and reptilian bones, and never, so far as I have observed, with marine invertebrates. This all goes to confirm the supposition that the Texas deposits, other than some of the limestones, were laid down in pools upon the surface of a delta or flat beyond the reach of marine waters.

AMPHIB1A.

The following descriptions and restorations include only the better-known genera:

Diplocaulus (fig. 13).-A great deal of work has been done upon the genus and descriptions of the skull, vertebral columns, and parts of the limbs have

- Among living fresh-water Selachians are the following: Carcharias gangelicus is found high up in the rivers of India, and also in the Tigris River near Bagdad, 300 miles from the Persian Gulf. The same shark is found in a lake on Viti Levu (Fiji Islands), which is shut off from the sea by a cataract. Carcharchinus nicaraguensis is found in Lake Nicaragua and its outlet, the Rio San Juan. This shark is confined, so far as known, to fresh waters, and is the only strictly fresh-water shark recorded.

b Dollo, Bull. de la Soc. Belge de Geol. de Pal. et d'Hydrol, Tom. xxI, I906.

- Jaekel, Geol. Gesell. Zeitsch., I899; Zittel (Broili), Grundz. d. Paleon., sec. ed., p. 62, figs. I07-I09. 124 
been published. We now know the skull, practically all of the vertebral column, the interclavicle, clavicles, coracoid, humerus, femora, and some of the metapodial bones. For a long time after it was discovered no bones of the limbs, feet, or pelvic and pectoral girdles were found associated with the skulls and vertebræ, and the animal was considered to be limbless. Williston first discovered and described the limbs and the coracoid. The broad skull, terminating behind in the heavy horns of solid bone, and the large plate-like clavicles and interclavicle, show that the normal position of the animal was flat upon the belly. The limbs were short and relatively weak; the posterior a little larger than the anterior; the body slender, terminating in a long tail.

It is possible that Diplocaulus may have been able to move with considerable rapidity through the water, driven by its strong tail. Broili suggests that the presence of zygosphene and zygantrum articulations between the vertebræ indicates some rapidity of motion. The weight of the absurdly large head at the extremity of the slender body suggests considerable mechanical difficulty in the act of swimming. The head would have constantly

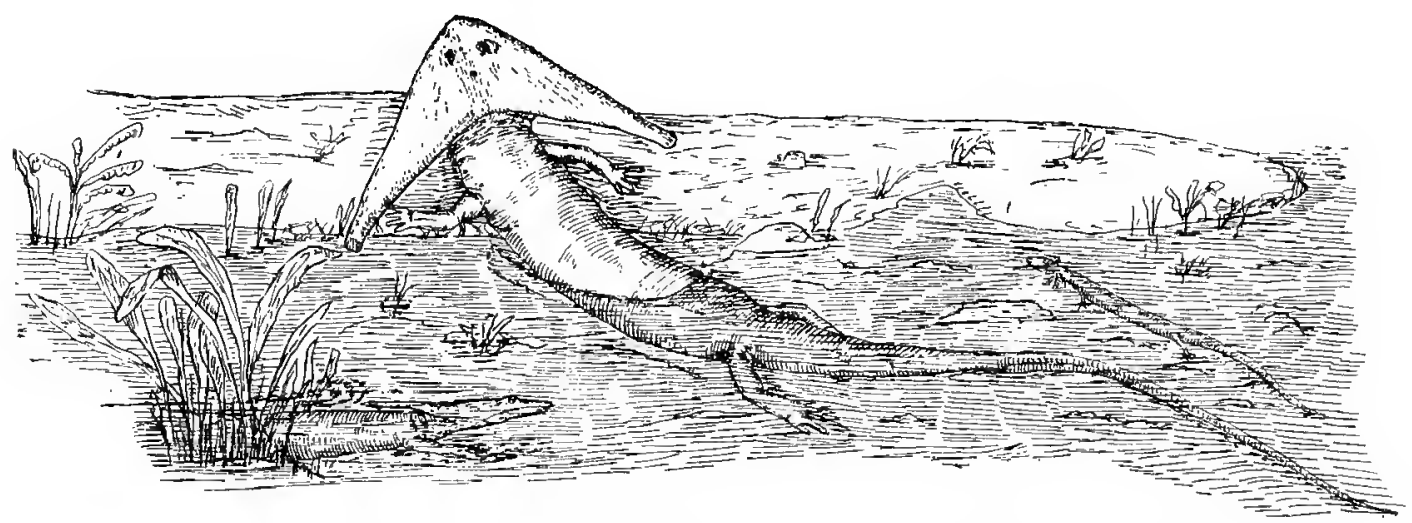

FIG. 13.-Restoration of Diplocaulus magnicornis Cope and Lysorophus tricarinatus Cope.

dragged downward, compelling a sustained effort of considerable power to maintain a uniform lateral or upward motion. The broad, flat head might have acted as a guiding-plane to the animal's motion and, as long as held horizontal or pointed upward, would maintain the animal's direction, but the weight would soon drag it down, for there were no muscles or ligaments adequate to support it, as is shown by the lack of an enlarged neural spine upon the axis. It is to be noted, however, that the articular condyles lie almost equally distant between the two extremities of the skull and the skull may have been so balanced upon them as to give some freedom of movement.

It is far more probable that Diplocaulus habitually lay upon the bottom of pools or streams, advancing by a wriggling motion, somewhat in the fashion of Necturus, aided by the weak feet, or driven by strokes of the powerful tail. The location of the eyes and nostrils, entirely upon the upper surface of the skull, is just such as would be most useful to an animal with such a habit. Moving sluggishly over the slime of the bottom, it would devour 
such weak-shelled or soft-bodied invertebrates, crustaceans, worms, insect larvæ, etc., as it might discover, and it probably did not refuse carrion, or even vegetable matter of some kinds.

It has been suggested that the great projecting horns may have sheltered external gills, but of this we have no knowledge. Perhaps the animal rose to the surface at long intervals for air, or pushed its nose beyond the edge of the water along the bank. Mr. Paul Miller has noted the fact that the bones of Diplocaulus are almost always associated with the teeth of sharks, which may be taken as confirmatory of the fresh-water habits of ancient sharks, and perhaps as an indication of a favorite food.

A tracing of a nearly complete specimen furnished the author by Mr. Doughtett measures approximately $950 \mathrm{~mm}$. This would be a good-sized individual of Diplocaulus magnicornis.

Eryops (plate 20, fig. 2).-The skeleton of the genus, typically represented by Eryops megacephalus, is as completely known as any form from the PermoCarboniferous Red Beds. It was the largest of the amphibians, reaching a length of 6 feet or more. If, as restored in the American Museum of Natural History in New York, it had a long tail, the length may have been even greater. Dr. Matthew assures me that the long tail is warranted by specimens which I did not see when working upon the collections in the American Museum. Neither Dr. Williston, Mr. Paul Miller, nor myself, all of whom have collected several times in the Texas beds, has seen any evidences of such a long tail, and I have collected two specimens in which the nearly perfect vertebral column indicated that the tail was decidedly short, as I have restored it. (Carnegie Inst. Wash. Pub. I45, plate 9.) It is also to be noted that in the original figure of the vertebral column given by Cope ${ }^{a}$ the vertebræ, which he speaks of as having coössified chevrons and near the extremity of the tail, are still of good size, indicating that there was a rapid decrease in the size of the caudal vertebræ and a short tail, if his observation of the position of these vertebræ is correct. The bifurcated distal ends of the neural spines of the anterior caudal vertebra afford some support to the idea of a long tail, as they would have given attachment to powerful muscles and tendons.

Long-tailed or short-tailed, Eryops was a heavy-bodied Stegocephalian, with a large head and relatively short limbs. The bones of the limbs show the attachment of powerful muscles, and the carpal and tarsal bones were well formed and closely articulated. The clavicles and interclavicles were relatively small and the pelvis was a solid mass of coössified elements. The foot, as indicated by the phalanges, was short and strong. Altogether the skeleton gives the idea of an animal with considerable ambulatory powers, able to raise the body well off the ground in progression; a totally different creature from the weak-limbed Triassic Metopias, with its great pectoral shield formed of the clavicles and interclavicle, which protected the thorax

\footnotetext{
${ }^{a}$ Cope, Proc. Amer. Phil. Soc., vol. xIX, pl. II I, I880.
} 
as the body was shoved forward on the ground. The thoracic ribs were somewhat expanded, as in several amphibians of the same fauna, probably as a partial protection against some prowling Dimetrodon, which would have had Eryops at a decided disadvantage if the encounter took place upon the land.

Undoubtedly Eryops spent much of its time in the water, and found there its chief food supply. The position of the eyes and nostrils near the top of the skull shows that it could, and probably did, lie nearly submerged in the water until the approach of some fish or small amphibian or reptile was sufficiently close to warrant a sudden rush with its enormous jaws distended, and by a sudden snap drive home the powerful tusks, from which there was no escape.

No coprolites have been definitely associated with the skeletons of Eryops, but large ones occurring in great abundance in the same beds contain remains of fishes and small bones of other vertebrates.

The bones of this animal are among the most common in the Texas and Oklahoma beds, and have been found in Kansas, Illinois, and Pennsylvania. Evidently the genus was represented by numerous individuals and was widely spread over the continent.

Closely related to the Eryops were Parioxys and Anisodexis, known only from the skulls, but while they were probably of similar form and habits, they were smaller and possibly more active. It is probable that fuller knowledge of the fauna will record many more forms related to this genus, and may prove that forms known from areas as widely separated from the Texas locality as New Mexico, Illinois, and Pennsylvania should be placed in distinct genera.

Acheloma.-This genus is known only from the skull, a part of the pectoral girdle, ribs, humerus, and an incomplete vertebral column. We may not as yet attempt a restoration or hazard a guess at its habits. The peculiar form of the scapula-coracoids is undoubtedly associated with some activity which we can not surmise. The anterior ribs are expanded distally, probably for protection against some active predatory form. It probably did not exceed $800 \mathrm{~mm}$. inlength.

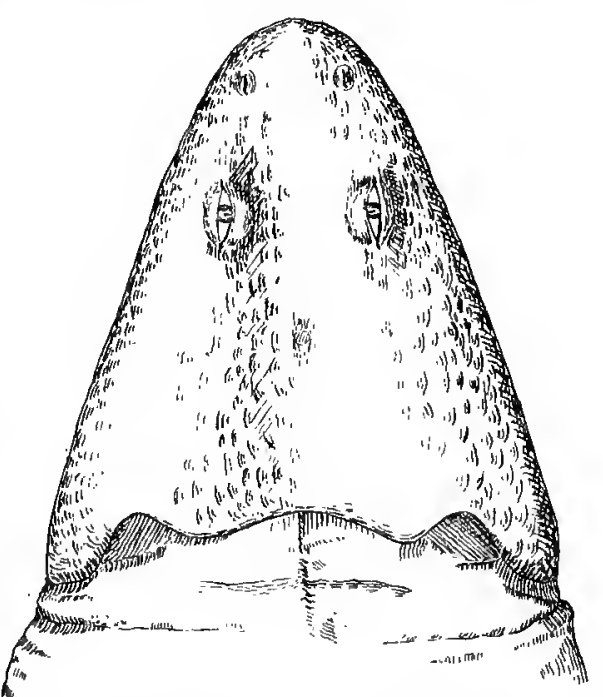

FIG. 14.- Restoration of the head of Trimerorhachis sp. About one-half the size of an average specimen.

Trimerorhachis (fig. I4).- The genus is known only from the skull and a few vertebræ. Some limb and girdle bones have been assigned to the genus, but only tentatively. It is unfortunate that more is not known of Trimerorhachis, for it is one of the most primitive amphibians in the fauna. The skull is longer than wide, with the nostrils at the anterior end and the eyes in the 
anterior half of the skull. The clavicles were large and plate-like, and formed some protection to the thorax. The vertebral column, composed of very thin intercentra, pleurocentra, and neurocentra, with a very large inner space for the notochord, must have been very weak and very flexible. The proportions of the limbs are unknown, but any bones which can be assigned to the limbs of the genus are relatively short and weak, with poorly developed ends showing the presence of a large quantity of cartilage in the joints. It is probable that the carpus and tarsus were also very weak, with few of the bones ossified. We must think of this animal as probably slender, softbodied, and salamander-like, with weak limbs and perhaps rather elongate feet. The last idea is suggested by the probability that Trimerorhachis was largely aquatic, and progressed by swimming.

It probably lived in very much the same surroundings as the modern mudpuppies, and probably had very similar habits. Large individuals may have reached a length of I meter, but most of the skulls recovered indicate a smaller size.

Zatrachys (fig. I5).-Known only from the skull, this genus can not be restored, nor very fully discussed, but certain peculiarities of the skull demand comment. The development of processes on the edges of the skull, forming a sort of coarse serration of the periphery, except on the anterior end of the nose and the middle of the posterior edge, is perhaps associated with the peculiarly complex nature of the cranial sutures. The midline of the skull is depressed and there are deep pits in front of each orbit, which probably lodged some sensory gland in life. The nostrils are far back from the anterior end of the skull, and the space between and anterior to them is peculiarly flat. Broom has recently recorded his opinion that there is a median opening in the anterior end of the skull as in Trematops. While we can hazard no guess as to the form of Zatrachys or its habits, we may be sure

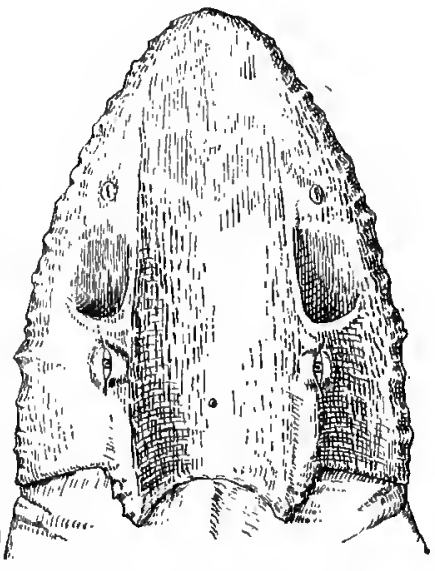

FIG. r5.- Restoration of the head of Zalrachys microplhalmus Cope. About one-half natural size. that it was a highly specialized type, and was perhaps reaching that stage of its development where approaching decadence is heralded by a development of spiny processes. It may be a terminal member of some one of the many branches of the great phylum to which Trimerorhachis belonged.

Dissorophus and Cacops (figs. I6 and I7).- The first is the most specialized of the three similar genera which are united in the family Dissorophida. All of them have a more or less complete dorsal armor composed of the expanded distal ends of the neural spines, alternating in position with overlying dermal plates. In Cacops and Alegeinosaurus, the armor was limited to the midline of the back, and does not descend upon the sides of the body. In Dissorophus the plates are longer, and came well down over the sides of the 
body. The head was short, with large eyes and large auditory openings which were covered by a tympanic membrane. The limbs were proportionately long; the humerus of Dissorophus is nearly as long as the skull and the femur fully as long or longer; the wrists, ankles, and feet were well formed and strong, but rather broad, the tarsal and carpal bones being rather disklike, and without strong articular surfaces, as compared with the same elements in Eryops. The tail was short. The large eyes, well-developed auditory sense, and proportionately long limbs show that these animals were

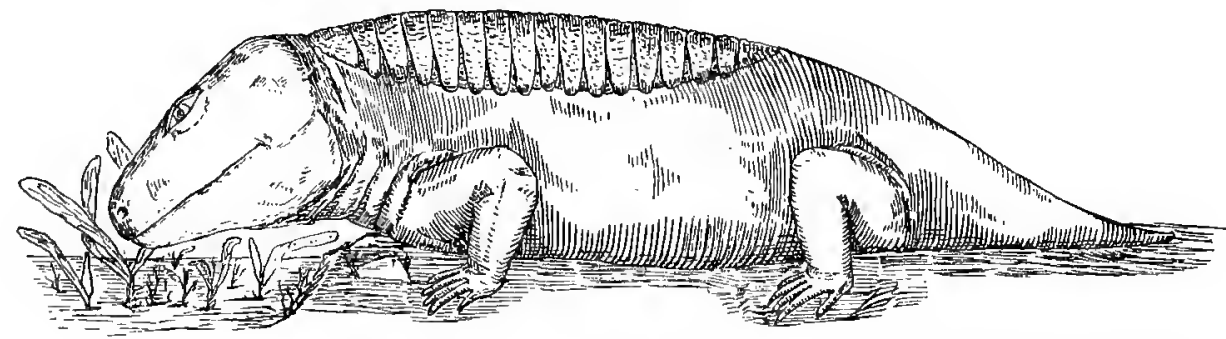

Frg. 16.-Restoration of Dissorhorphus multicinclus Cope. About one-fifth natural size.

probably more alert than most of the amphibians of their time, and capable of rapid and sustained motion. It was probably just this alertness and ability to get around which brought them into the danger from predatory reptiles, and made armor necessary.

Cacops.-Williston has remarked upon the frog-like appearance of the Cacops skeleton, especially shown in the large head and pectoral region, the short neck and tail, and the posterior limbs longer than the anterior. He has

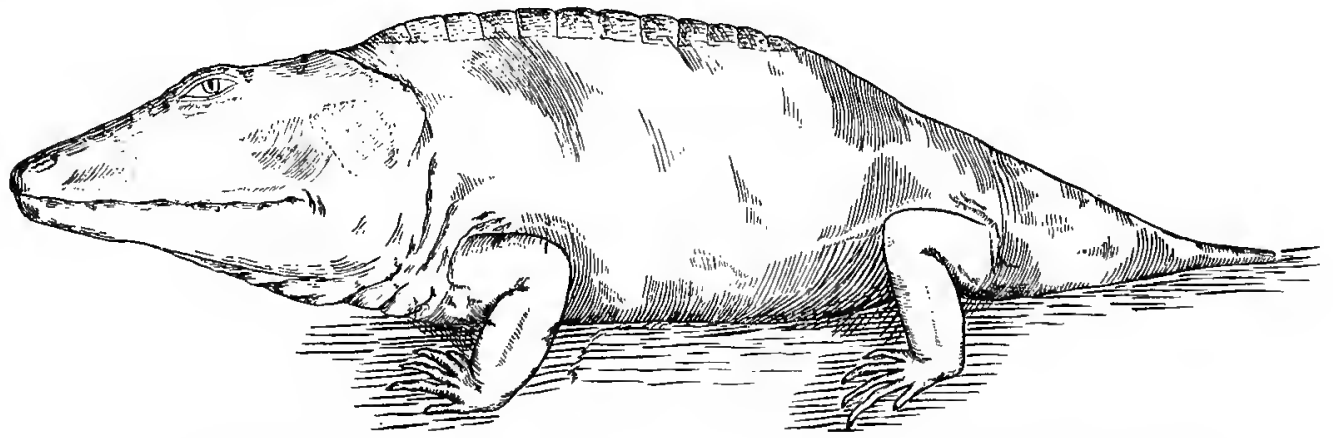

FIG. I7.-Restoration of Cacops aspidephorous Williston. About one-fourth natural size.

also shown that the toes were without claws, and suggests that the feet were webbed, and that the animal was a good swimmer. The presence of armor is no objection to the assumption that the animals were largely aquatic, but the high development of the senses of sight and hearing, the evident agility, and the location of the armor on the back, suggest that the animals frequently sought the shore, and even ranged freely upon the land. In the water the attack would be at least as much from below as from above, and the dorsal armor would have no special value, but on the land such small creatures would be most likely to be seized from above, where even the begin- 
ning stages of armor would prevent injury to the spine on many occasions. The possibility that the armor may be considered as an evidence of a terrestrial habit has been noted above.

Abel, in his Paleobiologie, has suggested the correlation of dorsal armor with fossorial habits in extinct amphibians and reptiles, but it could not be the case with Cacops, which was devoid of strong claws.

Its habits were possibly similar to those of the living frogs, lurking in the vegetation on the banks of bodies of water, sometimes wandering inland, but always ready to make a quick rush to the protection of the water when danger threatened. The total length did not exceed 45 centimeters.

Aspidosaurus (fig. I8).- This genus did not develop a dermal armor, but the distal ends of the neural spines were expanded to a greater or less degree, and undoubtedly furnished some protection to the animal. It is not probable that the bony process projected for any distance above the line of back (unless it were in the case of Aspidosaurus crucifer). Any attempt to restore

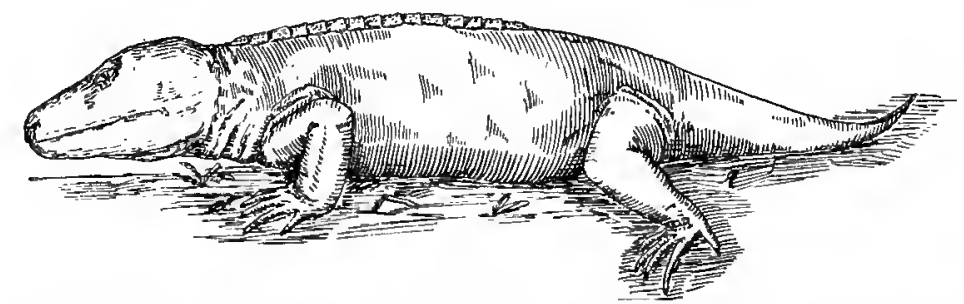

FIG. 18.-Restoration of Aspidosaurus chilon Broili. Probably about one-fourth natural size.

these animals would be almost wholly conjectural. A. novomexicanus had a skull similar in general proportions to that of the members of the Dissorophidce, but nothing more can be said with certainty. We can only imagine it as a stegocephalian, with the general form of Cacops or Dissorophus, devoid of any armor, but perhaps with a row of projecting knobs on the back.

Broiliellus. - In a recent paper Williston a has described a new amphibian, Broiliellus texensis, from the Clear Fork beds of Texas. In this animal there was a single row of dorsal dermal plates which were entirely free from the ends of the neural spines, and the ends of the neural spines were not expanded. This is the third type of armored amphibian in the fauna. Dissorophus has the extremities of the neural spines expanded into overarching plates, and this is overlain by dermal plates of similar form. Aspidosaurus has the ends of the neural spines expanded without overlying plates. Broiliellus has the dermal plates without any expansion of the end of the neural spines. Williston thinks that the expanded ends of the neural spines in Aspidosaurus are really dermal plates which have become secondarily coössified with the neural spines. The author has not held this idea and can not now accept it for all cases. The only evidence he has that such an action may have taken place is that in the Brier Creek Bone Bed he found a V-shaped dermal plate very similar in appearance to the terminal process of an Aspidosaurus, but which 
was evidently free from the neural spine during life. Very slight rugosities on the lower side indicate a weak attachment to the spine. However, as this plate occurs in the Wichita, and Aspidosaurus has never been found below the Clear Fork, it is very possible that it represents a distinct form.

Trematops (fig. I9).-As suggested by Williston, Trematops must be a close relative of Eryops, and there can be little doubt but that its habits were similar. The head was proportionately larger, and shows some very different structures, as the postorbital openings (closed otic notches), the elongate nares, or nares united with preorbital openings and the median opening between the premaxillaries. There can be little doubt that the anterior median opening, and perhaps a part of the elongate openings which include the nares, were the seat of glands of some sort, perhaps connected with the lateral line system. What the use of such glands could have been we can not conjecture, but it is very possible that some sense was located in them which we can not appreciate. In reading Dean's account ${ }^{a}$ of the feeding habits of the Lung Fish, one is impressed with the possibility that these lowly animals may have had a totally different means of receiving impressions from the external world than those which we usually attribute to them.

The body of Trematops was not unlike that of Eryops. Williston believes that it had a short tail, such as is common in heavy-bodied amphibians.

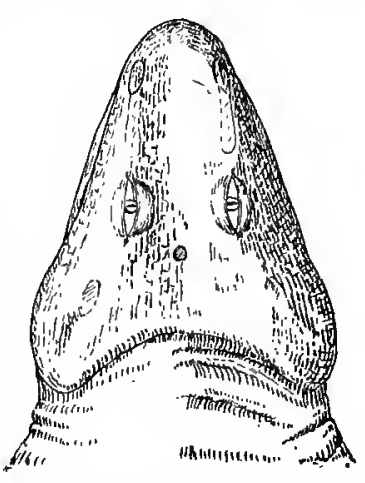

FIG. 19.--Restoration of the head of Trematops milleri Williston. About one-fifth natural size.

Lysorophus (fig. I3).-This rather widely spread genus, found in Texas, Oklahoma, and Illinois, was a slender, snake-like perrenibranchiate. Williston has found minute limb bones in the nodular masses which inclose the skeletons of Lysorophus, and is inclined to believe that they belong to that genus. This is not improbable, but it must be remembered that there are other forms found in the same places and in the same nodules, and the limb bones may have belonged to any one of the genera, or all may have possessed them. The skull of Lysorophus is slender, but not long; rather more like an Amphisbænian or a Cæcilian than a snake. The vertebral column is long, and is always found more or less perfectly coiled, a condition which led Baur to suggest that they might be embryos. This is hardly possible, because of the well-ossified condition of the vertebræ and the skull, and is not accepted, so far as I know, by any writer upon this animal.

If the creature did have limbs, they were very small and practically useless. If not snake-like, it was shaped like Proteus or Amphiuma, and was very probably similar to them in habits (Williston). The skeletons are found in great numbers in very limited localities, suggesting the gathering together of large numbers of individuals in slowly drying pools, which in their slow contraction forced the creatures together in large numbers in the

\footnotetext{
Dean, Proc. Zool. Soc. London, 1906, p. 172.
} 
last of the water. The fact that the bones are found in nodular concretions or limy clay gives support to this idea of desiccation and the concentration of the lime salts in the water. Associated with the skeletons of Lysorophus are the skulls of Gymnarthrus, Cardiocephalus (?), and the form called by Broili Diplocaulus pusillus, but they are not at all common. No bones of larger animals have been found with those of Lysorophus in Texas. It is probable that all the creatures that could do so escaped from the drying pools, but that Lysorophus, either because of its inability to leave the water or because it sought protection by burrowing in the mud, perished in the complete desiccation. If this idea seems probable, it may be accepted as confirmation of the amphibian nature of Lysorophus, for if it were a reptile it would have been far easier for it to escape from such surroundings.

No skeleton recovered is sufficiently complete to warrant an exact estimate of the length, but it certainly was not greater than 25 to 30 centimeters.

The author recognizes that Lysorophus is primitive in many respects, but regards it as far too specialized to occupy the ancestral position assigned to it by Broili, and thinks of it rather as a very highly adapted member of a primitive group, a terminal member of a side-line of evolution.

Crossotelos.-This genus has been found only in a single locality, Orlando, Oklahoma, but occurs there in considerable numbers. It is possible that the individuals suffered a fate similar to that of the members of the genus Lysorophus. Far too little is known of the skeleton (only a part of the vertebral column and a few limb bones) to enable any full idea of the shape or size to be formed. It had a long tail, expanded in the vertical plane, and was consequently a good swimmer. The limbs were of fair size. The chief peculiarity of this genus is the development of large, thin dorsal and ventral processes on the caudal vertebræ, and the closely inosculating, serrate spinal processes of the dorsal vertebræ. These structures are only matched in Osteocephalus from the Linton beds, upper Pennsylvanian, of Ohio, Keraterpeton from the Upper Carboniferous of Ireland (Scincosaurus from the Permian of Bohemia), and Urocordylus and Kcraterpeton from the Permian of Bohemia. This resemblance may be due to parallel evolution, but if so it is a very remarkable case. Osteocephalus was elongate and snake-like in form, and Keraterpeton was, as restored by Fritsch, a long-bodied, short-legged form, with a short, round head, and a tail longer than the presacral portion of the body. It is probable that Crossotelos was not very different from the last-mentioned genus in shape.

Cricotus (plate 20, fig. I).- This genus is the only known form from the Permo-Carboniferous fauna which can be considered as having adopted an active, predaceous, largely aquatic habit of life. The long and slender body, terminating in a long tail with elongate chevrons and spinous processes, the short limbs, with poor articular surfaces, and the elongate skull, with numerous sharp, grasping teeth, all remind us strongly of the essentially aquatic reptiles. 
The large chevron bones and the elongate neural spines of the caudal vertebræ show that the tail was expanded vertically, and was a most efficient organ of propulsion. What effect the embolomerous condition of the vertebræ may have had upon the strength of the vertebral column we can not say, but certainly it can not be regarded as a weak structure. The edges of the faces of the deeply biconcave vertebral disks meet upon a plane and would permit little lateral motion of the column, if there were not a considerable mass of inter- and intra- (between the central and intercentral disks) vertebral cartilage. If this were lacking, and certainly the disks seem very closely set together in the few series known, the body would have been more or less stiff, like that of an Icthyosaur or a modern dolphin; but if, as seems more natural, there was a considerable mass of cartilage, the body would have had great flexibility.

The animal probably moved with great swiftness, dashing upon fish and smaller creatures, and seizing them in its powerful elongate jaws. A recently discovered jaw indicates that the teeth were very small and recurved.

The partially complete skeletons in the American Museum of Natural History are from 30 to 40 centimeters in length, but the larger species must have reached a length at least twice as great.

In the recently discovered Brier Creek Bone Bed in Archer County, Texas, great numbers of Cricotus vertebræ were found in association with a fauna largely terrestrial, Dimetrodon, Edaphosaurus, Bolosaurus, Eryops, and a few small amphibians, but no traces of sharks or fishes. If Cricotus was largely aquatic in habit, as is indicated by its structure, this association is difficult to explain.

Chenoprosopus.- Though this form is known only from the incomplete skull, the shape of the head is so similar to that of Cricotus that we may be fairly certain that it resembled it in the rest of the body, and occupied the same position in the waters over what is now New Mexico in Permo-Carboniferous time as did Cricotus in the more eastern region. It is perhaps significant that the skull of Chenoprosopus was found in a deposit of river sandstones and that no vertebræ at all resembling those of Cricotus were found in the immediately adjacent bone beds which were formed in the quiet waters of a pool. Were Chenoprosopus, and perhaps Cricotus, members of a group which normally lived in large bodies of water, but which more or less frequently ascended the streams in search of prey, occasionally dying in places rather outside of their normal habitat, and leaving their remains among those of a fauna to which they did not normally belong? If so, they give us a glimpse of an open-water fauna of which we have no other knowledge, unless it be the radically different Stereosternum and Mesosaurus of the southern hemisphere.

Meh1 ${ }^{\text {a }}$ has compared Chenoprosopus with Cacops and Archegosaurus, and points out many resemblances. He is inclined to believe that the animal was perhaps terrestrial, because of the lateral position of the orbits and the crush- 
ing-teeth upon the palate adapted to the mastication of insect larvæ and small crustaceans. A lateral position of the orbits is not necessarily indicative of terrestrial life, as is shown by their position in the Plesiosaurs, Icthyosaurs, etc. However, far too little is as yet known of this New Mexican form to warrant extended speculation on its habits or form.

\section{REPTILIA.}

\section{Cotylosauria.}

Diadectes (plate 20, fig. 3, $a$ and b).-This genus is representative of a considerable number of less well known forms which were probably similar in habits and in the shape of the body. Bolbodon, Chilonyx, Diadectoides, Bathyglyptus (?), and Desmatodon were all diadectid animals, but any attempt at a restoration of any one of these must await further discoveries.

Diadectes probably reached an extreme length of 2.5 to 3 meters. Only a few bones of the giant Diadectes maximus have been found, but that there was such a creature is known from vertebræ and limb bones. Diadectes phaseolinus, the best-known species, did not reach a length of more than 2 meters. The body was short and stout, with a tail equal in length to the rest of the body. The limbs were extraordinarily heavy, and the humerus especially very broad, with powerful muscular articulations. The limbs ended in wide, short feet, with stubby digits, terminating in broad nail-like claws. The pectoral girdle was very strong, the bones being closely articulated, but as a whole it was surprisingly narrow. From the spread of the ribs and the general strength of the body, it might be expected that the fore-quarters would be broad, but this is not the case; the fore-quarters were decidedly narrow. The heavy head, with its large, lateral eyes and large auditory openings covered by a tympanic membrane, was set so close to the body that there was apparently no neck. In restoring the skeleton of the animal, it was found difficult to so arrange the bones that when the scapula was placed at what seemed the most posterior point possible the angle of the lower jaws would be free. The armor was confined to the anterior part of the thorax, unless, indeed, there was a row of dermal plates upon the back, as suggested above.

It is impossible to escape the idea that the animal was a very efficient excavator, and though Williston has shown that it would be impossible or very inconvenient for it to excavate a burrow, it might still have made use of its powers in procuring a food-supply of roots or burrowing animals.

Diadectes was a sluggish, harmless creature, dependent upon its imperfect armor or upon concealment for protection. It moved with a sprawling gait, the limbs standing well out from the body, which rested upon the ground. There is no doubt that it could raise itself slightly from the ground, but it was not possible for it to bring the limbs underneath the body, and walk or run. As suggested previously by the author (Carnegie Inst. Wash. Pub. I45), it must have resembled to some degree the modern Heloderma, especially 
if the claws of that lizard were made more nail-like, and the tail more slender and compressed vertically. It probably lived on the banks of streams, or in the thick vegetation, seeking its food along water-courses or in damp spots, and finding the vegetation a protection against the larger carnivorous reptiles. The large eyes and the enormous, probably functional, pineal eye have led to the suggestion that it may have been crepuscular in habit, with considerable powers of nocturnal vision, and came from its place of concealment only when the shades of evening were dense enough to protect it.

The more the author studies the anatomy and probable habits of this creature, the more he is impressed with the probability of his previous suggestion that it was in many respects similar to the modern swamp and land turtles.

Diadectoides was almost a travesty upon Diadectes. All the features of strength and stoutness were exaggerated to a great degree. Its specific name, cretin, was suggested by the dwarfish, overpowerful appearance of the imperfect skeleton.

Chilonyx had begun to develop a tuberculate condition of the skull like that of the Pariesaurus of Russia or Elginia of the Scottish Trias. Bathyglyptus apparently was of the same type, but is so little known that no suggestion as to its size or form can be hazarded.

Animasaurus and Diasparactus. - These animals from the New Mexican deposits were probably very similar to Diadectes in external form. Only the skull of Animasaurus is known. The exact form of the teeth has not been made out in either, but the shape of the roots shows that they were similar to those of Diadectes in a general way, and so indicate similar habits and foodsupply. They took the place in the New Mexican region that Diadectes occupied in Texas. The possibility that Diasparactus was more primitive than Diadectes is suggested by the fact that it has longer dorsal spines, with no indication of a possible dermal armor of ossicles.

Limnoscelis (fig. 20). - This animal shows relations both to Diadectes and Labidosaurus, as suggested by Williston. The form of the body and the stout limbs were like those of Diadectes, but the shape of the head, the position of the orbits and nares, the small pineal foramen, and the dentition composed of conical teeth, with enlarged incisors in the upper jaw, are decidedly reminiscent of Labidosaurus. As shown above, in the discussion of the food habits and the aquatic adaptations, the animal was a dweller in the water. Perhaps it was an aquatic branch of the same stem from which the terrestrial diadectids rose. The structure of the vertebral column, the limb bones, and the girdles are so similar in the two that we can not doubt that they had a common ancestry. The modifications in the head, dentition, and feet are all directly attributable to the adoption of an aquatic habitat.

The animal was about the same size as Diadectes phaseolinus, or a goodsized Eryops, and resembled the latter in habits much more than the former. The broad paddle-feet enabled it to swim rapidly and easily, and it could lie 
concealed in the water, with only the nose and eyes exposed, as deeply as any Eryops. It is possible that the great incisors were used, as has been suggested for Labidosaurus, to excavate burrowing animals or detach clinging molluscs. If this were true the animal would not have ranked with Eryops as a predaceous form. Its main defense was its ability to take to the water freely, if

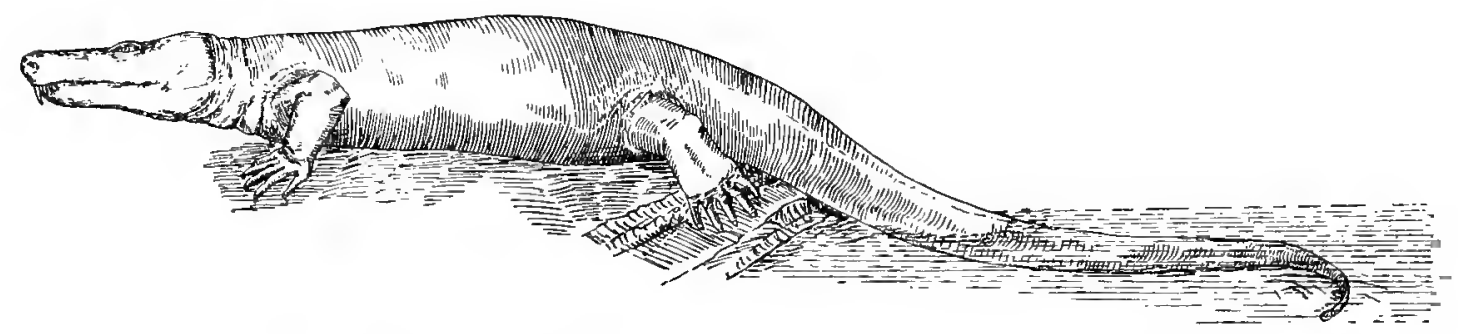

FIG. 20.--Restoration of Limnoscelis paludis Williston. About one-tenth natural size.

attacked upon the land, or in its rapidity of motion if attacked in the water. The great incisor teeth would have been no mean weapons if the creature was driven to the use of them.

Bolosaurus. - This was a small form, not over 30 to 40 centimeters in length. From the imperfect skulls and associated limb bones and vertebræ, it appears to have been a cotylosaurian, with a rather slender body, a long tail, and rather moderately long ribs. The teeth resemble those of Diadectes closely enough to suggest that it fed upon insects and small crustaceans and molluscs with weak shells. As noted above, Broom has suggested that Bolosaurus is not related to Diadectes.

Pariotichus, Isodectes, Ectocynodon.--These, with probably many other related forms as yet undiscovered, were small lizard-like creatures which lived in the thick vegetation, or hid among the rocks to escape the larger carnivorous forms.

Captorhinus (fig. 2I). - This genus was very rich in individuals in Clear Fork time. It reached a foot or more in length, including the not very long tail. The head was large in proportion to the body, the limbs well formed and terminating in strong feet with fairly long digits. It was active, and

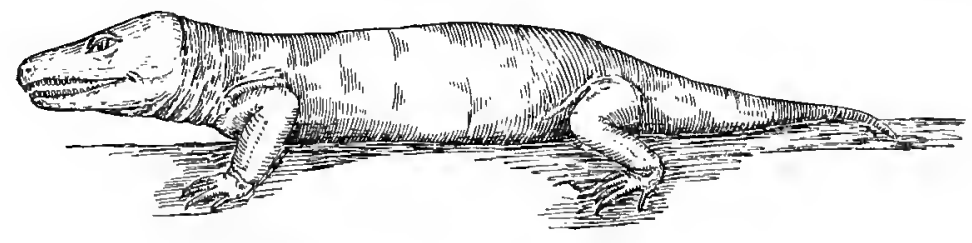

FIG. 21.-Restoration of Caplorhinus sp. About one-third natural size.

probably able to move with considerable rapidity for a short distance. The position of the orbits and nares and the well-developed articulations of the limb bones show that they were terrestrial in habit. Either upon the shores or in the damp places of the land, they sought the small invertebrates, including hard-shelled forms, upon which they fed. 
Labidosaurus (fig. 22).-This animal shows somewhat the same relations to Captorhinus that Limnoscelis does to Diadectes. It was a more aquatic form, with a flatter skull, having the orbit and nares near the upper surface. The teeth were far better formed and the carpus and tarsus better ossified than were those of Limnoscelis. The tail was only moderately long. It is probable that Labidosaurus was equally at home on the land and in the water, but not capable of very rapid movement in either. Upon the land it must

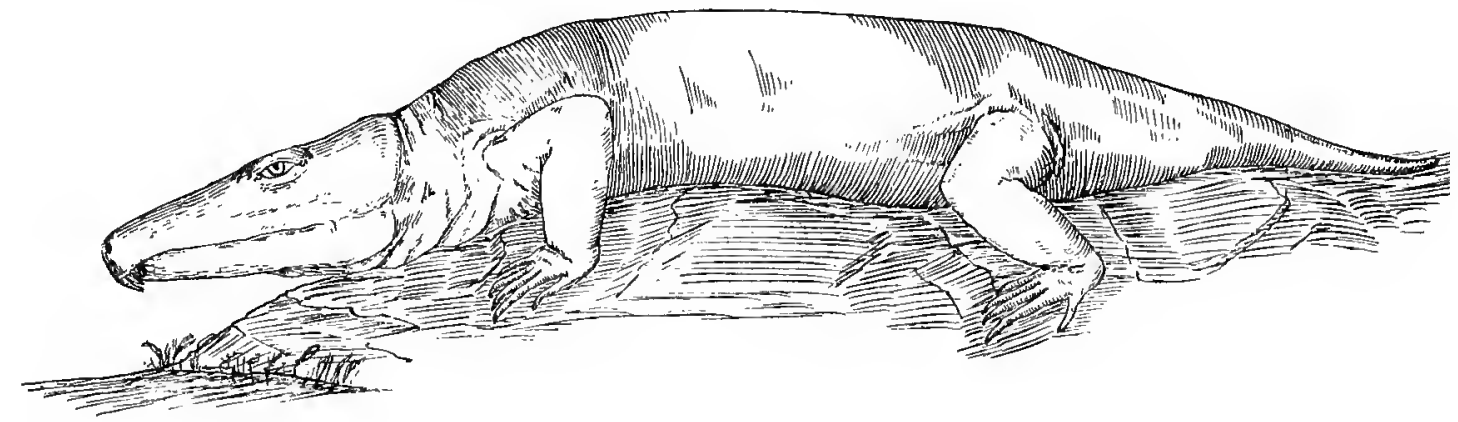

FIG. 22.-Restoration of Labidosaurus hamatus Cope. About one-third natura size.

have occupied a prone position most of the time, and probably never rose to a position so erect as given to it in Broili's reconstruction. The remains most commonly found indicate an animal of a meter or less in length, but a few skulls have been found which belonged to animals nearly twice that size. As suggested in the discussion of the food habits, it probably fed upon softer or less well protected animals than did Captorhinus. The incisors were too sharply turned backward to have ever been useful as weapons of offense or defense, but would have been very efficient in extracting burrowing creatures, or those hidden in cracks or crevices in the rocks, or tearing loose clinging forms. Labidosaurus was one of the great group which clung to the margin of the pools, or lived in the damp places among an abundant vegetation.

Seymouria (fig. 23).-This is one of the most puzzling of the PermoCarboniferous reptiles. It is so primitive in many of the characters of the

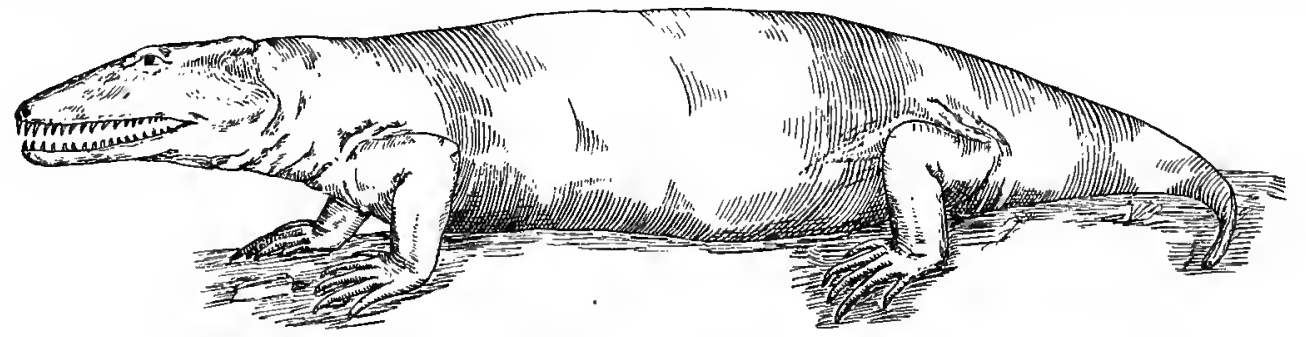

Fig. 23.-Restoration of Seymouria baylorensis Broili. About one-fourth natural size.

skull and skeleton that it is considered by Williston to be the nearest discovered form to the connecting-link between the reptiles and amphibians. The body was fairly plump, with strong limbs and rather slender digits, the tail being relatively short. Williston detected certain flakes of bone scattered through the matrix immediately adjacent to the bones, which he thinks are 
possibly the remains of dermal scutes, but no abdominal ribs have been detected, and he is certain that there were none. The movements were slow and sluggish, probably similar to those of a land salamander. The "long and slender teeth were utterly useless for the seizure and retention of large prey. I think it very probable indeed that its food consisted in a large part, probably wholly, of the smaller invertebrates, cockroaches, land molluscs, worms, etc." (Williston.)

Seeking protection and food in the deep vegetation, Seymouria was subject to attack from carnivorous forms, which would, as suggested for other forms, grasp at it from above. This is, perhaps, the reason for the great development of the neural arches, which, as Williston remarks, "form almost a carapacial protection for the body."

\section{PANTYlosauria.}

Pantylus.-Nothing can be said of the form or size of this creature. The skull alone is known, but served to show the presence in the fauna of a typical, durophagous (conchifragous) animal.

\section{Pelycosauria.}

Varanosaurus and Varanoops (fig. 24).-This is the best known of a group of long, slender, probably semi-aquatic, lizard-like reptiles, with many points in their structure which ally them with the Proterosaurida. The skull

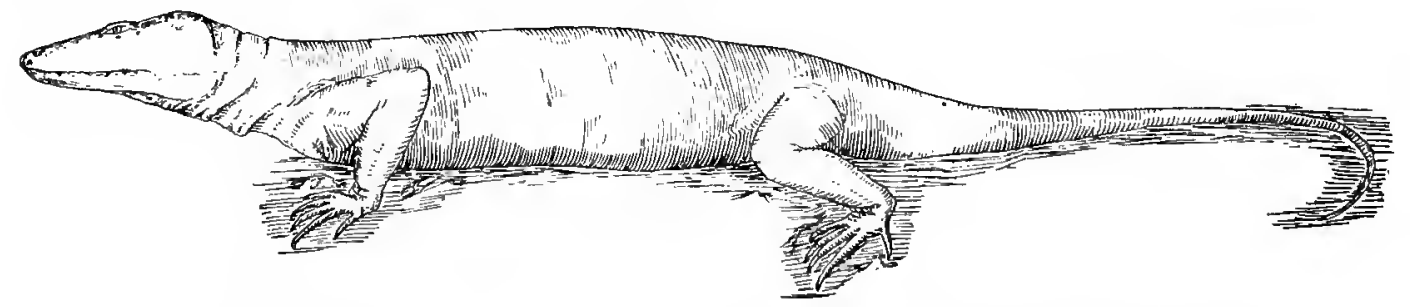

FIG. 24.--Restoration of Varanoops brevirostris Williston. About one-seventh natural size.

was more or less elongate, with sharp, conical, nearly isodont teeth. The limbs and feet were well formed and fairly long, the carpus and tarsus well ossified, the tail long and slender. They were probably able to move almost equally well on land or in the water, and there is a suggestion of agility which permits us to imagine them slipping with great speed through the underbrush, as they sought their prey, or escaped from larger forms. With equal ease and speed they may have glided into the pools or rivers, pursued or pursuing, and flashed through the water as would a modern Varanus. Paleohatteria, the nearest ally among the Proterosauria, was far more clumsy in its build, with much more cartilage in its joints and with weak feet.

Varanosaurus reached a length of a meter or more, and Pxcilospondylus was about the same size. Theropleura and Poliosaurus reached a greater length, perhaps as much as 2 meters.

In New Mexico there were very similar, but generally distinguishable, forms-Ophiacodon, Elcabrosaurus, and the creature originally described as 
Dimetrodon navajovicus, but which certainly does not belong to that genus, and has been called Arribasaurus. ${ }^{a}$

Ophiacodon (fig. 25). - This creature is known from an almost complete skeleton. The head was much more elevated in the facial region than in the related Texas forms, approaching in that respect the genera Clepsydrops and Dimetrodon from Texas. The peculiarly narrow skull, with the high and long facial region, and eyes far up on the sides and near the posterior end, was set at such an angle to the vertebral column that it was probably held rather high. The teeth were sharp, compressed cones, with cutting edges, but nearly isodont. The body was slender, with a tail as long as the body, and strong

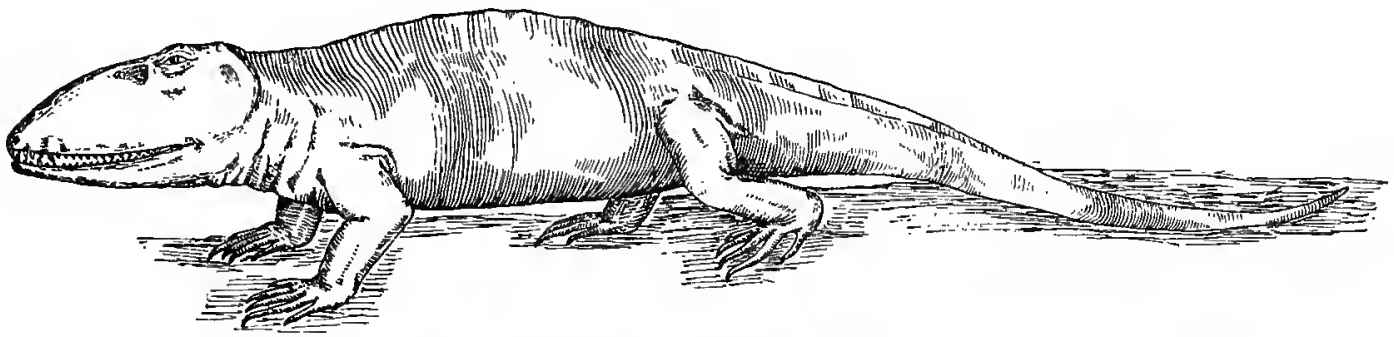

FIG. 25.-Restoration of Ophiacodon mirus Marsh. About one-seventh natural size.

limbs. The neural spines of the dorsal vertebræ are somewhat elongated, indicating the presence of a not very pronounced dorsal crest, as is suggested in the restoration. The caudal vertebræ were without high spines or long chevrons, indicating that the tail was cylindrical in form, and not of much use in swimming. Probably the animal was more terrestrial than its relatives in Texas. The total length of the single well-preserved skeleton is, as mounted in the University of Chicago, about I meter; this includes the tail, which is partly restored.

Theropleura (fig. 26).-Much like Varanosaurus in most characters, Theropleura was larger and stronger than that genus, with broader and heavier

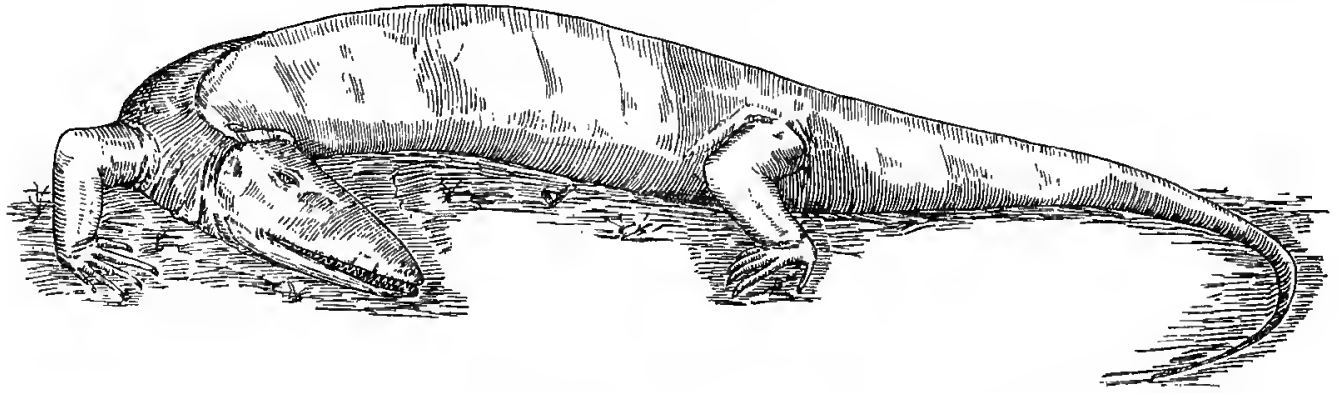

FIG. 26.-Restoration of Theropleura retroversa Cope. About one-tenth natural size.

limb bones. The dentition shows an approach to that of Clepsydrops and Dimetrodon in the beginning of enlarged incisors and maxillary tusks. The animal was evidently able to attack and hold active and vigorous creatures, which it encountered, in all probability, in the water. One suspects that when 
a Varanosaurus, or one of its kind, fled into the water to escape some prowling Dimetrodon, it was in considerable danger of being devoured by its relative, Theropleura.

Sphenacodon.-From New Mexico came the scant remains of an animal so like Dimetrodon in the structure of the skull that with the material at hand it is impossible to distinguish the two genera by any cranial characters. The dentition is in every respect the same, even to the enlarged incisors and maxillary tusks, but as no vertebræ of this animal have been found with dorsal spines more than 20 to 30 centimeters in length, it is apparent that Sphenacodon, while as active and fiercely carnivorous as Dimetrodon, lacked the high dorsal fin. Perhaps it was even more to be dreaded by other animals, for the dorsal fin of Dimetrodon was most probably a serious hindrance to rapid motion through the brush or high vegetation. It is very possible that Sphenacodon, with dorsal spines just beginning to elongate, represents the most active and efficient stage of the line which culminated in Dimetrodon. The size of the animal is unknown, but one skull recovered is about the size of that of a Dimetrodon of nearly 2 meters in length.

Clepsydrops and Dimetrodon (figs. 27 and 28).- The line of the carnivorous, raptorial reptiles reached its greatest development in these two forms.

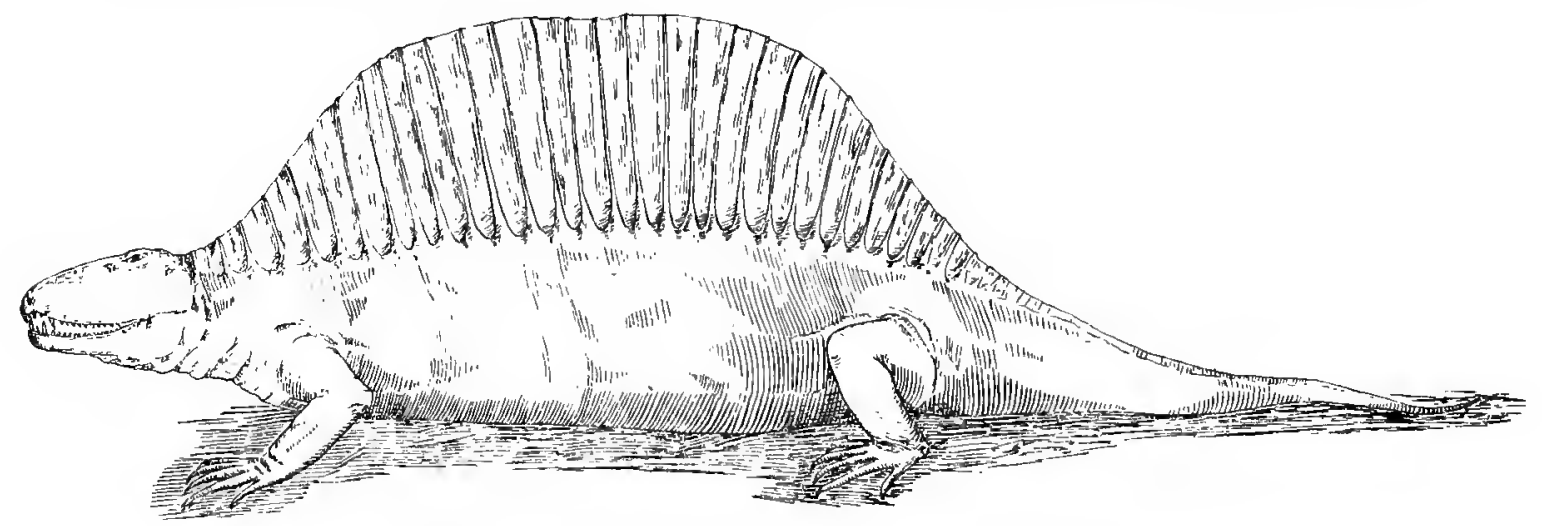

FIG. 27.-Restoration of Clepsydrops natalis Cope. About one-sixth natural size.

In describing the amphibians and reptiles, constant reference has been made to adaptations for defense, such as speed, agility, concealment, and armor. Although the nearly universal rule of the fauna was to eat and be eaten, it is probable that Clepsydrops and Dimetrodon were the most destructive forms among the Permo-Carboniferous reptiles and probably the dominant cause for the assumption of armor in their contemporaries. Clepsydrops was the smaller and less specialized of the two. The grasping-teeth were shorter and weaker; the incisors of the lower jaw did not lock so strongly between the premaxillary and maxillary tusks; the limbs were fairly long, but not so strong or well articulated as in Dimetrodon; the dorsal fin was not so high. The weaker articulations have led to the suggestions that the animal was aquatic in habit, but this is, at least, doubtful. 
The skull was high and narrow, with a large facial region, and eyes far back in the skull; the body probably rather slender, and the tail long. The extreme length was probably somewhere near a meter or a meter and a half. The animal probably haunted the banks of pools and streams, or stole through the vegetation, watching its opportunity to pounce upon some helpless or unsuspecting prey.

In Dimetrodon the characters exhibited in Clepsydrops are developed to the extreme. The morphological stages of development up to this highly predaceous reptile are probably represented by Theropleura, Sphenacodon, and Clepsydrops. The most primitive of the active carnivores were isodont reptiles

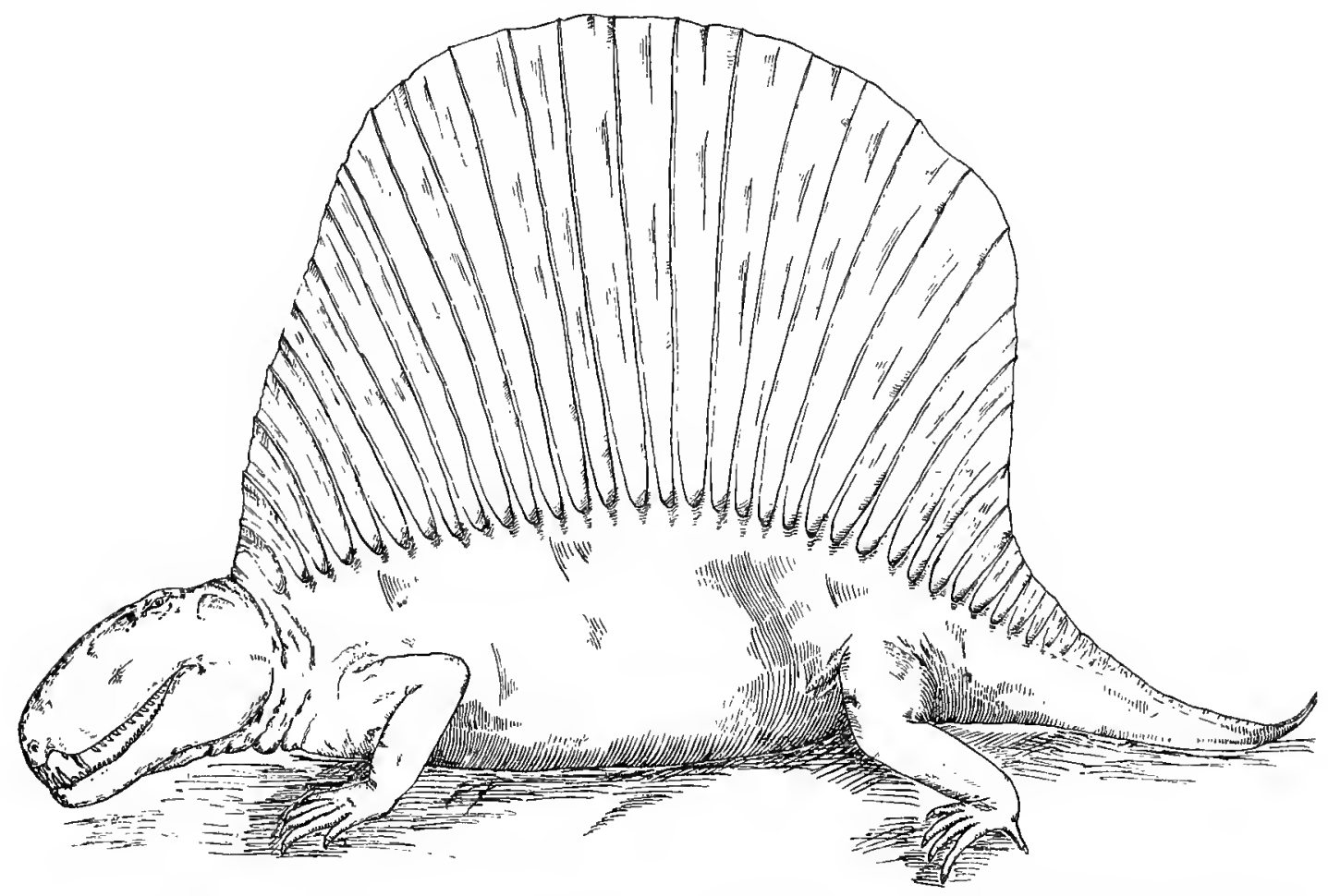

FIG. 28.-Restoration of Dimetrodon incisivus Cope. About one-fifteenth natural size of an average specimen. The back of the animal in the picture seems to be a little too much curved, but is modeled after the nearly complete specimen in the American Museum of Natural History.

like Poliosaurus and Varanosaurus, but as the necessity for seizing and holding an active, struggling prey became greater, the powerful incisor and maxillary tusks were developed, and the cheek-teeth of the skull and jaws became recurved, with sharp, serrate edges. There is no animal known, recent or fossil, in which a more efficient apparatus for such cruel business has been developed.

With the increasing strength and size of the genus Dimetrodon, the limb bones and feet became stronger and better developed. The animal probably abandoned the aquatic habits of its ancestors and ranged very widely over the land. As is apparent from the foregoing descriptions, the edges of the pools were probably the regions most densely inhabited by amphibians and reptiles, and no doubt such places were favorite haunts of the Dimetrodon. 
The strong limbs, with longer foreleg than upper leg, and the strong feet, with powerful claws, are ample evidence of an ability to run with some speed and perhaps even leap or pounce upon prey. Abel, in his Paleobiologie, points out that running and leaping animals have the foreleg longer than the upper leg, and creeping animals have the proportions reversed. It is not probable that Dimetrodon was ever capable of leaping any distance, but it certainly was able to move swiftly for a short space. Probably it lay hidden in the vegetation, and made short, scuttling rushes upon its prey, ending, possibly, with a short pounce, which permitted its weight to add something to the vigor of the attack by tooth and claw.

Several efforts have been made to restore Dimetrodon, but it has always been difficult to make an illustration of the dorsal crest which appears at all probable. That it was a thin, high fin, with the elongate spinous processes united by a thin membrane of skin, I have little doubt. Abel and Jaekel are disposed to think that the spines were covered by a skin, but not connected. To the author this seems highly improbable. Aside from the possible evidence furnished by the condition of Chameleo cristatus, ${ }^{\text {a }}$ there is little possibility that such weak structures could long survive serious breakages without the support of mutual connection.

The elongate spines were useless, so far as I can imagine, and I have been puzzling over them for several years. The probable cause of their great development is discussed upon a preceding page. It is impossible to conceive of them as useful either for defense or concealment, or in any other way than as a great burden to the creatures that bore them. They must have been a nuisance in getting through the vegetation, and a great drain upon the creature's vitality, both to develop them and to keep them in repair. The genus succeeded despite of them, or perished because of them.

The presence of several species and large numbers of individuals indicates that the genus was for a time at least successful, but this success probably resulted from a dominance attained before the dorsal fins reached their full size; from then on the spines became a burden and a possible cause of decline, as suggested above.

The most common species, D. incisivus, reached about 2 meters in length. No specimen has as yet been found with a complete tail, but the rapid decrease in size of the caudal vertebræ suggests only a moderate length. D. gigas, the largest known form, must have reached a length of at least 3 meters, and, probably, single individuals were even longer.

\section{EDAPHOSAURIA.}

Edaphosaurus (fig. 29).-No single animal of the Permo-Carboniferous fauna has been so much discussed or so greatly misinterpreted as this one. Because of the possession of elevated dorsal spines the skeleton was very naturally placed close to Dimetrodon, and it was restored with limbs, skull, 
etc., appropriate to that genus. The skull, long considered as belonging to a totally different type of animal, the scapula, pelvis, and the proportions of the limb bones have all been shown to be radically different from those of the Dimetrodon. The skull was rather short and high, with large orbits near the middle. The teeth upon the edges of the jaws are conical, with accessory crushing-teeth upon the palate and dentary. The scapula was very broad and heavy. An isolated scapula of this form was found many years ago by the author and supposed to belong to a diadectid, but, as has recently been

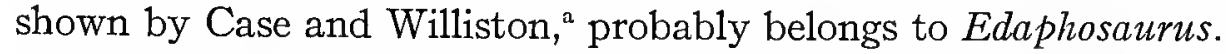

The limbs were shorter than in Dimetrodon, owing largely to the short fore limb, indicating a creeping habit and much slower motion. No foot bones have been certainly associated with this genus. A very large, claw-like

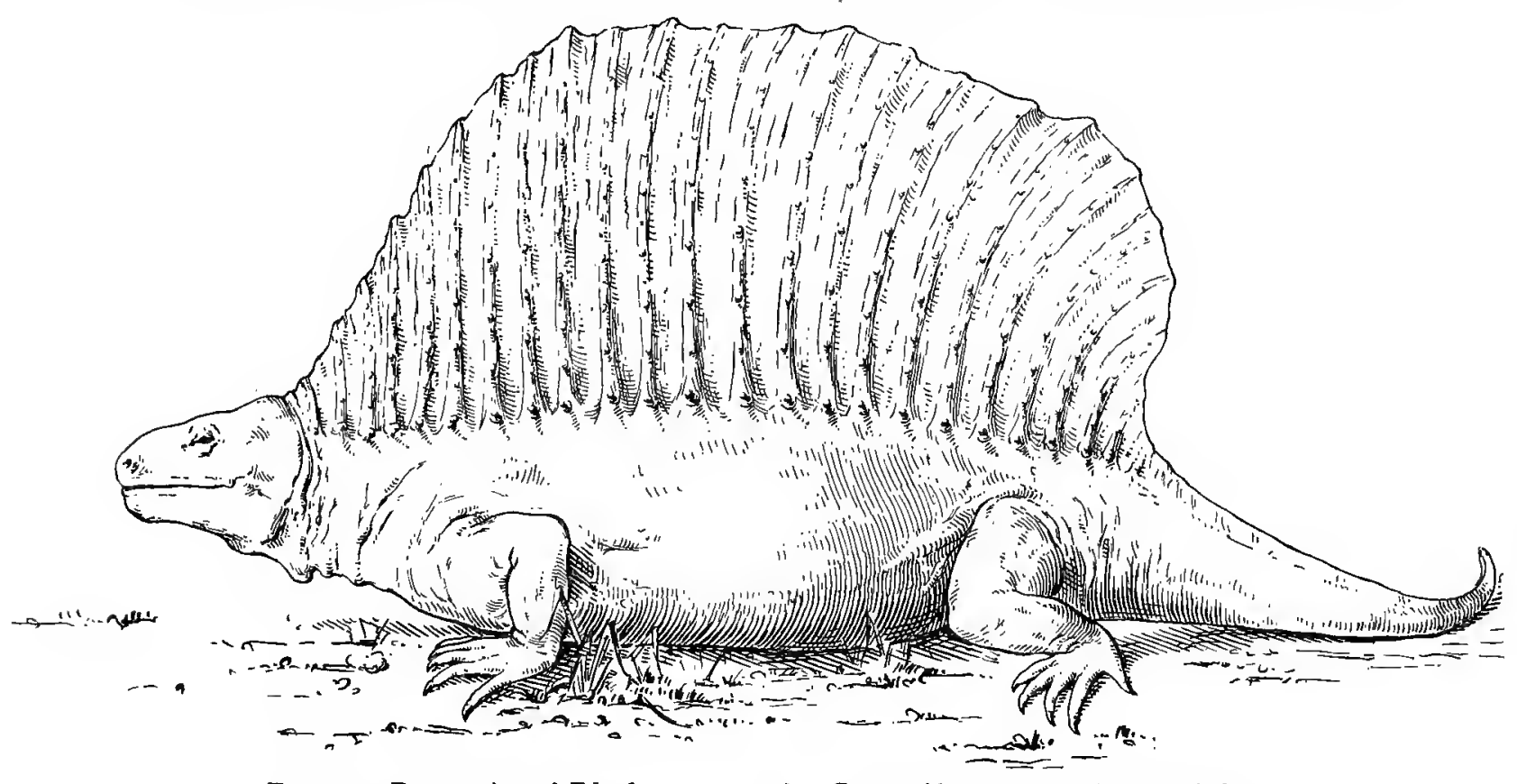

Fig. 29.--Restoration of Edaphosaurus cruciger Cope. About one-tenth natural size.

ungual phalanx is associated with a specimen in the American Museum, and well-modeled tarsal and carpal bones, not assignable to Dimetrodon or Diadectes, have been found in the Brier Creek bone-bed, associated with bones of Edaphosaurus, but the evidence is too unsatisfactory to be accepted without question. It is not improbable that the feet were strong, and provided with powerful scratching or digging claws.

The dorsal spines differed somewhat in the different species. In Edaphosaurus claviger the spines of the cervical vertebræ were expanded and clavate at the top; in Edaphosaurus cruciger they were very little or not at all expanded. The dorsal spines began immediately behind the skull, rose rapidly to their full height, and continued to the pelvic region, where they terminated abruptly. The spines of the first caudal vertebræ are abruptly reduced in 
height to a few centimeters, and lie beneath the spines of the sacral and posterior lumbar vertebræ, which curved abruptly backward. The length of the tail is unknown, but it was probably fairly long. The genus was rich in individuals and several species have been identified. The remains are not uncommon, but almost always consist of the fragments of spines, or complete isolated spines. This condition of the remains has been regarded as indicating that the animal's habitat was rather far from any place where the body could be easily embedded, and that it was disintegrated by carrion feeders, decay, or transportation for some distance, before burial.

Edaphosaurus was a slow-moving, harmless creature, feeding upon small invertebrates of all sorts and possibly vegetation. The powerful claws, if they belonged to this animal, would have been useful in digging in the soft earth or vegetation, or in tearing open decayed stumps and logs in search of insects, etc. If, as suggested, its habits confined it more to the upland, away from the waters and the abundant vegetation, it was perhaps beyond the ordinary range of the fierce carnivorous forms, and so found the peace and full nourishment which permitted the development of the enormous spines as a physiological excess.

The largest known specimens would have a length of about 2 meters, if we assume that the tail was as long as the rest of the body.

The single imperfect skeleton discovered in New Mexico, and described as Edaphosaurus novomexicanus, is, so far as it is known, very similar to those recovered from Texas. The imperfect skull shows the same form and the same arrangement of the teeth. The dorsal spines are more slender, with fewer and less well developed tubercules. Of the appendicular skeleton little is known. The conformation of the cervical vertebræ, as suggested by Williston, would permit the head to be thrown far down and even bent under the body, an attitude which would bring the anterior spines forward. If this is correct, it is the first hint of a use, defensive or otherwise, which has been found for the spines.

The single small fragment described as Edaphosaurus (Naosaurus) raymondi, from near Pittsburgh, is far too uncertain to use as a basis of any conclusion. It is not improbable, however, that Edaphosaurus ranged over the eastern United States, if, as supposed, it was an upland animal, and as its remains have been found in eastern Europe.

Platyhistrix.-In New Mexico there are found the remains of another long-spined creature, as yet but little known. The spines are shorter than those of Edaphosaurus, but are very large for the size of the vertebræ and very rugose upon the sides. The shape, size, and character of the skull and teeth are all unknown. We have here but a glimpse of another long-spined form which remains to be worked out.

Caseasauria.

Casea (fig. 30).-The head of this remarkable creature, as described and figured by Williston, was short and broad, with a flat or even slightly con- 
cave top, and a pineal opening even larger, proportionally, than in Diadectes. The large eyes were on the side of the head; the nostrils on the lower side of the blunt, projecting snout, and directed downward and forward. The body was quite broad, with well-developed ribs on nearly all of the presacral vertebræ. The limbs were strong, the anterior the longest, terminating in broad, stout feet. The tail was long and very slender. The teeth upon the edges of the jaws are few and blunt, leading Williston to the conclusion that it was phytophagous and moved slowly over the flat river plains, "perhaps feeding upon succulent meadow vegetation." Aside from the fact that a study of the possible food-supply does not afford any evidence of a suitable vegetation, the teeth seem to be fully as well adapted to a diet of soft or protected invertebrates.

The large eyes, enormous pineal foramen, and the well-developed sense of smell indicated by the large nasal cavities, together with the evident helplessness and lack of speed, suggest that the animal was dependent for its

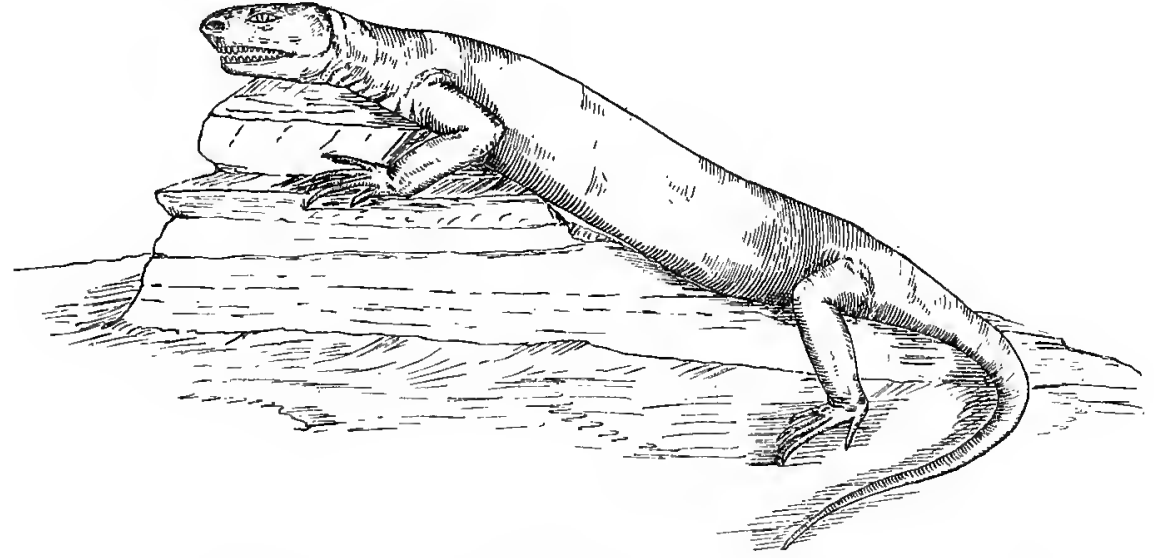

FIG. 30.-Restoration of Casea broilii Williston. About one-tenth natural size.

safety upon concealment, or nocturnal habits. Williston has also noted that the broad, squat body is such as commonly occurs in desert reptiles, and suggests that Casea may have lived in dry and heated localities.

Areoscelid $\approx$.

Areoscelis (fig. 3I).- -In the descriptions attempted above most of the animals have been found to be dwellers in the "lower jungle" or in the water. A few appear to have been dwellers on the higher lands. But a single genus, Areoscelis, has been recovered to show that there was a life of the "upper jungle." The remains described by Williston are those of an animal possessing extraordinarily light and slender bones. The skull and girdles are too imperfectly known to discuss, but the bones of the limbs are very long, hollow, and light, without evidence of the attachment of powerful muscles. In every way the skeleton suggests great speed and agility, equaling in this respect any living lizard. The bones are those of a swift terrestrial, or, more probably, arboreal creature. The branches of the great lycopods, or of the 
larger fern-like plants, probably formed its home, from which it descended to fly with lightning speed to some other place of refuge or to seek its food, which very possibly consisted, in part at least, of swift flying or crawling insects which the slower reptiles could not capture.

Williston estimates the length of Areoscelis at about 75 to 80 centimeters. Though this is the only known form supposed to have led an arboreal life, we can not doubt that there were many more whose remains we can never

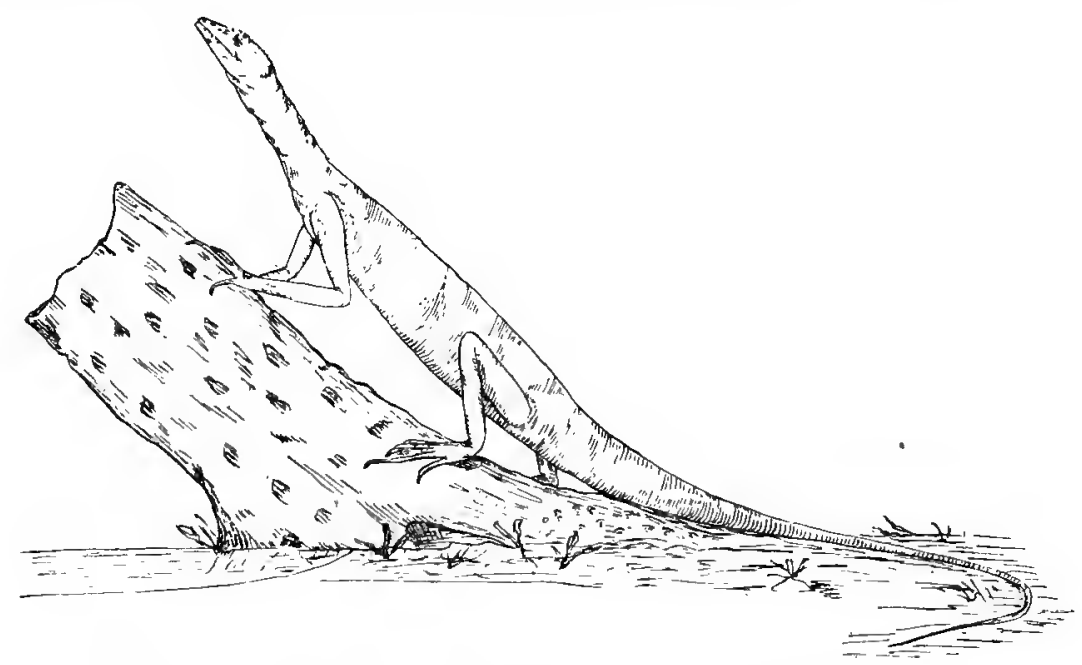

FIG. 31.-Areoscelis gracilis Williston. About one-seventh natural size.

hope to find, unless a few of them come to light, preserved by similar accidents to those which brought the bodies of a few individuals of the genus Areoscelis into the bone-bed where they were preserved. There was, in all probability, an abundance of terrestrial and arboreal life which will never be revealed to us. ${ }^{a}$

" Williston has very recently (Jour. Geol., vol. xxIr, No. 4, 1914) published a more complete description of Areoscelis, in which he asserts its relationship to the Lacertilia. "I have no hesitation in saying that the skull and skeleton of Areoscelis present distinctly primitive characters of the Squamata, to such an extent that I believe the genus has a definite phylogenetic relationship to the order." 


\section{RESTORATION OF THE REGION AND ENVIRONMENT IN WHICH THE ANIMALS LIVED.}

In the preceding descriptions only the better-known forms are included. Many more are known from incomplete skeletons, solitary bones, or fragments, which would not warrant any attempt at restoration. Probably many more forms will be discovered in the Permo-Carboniferous beds, but a large proportion of the fauna may never be known. Enough has already been made out to show that it was abundant and most complex.

Considering only the region in Texas and Oklahoma, which is typical of all the Red Beds, we may restore in imagination a great flat land stretching away from the Wichita Mountains and the Arbuckle Hills to the east and south, where it joined the ocean waters. The western border of the flat we do not know. The normally semiarid condition of the land was interrupted by incursions of the sea and fluctuations of the climate to more humid conditions. The aridity never attained a degree which prevented the growth of some vegetation or the presence of pools of water and running streams, but was sufficiently intense, at times, to prevent the accumulation of much vegetable débris in swamps or stagnant lagoons. In the times of increased humidity the vegetation increased in quantity, the waters accumulated in large areas and were overshadowed by a heavy growth, and the streams expanded and spread over their flood-plains, leaving masses of irregularly bedded sandstone and clay. It would perhaps express the ideas of the author a little better to speak of the great flat as being particularly well drained in the times of greatest aridity, with the water-table low, allowing a free circulation of water and air. In the more humid periods the water-table rose, and the circulation of the air and water was prevented. Even in the times of greatest aridity it must be supposed that there probably were seasonal or other changes of small period which brought enough moisture to keep the land far from a true desert condition.

Upon this flat, largely around the pools and streams, lived the wonderfully complex amphibian and reptilian life. The waters swarmed with fish and amphibians, and were constantly invaded by predaceous reptiles in search of food. In the quieter pools and back waters of the streams lurked the great Eryops and its lesser relatives, ever ready to rush from their concealment upon any unfortunate creatures that ventured too near. In the open waters of the stream Cricotus opposed its strength to the current, spending its time in active search and open attack upon its prey. Burrowing in the mud, or creeping slowly along the slime at the bottom of the water, were such forms as Lysorophus, Diplocaulus, and a host of forms with similar habits. The slender Varanosaurus or Theropleura slipped quietly into water and swam slowly until the sight of some victim caused it to leap into activity and follow its prey with lightning speed at the surface or beneath the waters. The banks of such pools and streams must have been arustle with the shifting, 
hiding, searching creatures. The harmless Dissorophus, Cacops, Seymouria, and diadectids scratched and grubbed among the leaves and in the soft earth after worms, larvæ, and small creatures of all kinds, or at the water's edge overturned stones and tore apart the rotting stumps of the great lycopods in the same search. Some of these forms were undoubtedly very sluggish and sought their food or endured their fate with an equal stolidity, but others were alert, and on the approach of some carnivorous reptiles there was a sudden dash for the water. Scrambling through the weeds, slipping from convenient logs or stones where they had been sunning themselves, seeking the deep water in the quickest way, the smaller creatures fled the larger ones.

The terror of those banks must have been the great Dimetrodon. With speed, power, and an armature of teeth far ahead of any creature of its time, its progress must have been one of devastation. Fearing only individuals of its own kind, the only need for care in its motion was to avoid disturbing the prey before it was sufficiently close to warrant the last dash. When once the great teeth had seized the animal there was no escape. Clepsydrops, in the water or always near it, and Dimetrodon, haunting the higher land or the water's edge, were the tigers of their time. There must have been some notable battles in those woods. The skeletons of Dimetrodon very frequently show the marks of fracture and healing in the slender spines, undoubtedly the results of sanguinary conflicts over victims or for mates.

On the higher lands, on the banks of the pools, perhaps even upon the shores of the invading seas, the diadectids, Edaphosaurus, and Pantylus sought the hard-shelled molluscs and other animals, or the vegetation which served them as food. That Diadectes, at least, was not free from attack, is shown by the beginnings of a defensive armor. Edaphosaurus, if the author's ideas are correct, had found some form of protection or isolation which permitted it to develop in comparative peace and safety.

Among the trees and bushes moved Areoscelis, undoubtedly with many accompanying forms of which we have no knowledge.

The composition of the complex fauna undoubtedly changed with the changing climate. Periods of drought would drive some of them out, or cause the death of large numbers which sought shelter in the desiccating pools. Recurring humidity brought back the life again. The passage of years also brought its changes. Forms familiar in the lower beds are absent above, and new forms come in. It is probable that this was, in part, due to the extinction of old forms and the evolution of new, but there can be no doubt that the conditions during Clear Fork time were decidedly different from those of the Wichita, and the altered composition of a fauna is as frequently the result of migrations as it is of evolution.

Another thing that must be constantly kept in mind is that the remains are not found in their natural habitat. In only a few cases can it be shown that the animals have been buried near where they lived or died. Rivers or currents in larger bodies of water have borne the carcasses away after death, 
and in any attempt to picture the natural habitat this must be reckoned with. The deposits in which the skeletons are found are not the same in form and composition as those among which the animals lived. The material has been transported at least as far as the skeletons and has suffered much alteration.

TABLE 3.-Showing forms in New Mexico and Texas which exhibit parallelism or relationship in structure and habits.

[Forms marked with a question mark (?) may later be recognized as distinct genera, but as yet there is insufficient evidence.]

\begin{tabular}{|c|c|c|c|}
\hline 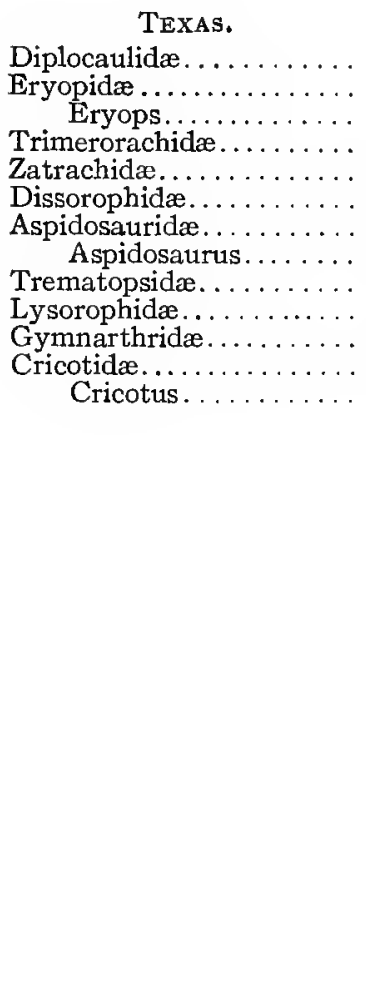 & 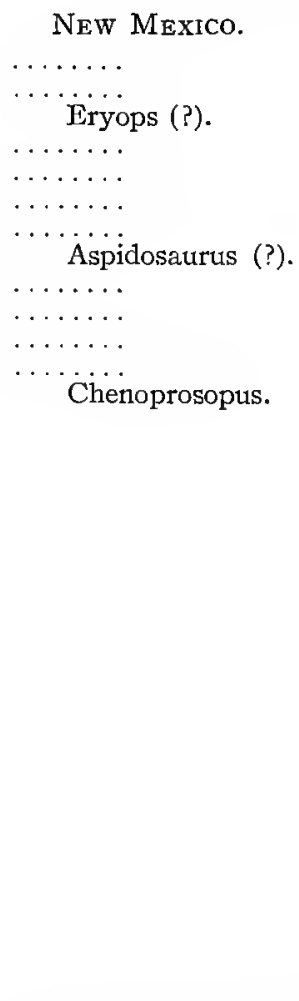 & 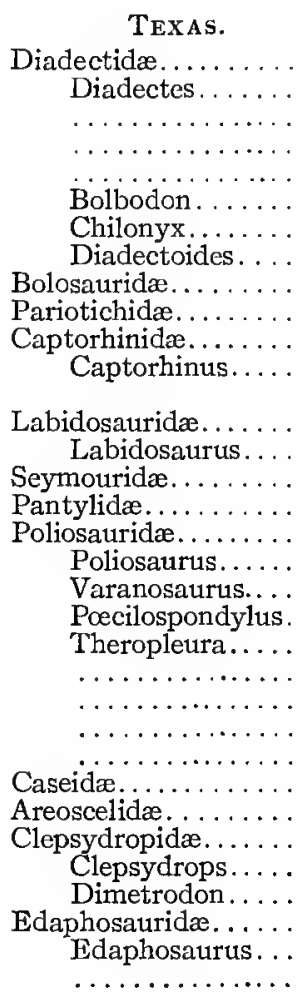 & 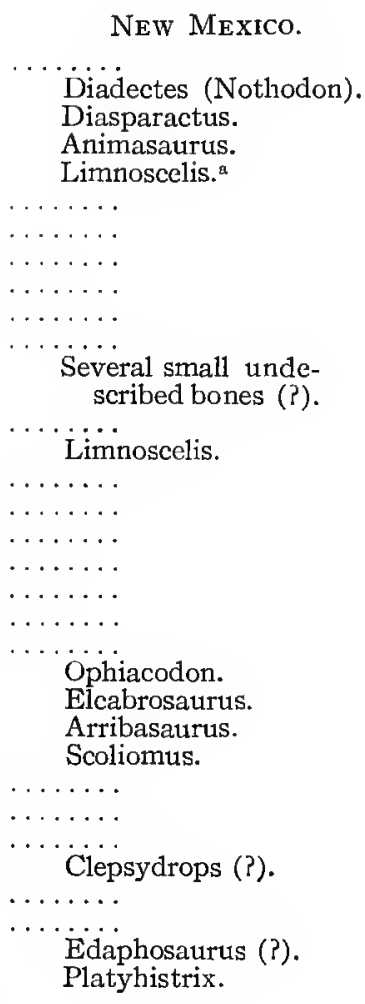 \\
\hline
\end{tabular}

a Limnoscelis may be nearer to Labidosaurus. 


\section{CHAPTER IX.}

\section{RELATION OF NORTH AMERICA TO THE OTHER CONTINENTS IN PERMO- CARBONIFEROUS TIME.}

The Permo-Carboniferous fauna has been traced from New Mexico to Prince Edward Island, but has not been recognized with any certainty in the European Permian, as shown by Case. ${ }^{a}$ The only European genus which has been recognized as belonging to the Texas fauna is Edaphosaurus, described by Fraas from Bohemia and by Jaekel from the vicinity of Berlin. ${ }^{b}$ Von Huene has described two forms, Anomosaurus and Ctenosaurus, which he considered as related to the Pelycosaurs, but which, occurring as they do in the middle and upper Triassic, can be regarded only as widely removed descendants, if related at all. ${ }^{\circ}$

The resemblance of Crossotelos to Urycordylus and Keraterpeton can not be considered as genetic.

The fauna of North America was, so far as the author can see, an isolated one, prevented from any mixture with other groups of animals by an isolation of the continent from Europe nearly as complete as that of to-day. The author is in accord with Williston in this matter, who in 1909 expressed himself concerning the fauna as found in Texas as follows: ${ }^{\mathrm{d}}$

"As a continent I believe that the land of America was absolutely and continuously isolated, so far as the intermigrations of land forms were concerned, from some time before the close of the Pennsylvanian till well into Triassic times, as they reckon in Europe.

"The fauna was literally sui generis, and I may almost say sui ordinis. But two or three genera of two types out of the scores of genera known from these regions can be correlated as showing resemblances-family resemblances, I meanwith foreign forms. And both of these types had made their appearance, admittedly nowhere in America, before the close of the Pennsylvanian, one the derivation of Upper Carboniferous, possibly sub-Carboniferous stock, the other a later development, and both continuing for a brief period in Europe during the Permian times. Of all the remainder of the air-breathers not one can be compared with forms known elsewhere in the world, save in general characters-ordinal characters at best.

"These facts can mean but one thing: the faunal isolation of land and freshwater vertebrates during all of the so-called Permian times in America. * **

"Upon the whole, then, our Permian fauna is sharply, and almost completely, distinguished from any supposed contemporaneous or indeed any fauna known elsewhere, and may have been evolved wholly in America from known Pennsylvanian forebears."

a Case, Jour. Geol., vol. xxvi, No. 6, pp. 572-580, 1908 .

b Jaekel, Naosaurus credneri, in Rothlicgenden v. Sachsen. Monatsb. d. Deutsch. Geol. Gesellsch., I910, Nos. 8-10, pp. 226-535.

- Described and discussed in Carnegie Inst. Wasl. Pub. 55, pp. 33-57.

d Williston, Jour. Geol., vol. I7, p. 389, 1909.

I50 
Whether there was as complete an isolation in the earlier stages, represented perhaps by the New Mexican fauna, the author is less certain. The similarity of the Poliosauride to the Proterosauria is so striking that a community of European and North American forms is suggested in the lowest Permo-Carboniferous or late Pennsylvanian. Edaphosaurus credneri is distinguished by Jaekel from later forms by the sparse projections upon the spines, a character also noticeable in Edaphosaurus novomexicanus from the New Mexican beds.

There are three possibilities of a connection between North America and the other continents: Either with the Europe-Asia continent by way of the North Atlantic continent; to the south with Gondwana land by way of a landmass where Central America now lies; or across the Bering Straits with Asia.

The possible connection with Europe-Asia will be first considered. Suess, Frech, De Lapparent, Neumeyer, and others have demonstrated the presence of a great east-west chain of folded mountains across France and Germany, reaching into southern England, Wales, and Ireland, which was uplifted in Carboniferous time, and again uplifted after profound degradation in Permian time. This is the great Hercynian chain, or Paleozoic Alps, composed of an eastern, Variscan, portion in Germany and southern Russia, and a western, Armorican, portion in France and Great Britain. The western ends of the Armorican folds end abruptly at the Atlantic borders, or disappear beneath it. On the opposite side of the Atlantic similar folds appear in Newfoundland, with equal abruptness, and are correlated with the Appalachian folds to the south. The sudden ending of the folds in a rias coast is accepted as evidence of their previous continuity across the ocean in the old North Atlantic continent which probably disappeared in the great movements of the Mesozoic.

The presence of a great North Atlantic continent in Carboniferous and earlier times is accepted as a proved fact by all the writers upon the subject, and need not be defended here. The reader will find discussions of the subject by the following authors:

De Launay, La Science Geologique (chap. XII, p. 500), speaking of the Stephanien, says:

“Enfin, aux Etats-Unis, des accumulations de végétaux se font également sur des côtes à l'Ouest des Appalaches dans 1'Illinois, 1'Arkansas, le Kansas; une châine, homologue de la chàine hercynienne et qui la prolonge peut-être, au Nord de notre Mer Intérieure, au Sud de notre grand sillon houiller, surgit dans les Appalaches."

On a map opposite page 498 De Launay gives his idea of the paleography of Westphalien time. In this he shows a land-mass occupying the whole North Atlantic area, and connecting Europe with North America.

In a map at the end of the book he shows the northern hemisphere, with indications of the Hercynian folds reaching far out into the Atlantic Ocean from both the eastern and western sides. 
Suess, in his Face of the Earth, volume II, page 97, gives an account of the rias coast of Brittany and Newfoundland, and on pages 201 and 202 of the same volume, a general account of the rias coasts of North America and Europe. On page 202 of volume II he gives in some detail the evidence, from the character and position of sedimentary beds, for a North Atlantic continent.

Frech, in the Lethea Paleozoica, volume II, page 402, with map $v$ in the accompanying atlas, describes the broad land-mass reaching from central France and southern England across the North Atlantic in Upper Carboniferous time. The statement is made both by Frech and Suess that the elevation of this land-mass had little or nothing to do with the various minor movements of the sea over Europe in Carboniferous and Permian time.

Arldt, in his work, Die Entwicklung der Kontinente und Ihrer Lebewelt, says, on page 577 :

"Im Perm sind die Altersbestimmungen verschiedener Schichten besonders der südlichen Hemisphäre noch zu unsicher, um die Rekonstruktion einer paläogeographischen Karte zu gestatten, die einigen Anspruch auf Richtigkeit hätte. Im unteren Perm hatte die Nordatlantis etwas dieselbe Ausdehnung wie im oberen Karbon, doch war das Davisbecken jedenfalls nach Süden noch etwas weiter ausgedehnt, so dass es mit dem nordatlantischen Becken durch eine schmale Meeresstrasse in verbindung trat und die Nearktis vollständig von der Nordatlantis abtrennte. Die Nearktis hatte sich westwärts etwas ausgedehnt, doch war Kalifornien noch Meeresgebiet. Nach Süden zu trat die Nearktis mit der Südatlantis in verbindung und schnitt so das nordaltlantische Meer von dem Grossen Ozeane ab."

And on page 575:

"Grossartig war der Gebirgsfaltungsprozess der in der Mitte der Karbonzeit einsetzte, wobei die Gebirge in der Hauptsache den Rändern der Kontinente folgen. Den Südrand der Nordatlantis bezeichnete das längste und bestbelkannte der damaligen Gebirge, das durch südnördlich gerichteten Druck an den Kontinent angeschoben wurde. Seine westlichen Spuren finden wir in den karbonischen Diskordanz des Felsengebirges. Weiterhin steigen die Appalachien empor und infolge dieser Hebung trat die oben erwähnte nordamerikanische Regression ein. Das Gebirge führte nun über den jetzigen Ozean und setzte sich in den aremorikanischen Ketten fort, die in Mittelfrankreich mit den variskischen zusammenscharten und durch ihre erhebung die Regression in Mitteleuropa bedingten."

While many other authors might be cited to prove the general consensus of opinion that such a continent existed, these works contain the collected evidence and seem sufficient.

Just what the condition of this continent was in Permian time seems less certain. As quoted above, Arldt believes that a southern extension of the Davis Strait cut across the North Atlantic land and separated the eastern and western land-masses.

Frech (Lethea Paleozoica, vol. II, p. 662) says that little can be said concerning the North Atlantic continent in the Permian. De Lapparent (vol. II, p. I025) mentions the occurrence of Schizodus sclotheimi and Aucella hausmani 
in Nova Scotia, and on page IoI 8 , in a map of the Thuringien, shows an arm of the sea reaching across from north of England to Nova Scotia. ${ }^{2}$

Koken (Festband der Neues Jahrbuch fur Mineralogie, Geologie u. Paleontologie, I907, p. 525) says that the Zechstein deposits of Nova Scotia (the locality of Schizodus and Aucella mentioned above) are outlying deposits of the Arctic Ocean. De Lapparent (according to Koken) would have the deposit connected with the Paleozoic Mediterranean (see the map of the Thuringien cited above), but this is not borne out by the fauna. There is a possibility, despite the lack of connecting sediments, that it was connected with the western American province. The decision must be made in the future. We may still be certain, in any case, of the presence of a North American-GreenlandNorth European land-mass.

From the foregoing citations it is apparent that the site of the North Atlantic Ocean was occupied in pre-Permian time by a great land-mass. The condition of the land in the Permian is uncertain, but there were possibly some breaks across it, as the Davis Strait, which would constitute a barrier to migrations between Europe and North America.

On the eastern land-mass the Hercynian chain completed its development before the Permian time, was eroded, and re-elevated in the Permian. On the western land, the Appalachian Mountains were not elevated until the later part of the Permian. If, as is probable, the Appalachians were elevated by a great world movement which was manifest earlier in Europe as the Hercynian chain (Armorican-Variscan) and progressed toward the west, it is probable that the North Atlantic continent carried the connecting link in the late Carboniferous and Permian. 'The ends of the links are seen in the rias coasts of Great Britain, France, and Newfoundland. That no remnants of the mountains are found by soundings in the North Atlantic is not surprising, for even if the great basin was formed in Mesozoic time, the previous exposure was sufficiently long to wear the mountains down to low altitude. Witness the reduction of the Appalachians to a peneplain condition by Jurassic or early Cretaceous time.

Either a break in the North Atlantic continent or the presence of high mountains would have been an efficient barrier to the migrations of the Permo-Carboniferous reptiles and amphibians, and either or both of these geographic features occurred in late Carboniferous or Permian time, on the land connection between Europe and North America, permitting the migration of the earlier Carboniferous or Permo-Carboniferous forms and isolating the later and more specialized forms.

The possibility of migration was again established in the Triassic, as shown by an abundance of common forms.

The possible connection with South America has been suggested by Broom, who believes that somewhere in that continent the common ancestors

a The author has been unable to trace the origin of the statement of De Lapparent. It may be taken from Geinitz, K. Leopold, Carolin. Acad., Bd. 33, I866.' 
of the African and North American faunas were developed, and that there was a dispersal of the fauna from a common center. Broom says:

"Taking all the facts into consideration, it seems to me probable that in Upper Carboniferous times there appeared in the northern part of South America a primitive land vertebrate fauna, comprising among other types temnospondylous amphibians, primitive cotylosaurians, and primitive ancestral Pelycosaurs. Before the conclusion of the Carboniferous period, this South American fauna invaded North America, and almost immediately afterwards the northern group became isolated. The isolation continued during at least the whole of the Lower Permian times, and these isolated types became greatly specialized in their struggle with some adverse conditions. What the conditions were we do not know, and no satisfactory explanation has, I think, been given of the development of the enormous spines of the vertebræ in the Pelycosaurs. Nor do we know what caused the extinction of the whole fauna about the Middle Permian times, but most likely some change in climatic conditions.

"In South Africa the first Karroo reptile to appear is Mesosaurus, which is found in beds a little above the Dwyka tillite. It is certainly generically similar to the Mesosaurus of Brazil, and closely allied specifically. This occurrence of Mesosaurus on both sides of the Atlantic, as well as a series of plants which are specifically identical in Brazil and South Africa, renders it practically certain that there was a land connection between South America and South Africa in Lower Permian times, and that animals might have migrated from what is now the one continent to the other. There is, however, no evidence that any reptiles other then Mesosaurus arrived in South Africa till some considerable time after the origin of the Permian. Perhaps the reason for this may be that about the beginning of the Permian period South Africa, and probably much of South America, Australia, and India were, from some cause or other, largely covered by glaciers, and possibly for long afterward the climate was too severe to allow the more northern or equatorial types to invade the south. In beds which are called Ecca we get the earliest immigrants-a large carnivorous reptile called Archeosuchus, which may have been a dinocephalian, and evidence from a tooth of a large undoubted dinocephalian which was a herbivore. It is, however, not till Middle Permian times that the fauna becomes rich. Then there appear pareiasaurians, a considerable variety of dinocephalians, many therocephalians, a few anomodonts, the only known dromasaurians, and a temnospondylous amphibian. Where this great collection of forms came from is, of course, unknown. They can hardly have originated in South Africa, because though the lower Permian beds are lithologically exactly similar to those of later Karoo times, they are almost entirely unfossiliferous.

"It seems to me, however, probable from the general resemblance of the African fauna to the North American Permian, that both have come from the common source, which I believe must have lived in the northern part of South America. After the invasion of North America in Upper Carboniferous times, all connection between North and South America ceased for a very long period. The near relatives of the ancestors of the North American Permian forms left in South America evolved on quite other lines. For long they were probably confined to the Brazilian region, owing to the cold prevailing in the South, but ultimately they spread down and across the South Atlantic into Africa, where they for the most part arrived during the Middle Permian times."

If such a connection, as supposed by Broom, existed between North and South America, it must have been in or before Pennsylvanian time. Deposits

a Broom, Bull. Amer. Mus. Nat. Hist., vol. xxviII, art. Xx, p. 233, I9ı。. 
of undivided Carboniferous are found in Nicaragua and Honduras, ${ }^{2}$ and rocks of Pennsylvanian ${ }^{b}$ and Mississipian age occur in Chiapas, Guatemala.

Koken, ${ }^{c}$ in his map of the Permian, shows the sea extending across the Central American area, apparently on the evidence of Fusilina found in British Honduras and Chiapas.

No Permian deposits have been found in Central America, but the Guadalupian fauna of Girty shows that there was a body of water over trans-Pecos Texas and a portion of southeastern New Mexico, in Permian time, which was connected with the European Permian seas. If the animals of this sea were derived, as is possible, from a Mediterranean Tethys, the isolation of North America from South America is certain and demonstrated. If, as Koken has suggested, the fauna reached the site of the Guadalupian Mountains through the Pacific rather than through a Mediterranean sea, there still remains the evidence of a sea across Central America in the Fusilinas of British Honduras and Chiapas.

It seems to me far more likely that the North American fauna originated in the northern land-mass, developing from some such forms as Sauravus costei Thevenin, from the Stephanien of France, and Eosauravus copei Williston, from the Linton coal-beds of Ohio, and spread freely in late Carboniferous time after a considerable evolution, such as is suggested by the fauna of the Pittsburgh shale. Of this fauna we have representatives in the specialized Proterosauria of Europe and the Poliosaurida of North America, probably in many of the amphibia of both continents, and even in Edaphosaurus of Saxony and Bohemia, Pennsylvania (?), and New Mexico. It is not probable that free communication across the North Atlantic continent was interrupted at the time the Pittsburgh shale was laid down, and the genus Edaphosaurus, or its immediate ancestor, was probably already in existence and had spread east and west.

Shortly after this stage the free passage across the North Atlantic continent was interrupted either by an arm of the sea (the southern extension of the Davis Strait) or by the elevation of the Hercynian chain on the North Atlantic continent. This isolated a fauna in North America which, developing by itself, resulted in the assemblages found in the Texas, Oklahoma, Kansas, Illinois, and Prince Edward Island beds.

For the third possible connection we have no evidence from vertebrate fossils. It is suggested by White ${ }^{\mathrm{d}}$ that the fern Gigantopteris may have reached North America by this route.

THE FATE OF THE AMERICAN FAUNA.

The North American fauna developed per se, and apparently disappeared before the beginning of the Triassic. It is very evident why some forms should have so disappeared, for they had reached a degree of specialization

a Willis, U. S. Geological Survey, Professional Paper 7I, p. 345.

b Willis, ibid., p. 425. (Report of Sapper's work.)

- Koken, Festband d. Neues Jahrb. für G. M. u P., 1907, Tafel xIx.

${ }^{d}$ White, David, Proc. U. S. Nat'1 Mus., vol. 4I, p. 5I I et seq., I9I2. 
which could not endure even a slight change of environment. What the change was it is difficult to say. The Red Bed conditions were apparently continued unchanged into the Triassic. On Poleo Creek, in Rio Arriba County, New Mexico, the author secured a section of a bluff 800 feet high. ${ }^{2}$ The lower 400 feet or so carried Permo-Carboniferous vertebrates, the upper Ioo feet Triassic vertebrates; the intervening beds were barren, but with absolutely no indication of a change in the nature of sedimentation or climate. Only at the top of the bluff, above the lowest Triassic fossils, was there a difference in the color and character of the beds. This is typical of the conditions over most of North America. In some places, as in western Texas, there is a general difference in the structure, beds, color, and character of the clays and sands, but no great unconformity or evidence of pronounced change. What caused the extinction or displacement of the fauna we can not sayperhaps some slight climatic change, or change in surface, elevation, humidity, or food-supply. Any of these would have been sufficient.

That the North American fauna, or close relatives of some of its members, existed in Europe, in a somewhat modified form, after it had become extinct in the western hemisphere there can be no doubt. This relation between the faunas is, however, a question too large for discussion in this paper.

a Williston and Case, Jour. Geol., vol. xx, pp. I-I2, I9I2; Carnegie Inst. Wash. Pub. I8I, p. I, I9I3. 


\section{APPENDIX.}

\section{THE BRIER CREEK BONE-BED AND ITS FAUNA.}

BX E. C. CASE.

In the summer of I9I2 the author discovered this large bone-bed on the ranch of Mr. Estell, about I2 miles south of Dundee, a little east of the road between Dundee and Archer City, in Archer County, Tex. The next summer, with the help of Mr. W. I. Robinson, a graduate student in the University of Michigan, the bed was excavated as far as time permitted (plate 2I).

The bones occur in a light gray clay near the top of the Wichita formation. As has been previously shown by the author, the road running south from Dundee, in Archer County, Texas, marks approximately the first outcrop of the limestones which are regarded as the lower deposits of the Clear Fork formation. The bones were practically all isolated, but one or two partially complete skeletons being found, and almost all of the skull material consisted of separate bones. It is evident that the pool or swamp in which the bones were collected was more or less of a macerating tank in which the skeletons went to pieces and were disturbed by movements of the slimy mud and by the action of animals which trampled the decomposing bodies as they fed upon them or in their struggles to escape when mired. Toward one end of the bed the lowermost bones rested upon a layer of coarse gravel, indicating that a current may have swept the cadavers into the pool. As the bones are in many cases badly fractured and show signs of decay, but are never waterworn, it is probable that the bones themselves were not disturbed by currents after the bodies were macerated. Unfortunately the layer which contains the bulk of the bones was invaded, either before or after the solidification of the mud, by waters rich in iron, which destroyed the surface of the bones and at the same time cemented them into a hard mass from which they can not be recovered. Both above and below this layer there was an abundance of material in splendid condition, but if it had not been for the accident of the iron-bearing water invading the deposit the bones recovered would have been numbered by thousands instead of hundreds.

One of the first specimens discovered was the nearly complete skeleton of an Edaphosaurus cruciger Cope, consisting of the vertebral column to the base of the tail, most of the limb bones, the pelvic and pectoral girdles, and an imperfect skull. This gave hopes that other associated skeletons would be found, a hope that was, unfortunately, not realized. There have been identified:

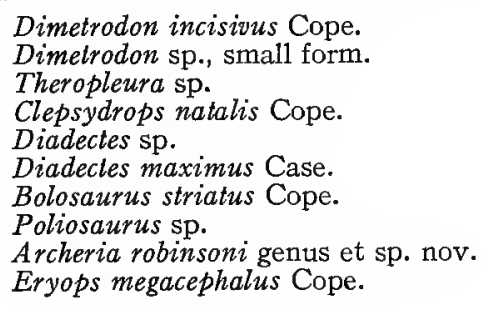

Cricolus heteroclitus Cope.

Diplocaulus sp.

Trimerorhachis (?) sp.

Dorsal plate of a member of the Dissorhophidæ.

Dermal scutes of an amphibian.

Numerous bones of amphibians and reptiles, many belonging to new forms, but some undoubtedly belonging to known forms described from incomplete material. 
The only forms listed as new are those indicated by bones which can not be, by any possibility, referred to forms already known. Certain new humeri, femora, scapulæ, and so forth, are provisionally referred to Cricotus, Theropleura, and others, as seems most probable.

The most abundant genera in the bed are Edaphosaurus and Cricotus, next comes a small form of Dimetrodon, with a good many bones of the larger Dimetrodon incisivus, and some bones which appear to belong to Dimetrodon gigas. The Cotylosauria are represented by a single imperfect vertebra of a Diadectes of medium size and a single humerus of a large Diadectes, probably $D$. maximus. This is very striking, as in the same region and at almost the same horizon the bones of Diadectes are very common. Several jaws and some limb bones and vertebræ of Bolosaurus occurred scattered through the bed.

The probably aquatic Cricotus occurs in abundance, with fairly numerous remains of Eryops, but it is singular that very few recognizable bones of the smaller amphibians were found. Zatrachys and Trimerorhachis are among the more common forms in the Wichita formation. The intercentra of these forms are generally very abundant, but in the Brier Creek bed only a single intercentrum and perhaps a humerus were found among the hundreds of specimens taken. The occurrence of Diplocaulus is one of the most interesting though not unexpected things. This genus occurs in the Illinois beds, certainly at a lower horizon, but previous to the excavation of this bed none had been found in the Wichita formation.

There is a total absence of any remains of fish. Sharks would undoubtedly have been attracted by the cadavers if there had been access to the pool from the open water, and the presence of dipnoan and crossopterygian fishes would certainly have been expected. The absence of these forms leads to the suggestion that the place of deposit was a stagnant pool or perhaps a spring or seep with an area of deep muck around it, in which the animals became mired. Such an assumption throws some doubt upon the aquatic character of Cricotus, which is so strongly indicated by the structure of its skeleton.

Aside from the light thrown upon the structure of old forms, the number of new things which have come to light in the bone-bed is of great interest. It is always to be expected that something new will be discovered in such large accumulations, but the very considerable number of new things is rather surprising. Unfortunately the new forms are represented by single bones or by separate bones which can not be associated with certainty; for this reason the author has not given new names to all, for there remains the possibility that some of the bones regarded as indicating new forms may belong to genera already described from fragmentary material.

\section{CRICOTUS.}

This genus is represented in the collection by abundant material of both large and small individuals. The author has previously ${ }^{a}$ suggested that but

\footnotetext{
¿ Carnegie Inst. Wash. Pub. I46, p. 78.
} 
two species of this genus can be determined from described material and is now inclined to be in doubt whether even this distinction can be made, though there can be little doubt that more than one species was present in the fauna. The species hypantricus was established by Cope upon the presence of small spout-like processes extending forward from the anterior edges of the neural canal. In the collection from Brier Creek vertebræ otherwise indistinguishable may be separated by the presence or absence of the process, but it is far from clear whether these are lost in some cases by accident, or may be present in one part of the column and absent in another.

Skull (fig. 32).--In common with most of the specimens recovered, the bones of the skull were macerated apart in most cases. The tops of two skulls were found together, and in one, No. $300 \mathrm{r},{ }^{a}$ the sutures can be clearly made out and establish the position and shape of the bones as described by Case and Broom.

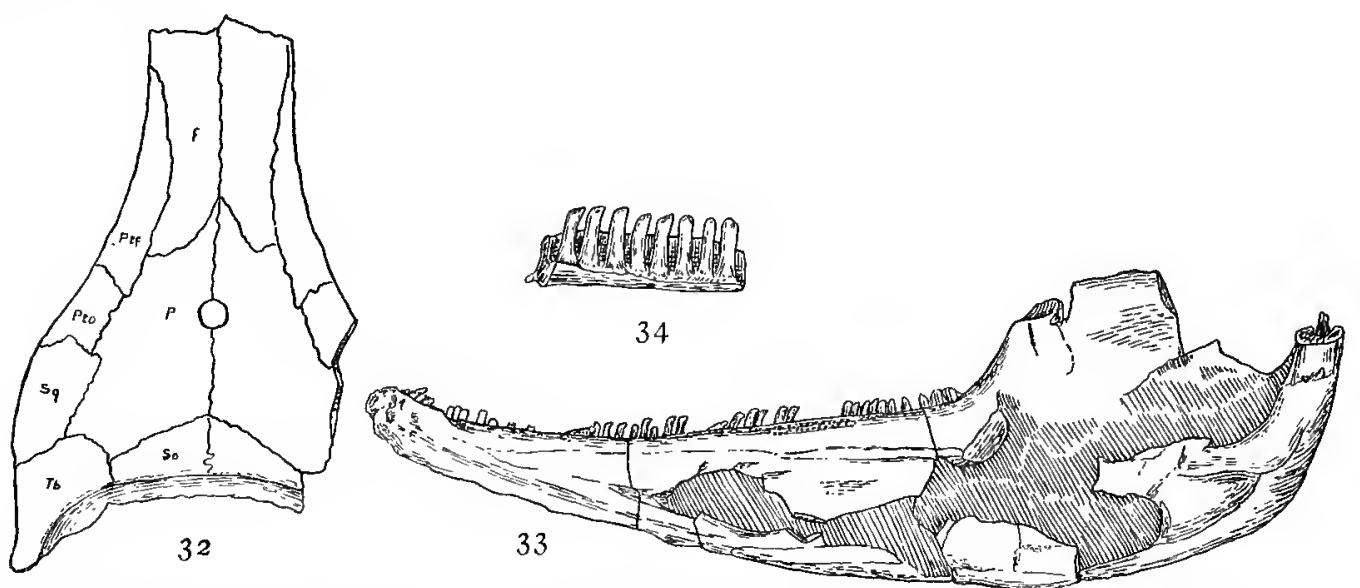

FIG. 32.-Cricotus heteroclitus Cope. $\times 2 / 3$. No. 3001. Upper surface of skull, showing sutures. $f$, frontal; $p$, parietal; $p t f$, postfrontal; pto, postorbital; $s q$, squamosal; $t b$, tabulare; so, supraoccipital.

FIG. 33.-Cricotus sp. $\times 1 / 3$. No. 3029. Outline of inner surface of large jaw.

Fig. 34--Cricotus sp. $\times \frac{2}{3}$. No. 3418. Fragment of a jaw, showing form of teeth.

One large jaw (fig. 33) nearly $300 \mathrm{~mm}$. long is nearly complete, lacking only the articular region. Unfortunately it was covered by a most refractory matrix, which makes it impossible to work out the sutures. The jaw, No. 3029, is very high posteriorly, with a strong coronoid region, but becomes very slender anteriorly. On the inner surface the posterior Meckaelian opening is very large; anterior to this there is a single, smaller opening. The walls of the jaw, surrounding the Meckaelian cavity, are relatively thin, permitting a large amount of fracturing. So far as can be made out, the splenial enters into the symphysis and forms the lower part of the anterior end of the jaw and the inner wall of the dental groove, at least in the anterior half of the jaw. In the anterior half of a small jaw, No. 3045 , the outline of the bone is clearly shown. Near the middle of the dental series of the large jaw there is a small patch of teeth on the inner wall of the

a In this article all numbers given, unless otherwise stated, refer to the collection of the University of Michigan. 
dental groove, possibly on the anterior end of the coronoid, but the outline of this bone can not be made out. The outer surface of the jaw is sharply reticulate. The sutures of the posterior end of the jaw can not be made out, but the general form is shown in figure 33. The most surprising thing about the jaw of Cricotus is the small size of the teeth and their peculiar form; 40 teeth of small size can be counted in the large jaw and there is no indication in this jaw, nor in any of the fragmentary ones recovered, of larger teeth at the anterior end. The teeth are long and slender, with broad bases fused to the edge of the dentary, but rapidly contracting to a cylindrical form. The apex is chisel-shaped, with the cutting-edge running fore and aft and the whole edge slightly moved to the rear, so that the posterior edge overhangs the posterior edge of the body of the tooth (fig. 34). The dental series occupies a deep groove formed by the dentary and the splenial and coronoid (?).

Vertebrce.-Of the numerous vertebræ found only two, intercentra and centra, were found in position; these are from the caudal series. The intercentra are fully as thick as the centra and very similar to them in appearance. The neural arches are anchylosed to the intercentra, at least to the elements which bear the chevron bones. In the figures published previously by Cope and Case the neural arch is shown directly above the chevron-bearing element and apparently supported by it; this is as the vertebræ appear in the specimens in the American Museum in New York; in the vertebræ in this collection the neural arches are in sutural connection with the elements bearing the chevrons and there can no longer remain any doubt of their position. The same condition is found in other stegocephalians.

It has been generally thought that the intercentra of the dorsal region were much thinner than the centra; thin disks regarded as intercentra are not uncommon in most collections from Texas, but few have been found in position. In the American Museum collection there is a sacral series with a thin disk directly posterior to the last sacral centrum (fig. 5 I E, Publication No. I46, Carnegie Institution of Washington), but without chevron or neural arch. Abundant thin disks with and without chevrons occur in all collections from Texas. The author is of the opinion that the thin disks without processes are pygal intercentra and that immediately following them in the anterior caudal region there are thin intercentra which bear chevrons. The tail was proportionately very long and strong and both the intercentra and the centra became elongated in the middle of the series, something after the manner of the mid-caudal vertebræ of the Eocene cetacean Basilosaurus. In this mid-caudal region the intercentra became as long as the centra and came to bear the neural arches as well as the chevrons.

Other thin disks with short diapophyses are believed to belong in the cervical series.

From the fact that the thin disks can be located with considerable certainty in the cervical and caudal series, and that they are in the minority in all collections, the author is inclined to the belief that the dorsal intercentra 
were as thick as the centra and resembled them very strongly. There are a large number of separate disks without neural arches, which are indistinguishable otherwise from the arch-bearing centra. They have a strong scar upon the upper surface, to all appearances identical with the scar which would appear upon the upper surface of the centra if the arch were removed. The presence of the scar is explained by the fact that the anterior edge of the neural arch extends far anterior to the edge of the centrum and in many of the vertebræ fits accurately into the scar mentioned. The original statement by Cope that the neural arches were not anchylosed to the centra is erroneous, as already shown by Case, and in the present collection there is no evidence that the arches were loosely attached, nor was a single separate neural arch collected.

A most striking feature in several of the vertebræ is the presence of a distinct canal, running lengthwise through the neural arch above the neural canal. This is clearly shown in at least five vertebræ, where it has been worked out, and is indicated in several others, where it is occluded by the compression of the specimen. In one vertebra, apparently an anterior dorsal, the canal-supraneural canal as it may be called - is higher than wide and separated from the neural canal by a considerable thickness of bone. The upper part of the arch is broken away, so that the exact dimensions of the opening can not be given (plate 22, fig. I). Two other vertebræ from apparently farther back in the series show similar canals. In one with the spine complete the canal is more nearly circular and the partition between it and the lower canal is very thin and has been in part destroyed by decay. In one of the larger anterior dorsals the canal is complete, but its upper twothirds appears to be divided vertically by a narrow partition.

The supraneural canal seems to be most perfect in the vertebræ with prominent transverse processes, regarded as anterior dorsals. Here it is narrow, but of considerable vertical extent, and is either complete or interrupted in a part of its aperture by a vertical partition. In the vertebræ with short transverse processes (anterior dorsals ?), the canal is small and circular, or the neural arch is imperforate but marked by very deep pits extending inwards in the position of the canal. In the sacrals deep pits are present, but the arch is imperforate. It is probable that this canal lodged a strong ligament which was in some parts of the column continuous and in others present in segments between the vertebræ.

Pelvis.-There are two perfect and two imperfect ilia which are provisionally assigned to the genus Cricotus. They differ from any known form of ilia from the Texas beds in possessing a long, thin process which starts from the middle of the posterior side of the crest and extends obliquely backward and upward. The sides of the process are flat and nearly parallel and the narrow terminal face evidently bore a cartilaginous extension. The lower portion of the bone is rather long proportionately and the cotylus is shallow. The articular faces for the pubis and ischium are rather thick (plate 22, figs. 2 and 3 ). 
The pubis (fig. 35) assigned to Cricotus has the inner side of the blade slightly concave. The anterior end of the inner or lower edge is thin anteriorly, but the posterior half is much thickened and there is a flat articular face for union with the bone of the opposite side. When the two bones were in position there was a large and rather deep notch at the anterior end of the pelvis. At the posterior end of the thickened portion there is a small, flat area running up to the foramen and looking obliquely backward and inward, probably for attachment with the ischium. The pubic foramen is near the posterior end and, as in the reptilian genus Varanosaurus, is incomplete behind. On the inner side of the upper edge, just above the anterior end of the foramen, or a little more forward, is a small, knob-like tuberosity.

The ischium.-There are several ischia in the collection of the general form common in the smaller Pelycosaurs. As this type is very abundant in the collection it may be that it belongs to Cricotus.

Humerus (plate 22, figs. 4 and 5 , and fig. 36 , $a$ and $b$ ).-There are four humeri of a new type, which are referred to the genus Cricotus. Three of

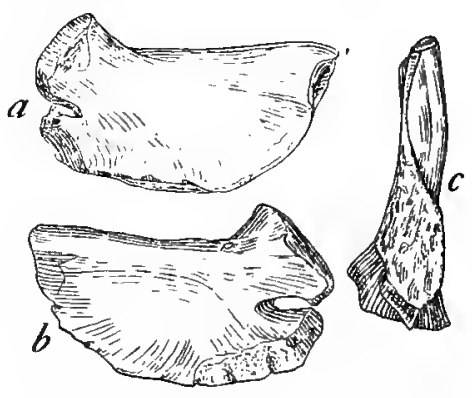

Fig. 35.-Cricotus sp. $\times 2 / 3$. No. 3247. Pubis of right side. $a$, outer face; $b$, inner face; $c$, inner edge. these (No. 34I9) are in excellent condition. They are peculiar in their extreme thinness and breadth. The articular surfaces of the ends are more nearly parallel than is common in this bone in the Permo-Carboniferous fauna. The proximal articular surface winds around the end of the bone and

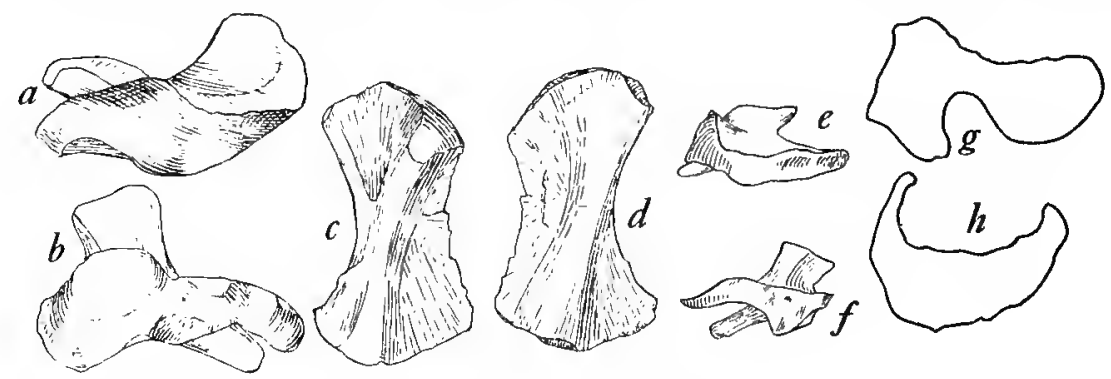

FIG. 36.-Cricotus sp. $\times 2 / 3$.

(a) Articular face of proximal end, (b) articular face of distal end of humerus, No.

3419. (Same bone as shown in plate 22, figs. 4 and 5.$)$
(c) Lower face, $(d)$ upper face, $(e)$ articular face of proximal end, $(f)$ articular face of distal end of humerus of an immature individual, No. 3420 .

(g) Distal end, $(h)$ proximal end of femur, No. 3366. (Outline of articular faces of bone shown in plate 22, fig. 6.)

descends upon the deltoid process. There is little or no widening of the end to form a head, and the deltoid process is but an extension of the outer edge of the bone, standing out at a low angle with the anterior face. The shaft is very thin and wide. From the center of the articular face on the deltoid process a sharp ridge passes downward and becomes the very thin outer edge of the bone; this knife-edge continues to the distal end of the bone, where it terminates in a small facet, evidently for cartilaginous attachment. The 
deltoid crest almost disappears distally, but there is traceable a low, rounded ridge extending obliquely across the anterior (upper) face of the bone to the outer side of the distal end. A similar low, broad ridge rises from the dorsal side of the inner edge of the proximal end and extends obliquely across the shaft to the distal end, where it becomes stronger and forms the posterior prominence of the widened face of the distal articular surface. The inner edge of the bone is thin, but not so sharp as the outer edge; it is short and sharply turned outward on the large entepicondylar process. There is no entepicondylar foramen, but there is a small ectepicondylar process. The distal articular surface is rather narrow; the radial condyle is very low and almost entirely on the anterior face of the bone.

This humerus resembles very closely the one figured by Williston as a new genus, but not named, from the Craddock bone-bed (Bull. Geol. Soc. Amer., vol. 2 I , pl. I5, figs. $1 a$ and $\mathrm{I} b$ ), but differs in its proportionately greater breadth, stronger deltoid process, proportionately higher entepicondyle, less rounded radial condyle, and the presence of a distinct ectepicondylar process. Length of figured specimen, $9 \mathrm{I} \mathrm{mm}$.

There are in the collection three much smaller humeri (No. 3420, fig. $36 c-f$ ) very similar in form to the one just described, but with all the characters less emphasized. These are probably from immature individuals of the Cricotus.

Femur.--The femur (Nos. 3366 and 3363, plate 22, figs. 6 and 7, and fig. $36, g, h)$ associated with bones of Cricotus is of a very simple type. The proximal end agrees very closely with the portion preserved in the New York specimen. The proximal articular face is semicircular and nearly flat, except where it descends upon the process of the inner side. This process is not distinct from the bone, being simply a more acute portion of the edge. The bicipital fossa is relatively shallow. The outer edge of the bone becomes very sharp just at the lower edge of the fossa and is continued as a sharp ridge directly down the outer side of the bone to the lower end, where it terminates upon the outer condyle. The section of the shaft is semicircular, with the outer edge much sharper than the inner. The distal face is confined to the end of the bone, looking almost directly distal. The face is divided by a deep groove on the posterior face, but the two halves are connected by a broad isthmus. An average specimen is $75 \mathrm{~mm}$. long.

Scapula (fig. 37, a, b, c).-Three imperfect scapulæ are of a form and size which suggest that they may belong with this genus. Only the scapula is preserved, no trace of coracoids being found (Nos. 342 I and 3422). The blade is short and curved, with a broad distal termination. The proximal end is disproportionately widened and there is a very large cotylus. The supraglenoid foramen is exceptionally large and pierces the supraglenoid fossa directly, as in the Cotylosaurs and Ophiacodon; it is far larger proportionally than in any known form from the Texas beds. The supracoracoid foramen is also very large; it opens anterior to the supraglenoid tuberosity and above the cotylus. 
Posteriorly both foramina open into the subscapular fossa, which has the crescentic outline characteristic of the Amphibia. There is a small and very sharp pit on the outer face of one specimen just beneath the cotylus, but this does not penetrate the bone and is probably adventitious. There are strong articular faces for the coracoid elements, and it is evident that these were suturally connected with the scapula during life. The anterior border is incomplete in all the specimens, but it was apparently rounded. The short and broad scapula is but another bit of evidence that Cricotus was aquatic-if this scapula belongs to that genus.

An ulna, radius, tibia, and fibula are here described as possibly belonging to the genus Cricotus, though the association is based upon little more than the appropriate size. They may very possibly belong to some other form.

The ulna (No. 3423, fig. $37, h$ ) has a large and well-developed cavity for the condyle of the humerus confined entirely to the anterior face of the proxi-

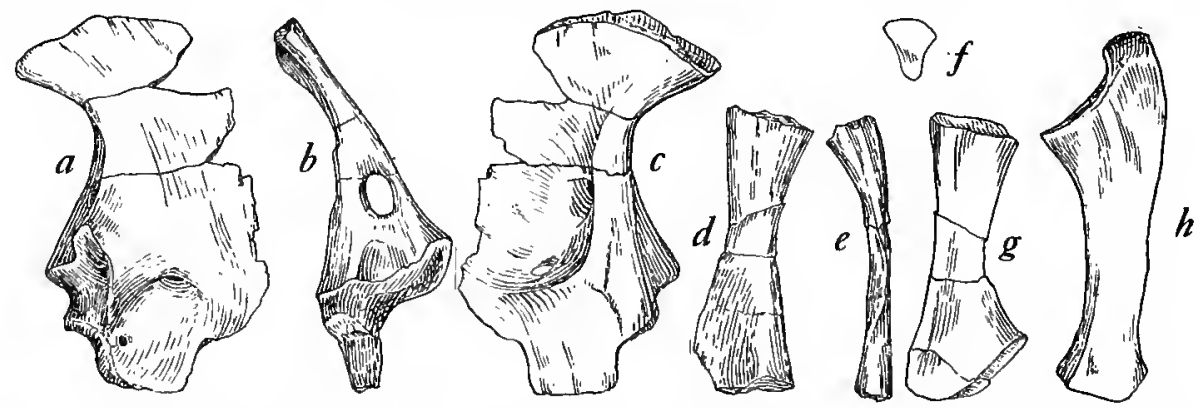

FIG. 37- - (a) Outer face, $(b)$ posterior edge, $(c)$ inner face of scapula of right side of Cricotus sp.; No. $3422 . \times 2 \%$

(d) Radius, No. 3424 ; (e) tibia, No. 3425 ; $(f)$ proximal face of tibia, $(g)$ fibula, No. 3426 ; (h) ulna, No. 3423. Lower limb bones provisionally referred to Cricotus (?) $\mathrm{sp.} \times 2 / 3$.

mal end. The inner face of the bone is nearly flat. The whole bone is slightly convex outward, with a suggestion of a sigmoid curve due to the expansion of the outer side of the proximal end and the rather sharp incurvature of the distal end. The distal face shows no division into facets and does not lie in the same plane as the proximal end; a slight twist of the shaft turns the outer edge of the face slightly. The section of the shaft is oval-triangular, with the greatest thickness at the anterior edge. Length $55.5 \mathrm{~mm}$.

The radius (fig. $37, d$ ) is very simple. The shaft is somewhat flattened and the articular ends are oval. On one side of the lower end the shaft is flattened and the edge very thin and somewhat expanded. Length $44 \mathrm{~mm}$.

The tibia (fig. 37, $e$ and $f$ ) is rather slender, with the proximal end slightly enlarged and the face nearly triangular. Length $44 \mathrm{~mm}$.

The fibula (fig. $37, g$ ) has an oval proximal face, the shaft is flattened, and the distal end is much widened and divided obscurely into two facets. The inner facet looks obliquely inward and downward and the outer facet looks directly downward. Length $52 \mathrm{~mm}$.

Any or all of these bones may belong with the reptilian humerus No. 3354 (plate 24, fig. I). 
ERYOPS.

Although so much has been written about this genus the collection permits a few new points to be added.

The interclavicle and clavicle have been known from almost the first discovery of the genus, but have been found preserved in such refractory matrix that the exact character of the sculpture has not been clearly seen. The specimens from the Brier Creek bone-bed are so well preserved and naturally cleaned that this character is beautifully shown. The interclavicle (plate 23 , fig. I) is slightly imperfect, having lost some of the slender processes on the anterior and posterior borders, but it is apparent that very little can be missing. The posterior end of the clavicle (plate 23, fig. 2) is greatly foreshortened in the photograph; the small patch of very coarse sculpture marks the position of a sharp bend in the bone.

The cleithrum (plate 23 , figs. 3 and 4 ) has been known to exist, but no perfect specimen has previously been recovered. It is gently sigmoid in outline, with the anterior two-thirds drawn out into a slender process nearly circular in section. The distal end of this process is marked by strong, linear rugosities. The posterior third is expanded into a scimitar-shaped blade, very thin on the convex edge but thick at the point of union with the slender process. The thin edges show some radial striations. The inner side of this portion is excavated by a deep linear cavity, into which fitted the upper edge of the scapula.

Humerus.-A small humerus (No. 33 I6, fig. $38, a, b, c$ ) is very probably that of an immature Eryops. The articular faces are deeply concave, as if there

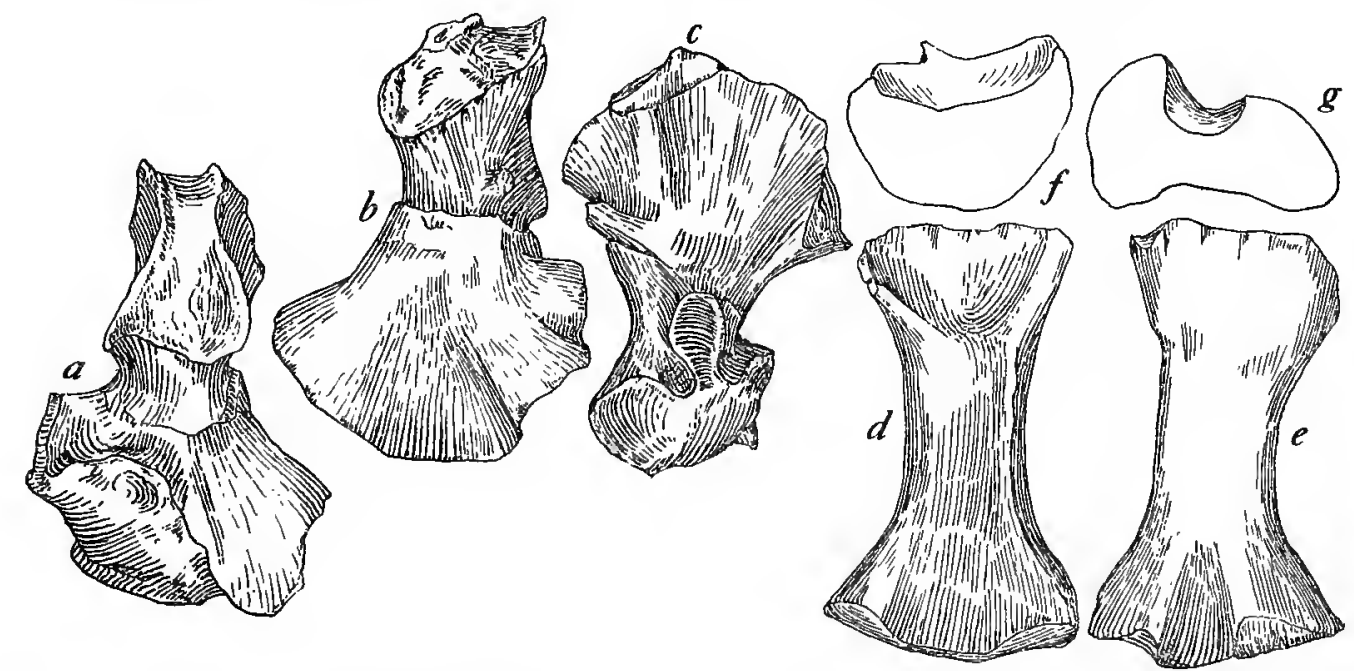

FIG. 38.- (a) Anterior face, $(b)$ posterior face, $(c)$ outer edge of right humerus of an immature individual, Eryops megacephalus Cope, No. $3316 . \times 2 / 3$.

$(d)$ Lower face, $(e)$ upper face, $(f)$ proximal face, $(g)$ distal face of femur of an immature individual, probably Eryops(?), No. 3432. $\times 2 / 3$. (The original is broken and the figures $(d)$ and $(e)$ are somewhat restored.)

had been a large mass of cartilage attached. In general the form is that of an Eryops humerus, but the bone is proportionately shorter and heavier. The ectepicondylar process is not separate from the distal articular face, and the process on the dorsal surface of the inner edge of the proximal end is quite 
small. The bone resembles in many respects the one figured by Williston (Bull. Geol. Soc. Amer., vol. 2 I, pl. I 5, figs. 4a, $b, c$ ), but differs in the presence of the process on the dorsal surface of the inner edge of the proximal end. The articular faces, also, do not correspond with the figures given by Williston. Nevertheless I am inclined to think that the bones are the same and that the process mentioned has been lost in Williston's specimen.

Femur.-No. 3432 (fig. $38, d-g$ ) is a small and rather heavy femur which is evidently that of an amphibian but is not referable to any known form, unless it belong to an immature Eryops. There is a deep bicipital fossa and a very strong prominence on the inner edge near the middle of the shaft. The proximal articular face is crescentic in outline, flat, and confined to the end entirely. The distal face is wide transversely and narrow antero-posteriorly; the tibial and fibular faces are undivided. If this is the femur of an immature Eryops there must have been very considerable changes in the proportions of the bone during development. The ridge on the anterior face would have to become more prominent and the bone more elongate and slender. The specimen has been broken and crushed so that it is a little difficult to restore it exactly, but an attempt has been made in the figure.

UNASSIGNED FORMS, AMPHIBIA.

There are three femora which are regarded as amphibian. It is noticeable in the collection that the femora can be divided into two groups, one in which the adductor ridge on the posterior face crosses the shaft obliquely and one in which the ridge is confined to the inner edge and passes directly downward to the distal end of the bone. Those in which the ridge is oblique are regarded as reptilian and those with the ridge confined to one side as amphibian. This seems to be the most common arrangement in the two groups, though in Ophiacodon the ridge is confined to one side of the bone.

The first femur (No. 3298, fig. 39, a, $b, c)$ is regarded as probably amphibian because of the position of the adductor ridge, although its general form is that of a reptile. The shaft is very long and slender and the ridge is very thin and
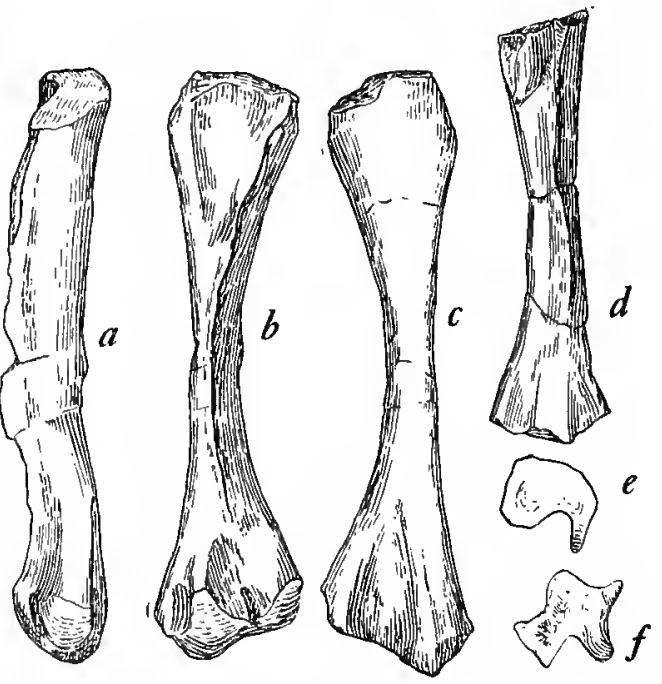

1G. 39.-(a) Inner edge, (b) lower face, (c) upper face of femur of right side of unnamed amphibian (?), No. 3298 . $\times 2 / 3$.

(d) Lower face, $(e)$ proximal face, $(f)$ distal face of femur of right side of unnamed amphibian, No. 343 I. $\times 2 / 3$.

prominent. In this respect it resembles the femur from the Craddock bonebed figure by Williston (Amer. Perm. Vert,, pl. xxxII, fig. 4), but differs decidedly in the well-formed and very reptilian looking proximal and distal 
articular surfaces. The proximal end has a deep bicipital fossa, but lacks any distinct process on the inner side, its place being taken by the upper end of the ridge, which is here slightly thickened. The distal face is very similar to that of a Pelycosaurian reptile, being sharply divided into two faces by a deep groove on the anterior face. This bone may very possibly turn out to belong to a reptile when the skeleton is known.

The second femur (No. 343 I, fig. 39, $d, e, f$ ) is similar to the one from the Craddock bone-bed figured by Williston (Amer. Perm. Vert., pl. XxxIII, fig. 4) and by him referred to Broiliellus (Aspidosaurus) peltatus. It is devoid of wellmarked articular condyles but has a prominent adductor ridge. It is probably to be associated with the single dorsal plate discovered (No. 3404), described below. Length $53.5 \mathrm{~mm}$.

The third femur (No. 3295) (plate 23, figs. 5 and 6, and fig. $40, a$ and $b$ ) is also typically amphibian and might be regarded at first as that of a young Eryops, as the articular ends are deeply excavated, indicating the presence of considerable cartilage, but closer study reveals essential differences. The adductor ridge is relatively much higher and thinner than in the adult Eryops.

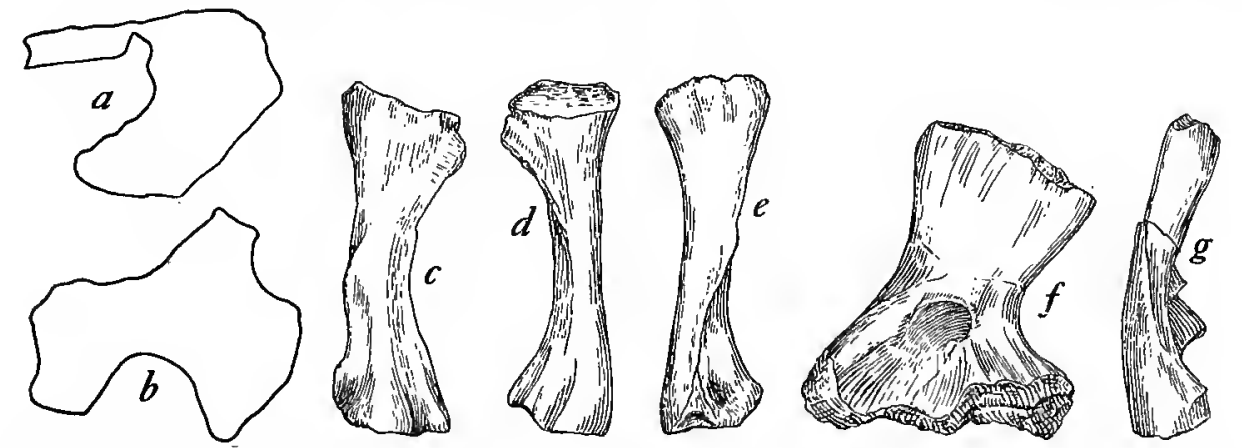

Fig. 40.- (a) Proximal face, (b) distal face of unnamed amphibian, No. 3295. $\times 2 / 3$. (Articular faces of bone shown in plate 23 , figs. 5 and 6 .)

$(c),(d),(e)$ Three views of tibia or radius of an unnamed amphibian, No. $3299 . \times 2 \%$.

$(f)$ Outer face, $(g)$ anterior edge of ilium of left side of unnamed amphibian, No. $3430 . \times 2 / 3$.

In the adult of that genus there is a very deep bicipital fossa and its edges meet below in a strong, almost rugose, prominence at about the middle of the shaft; below this the ridge is very thick, with a flat terminal face, and is continued to the distal end of the bone. In the new form the tibial side of the bicipital fossa is a strong ridge which develops at the upper third of the bone into a strong, circular, and rugose tuberosity with a depressed face; below the tuberosity the ridge is very thin, almost a knife-edge, and it terminates a considerable distance above the distal condyles. The articular faces are proportionately larger than in the adult Eryops. Length $98 \mathrm{~mm}$.

A bone, No. 3299, is probably amphibian and is either a tibia or a radius. The form is best understood from figure $40, c, d, e$. Length, $56 \mathrm{~mm}$.

A small ilium, No. $343^{\circ}$ (fig. 40, $f$ and $g$ ), resembles in many ways that of Eryops and may be that of an immature individual of the genus. There are, however, some important differences. The crest is vertical like that of Eryops, 
but the posterior edge does not overhang the ischial border, forming a deep notch. The anterior edge of the lower end of the ilium is thickened, but not after the manner of Eryops. In that genus there is a sharp ridge on the inner edge of the bone and the outer edge is concave, but in this specimen the whole bone is convex from without inward. The cotylus is relatively higher than in Eryops.

A neural spine (plate 22, figs. 8 and 9), with the arch and transverse process, and the apex of a second spine, No. 3294, indicate the presence of an as yet undescribed amphibian, probably in the line of Zatrachys or Aspidosaurus.

The neural arch is typically that of a temnospondylus form with welldeveloped zygapophyses and transverse processes. The spine is relatively very high, fully as high as that of an Eryops vertebra of three or four times its size. It belongs to a distinctively high-spined amphibian and is the first indication of such a form in the Texas beds. The only other form with high spines which has been regarded as showing amphibian characters is Platyhistrix, from the New Mexican beds, and this probably is a reptile. The exact position of the form can not be stated; it probably belongs to the as yet poorly understood line in which occur Zatrachys, Aspidosaurus, and Dissorophus. It is noteworthy that but a single intercentrum of a temnospondylus amphibian of small size was found in the large amount of material taken from the bed; this may be due to accidents in accumulations of the material, but if so it is very peculiar. I would rather attribute it to the peculiar association of animals in the bed. However, many small forms of amphibians were found which are in all probability temnospondylus, and the peculiarity must await future explanation.

The upper end of the spine is flattened from side to side and is somewhat spatulate in form. The deep reticulate rugosities cover the upper end and extend down upon the sides to a point a little below the middle of the spine, becoming narrower below and terminating in a blunt point. The anterior and posterior edges of the spine and the spaces below the rugosities are smooth. The second specimen, the apex of a spine, is expanded after the manner of Zatrachys apicalis and is rugose on the top only.

Length from base of thetransverse process to the top of the spine $86.5 \mathrm{~mm}$.

No. 3404 (fig. 4I, $a$ and $b$ ) is a single dorsal plate from the apex of a spine of a small amphibian. This resembles the plates from the dorsal region of Cacops aspidephorous Williston, in general form, but was free from the spine, as in the Dissorophidæ. Aspidosaurus has been reported from the Clear Fork beds as low as just west of the Dundee-Archer City road, i.e., the lowest part, but this is the first specimen of the small armored amphibians from the Wichita formation. The upper surface is deeply rugose, with relatively large pits; one edge, the anterior (?), is free from pits for a short distance, but is marked with fine lines, evidently marking the position of an overlap by the preceding plate. The lower surface shows very slight projections in the middle portion, as if the plate were loosely attached by cartilage to the apex of the spine below. 
UNASSIGNED FORMS, REPTILIA.

A femur, No. 3363 (plate 24, fig. 5, fig. 42, $a$ and $b$ ), is rather short and heavy, but not radically different from some known forms. The proximal articular face is rather narrow, slightly thicker at the inner side, and confined entirely to the end, except where it descends a little upon the inner edge. The process is sharply set off from the inner edge and terminates well below the end of the bone in a flat, oval face looking nearly straight upward. From the base of the process a sharp adductor ridge runs obliquely across the lower face of the bone to the opposite of the distal end. Aside from this ridge the shaft is nearly circular in section. The lower end is expanded and the articular face has a continuous articular area; the inner part is the broader and is partly cut off from the outer by a deep groove on the anterior face of the bone. This part of the articular face looks obliquely inward and backward. The outer part is narrow antero-posteriorly and looks obliquely outward and backward. This bone resembles in many respects the bone figured by Case (Publication 55, Carnegie Institution of Washington, plate 5, fig. 7) as the femur of Clepsydrops and by Williston (American Permian Vertebrates, plate 24, figs. 5, 6, 7)
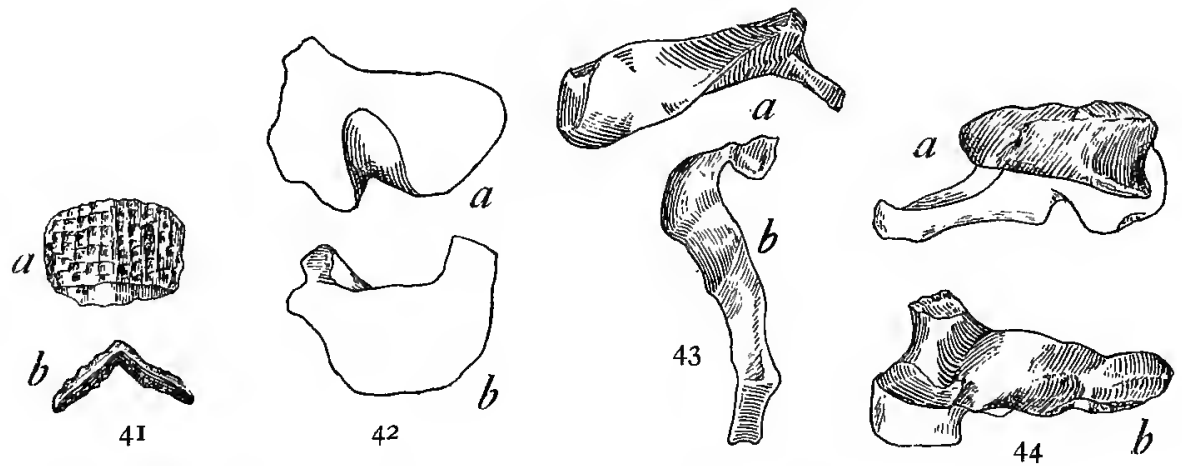

FIG. 4I.-Unnamed amphibian. $\times 2 / 3$. No. 3404. Dorsal plate. $a$, upper face; $b$, anterior edge.

FIG. 42.-Unnamed reptile. $\times 2 / 3$. No. 3363. Articular faces of femur shown in plate 24 , fig. 5. $a$, distal face; $b$, proximal face.

FIG. 43.-Unnamed reptile. $\times 2 / 3$. No. 3354. Articular faces of humerus shown in figures I and 4 , plate 24 . $a$, proximal face; $b$, distal face. The faces are arranged in their natural position.

FIG. 44.-Archeria robinsoni. $\times 2 / 3$. No. 3246. Articular faces of the humerus shown in plate 23 , figs. 7 and 8 . $a$, proximal face; $b$, distal face.

as the femur of Captorhinus illinoisensis. There is much doubt that it is the femur of a true captorhinid, as that group does not occur in the Wichita formation nor in the Illinois beds. The vertebræ of the captorhinids are so characteristic and bones from the vertebral column are so much more abundant than from other parts of the skeleton that they could scarcely fail to be recognized if present. The femur is tentatively associated with the humerus described below (No. 3354).

There are two types of humeri which are different from forms previously described. The first type, No. 3354 (plate 24 , figs. I to 4 , fig. $43, a$ and $b$ ), is represented by six good specimens of different size. The group forms a series, the extremities of which might be regarded as belonging to different species, 
but taken as a whole seem certainly to belong together. The largest specimen, evidently from an adult form, resembles most remarkably the humerus of Ophiacodon mirus Marsh (fig. 31 A, Publication I8I, Carnegie Institution of Washington; fig. 5, plate 35, Amer. Perm. Vertebrates). The differences noted between this bone and the humerus of Ophiacodon are: In Ophiacodon the distal and proximal ends are "relatively little divergent"; in this form they are at right angles. The ectepicondylar process in Ophiacodon extends dorsally at nearly a right angle; in this form it extends dorsally and outwards at an angle of $45^{\circ}$. The radial condyle of Ophiacodon is nearly circular and looks largely forward; in this form it is smaller and looks more distally than forward.

TABLE 4.-Proportional Measurements of Specimens.

\begin{tabular}{|c|c|c|c|}
\hline & $\begin{array}{c}\text { Yale } \\
\text { specimen } \\
\text { of } \\
\text { Ophiacodon }\end{array}$ & $\begin{array}{c}\text { Chicago } \\
\text { specimen } \\
\text { of } \\
\text { Ophiacodon }\end{array}$ & $\begin{array}{l}\text { University } \\
\text { of } \\
\text { Michigan } \\
\text { specimen }\end{array}$ \\
\hline Lengt & $\begin{array}{l}m m . \\
72.8\end{array}$ & $\begin{array}{c}m m . \\
\text { IOI }\end{array}$ & $\begin{array}{c}m m . \\
85\end{array}$ \\
\hline Brcadth distal end & 49 & 34.6 & $47 \cdot 4$ \\
\hline
\end{tabular}

In the smaller specimens the ectepicondyle is less prominent and the articular faces are less well formed and distinct, as would be expected. The proximal articular face is continued out upon the deltoid process, but in the larger bones this connection is broken by the connecting ridge becoming thinner until the face upon it disappears. The entepicondylar foramen is nearer the lower end.

The second type of humerus is so radically different from any form as yet discovered in the Texas beds that it is certainly new and may be called Archeria robinsoni. The whole bone (plate 23, figs. 7 and 8, fig. 44, $a$ and $b$ ), represented by one complete and two incomplete specimens (No.3246), is very thin and broad, resembling in this character the form assigned to Cricotus, but differs from it very largely in other particulars. The articular surface of the proximal end is confined to the inner half of the extremity and has the oblique position common to the Pelycosaurs. The deltoid process is well down on the anterior side and has a large facet deeply sunk in the end of the process. The outer edge of the bone is thin, terminating in a knife-edge; it originates from the back of the deltoid process and curves sharply backward at first; turning, it runs straight down to the distal extremity, becoming slightly thicker at the distal end. The inner edge runs slightly inward for its proximal one-third or more and then bends sharply outward on the entepicondylar process at nearly a right angle to its former course. This edge is thin, but not sharp, as is the outer edge. The entepicondylar process is large, being approached in this regard, so far as I know, only by Casea and the Diadectid reptiles. The entepicondylar foramen perforates the bone just at the point of junction of the process with the shaft. The inner edge of the process has a very narrow face, with evidence of the attachment of a cartilaginous extension. 
On the posterior face of the bone a ridge starts just above the opening of the foramen and runs obliquely across the bone; becoming sharper and higher toward its distal end, it terminates free from the articular face. The distal articular face is confined entirely to the end of the bone. The face for the ulna is slightly oblique, winding around the end of the bone; the radial condyle is hardly distinguishable.

Length of the bone, $87 \mathrm{~mm}$. Width at upper edge of the entepicondylar process, $49.5 \mathrm{~mm}$. Height of the entepicondylar process, $44.5 \mathrm{~mm}$.

Pelvis. - There are a number of ilia (No. 3428, fig. 45, $a$ and $b$ ) more closely resembling that of Varanosaurus than any other known form from the Texas beds, but as Varanosaurus does not occur in the Wichita, these bones are provisionally associated with Poliosaurus as the most likely form. A perfect specimen of average size has an elongated narrow crest projecting almost directly to the rear. The outer face of the crest is smooth, but on the inner face there is a strong, sharp ridge standing out at right angles to the rest of the bone. The anterior end of this ridge is the highest and it gradually diminishes until it disappears upon the distal portion of the face. The ridge is almost identical with that found in the same position in Varanosaurus and
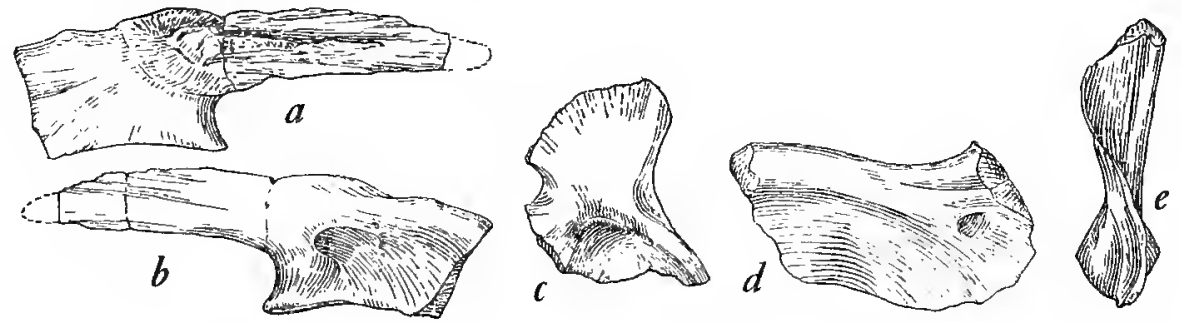

FIG. $\underset{\times 2 / 3}{45}$.

(c) ilium of right side of unnamed reptile, No. $3429 . \times 2 / 3$.

(d) inner face, $(e)$ inner edge of pubis of right side of unnamed reptile, No. 3245 . $\times 2 / 3$.

Pacilospondylus and perhaps is to be regarded as indicating some relationship between the forms mentioned from the upper and lower formations. The similarity to Varanosaurus is also to be seen in the somewhat elongated cotylus, with the face for the ischium longer than that for the pubis, the two faces standing almost at right angles to each other. Length of an average specimen, $58.5 \mathrm{~mm}$.

It is possible that the pubes referred to Cricotus may belong with this ilium and to Poliosaurus, for they strongly resemble the pubes of Varanosaurus.

A small ilium, No. 3429 (fig. 45, c), is totally different from the preceding; it may be that of an amphibian, but is more probably reptilian. The crest is somewhat imperfect, being slightly broken at the posterior end. The cotylus is relatively deep. The articular surfaces for the pubis and ischium are deeply hollowed out, showing the presence of a considerable quantity of cartilage and the probable immaturity of the animal. The form is best appreciated from the figure. 
Pubis.--The pubis No. 3245 (fig. 45, $d$ and $e$ ), considered as reptilian, resembles very closely that of Varanosaurus, having the same peculiar bending of the plate-like anterior portion, giving the floor of the opening a convex surface, upward, both fore and aft, and from side to side. It differs from the same bone in Varanosaurus in the position of the foramen, which is well within the bone instead of being so near the posterior end that its posterior border is incomplete and is closed by the adjacent portion of the ischium. This pubis probably belongs to Clepsydrops or Poliosaurus.

LOWER LIMB BONES.

There are certain bones of the lower limbs which are so heavy and short that they can not be associated with any of the bones described above. It is possible that they may belong with some of the amphibians or may even be bones of immature individuals of Eryops, but they differ so widely from the mature bones of the last genus that it seems more probable that they belong to some form of diadectid reptile otherwise unindicated.

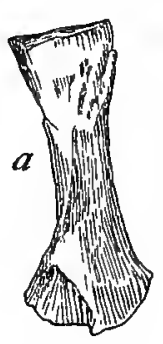

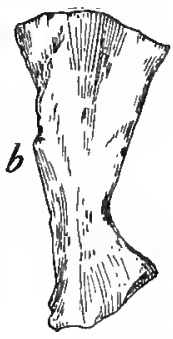
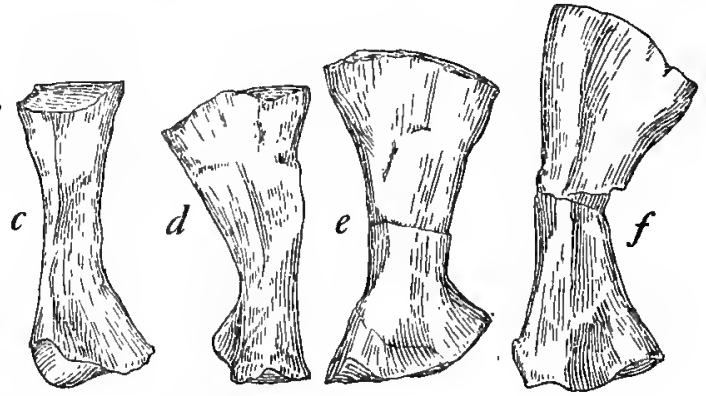

Fig. 46.-Unnamed reptile. $\times 2 / 3$.

(a) (b) (c) (d) four views of tibia, No. 3355; (e) tibia, No. 3433; $(f)$ ulna, No. 3434 .

Two tibiæ, No. 3355 (fig. 46, $a, b, c, d$ ), are rather short and heavy, with a poorly developed groove on the anterior face of the upper end. The proximal articular face is semicircular, with its long axis nearly at a right angle to the long axis of the distal face. The shaft is angular, due to the development of ridges, one extending from the inner edge of the proximal end to the corresponding point on the distal end, another from the outer part of the anterior edge of the proximal end to the outer part of the posterior edge of the distal end. Length, $48 \mathrm{~mm}$.

Three tibiæ, No. 3433 (fig. 46, e), similar to the preceding but lacking the strong twisting of the shaft which brings the two faces into such strong angulation, also lacking the prominent ridges.

Two ulnæ, No. 3434 (fig. 46, $f$ ), which may belong to an immature Eryops. These, of all the fore-limb bones, approach nearest to the amphibian type, but can scarcely be assigned to the genus Eryops with certainty. The proximal face is nearly circular and quite flat, but is strongly inclined forward. The shaft narrows rapidly below the head and then expands slowly to the distal end. The distal articular face is a narrow oval with a slight undulation of the inner edge. Length, 61.5 mm. 
Vertebre.-It is most peculiar that in all the material there are practically no reptilian vertebræ of the Cotylosauria; a single imperfect vertebra of Diadectes and a few Bolosaurus vertebra have been determined. The remainder of the many hundred vertebræ found are Pelycosaurian. Aside from numerous axis vertebræ which may with certainty be referred to different species of Dimetrodon, large and small, there are two which belong to the short-spined Pelycosaurs. The first, No. 344I (fig. $47, a$ and $b$ ), is represented by a complete neural arch and by an imperfect arch with a half of the centrum. The arch is relatively low and heavy, broader behind than in front, and with a pit at the posterior end of the upper edge. The anterior end does not project over the anterior edge of the vertebra, as in Dimetrodon. The posterior edge is thickened and rounded above, but below terminates in a deep pit between the edges, which extend out upon the posterior zygapophyses. The anterior zygapophyses are small and almost rudimentary; the posterior are fully formed. The transverse processes descend from the anterior end of the arch. This is probably the arch of the axis of Theropleura.

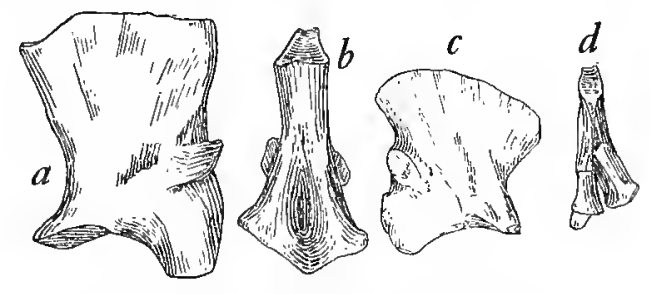

Fig. 47.-Neural arch of axis.

a, from side, (b) posterior face, of Theropleura (?), No. $344 \mathrm{I} . \times 2 / 3$.

$c$, from side, $(d)$ posterior face, of unnamed reptile, No. $3442 . \times 2 / 3$.

The second arch, No. 3442 (fig. $47, c$ ), is similar to the one just described, but is more slender. The spine is more expanded antero-posteriorly, so that the edges overhang the lower edges of the arch. The posterior edge is thin, and, instead of ending in the pit between the posterior zygopophyses, is continued as a sharp ridge on the bottom of the pit for some distance. At present it is impossible to assign this axis to any known form, though it may well belong to some one already described.

Scapula.-There are several scapulæ, mostly without the coracoid elements. Certain of them are probably amphibian, but as this point is uncertain the bones are described together for easier comparison.

The first scapula, No. 3059, is undoubtedly that of a Pelycosaur and in all probability belongs to some species of Dimetrodon. The nearest bone, in general form, to this is the scapula in the American Museum in New York described by the author as Dimetrodon longiramus (Publication 55, Carnegie Institution of Washington, p. 56, fig. I6). It differs from the typical Dimetrodon scapula in the relative shortness of the blade and the greater breadth. It is almost identical with the $D$. longiramus, except that the cotylus is somewhat larger (plate 22, fig. II). 
The remaining scapulæ may be divided into two groups: those with a foramen in the supraglenoid fossa and those without such a foramen. The first condition mentioned has previously been observed only in the Cotylosauria and in Ophiacodon.

Figure $48, c, d$ and $e$, shows two imperfect scapulæ of the first kind (No. 3435). The blade is slender and resembles in proportions that of Dimetrodon. The coracoid portion is wide and rounded in outline; the sutures can not be certainly made out, but there are breaks in the normal position of the sutures and probably follow them. The cotylus is exceptionally deep, with the scapular face looking almost directly downward. The front limb must have been held almost at a right angle to the body.

A second scapula, No. 3439 (plate 24, fig. 8), of similar form but much larger, is represented by a nearly perfect scapula and part of the coracoid. The supraglenoid foramen occupies the same position and the cotylus is proportionately as deep. Both this and the smaller specimen show a strong ridge on the outer face

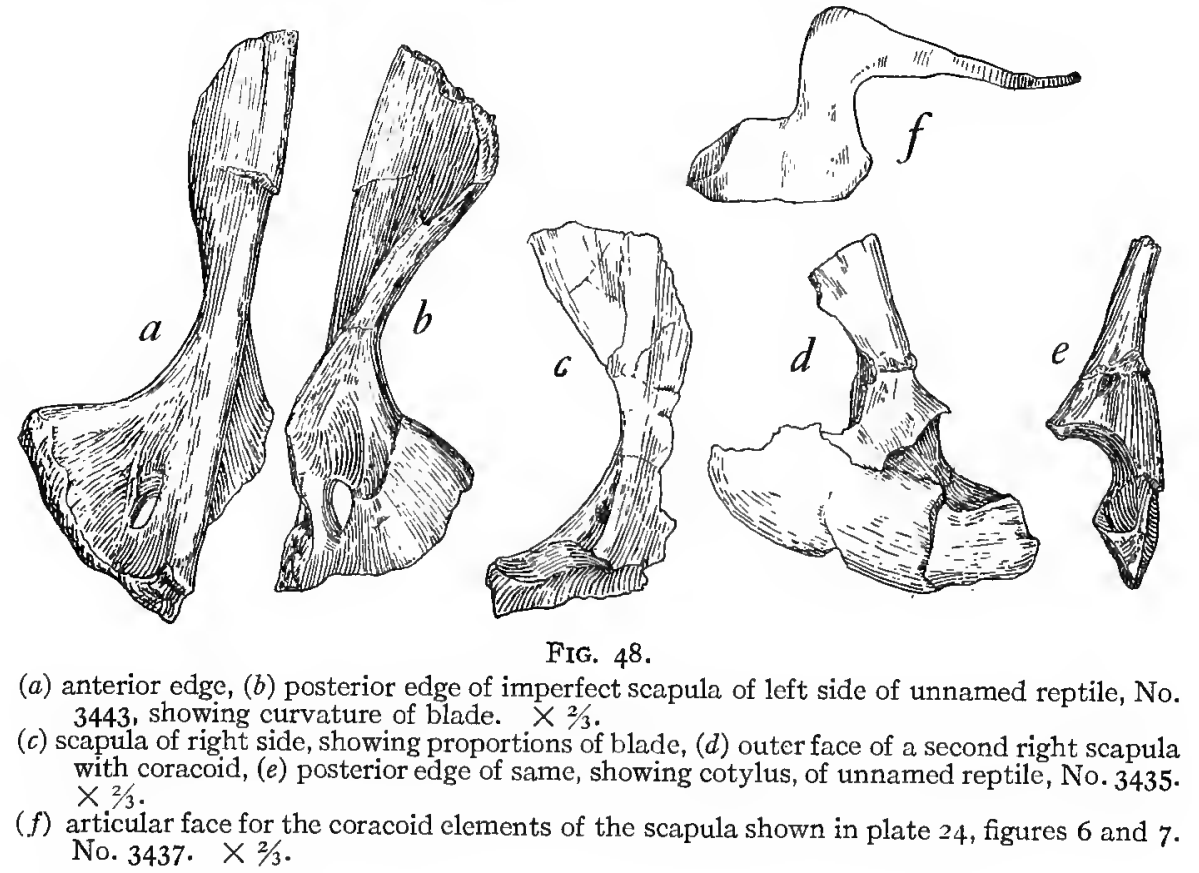

of the blade, probably marking the lower limit of the cleithrum. The supracoracoid foramen is very small and lies just beneath the scapular process of the cotylus. Another (imperfect) scapula (No. 3443), figure $48, a$ and $b$, is probably related to this one, but shows a most remarkable peculiarity in the curvature of the blade, which gives it a strong resemblance to the pubis of Varanosaurus. It can not be regarded as a pubis, however, and while a single bone can not be considered as sufficient material upon which to establish a new order, it is altogether probable that it indicates the existence of a new group of animals.

It may be that these scapulæe with the epicondylar foramina will turn out to be amphibian. 
The second type of scapula is represented by two or three different forms. The first of these (No. 3437) is shown in plate 24 , figures 6 and 7 and figure $48, f$. The posterior edge of the blade is slightly injured by decay, but it is apparent the line was slightly concave. The anterior edge is nearly straight and is directly continuous with the strong anterior edge of the supraglenoid fossa. The supraglenoid fossa is much larger than is common, due to the very posterior position of the posterior edge, which carries the articular portion of the cotylus. The fossa is deep and at its base there is a deep pit in the position of the foramen in the scapulæ described above, but there is no perforation of the bone. The articular surface for the coracoid elements presents a most peculiar outline, due to the strong development of the anterior and posterior edges of the epicondylar fossa.

A fragmentary coracoid (No. 3444, fig. 49, $a$ and $b$ ) in the collection evidently belongs with this type of scapula. So far as can be told, the outline

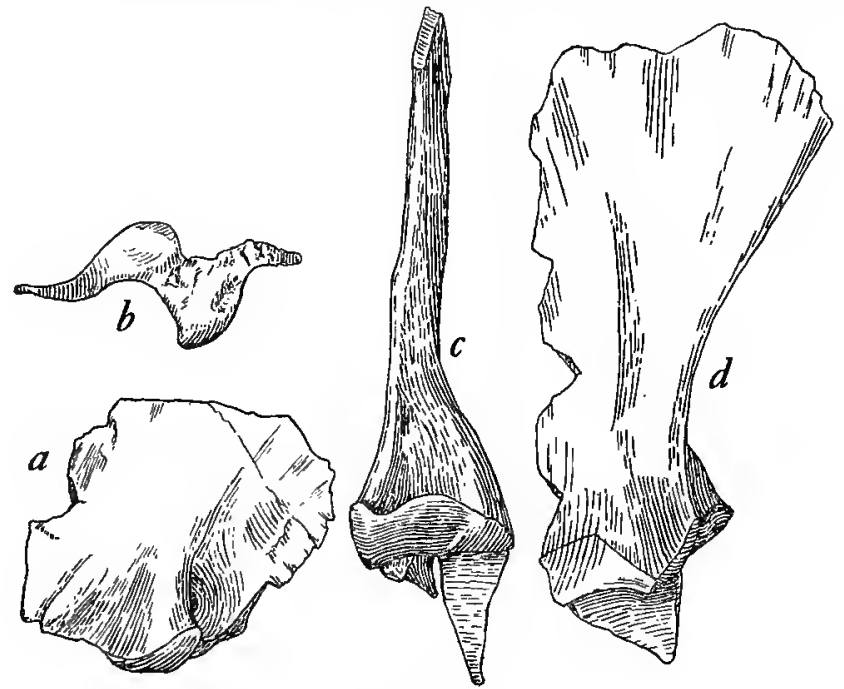

FIG. 49. -Unnamed reptiles. $\times 2 / 3$.

(a) showing strong ridges and position of the foramen, (b) articular face for scapula of coracoid. No. 3444 .

(c) posterior edge, (d) outer face of scapula of left side. No. 3436 .

was rounded, but the proximal portion, where it articulated with the scapula, is marked by two strong ridges, between which lies the foramen. The outline of the articular surface corresponds with the face of the scapula just described. The peculiarities of these bones indicate the existence of an animal that can not be placed in any group as yet described; it is very possible that they belong to some form of amphibian.

Another form of scapula, resembling the preceding but smaller, is represented by two specimens, one (No. 3436, fig. 49, $c$ and $d$ ) with a fragment of the coracoid attached and one less perfect. The anterior edge of the blade is more concave and the whole blade is more slender. The anterior edge of the supraglenoid fossa is not so prominent and the fossa is less deep, without the pit. It is possible that these are from immature individuals. 
The last type of scapula (No. 3438) is represented by several imperfect specimens. It is more like that of Dimetrodon, especially in the region of the epicondylar fossa, and differs from that form mainly in the short, rounded coracoid elements. It is probable that this scapula belongs to Theropleura or some closely related form.

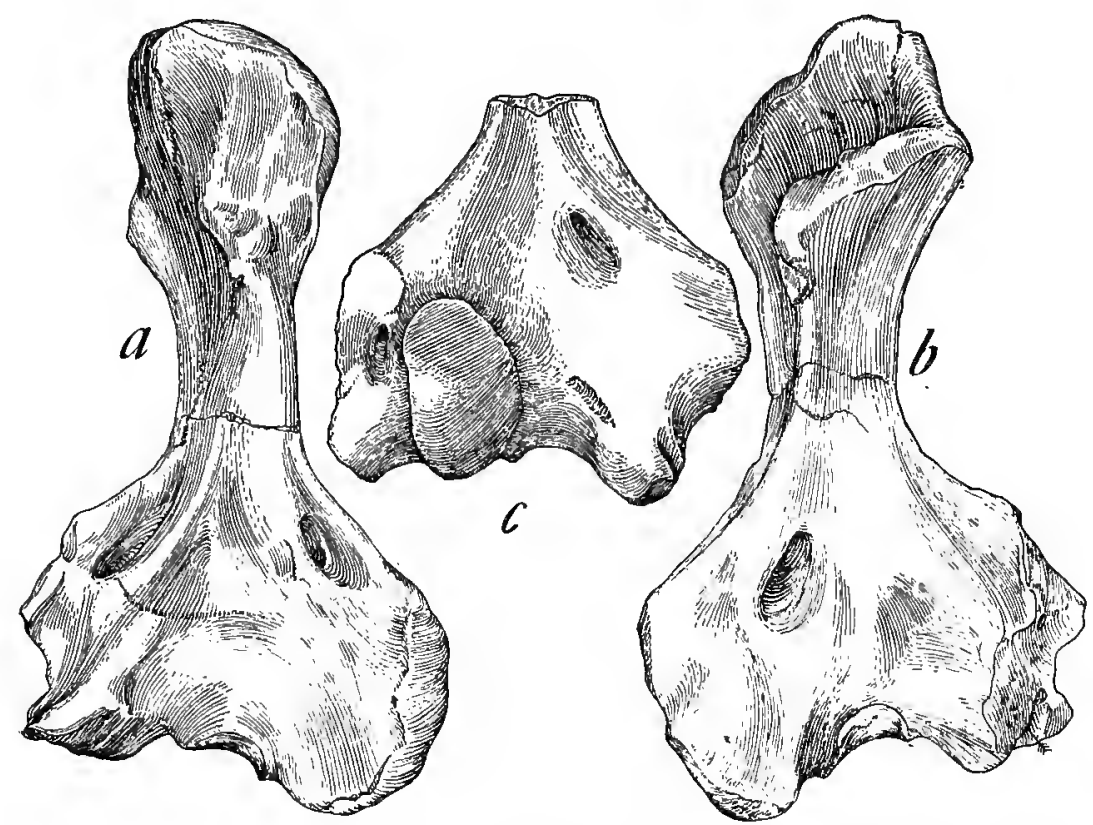

Fig. 50. - a, posterior view of left humerus of Edaphosaurus cruciger, showing ectepicondylar foramen. $\times 1 / 2$. No. 3333 .

$b$, anterior view of same humerus as shown in $A$.

$c$, anterior view of lower end of right humerus of Edaphosaurus cruciger, showing uncrushed condyle for radius and opening of ectepicondylar foramen. $\times 1 / 2$.

In publication No. I 8I of the Carnegie Institution the author noted the presence of an ectepicondylar foramen in the humerus of Edaphosaurus, p. 8I. The specimens had not been cleaned at that time and could not be figured. In figure 50 is shown the form of this bone with the position of the foramina. 

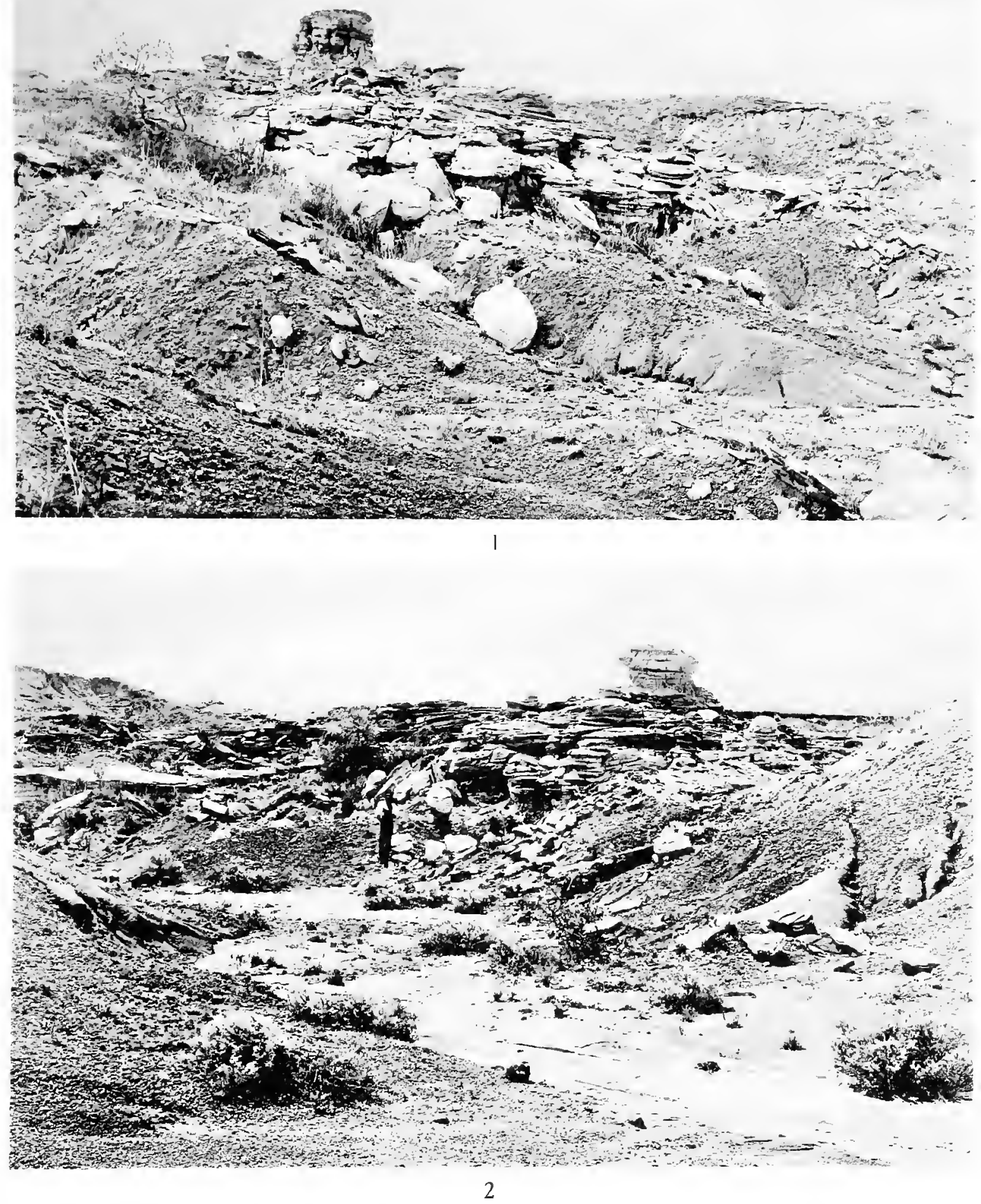

Fig. 1. Outcrop of Clear Fork sandstone, a few miles north of Craddocks Ranch, Baylor County. From the south.

Fig. 2. Same outcrop from the north. The lower part of the sandstone is light bluish, the upper part deep red and orange. The clays are deep red. This is an isolated mass of sandstone, probably the deposit of an old stream. 


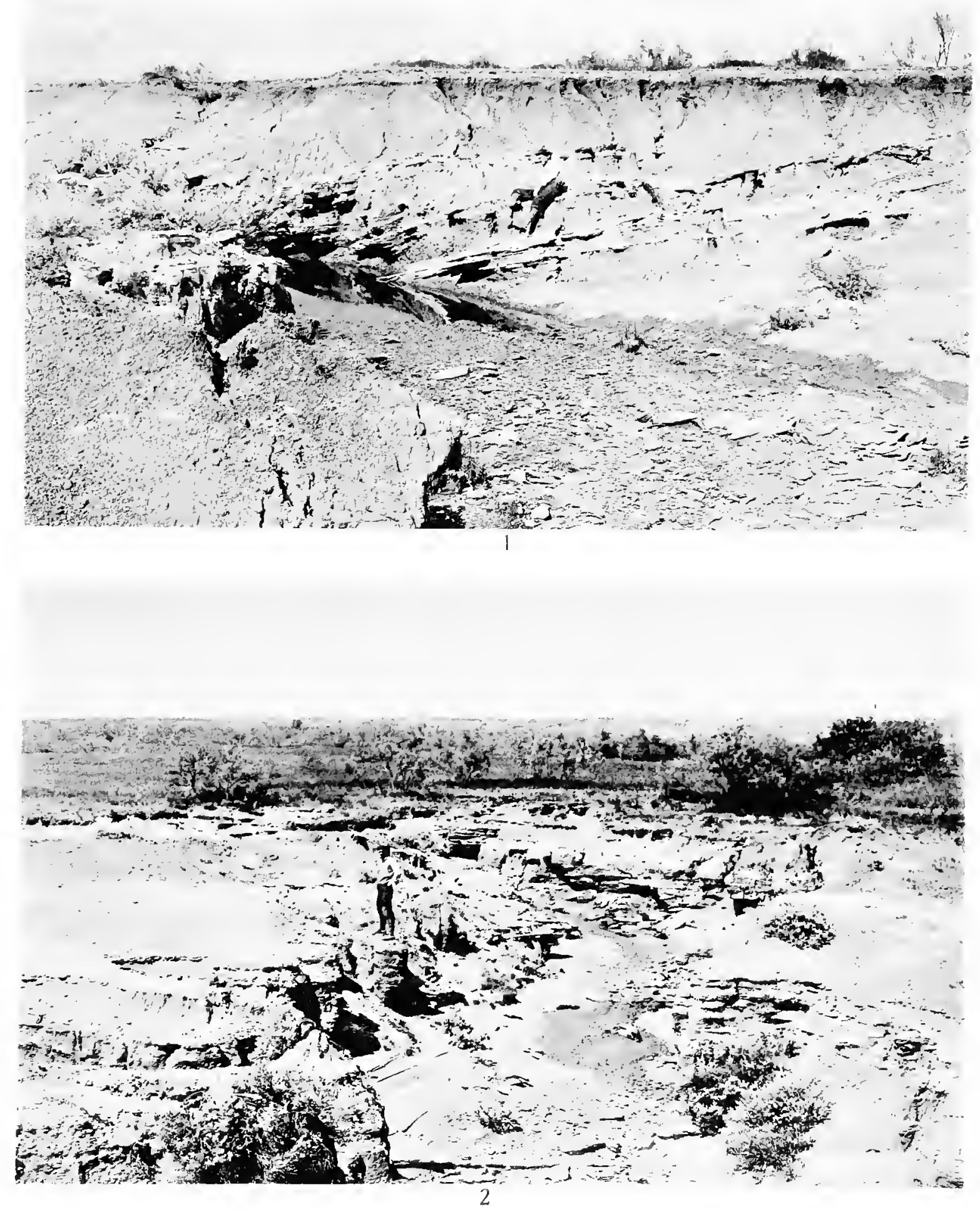

Fig. I. Clear Fork beds in Willbarger County near the Seymour-Vernon road. This illustrates the frequent playing out of the beds laterally.

Fig. 2. Clear Fork beds near the locality shown in fig 1. The clays are deep red and jointed, the sandstones light grey. Close to these localities are heavy conglomerate beds and in a small patch of clay the Lysorophus beds. 


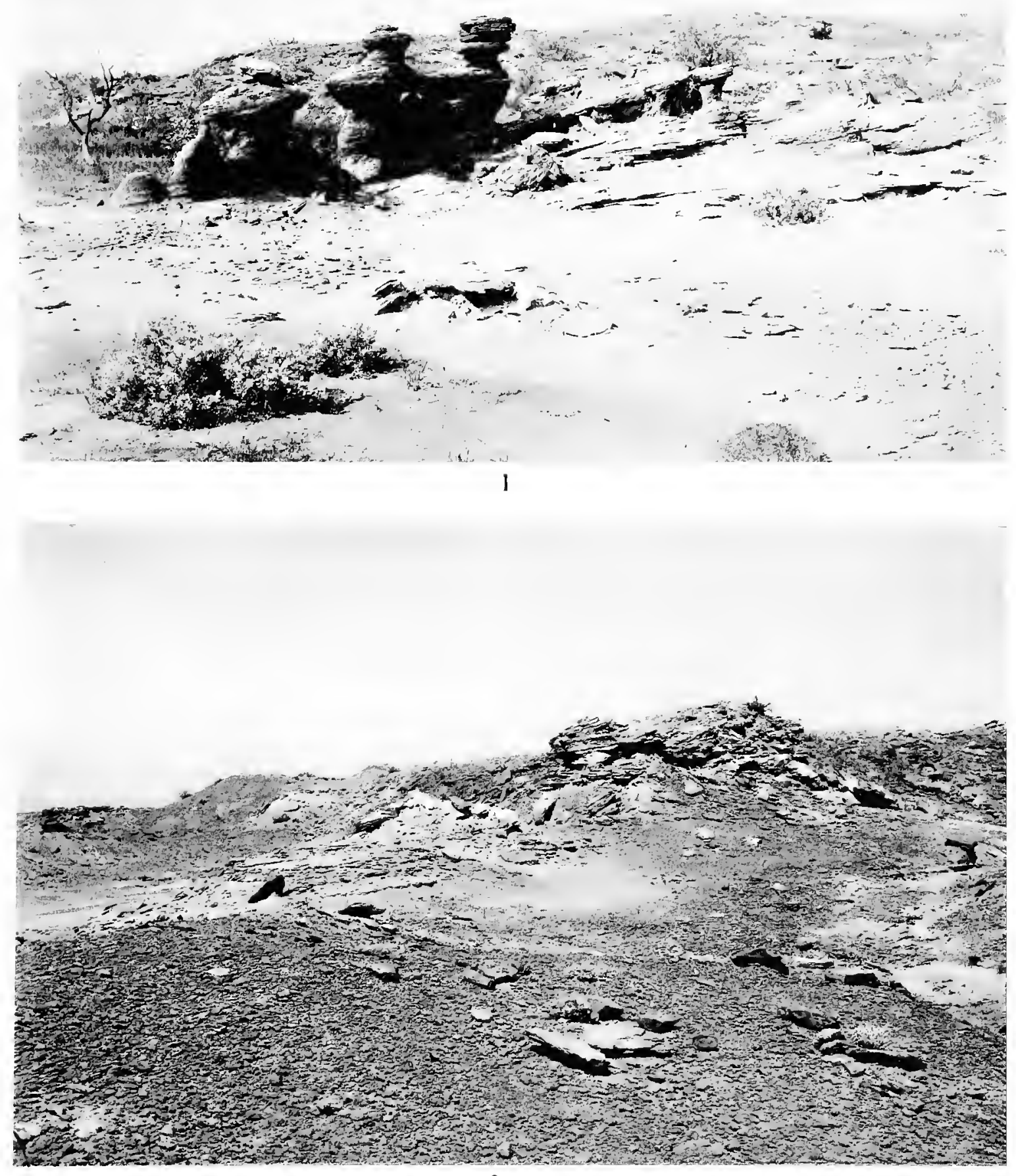

2

Fig. 1. Clear Fork sandstone north of Fulda, Baylor County. The dark upper part of the monument is deep red, the lower part light bluish grey. The unconformity of the beds is well shown.

Fig. 2. Shaly sandstone of the Clear Fork Formation, near the crossing of Godlin Creek on the Archer-Seymour road. Many fossils have come from this spot. 


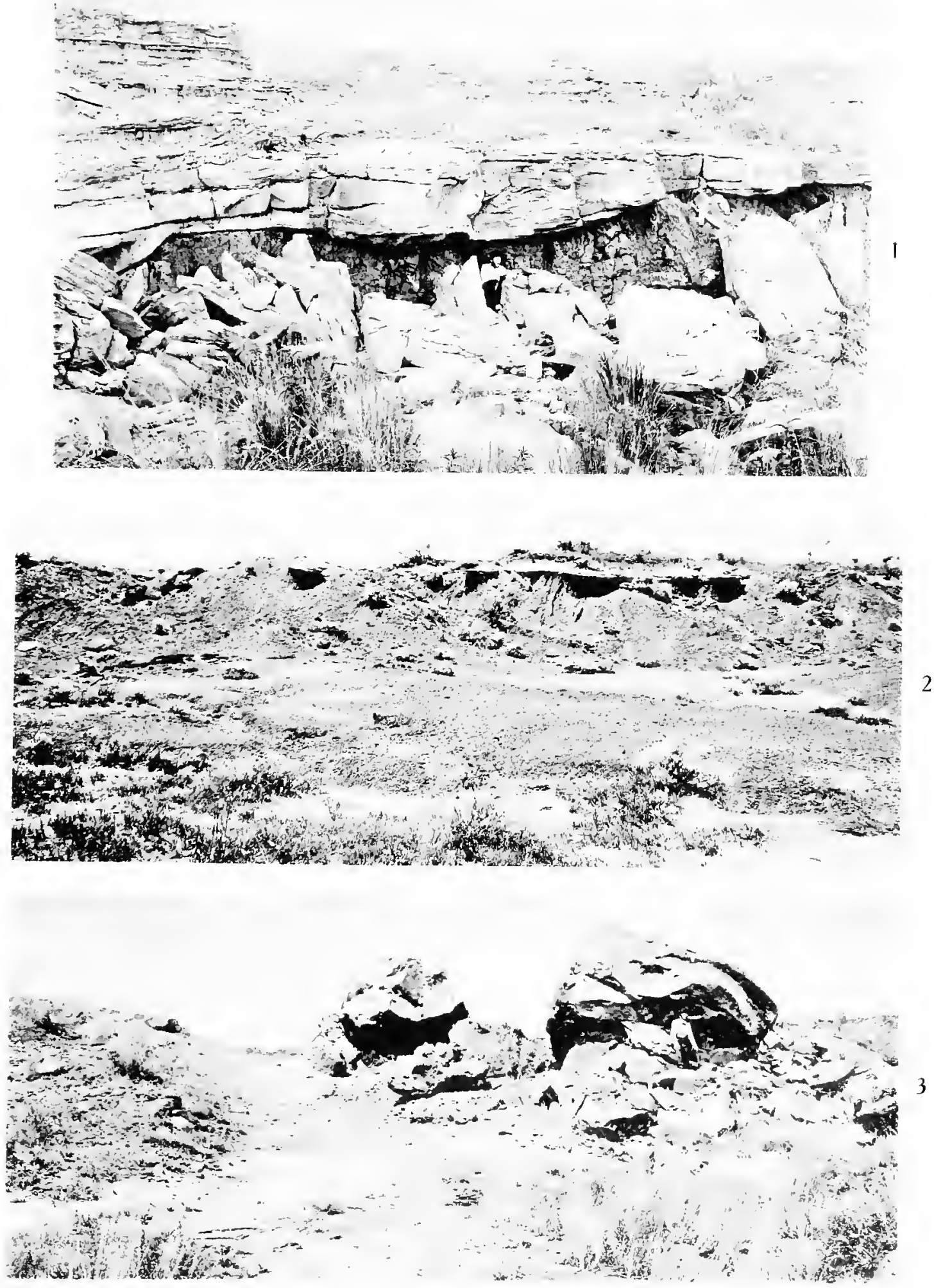

Fig. 1. Cross-section of an old river channel on Craddock's ranch.

Fig. 2. Typical exposure of Wichita Conglomerate on West Coffee Creek, Wilbarger County.

Fig. 3. Heavy sandstone of the Wichita Formation, just east of the Dundee Archer road and just south of the crossing of the Little Wichita River. A few rods to the west this layer becomes very thin and finally disappears. 


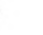



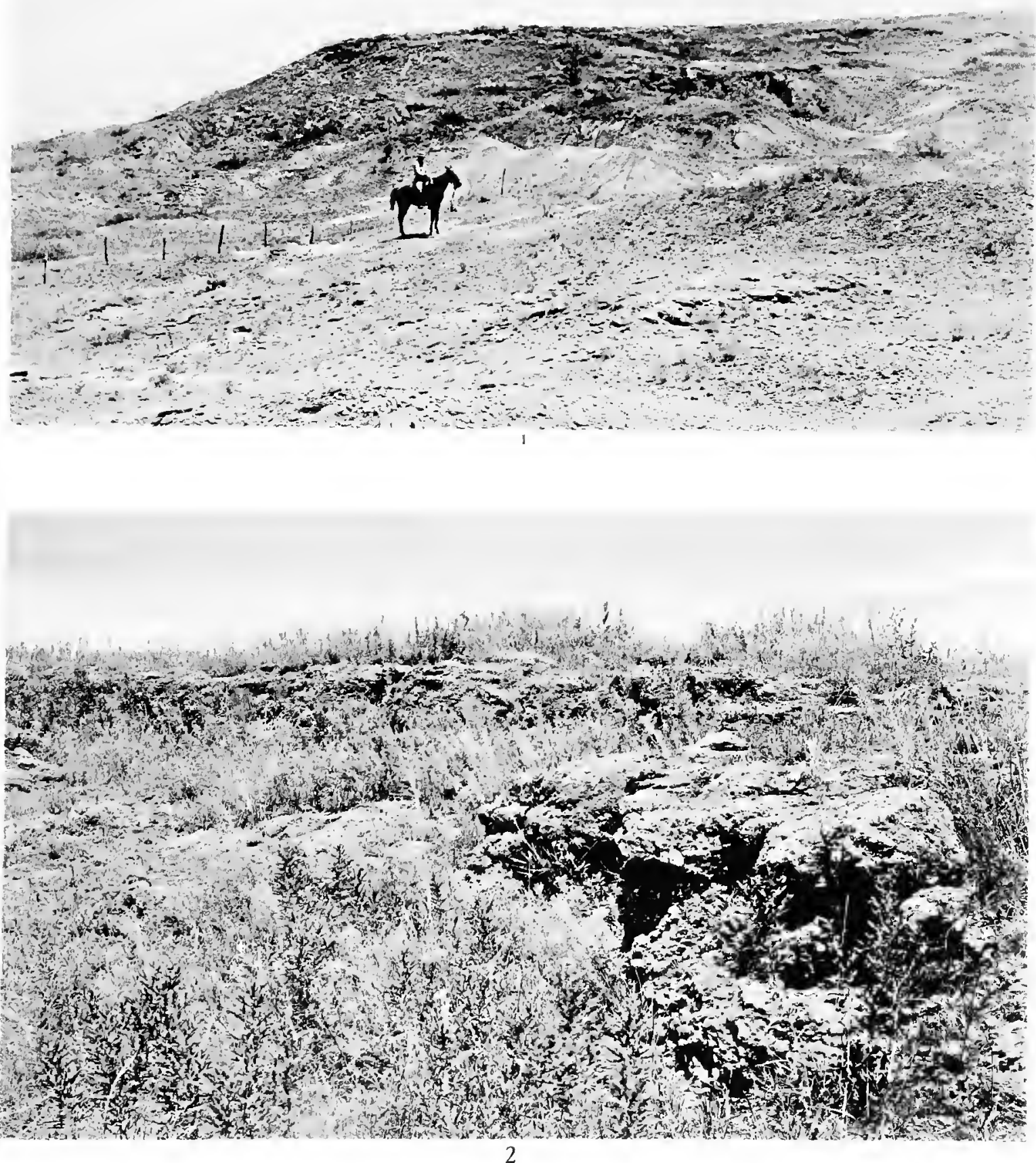

Fig. 1. Heavy conglomerate of Wichita age, 8 miles south of Dundee on the Dundee-Archer road.

Fig. 2. Detail of the conglomerate bed shown above. 


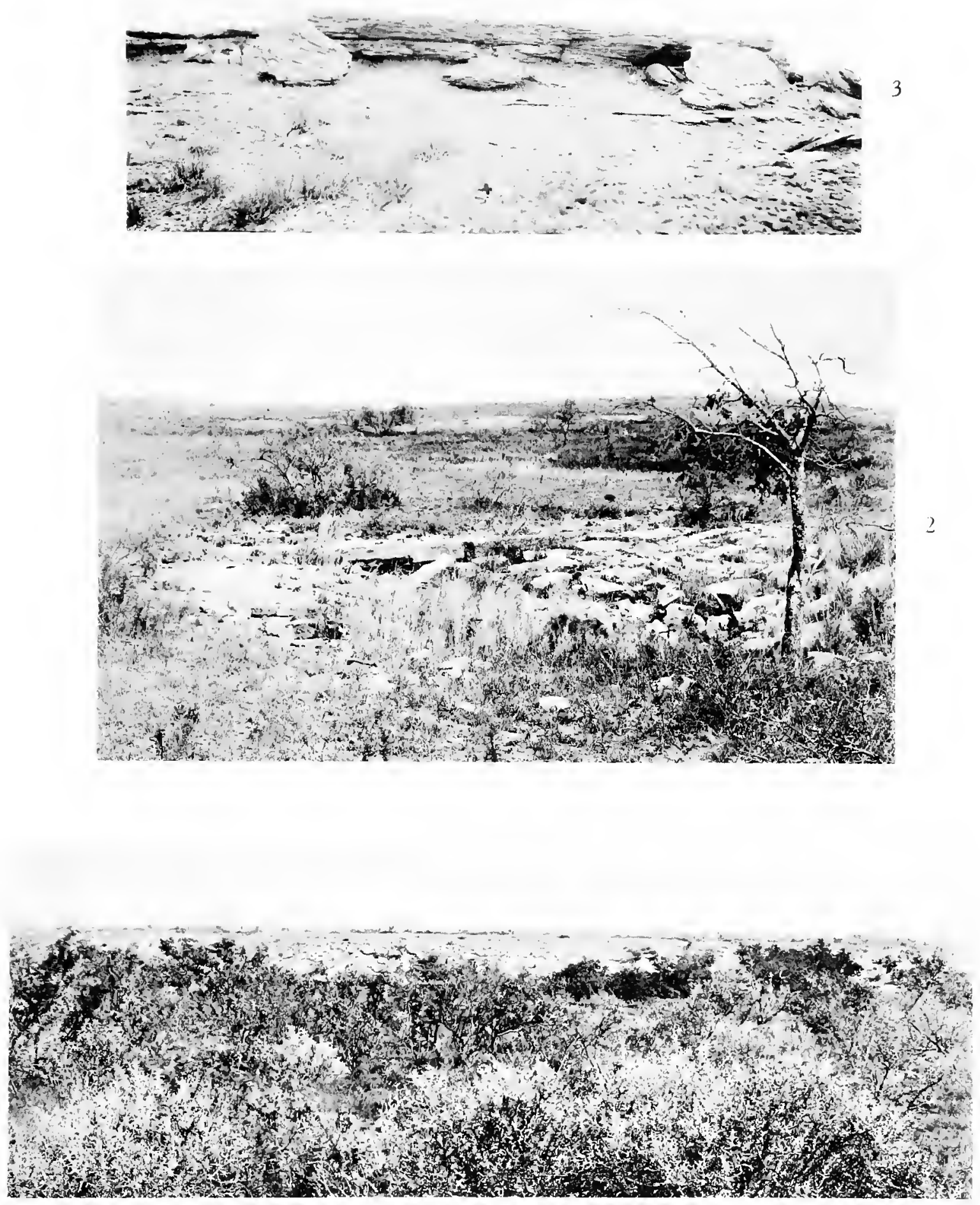

Fig. 1. Clear Fork limestone a few miles east of the Seymour-Vernon road and on the south bank of the Big Wichita River. The tendency to break into square blocks is well shown.

Fig. 2. Closer view of the same limestone.

Fig 3. Shaly sandstone of the Clear Fork Formation, south of Fulda. The outcrop is typical; it is near such localities that the bones are frequently found, they seem to indicate the edges of old current beds where carcasses or fragments which had been carried some distance were lodged. 
, 

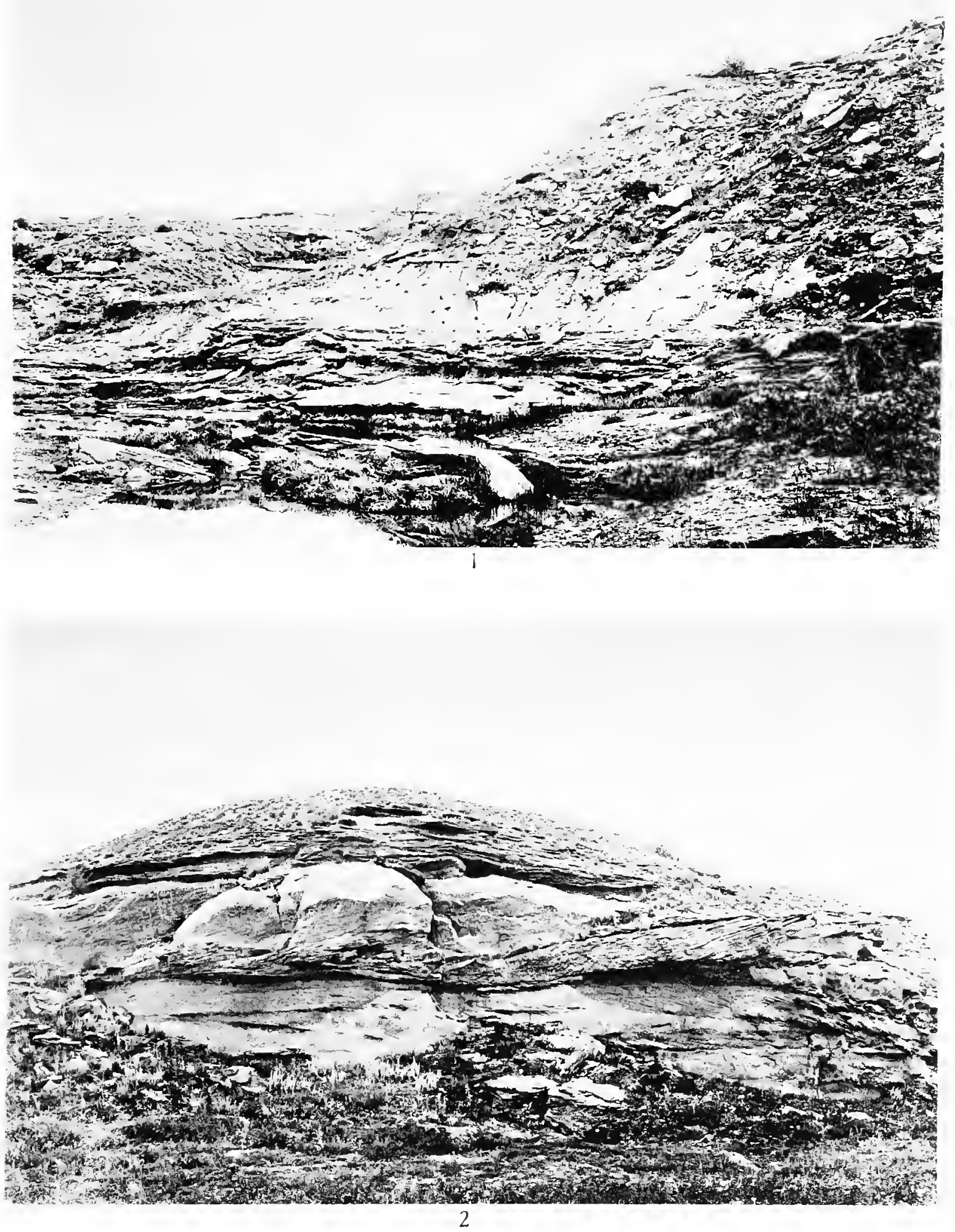

Fig. I. Triassic beds on San Juan Creek a few miles east of Tucumcari, New Mexico. The badly mixed character of the beds, so frequent in this region, is well shown.

Fig. 2. Near view, taken not far from the locality shown in figure 1. The pinching-out and cross-bedding is very clear. 


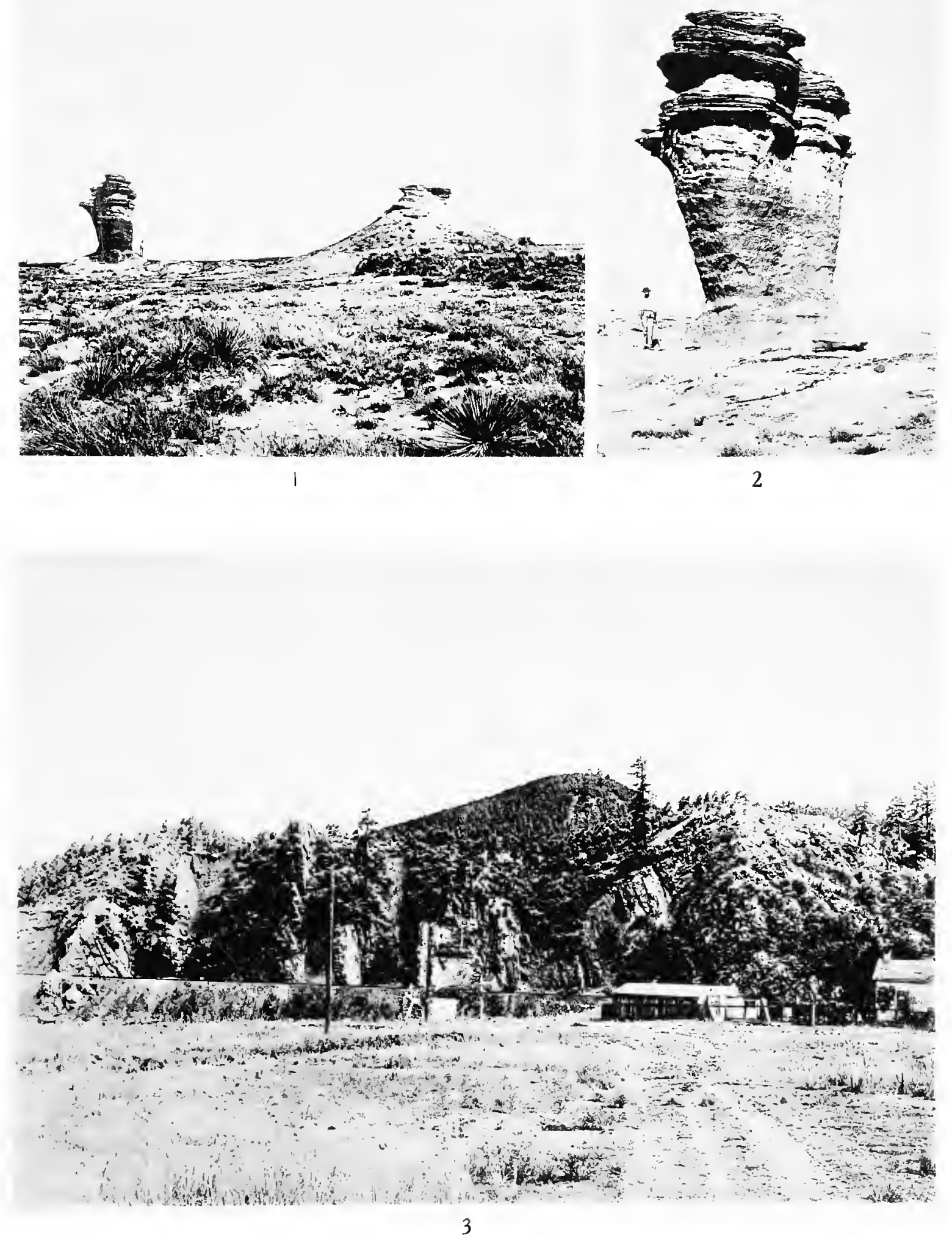

Fig. 1. Triassic Bad Lands a few miles east of Tucumcari, New Mexico.

Fig. 2. Nearer view of the large pillar shown in the previous figure. The cross-bedded sandstone is underlain by bluish sandy clay and this by a purple clay shading into red.

Fig. 3. Upturned Red Beds of Triassic age, on the south side of the valley at Las Vegas Hot Springs, New Mexico. The lower, western part of these Red Beds may possibly be Permo-Carboniferous. 


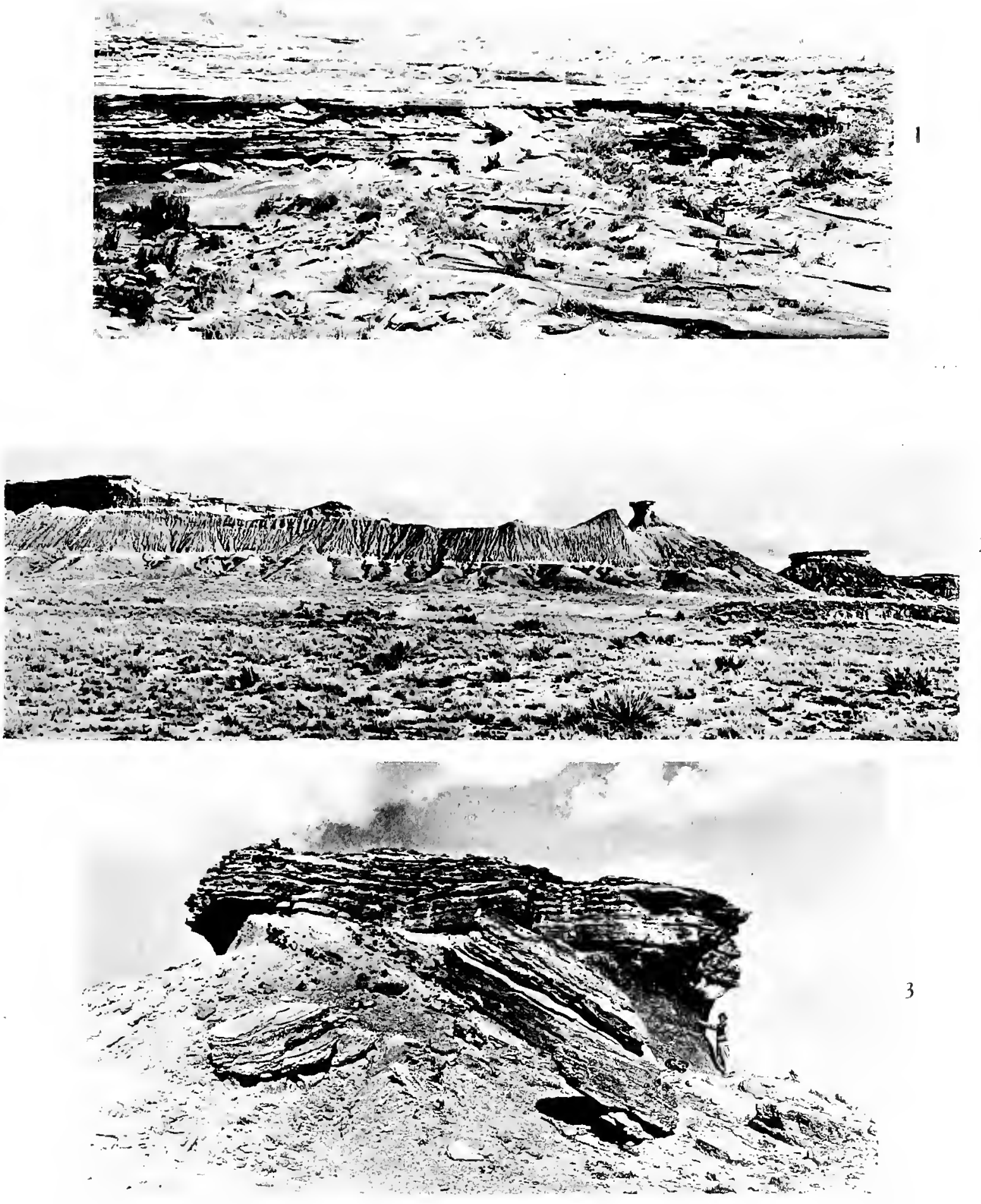

Fig. 1. Contact of the Double Mountain beds with the Dockum, Triassic, in Palo Blanco Canon, Dickens County, Texas. Line of contact is just above the tilted layer opposite the waist of the figure to the right.

Fig 2. Banded clays in the Bad Lands just east of Tucumcari, New Mexico.

Fig. 3. Nearer view in the same locality. The cross-bedded sandstone is underlain by bluish sandy clay, this by purple clay down to the hand of the man, and then deep red clay. 


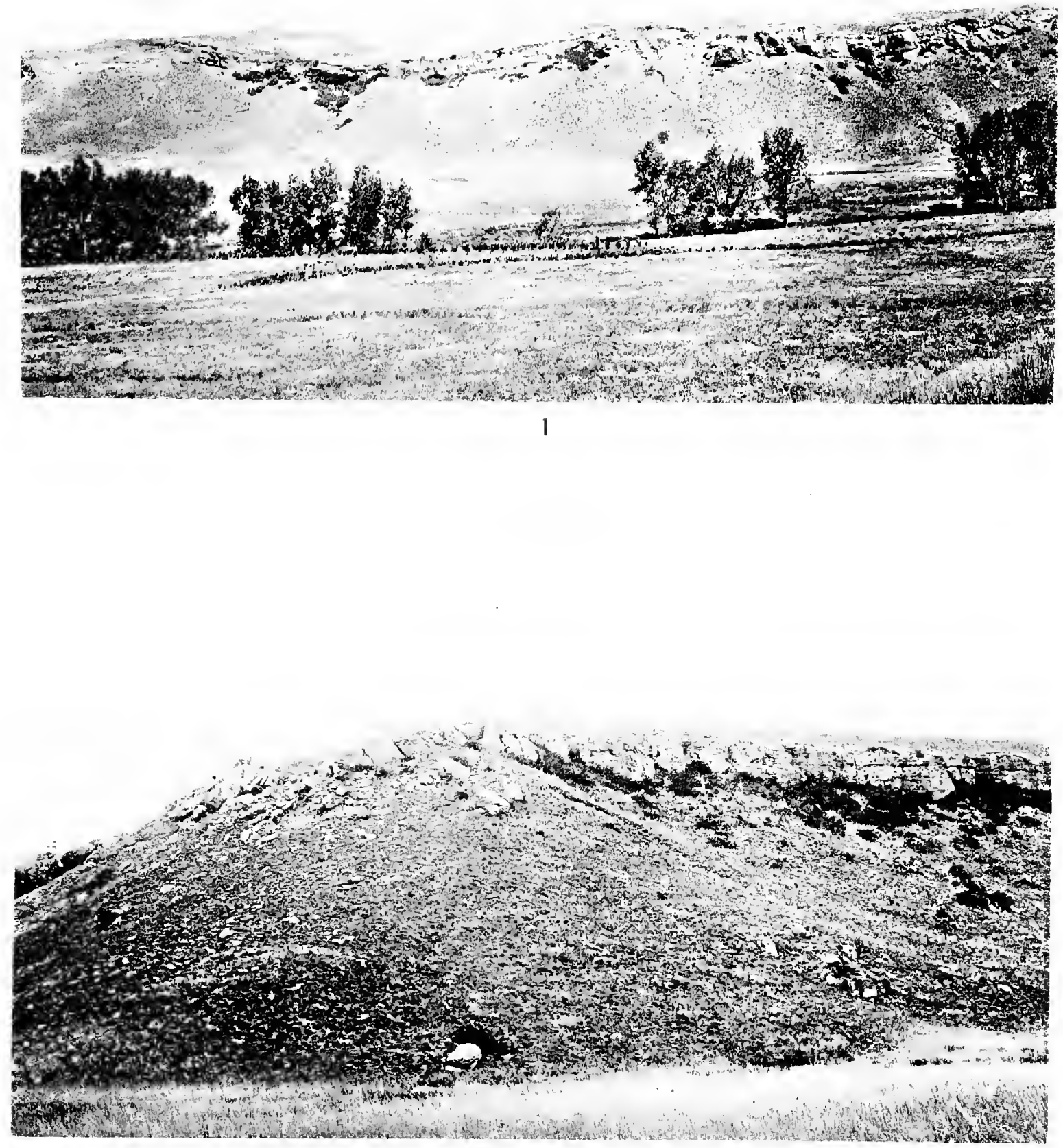

2

Fig. 1. Minnekata limestone lying on Opechee shale, Sand Creek, 3 miles west of Beulah, Wyoming.

Fig. 2. Minnekata limestone lying on Opechee shale in the west wall of Bear Gulch about 3 miles south of Beulah, Wyoming. 


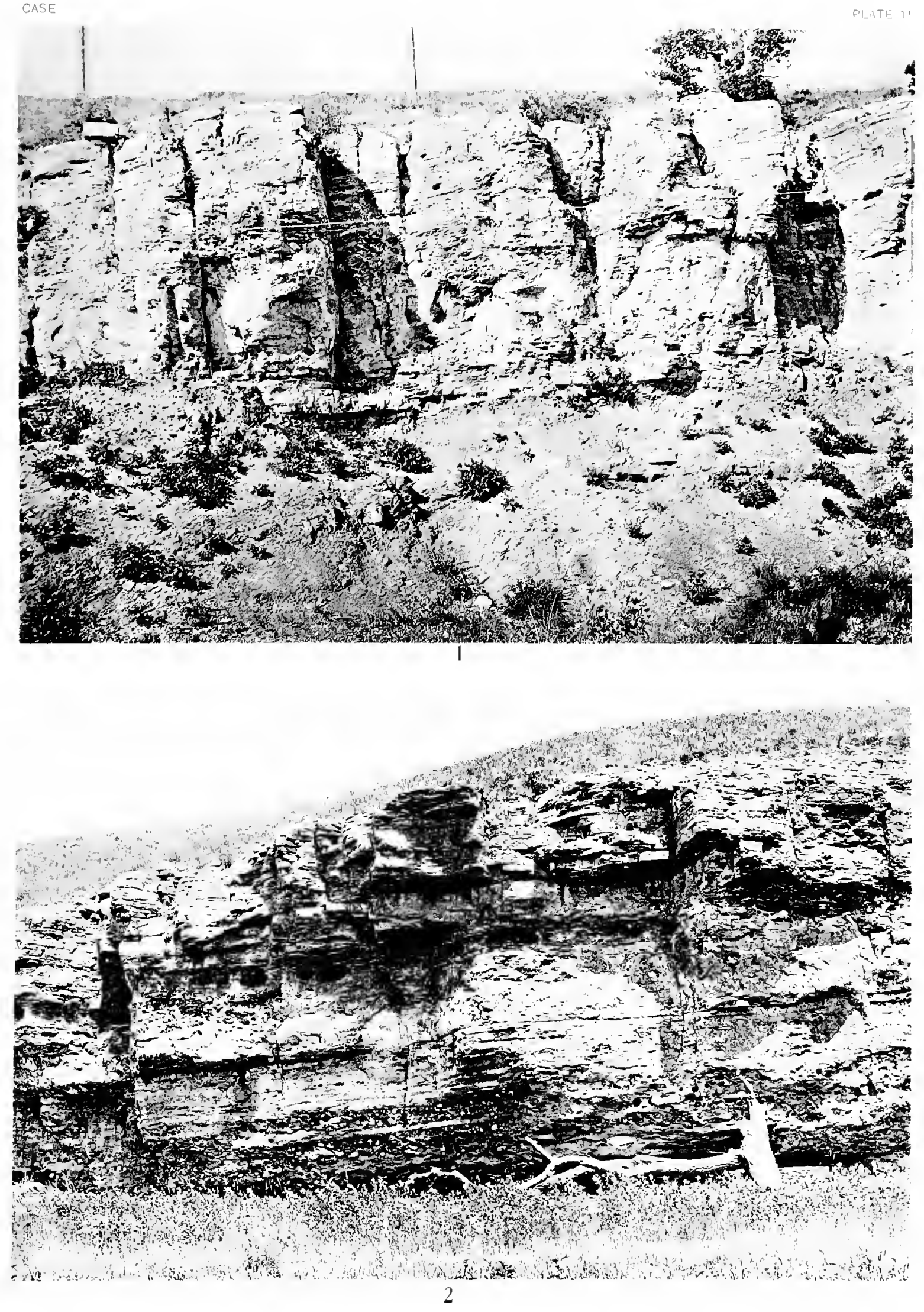

Fig. 1. Minnekata limestone underlain by Opechee clays, on the railroad in the south limits of Spearfish, South Dakota. The clay immediately below the sandstone is deep purple, below it becomes deep red.

Fig. 2. Minnekata limestone, about one mile south of Beulah, Wyoming, on the banks of Sand Creek. 


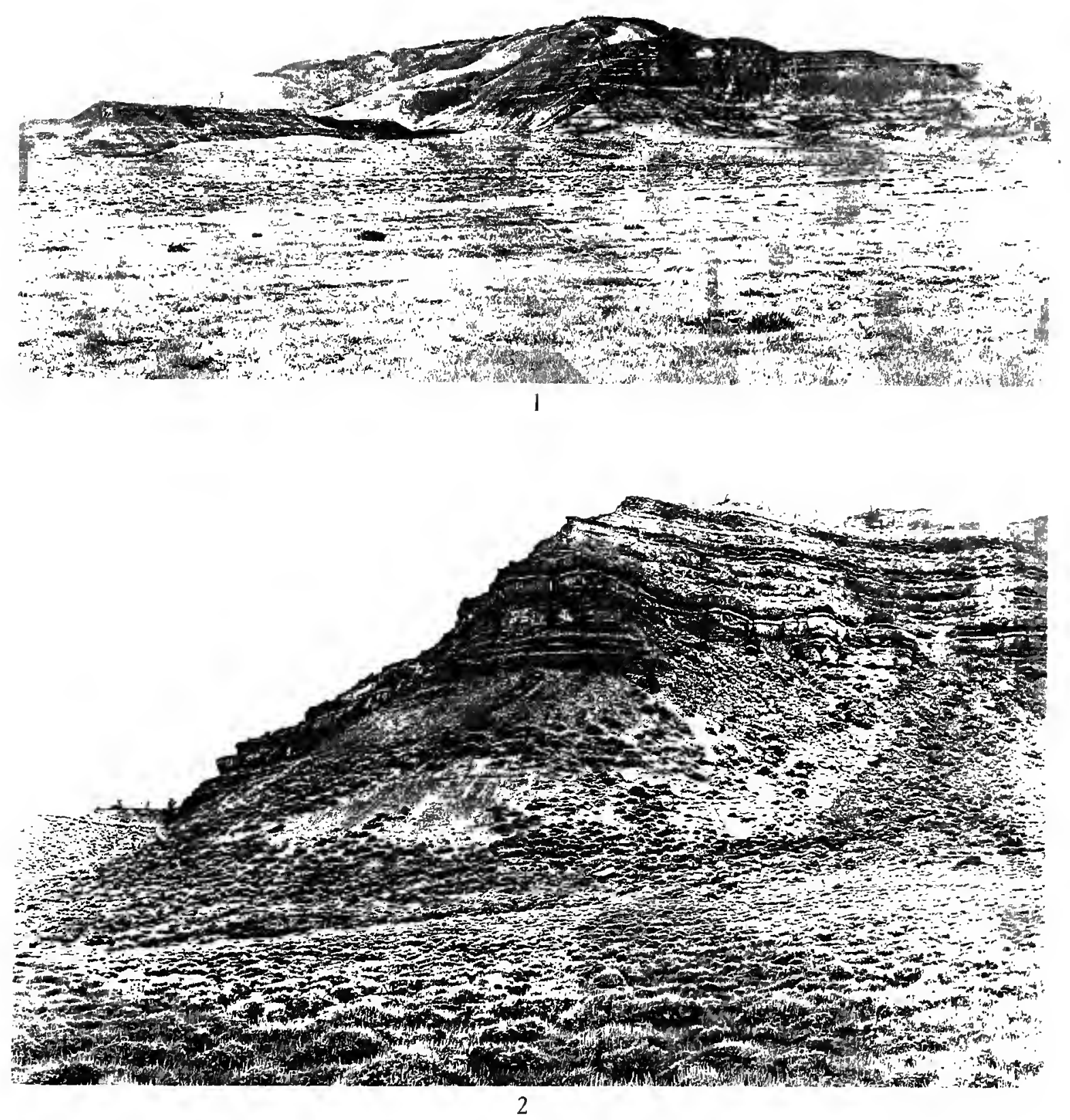

Fig. 1. Red Mountain south of Laramie, Wyoming. View from the north, showing full extent of the Red Beds, Cretaceous in the foreground. Knight's locality for invertebrate fossils is near the middle of low hill in the middle of the picture, just above where the white layers stop.

Fig 2. South side of Red Mountain, south of Laramie, Wyoming, showing the Chugwater (?) red shale and sandstone. 


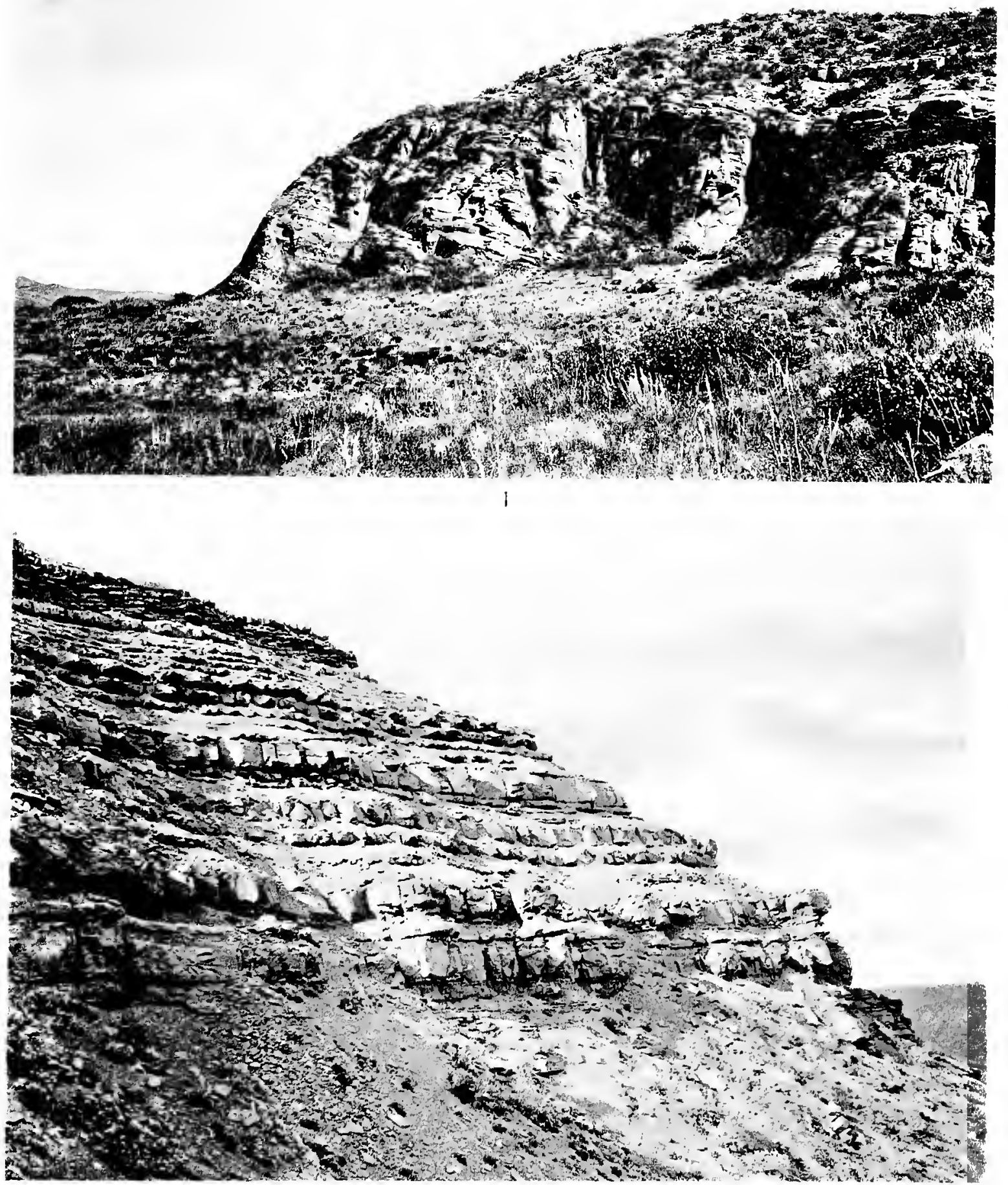

2

Fig. 1. Pinkish, massive beds of sandstone at the top of the Lykins formation, about 2 miles directly east of Owl Canon, Colorado.

Fig. 2. Upper part of the Red Beds, Chugwater (?), on the south face of Red Mountain, south of Laramie, Wyoming. 


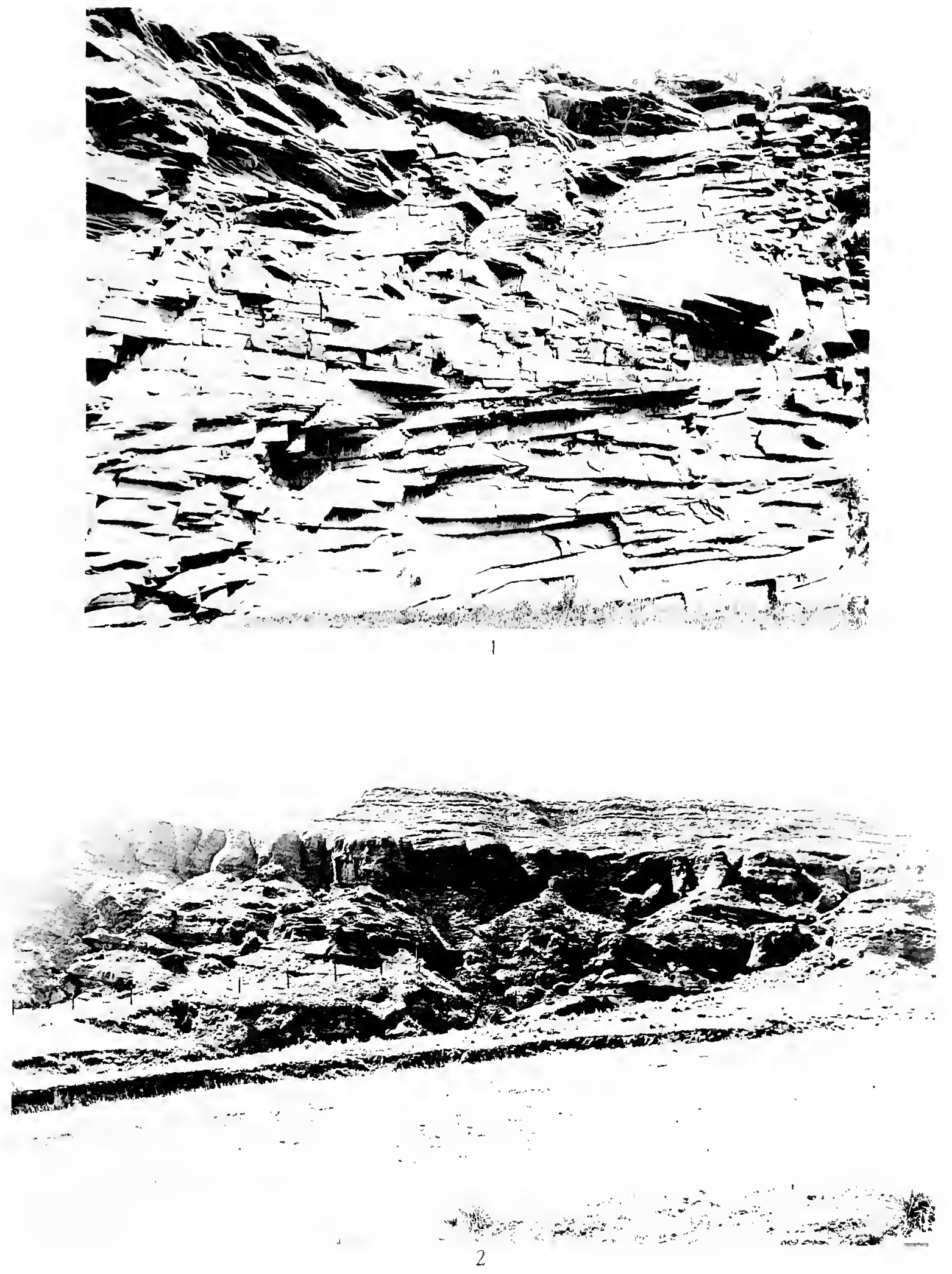

Fig. 1. Near view of the "cross-bedded sandstone" Lyons (?), near Stout, Colorado.

Fig. 2. Massive red sandstone of the Spearfish Formation, about a mile northwest of Beulah, Wyoming. 


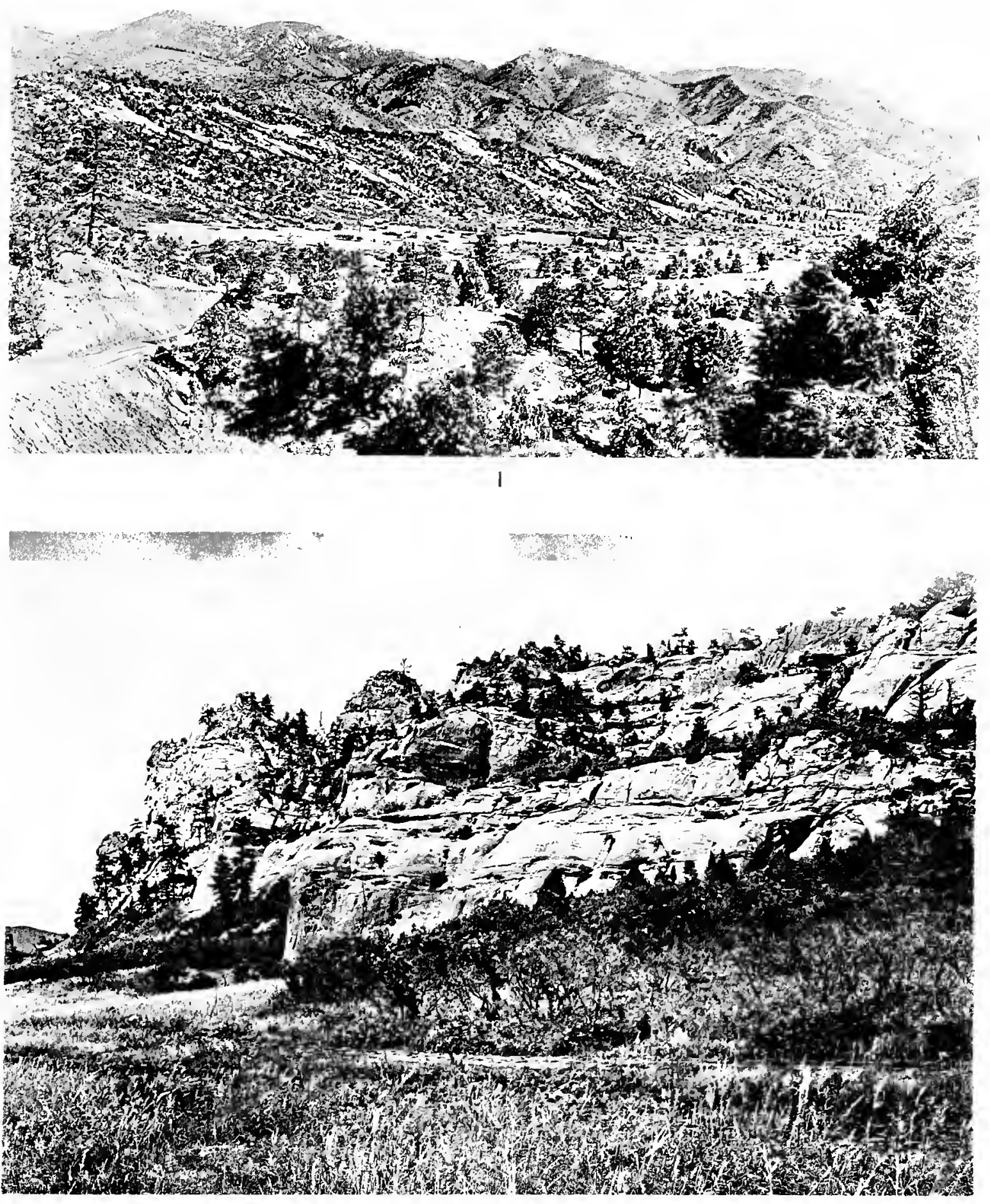

2

Fig. 1. Red Sandstone and red clay beds of the lower Wyoming, about 16 miles south of Colorado Springs on the Canon City road.

Fig. 2. Massive red sandstone of the lower Wyoming, Perry Park, Colorado. 



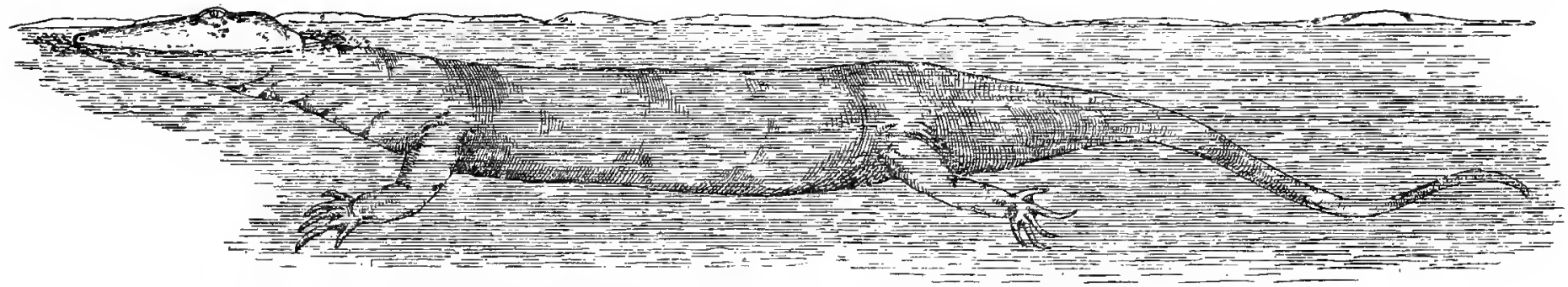

Frg. 1.--Restoration of Cricotus heteroclitus Cope. About one-sixth natural size of an average specimen; other specimens were considerably larger. The picture gives perhaps rather too strong a suggestion of the aquatic characters; the animal should be represented as living in a river, to be on the safe side.

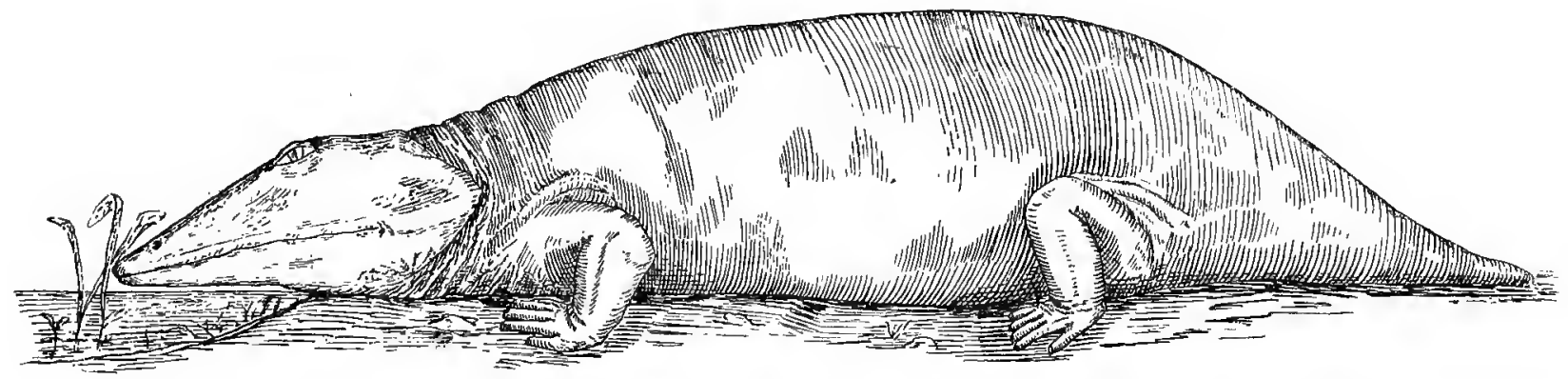

FIG. 2.- Restoration of Eryops megacephalus Cope. About one-tenth natural size of an average specimen. The tail is represented rather short in consonance with the author's ideas of the creatures.

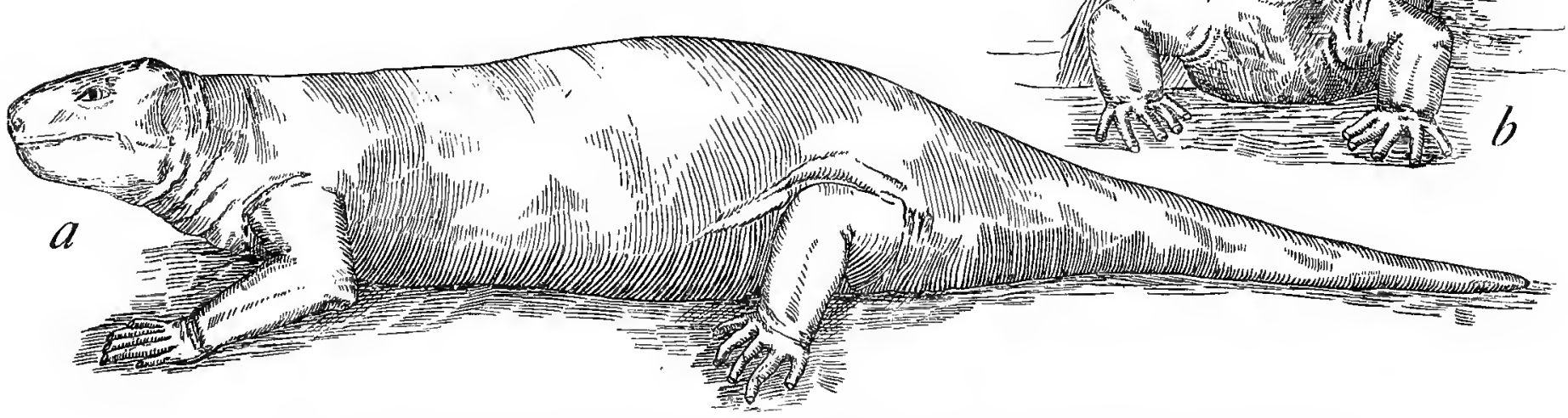

Frg. 3.- $a$, Restoration of Diadectes phaseolinus Cope, about one-tenth natural size; $b$, anterior view of same animal. 


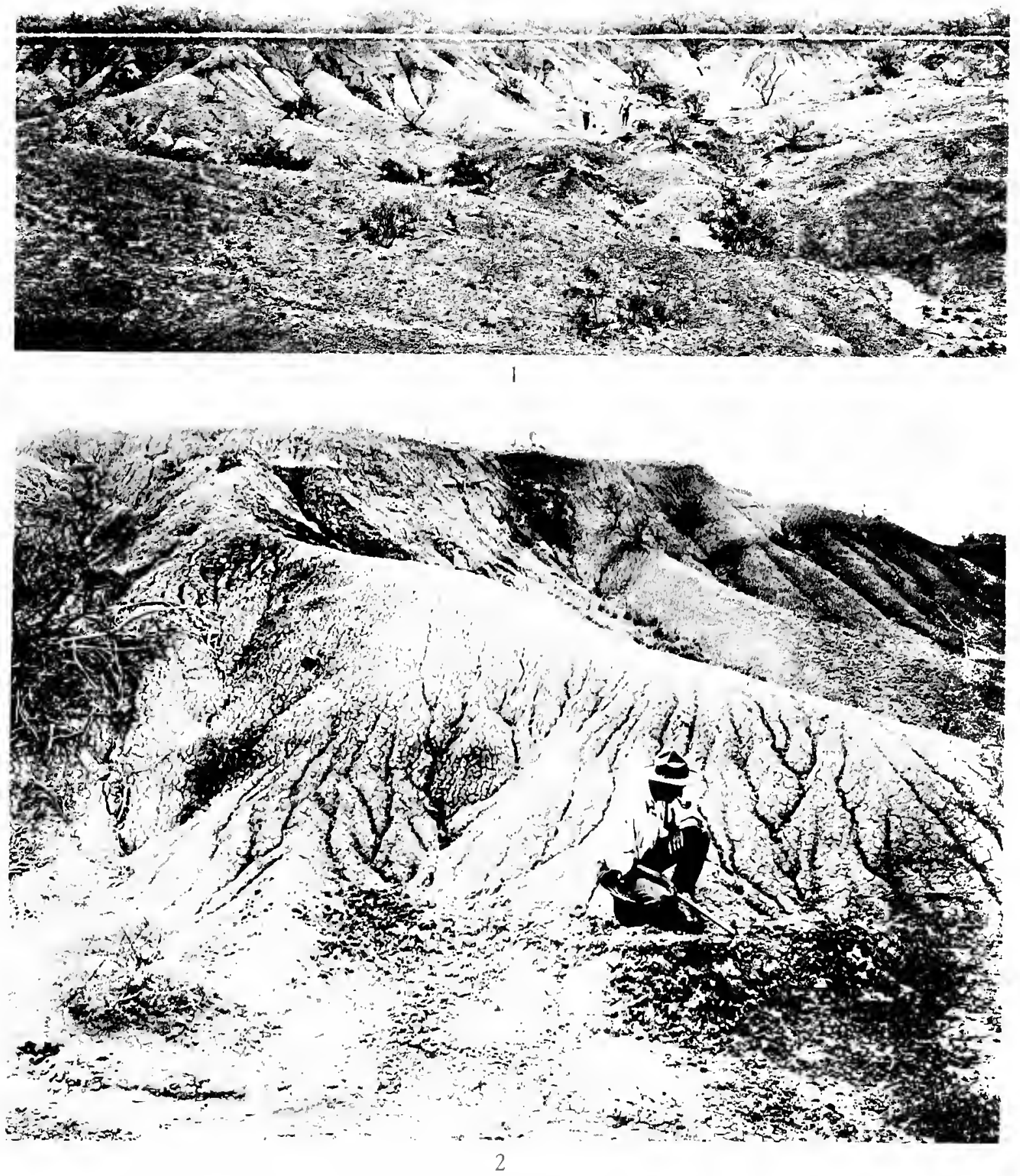

Fig. 1. Locality of Brier Creek Bone Bed in Archer County, Texas. The material is a light grey clay. The figures stand upon the outcrop of the bones which lay in part upon a thin bed of conglomerate composed of small pebbles.

Fig. 2. Nearer view of the bone bed before it was excavated. Fragments below the figure are all bones and parts of bones. 



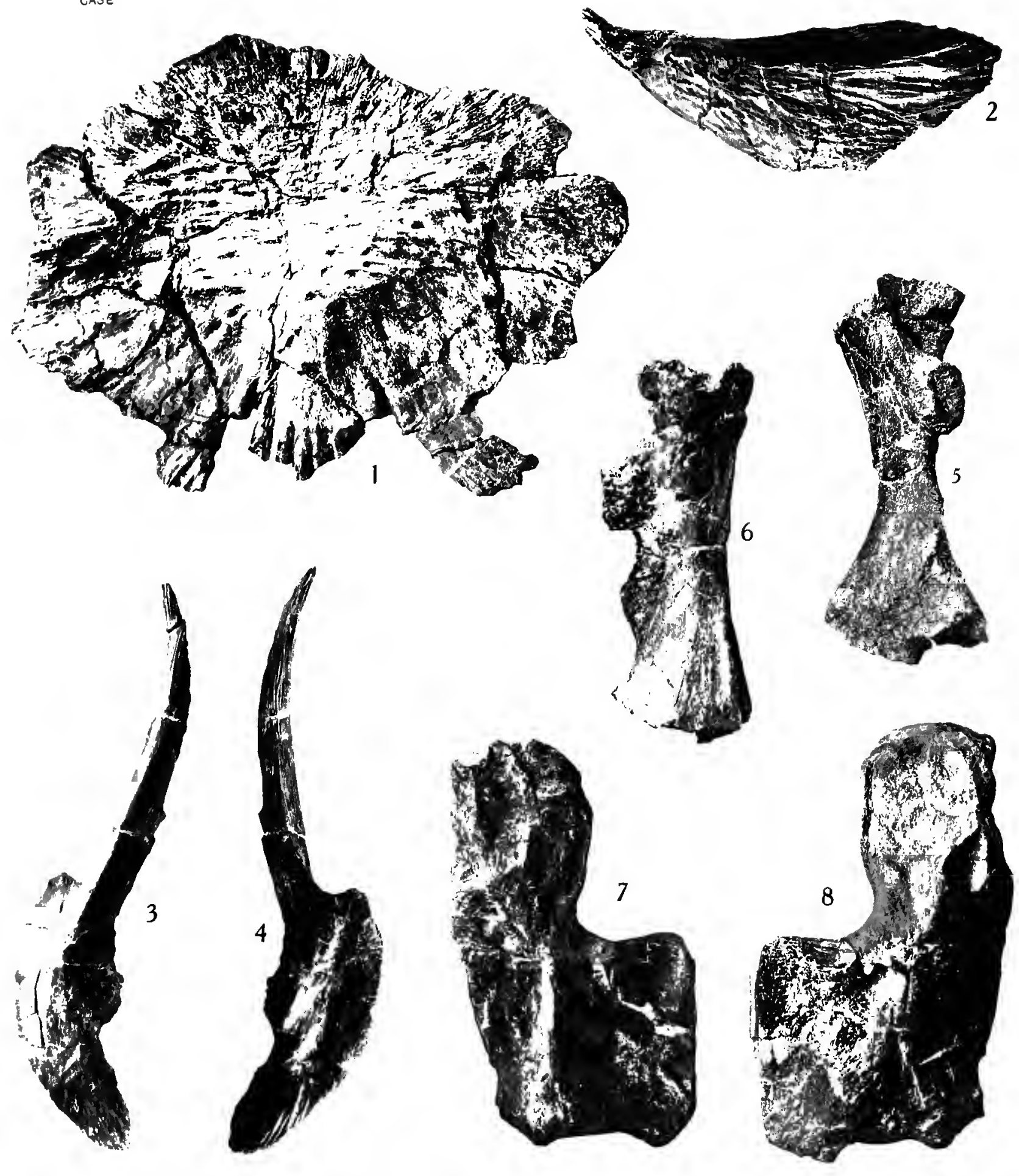

Fig. 1. Interclavicle of Eryops, showing sculpture. No. 3406. $\times 0.93$.

Fig. 2. Proximal end of left clavicle of Eryops, showing sculpture. No. $3385 . \times 0.5$.

Fig. 3. Outer face of right cleithrum of Eryops. No. 3408. $\times 0.3$.

Fig. 4. Inner face of same. $\times 0.3$.

Fig. 5. Lower face of femur of an unnamed amphibian. No. 3295. $\times 0.5$.

Fig. 6. Lateral face of same. $\times 0.5$.

Fig. 7. Upper face of left humerus of Archeria robinsoni. No. $3246 . \quad \times 0.5$.

- Fig. 8. Lower face of same. $\times 0.5$. 


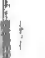



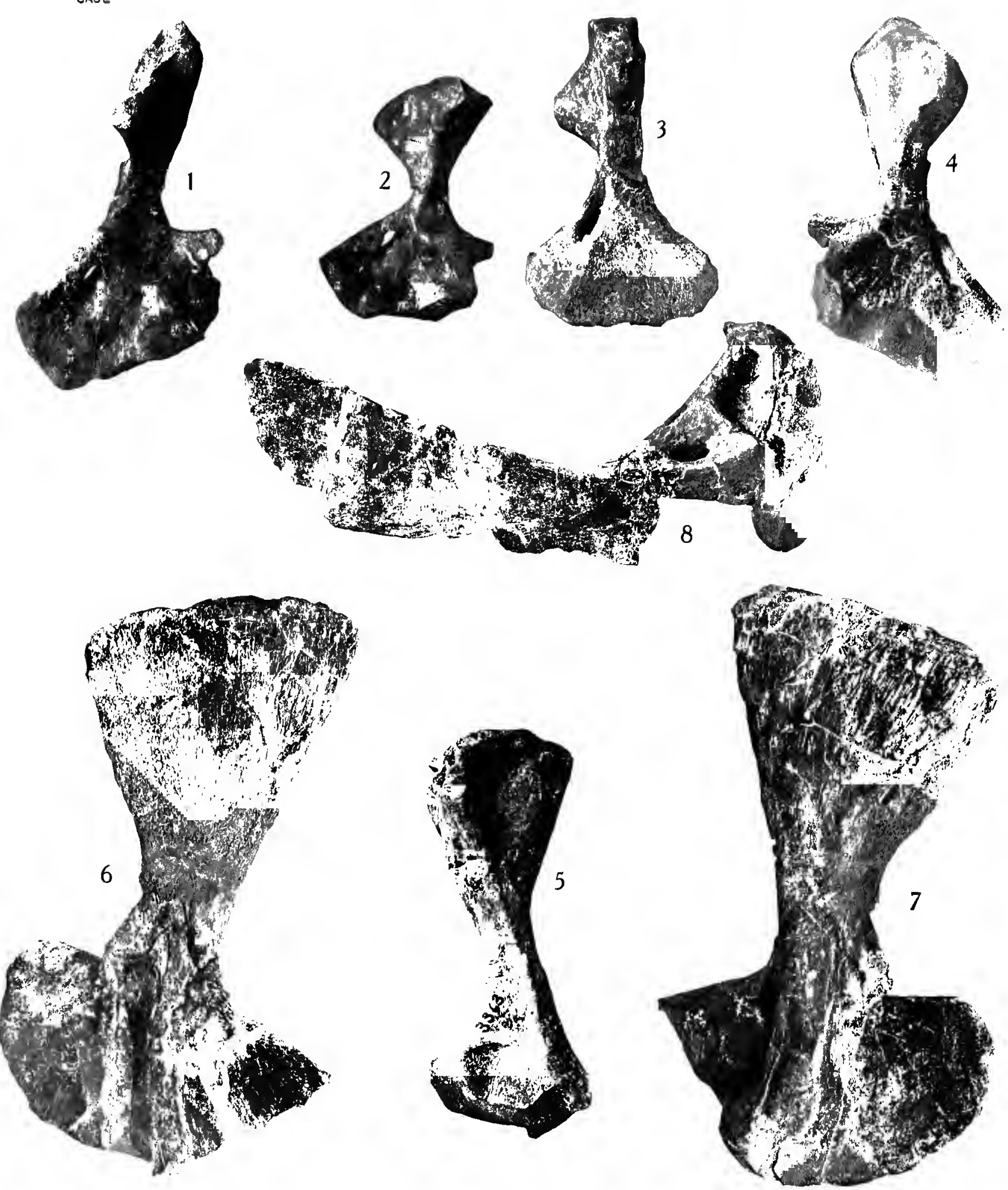

Fig. 1. Lower face of humerus of an unnamed reptile. No. 3354. $\times 0.5$.

Fig. 2. Lower face of humerus of a smaller specimen of same. $\times 0.7$.

Fig. 3. Upper face of a specimen of same. $\times 0.7$.

Fig. 4. Upper face of same humerus shown in fig. 1. $\times 0.5$.

Fig. 5. Lower face of left femur of unnamed reptile. No. 3363. $\times 0.9$.

Fig. 6. Inner face of right scapula of unnamed reptile. No. $3437 . \times 0.6$.

Fig. 7. Outer face of same. $\times 0.6$.

Fig. 8. Outer face of left scapula of unnamed reptile. No. 3439. $\times 0.3$. 






